Aves/Swai 
Mus Nat Hist.

\section{N N}

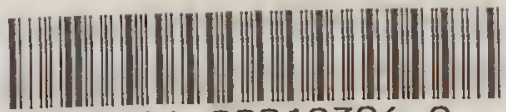

BIBLIOTHEEK 


Hus Nat $\mathrm{P}_{i}$ t

$\frac{280}{42}$

THE

CABINET CYCLOPs mEDIA. 
JANDON :

printed by A. Spotrisivoouk, New-Strect-Squire. 


\title{
CABINET CYCLOPADIA.
}

\author{
CONDUCTED BY THE
}

REV. DIONYSIUS LARDNEI, LL.D. F. R.S. L. \& E. M.R.I.A. F.R.A.S. F.L.S, F.Z.S. Hon, F.C.P.S. \&e. \&c.

ASSISTED BY

EMINFNT LITERARY AND SCIENTIFIC MEN.

\section{ఇatural 背igtorn.}

ON

THE NATURAL HISTORY AND CLASSIFICATION

OF

B I R D S.

RY

WILLIAM SWAINSON, A.C.G. F. R.S.

VICE-PRRSIDENT OF THE ORNITHOLOGICAL SOCIETX, RTC.

VOL. II.

\section{LON DON :}

PRINTED FOR

LONGMAN, REES, ORME, BROWN, GREEN, \& LONGMAN, PATERNOSTER-ROW;

AND JOHN TAYLOR,

UPPER GOWER STRERT.

1837. 
NATURE IS $\Lambda$ BOOK WRITTEN ON BOTH SIDES, WITHIN AND WITHOUT, IN WHICH THE FINGER OF GOD IS CLEARLY VISIRLE - A SPECIES OF HOLY WRIT IN A BODILY FORI -A GLORIOUS PANEGYRIC, AS IT WERE, ON GOD'S OMNIPOTENCE, EXPRESSED IN THE MOST VIVID SYMHOLS. THF OUTRR PART OF TIIS SACRED VOLUME ATTESTS TIIF SUPREMR POWER, WISDOM, AND GOODNESS OF THE CREATOR, IN CHARACTERS TOO CLEAR AND LUMINOUS TO BE UNPERCEIVED OR MISREAI UY THE DULLEST OR THE MOST VITIATED EXE. THE INNER RAGES COMPRISE A STILX MORE GLORIOUS REVELATION, BUT THEIR LANGUAGE IS MORE MYSTERIOUS.

Fredtrick von Schlegel's Philos. of Life, p. $85.8 \mathrm{c}$. 
$-4+$ on $x=1$

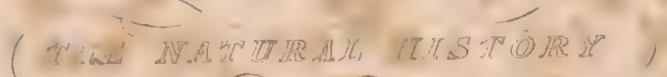

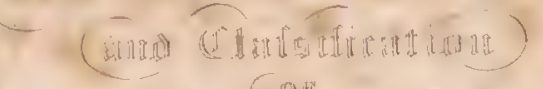

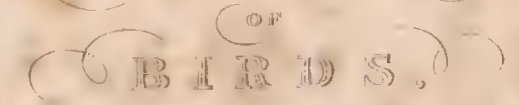

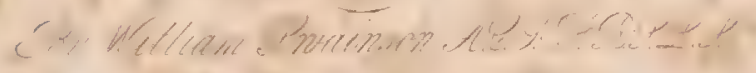

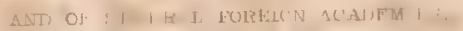

TY O I I III.

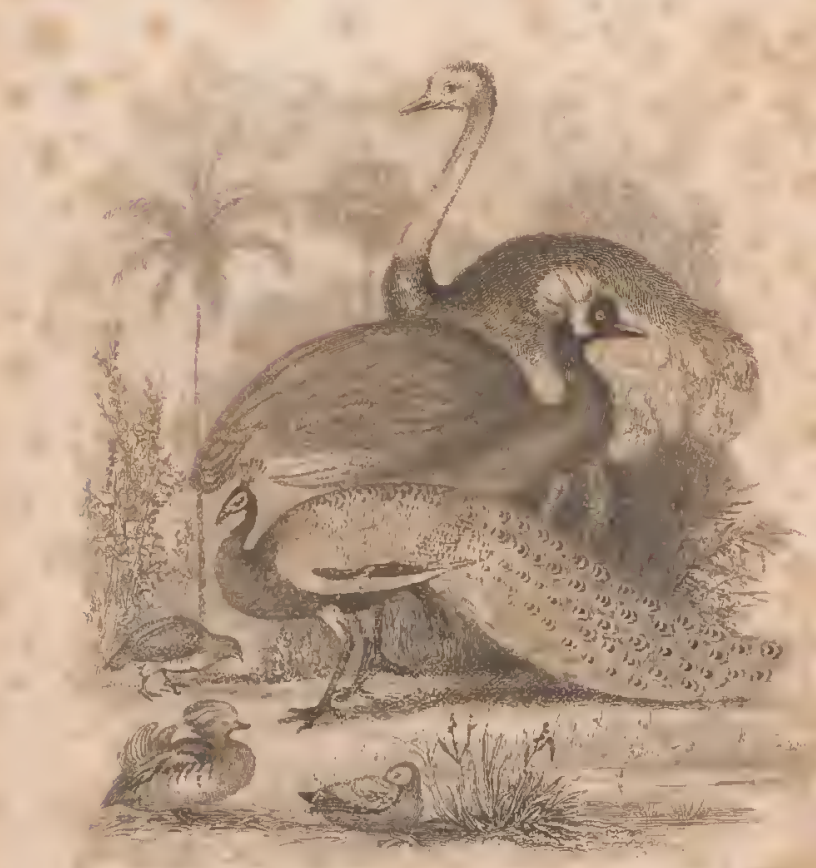

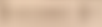


$\sqrt{2}+x^{2}$ 


\section{CONTENTS.}

\section{PART III.}

ON THE NATURAL HISTORY AND RELATLONS OF THE DIFEERENT ORDERS, TRIBES, AND FAMILIES OF BIRDS. ,

\section{CHAPTER III.}

On the Dentirostral Order, the Laniadæ, or Shrikes - - Page 1

\section{CHAP. IV.}

The Dentirostral Order continued. - The Merulida, or Thrushes - 17

CIIAP. $\mathrm{V}$.

The Dentirostral Order continued. - On the Sylviadæ, or Warblers - 38

\section{CHAP. VI.}

The Dentirostres continued. - The Family of Ampelide, or Chatterers 70

CHAP. VII.

The Dentirostres concluded. - On the Musicapidæ, or Fly.catchers - 78

CHAP. VIIL.

On the Conirostres, or Conic-billed Tribe

CHAP. IX.

On the Tribe of Scansores, or Climbing Birds - - - - 124

CIIAP. X.

On the Tribe of Tenuirostres, or Suctorial Birds _ _ _ _ 142 
CIIAP. XI.

On the Tribe of Fissirostres, or Swallow-like Birds _ _ Page 150

CHAP. XII.

On the Rasorial Order, or Gallinaceous Birds

CHAP. XIII.

On the Order of Grallatores, or Wading Birds - _ - 171

CHAP. XIV.

On the Order of Natatores, or Swimming Birds - _ _ - 183

\section{PART IV.}

STNOPSIS OF A NATURAL ARRANGEMENT OF BIRDS.

Introductory Remarks
Synopsis
Notes -


The Author has found it necessary to omit the "Description of New Species," which he had intended to introduce into the present Volume. These descriptions will, however, be inserted in a subsequent Volume of the Series of Natural History. 



\section{NATURAL HISTORY AND CLASSIFICATION}

$O F$

\section{B I R D S.}

\section{PART III. CONTINUED.}

ON THE NATURAL IISTORY AND RELATIONS OF THE DIFFERENT ORDERS, TRIBES, AND FAMILIES OF BInRs.

\section{CHAPTER III.}

ON THE DENTIROSTRAL ORDER, THE LANLADAE, OR SHRIKES.

(1.) THE conclusion of our last volume terminated our exposition of the relations of the Dentirostral Order. Our chief reason for entering so fully into that exposition, as we then stated, was to substantiate the three lealing principles upon which (as we maintainerl) the system of nature is foundel ; namely, 1 . The circular progress of affinities; 2. The theory of representation, by which the contents of one group aualogically represent the contents of all other groups; and, 3. The definitc nature of the principal types, contained in every circle. These are the chief propositions with which we commenced our exposition of the whole animal kingdom*, and which

- Classification of Animals, 241.

VOL. II. 
we are bound to make good, as best we can, in the details of all its classes and prominent groups: we are, in short, to bring our theory into practice, and - so far as our linited knowledge will permit - to substantiate this theory by analysis. If we fail in this, - if, in a group confessedly natural, our theory disturbs and disarranges the evident series of naturc, or fails to explain the principles of its minor variations, - we are quite willing it should be received with doubt and distrust. Or if our opponents, by any theory of their own, equally comprehensive, can explain and illustrate what this cannot do, we will then not only consent to abandon our propositions as untenable, but adopt any other more dernonstrative of the unity of Nature's laws. Until this, however, is done, or until something more philosophic is urged against us than the old reiterated assertion that "the time has not yet comc" "for these investigations, \&c. \&c., we may be allowed to preserve silence: these vague and qucrulous complaints, in truth, have emanated from those only who have hitherto done notling to place their names in the prominent ranks of science, and who may consequently be presumed inadequate judges upors matters they have not sufficiently studied. We may be allowed to remind such objectors, as well as to urge upon all naturalists, that it is both umphilosophic and unfair to pronounce upon the value of any theory, until the whole of the facts intended to prove its truth are laid before them. We have, in the onset, clearly stated our propositions, and declared that our proofs would follow, as we successively brought under examination erery class of the animal kingdom. When the whole of these are gone through, and the Cablivet of Natural HisTony is completed, it will then be the proper time to determine whether our views of the general laws of nature are erroneous, whether we have not sufficient facts before us, or whether we are to wait, as these writers insinuate, (perhaps another century) until our knowledge of natural objects - almost overwhelming as it now is-

* Magazine of Zoology and Botany, i. p. 20, \&ce. 
becomes more extensive, or rather, from the want of some generalising principle of classification-more confused. Why the philosophy of Zoology is to stand still, while that of all other sciences is rapidly advancing, and consequently simplifying, and why we are not to generalise that which we know, from a fear of there existing things which we do not, and probably never skall, know, are questions almost too absurd to be asked.

(2.) The limits of one volume (for our first is almost entirely an introduction) are totally inadequate to that ample elucidation of the natural classification of birds which the professel ornithologist would desire, particularly when the arrangement we sluall here propose, from its novelty, would seem to require so much explanation. We possess sufficient materials, indeed, for filling four such volumes as this; but the original portion devoted to Ornithology having been already exceeded, there remains no other plan to bc followed than taking a rapid survey of the chief divisions, dwelling occasionally upon such as require more than ortinary elucidlation, and giving, in some instances only, examples of that extended analysis which becomes necessary to full demonstration, and by which the circular groups we shall here indicate may be better understood.

(3.) The rapacious habits of the LANIAD $E$, or shrikes, are known to every one acquainted with our native birds; and the comparisons that have been drawn between them and the falcons are no less true in fact, than beautiful in analogy. Many of the falcon species sit on a tree for hours, watching for such little birds as come within reach of a sulden sweep*; it then pounces on its quarry, seizes it by its talons, bears it to its roost, and devours it piecemeal, These are prcciscly the manners of the true shrike; yet, with all this, the structure of the two birds, and their more intimate relations, are so different, that they camnot be classed in the same order: they illustrate, indeed, that system of symbolic relationship, termed analogy, which pervades creation; but the two

* Dr. Richardson, in Northern Zoology, vol. ii. p. 32, \&c. 
groups are in no wise connceted, and there is consequently 110 affinity between them.

(4.) The extcrual characters of the shrikes, in the more typical groups, are very decidedly marked. The bill, as in L. collurio ( fig. 114.), generally short and strong, is abruptly hooked at the end, and the notch so deep as to form a small tooth, more or less prominent, on eacli side : this projection is analogous to the teeth of quadrupeds, so far as to enable the lird to take a firm grasp of its food, and is used to divide it into pieces : the claws, also, as instruments of capture in the typical group, are peculiarly

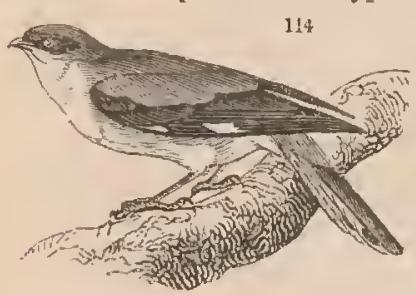

fine and sharp, - a character which pervades, more or less, the whole family. This mole of darting suddenly on their prey (rather than hunting or searching for it) is most prevalent in those groups which are nearest related to the flycatchers, whose general weakness, howerer, confines their depredations to the smaller insects; larger and more powerful tribes being the food of the typical shrikes.

(5.) The divisions of this family, and their scientific peculiaritics, have been dwelt upon at some length in another work (Northern Znol. vol. ii. p. 105.); we shall, thereforc, here give an abridged but more popular complexion to the subject, without detailing the reasons which have guided our views of thcir natural arrangement. The following are the five divisions or subfamilics:-1. The Tyrannina, or Tyrant shrikes; 2. The Ceblepyrina, or Caterpillar-eaters; 3. The Dicrurine, or Drongo shrikes; 4. The Thamnophiline, or Bushshrikes; and, 5. the Laniance, or true Shrikes. The first three of these sub-families constitute the aberrant circle, or that in which the characters of the shrike is least conspicnous. The fourth is the sub-typical ; and in the 
fifth we have the most perfect developement of the lanine structure.

(6.) We shall commence with the TrRannive, or tyrant shrikes, one of the aberrant divisions of the family, and thus gradually conduct the ornithologist to the more perfect or typical groups. It is seldom that the links of nature's chain, connecting two families, are so perfectly graduated as to perplex the scientific naturalist; but the connection between the family of shrikes, and that of the flycatchers (Muscicapide), by means of the group now before us, is so pcrfect, that it is difficult at present to determine where one tcrminates, and the other commences. The water-chats of Brazil pass by such impcrceptible degrees into the lesser tyrant shrikes of the same country (Tyrannula Sw.), that, although an observer on the spot, by studying the manners of these groups, might draw a line of distinction, the ornithologist of Europe, acquainted only with their dried skins, is at a loss to listinguish their remotc ramifications. $\quad \mathrm{Ve}$ may, however, form some idea on this difficult subject, by looking to the colours of the two groups. The waterchats (Fluvicolina'), which secm to conncet the tyrant shrikes to the flycatching family, or the Muscicapida, like very many other tribes, have their plumage llackand white variously blended, but without any mixture of green. The lesser tyrants (Tyrannula), on the contrary, are all of an olive-coloured plumage; that colour, in short, which is most adapted for concealinent among foliage, and therefore suited to their manner of life : between thesc, however, we find some curious birds, which borrow the habits of both groups. The species called by Latham white-headed tody, for instance, is black and white: its general resort is on the sides of marshes, where it perches upon the reels, and darts on passing insects in the same manner as a true tyrant shrike; this we have ourselves repeatedly witnessed. Azara says, that it likewise chases insects upon the ground *; so that wc have thus, in this one bird, the manners of both 
groups exemplified. Whether this, or the Tyrannula ambulans of Brazil, which lives on the ground likc a lark, constitute a gencric type in this division, is at present uncertain. The lesser tyrants (Tyrannule) are spread over the whole of $A$ merica, where they represent the true flycatcher (Muscicapa) of the Old World: both have nearly the same manners; and so closely do they resemble each other, that they can only be distinguished by their feet, tail, and wings. From these we may pass to the true or greater tyrants, by a little sub-generic group? (Milvulus Sw.) having very long forked tails. The habits of the typical tyrants intimately resemble those of the lesser, but they fecd upon largcr insects more suited to their own size; some imitate the kingfishers, by diving in the water, and they will even prey upon small reptiles. The species, which are numerous, swarm in tropical America, where they are every where seen, perched upon naked branches, and uttering, at short intervals, a sharp and monotonous cry. The tyrants are bold and quarrelsome birds, particularly during the season of incubation: the male will not then suffer any birds to come near its nest; and becomes so infuriated against such unconscious intruders, that it will attack both hawks and eagles, with a determination not to bc resisted, until they are fairly driven away.

(7.) Froin the tyrant shrikes to the Ceblepyrince or caterpillar-catchers, the passage is sufficiently marked by the Mexican genus Ptilinganys ${ }^{*}$, which brings them very close

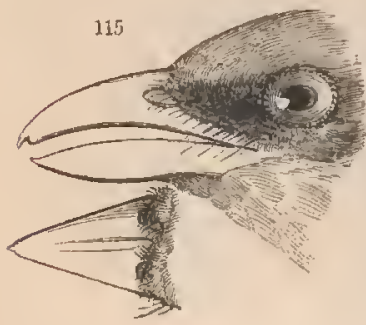
togrether. We now come to a group which is as strictly confined to the old world as the lastis to the New, yet not one species is found in Europe. Their bill (fig. 115.) is nearly as much depressed as that of the tyrants, but the absence of longbristlesround the baseshows tliat their food is quite different: we con-

*Zool. Ill. 2. pl. 62. 120. 
sequently find that these birds lived upon soft caterpillars, which they search for among the foliage of high trees. Le Vaillant first made us acquainted with this fact, and pointed out the group. Nearly all the specics are further distinguished by the peculiar construction of the feathers on the back: they are very thick sct, and, when the hand is passed over them in a direction towards the head, they feel as if intermixed with little sharp spones, concealed beneath the surface. This singular construction is seen also in the trogons, and, in a less degree, in the families of orioles and cuckows: but for what particular purpose it is "intended, we know not. The genus Phonicornis * unites this division to the tyrants: the other genera, whose habits arc unknown, will be found in the systematic arrangement.

(8.) We are Icd to the third division of shrikes, called, by Le Vaillant, Drongos (Dicrurince), by those caterpillar-catchers (Frucivora Sw.) which have only a few acute fenthcrs on their back; or the genus Oxynotus may possibly effect this junction. The Drongos are flycatching birds, having their bill both compressed and depressed, and the mouth furnished with very stiff long bristles. These are entirely unknown in $\Lambda$ merica, where they seem to be represented by the fork-tailed tyrants (Milvulus Sw.): like them they have the tail almost universally long and forked; and they associate, as do the American birds, in flocks, something like swallows, pursuing insects upon the wing in every direction. Bees appear to be a favourite food with these birls, as they are likewise witl the king tyrant of North America (Tyrannus intrepidus). Some are ornamented with little recurved crests in front of the head; othcrs have the neck feathers pointed and of a rich metallic hue; most have the tail remarkably developed; and nearly all are of a uniform glossy black colour: hence it becomes very difficult to distinguish the species, which, in truth, are much more numerous than has been generally imagined. In the genus Analeipus we first liave a few hright colours. Only

- Zool. Iil. od Series, pl. 52.

I 4 
three species, natives of Madagascar and the Indian islands, have yet been discovered; they lead us to the swift shrikes (Ocypterus Cuv.), so named from their very

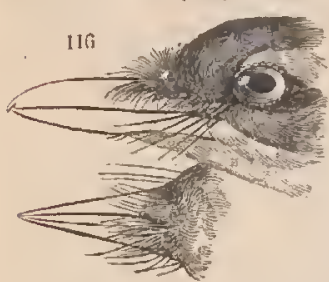
long wings: but in Tephrodornis (fig. 116.) these members again become like those of the Drongos. This latter genus is very remarkable; for, by the bristly nature and the incurved direction of the frontal feathers, we have a clear representation of Chatoblemma, and all those bristle-fronted birds which are analogical to Prionops and Dasycephala.

(9.) A few scientific remarks on the three last groups, forming the aberrant sub-families of the LANIAD\&, appear necessary. The approximation of the Dicrurinue to the Tyrannince las been thought so strong, and so decisive, that one ornithologist supposes they actually pass into each other. How this union, however, is absolutely effected, we are not prepared to state; yet it is not only highly probable, but what we should naturally expect; in which case the three aberrant groups would form their own circle. We might look for this union by means of the African Drongos (Edolius Cuv.) and the fork-tailed tyrants (Milvulus Sw.), since we have elsewherc pointed out (Northern Zool. vol.ii. p. 134.) the remarkable similarity of their manners and economy : yct, if we regard extcrnal structurc, it seems to us that the genera Tephrodornis and Saurophagus make even a still nearer approach. As yet very few species are known of these latter; and, therefore, any decisive opinion would be premature. Certain it is, that Saurophagus cvinces a much greater tendency to unite with Tephrodornis, than to pass, by a simple progression, into the true Laniadre by means of Faleunculus; while, on the other hand, Tephrodomis is nearly as much allied to Saurophagus as to Prionops, - that genus, in fact, which is the first on entering the Thamnophilince. 
(10.) We now come to the Thamnophimine, or bushshrikes, where we have the characteristics of the family much more distinctly developed than in either of the three precelling divisions. The habits of these birds are strikingly opposed to those of the abcrrant divisions. They live among thick trees, bushes, and underwood, where they are perpetually prowling about after insects and young and sickly birds; whilc in the breeding senson they arc great destroyers of eggs. They ncither seize their prey by the claws, nor do they dart at it by flight: and we thus find that the first are thick and rather blunt, and the wings so short as to indicate great feebleness of flight: the bill, being the instrument of capture, is always stout, much more lengthened than in the true shrikes, and very abruptly hooked at the end, which is armed with a strong tooth. These characters are variously modified in the five principal gencra which we shall now enumerate.

(11.) Of the genus Prionops only one species until lately was known (P.plumatus): it is common in Senegal, where it is stated to search for terrestrial insects in humid situations beneath the surface: this bird is remarkable for a peculiar kind of crest of rigid feathers, which not only falls back on the head, but is reversed ovcr the base of the bill, giving a complete protection to the nostrils and the sides of the mouth. Now, we have already seen this very singular strueture partially developed in the genus Tephrodornis; and there are so many other points of resemblance between the two, that we are inclined to look upon this as the point of union between the bush and the forked-tailed shrikes, or the Thamnophilince and the Dicrurina.

(12.) The genus Thamnophilus next succeeds: it is strictly typical, and shows the perfection of that particular structure which distinguishes the bush-shrikes : the bill (fig. 117.) is very powerful; and although many of the species far exceed the size of a thrusl, there are others not much bigger than a wrell. It is also a strictly geographic group, being confined to the hotter latitudes of $\Lambda$ meriea, 
where the species are very numerous: the plumage is thick, but the texture of the feathers uncommonly soft

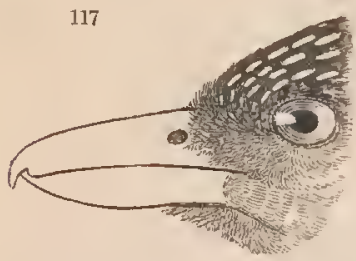

and lax: the colours are always sombre, but often variegated with much elegance by dark bands and white spots. One of the largest species, as if emblematic of their disposition, is covered all over with broad black stripes, upon a fawn-coloured ground, strikingly analogous to the marks of the tiger. The genus MIalaconotus represents these birds in Africa; and, although long confounded with them, their distinctions are very decisive: as the Ancrican group is distinguished by its dark colours, so is the African for the gaiety and brightness of the plumage. The Mulaconoti, in fact, are the most beautiful of all the shrikes : the brightest crimson, combined with glossy hlack, or clear green with orange or yellow, decorate most of the species; others, however, have the sombre colour of the American group, but thcy are never banded; while a few so nearly approach the ncxt, or typical slurikcs, that it is extremely difficult to distinguish them, otherwise than by the great inequality of their lateral tocs, - theinner one being always much shorter than the outer, and the latter often so connected to the middle toc that the feet become partiallysyndactyle. Of the Australian genus Collurisome nothing beyoud its external characters is known, while its species are very few, and their precise situation in this division remains to be remonstrated. They probably, however, represent the tenuirostral type.

(13.) The Laniance, or true shrikes, will complete the circle of this family. The precise passage between this and the last seems to be effected by a remarkable bird, disco verell in South Africa by Mr. Buschell; it forms our genus Chcetollemma, and is the only short-billed shrike which has the frontal fathers stiff, and directed forward upon the 
base of the bill: in this respect, and inits long wings, it presents a curious analogy to Prionops among the bush-shrikes. We need not dwell upon the peculiarities of the British shrikes ( $L . r u f u s, f i g .118$. ), since these may be learned

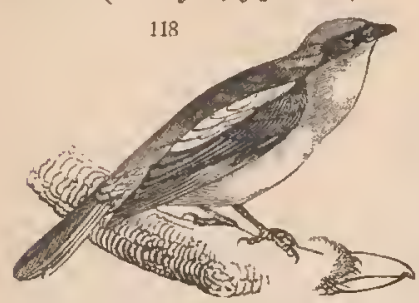
from any book on native Ornithology; and those found beyond our islands have precisely the same bold and cruel disposition. As the genus Lanius is preeminently typical, not only of its own family, but of the whole tribe of Dentirostres, or tooth-billed hirds, we accordingly find that Nature has furnished every country in the world with examples of this, her most perfect form: even in New Holland,-a region which so often appears exempt from those laws of creation which regulate the animal distribution of other

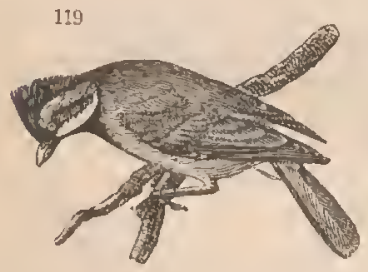
countries, - we have a peculiar type of the true shrikes, represented by the Falcunculus frontalis (fiy. 119.). Its manners, however, are singularly at variance with all others: instead of watching for its prey, and devouring birds or grasshoppers, by impaling them upon thorns and feeding on them at leisure, like the true shrikes, it climbs among the branches of trees, strips off the bark, and devours the hard-coated beetles which lurk beneath.* It would be difficult to conceive, theoretically, how a shrike could resemble a woodpecker; yet here is a bird having the form and structure of the first, with the habits of the second. This New Holland shrike, as being the scansorial type of the Laniana, becomes the 
representative of the titmice; and hence it has the crest and nearly the same colourcd plumage as the generality of species composing the genus Parus. This analogy, again, is further indicated by the grcat size of the hind toe; which is so umusually large, as at once to evince the clinbing habits of the bird, as affirmed by Lewin. This is not, however, the only analogy indicated by the colours of the bird; for if we look to the Bentivi tyrant (Saurophagus sulphuratus Sw.), we see a bird in all its most striking peculiarities of plumage coloured like that of the Falcunculus cristatus, with this difference only,that in one the back is olive brown, and in the other olive green. Now it is precisely at this point, where, according to our theory, the circle of the shrike family is closed; and thus these two genera will stand in juxtaposition. Certain, however, it is, that of all the tyrants, the Bentivi is that which most resembles a true shrike; not so much, perhaps, by its general structure, as by its living upon reptiles atud even carrion, and thus becoming, like the shrikes, both insectivorous and carnivorous.

(14.) The two other gencra comprised in this subfamily, are Telophonus and Nilaus; both of which, like those already noticed, are entirely excluded from the New World. Telophonus has such a strong resemblance to the typical genus Lanius, as well as to Malaconotus, that, without a knowledge of the true characters of these three groups, an ornithologist may be much perplexed in detecting their essential differences. The genus $L_{a-}$ nius, as already mentioned, is chiefly known in its outward appearance by its short and strongly toothed bill: but there is anothcr character, equally important, which all writers have hitherto overlooked: this is to be found in the equal length of the lateral toes, and the acuteness of the claws. Now, this structure of foot is also found, with a diminution harlly perceptible, in Telophonus; but then the bill is lengthened, so as to give these birds, at the first glance, an appearance of being Mulnennoti. This union of charactcrs is just what we should expect in such birds as were to represent the bush-shrikes in 
the circle of Laniance: for, although the bill is moderately lengthened in T. collaris (fig. 120. b.), and re-

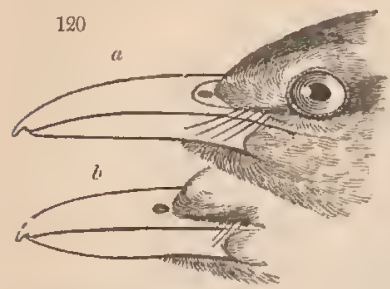
markably so in T'. longirostris* (fiy. 120,a.), still the culmen is regularly curved, and not abruptly hooked at the end, as in Malaconotus. We have no remaining doubt, in short, of the immediate union of Telom phonus with the pre-eminently typical genus Lanius; this union being effectedlby the Corvine shrike in one division, and the Teloph. loucogrammicus in the other. The second type is Nileus (fig. 121.), at present composed but of one

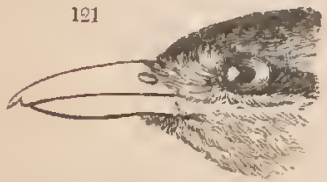
species : it has the bill much like that of a true shrike, but considerably attenuaterl; and the general organisation of the bird is weaker thau in any other gellus. This we think is the tenuirostral type of the circle, if so, it will consequently stand between Chrtoblemsma and Falcurculus. We have alrearly shown in what respect this latter genus may be vicwol as uniting the whole of the shrikes into one circular family; but as we have ventured so far as to trace out the smaller circle of Laniance, the ornithologist may well inquire in what manner Fulcunculus can be actually united to Lomius, seeing that its outward structure, no less than its scansorial habits, are so different. Now, this union is effected by a singular bird of Brazil, long bandied ahout (to translate an expressive French phrase) in systcms, from the tanager family to the old genus Lanius, and then again to Thamnophilus: its structure was so peculiar, that some years ago we placed it as the type of a supposed genus, under the name of Cyclaris: a more minute analysis, however, of this sub-family, and more especially the recent. 
discovery of Chatoblemma among the unexamined birds of our friend Mr. Burchell, has quite satisfied us that this is not one of the prominent types of the Laniane, but only an aberrant species of Falcunculus; we therefore cancel the name of Cyclaris, and propose for this bird the name of Fulcunculus Guicnensis. This is only one of the many instances wherein aberrant species have been mistaken for generic types, 'To these mistakes we are all liable, - for they can only be detected in a very advanced state of ornithological investigation, and we trust that the unscrupulous correction of our own errors, in this respect, will be a sufficient proof that, in cancelling very many of the supposed genera of others, we are actuated but by one motive,- that of the most perfect impartiality. It would be strange indeed, if any one, not possessed of divination, could determine the rank of a type before he has analysed the group of which it seems to form a part.

(15.) Having now sketched out the natural series in which the different divisions of shrikes appear to follow each other, let us pause to consider their analogies. On acutely survcying these groups, we find that nature stil] preserves, even under the form of the shrikes, a concealed resemblance to the primary orders of birds and the tribes of the perchers, as exhibited in the following table:-

\footnotetext{
Tribes of

$\left.\begin{array}{l}\text { Analogies. } \\ \text { Perchers. } \\ \text { Dextinostum. }\end{array} \begin{array}{c}\text { Bill short, toothed; seize their prey } \\ \text { by the foot. }\end{array}\right\}$

Sub-Familics of Shribies.

CoNmosraes.

\{ Bill lmgthened, compressed ; feet

LaNiaNiE.

SCaxsolrets.

Feet very short, hind toe lengthened. Dicruaris.

Texurrosters,

Bill weak, snowth smooth, feed only?

Fissirostres.

On soft substances.

CEBLEPrRINA.

Bill broad; fect upon the wing.

Trannexds.
}

Every one must have perceived the resemblance, both in form and habits, between the true shrikes and the falcons, and that Lanius, which is the first division or genus, is typical of the whole family. The skulking, thievish propensities of the bush-shrikes (Thamnophilina) and the jays (which belong to the Conirostres), in plundering 
the nests and destroying the young of other birds, is thus explained; since it is seen, by the above table, that these two groups mutually represent each other. The very great developement of the tail in nearly all the Drongo shrikes (Dicrurine), is also one of the most remarkable distinctions of gallinaceous birls, and of the scansorial tribe; which latter is eminently characterised by the peeuliar length of the hind toe, and by the tail feathers ending in fine points : all these charaeters are found also in the Drongos, but in no other shrikes. The soft and tender food of the eaterpillar-eatehers (Cehilepyrina) evinees, that even the T'nuirostres, - a tribe living chiefly upon juiees, - may be represented by inseetivorous shrikes; while the great depression of the bill, which has caused the tyrants (Tyrannina) to be confounded with the flyeatehers, their constant habit of capturing their prey upon the wing, and the reeorded fact * that more than one species dives in the water, all remind us of the fissirostral swallows, and the aquatic order of Nitatores.

(16.) Before dismissing our account of this family, we may here offer a few remarks upon the genera $V$ anga and Plutylophus, - two modern genera that appear to enter within its limits, but whose true situation we suspect is very different. The name of Fanga was given by Buffon to a singular and very rare bird of Madagascar, as big as a jay, but with a long abruptly hooked bill like a Thamnophilus. It has been usual to place this genus, as well as that of Platylophus, in the same group; but when we find that even M. Cuvier joins them with the large bush-shrikes, and several of the African $M a-$ laconoti, in his genus Vunga, we immediately perceive that a group so composed is entirely artifieial. The resemblanoe between Fanga destructor and the smaller speeies of Barrita, - whieh latter are obviously crows, - is so perfect, that a suspicion has always existed in our minds that both belonged to the corvine family. As we have seen, in the genus Falcunculus, a New Holland shrike assume.

$$
\text { * Northern Zoology, vol. ii. p. } 136 .
$$


all the manners of a woodpecker, may not Vanga, Barrita, \&c., by analogy of reasoning, be true crows, disguised under the economy, and much of the structure, of shrikes? Again, does the Vangce of New Holland and that of Marlagascar belong to the same genus? or even to the same natural group? The only specinen of this latter bird, known to exist in collections, is in the Paris Museum, but in too injured a state to allow of this question being answered. On the other hand, we happen to know, from unquestionable testimony that the Vanga destruetor of New Holland kills and eats small birds, in the same manner as the European species; and that it is actually called a butcherbird by the colonists. Yet this, after all, secms to us only a relation of analogy, just as in the case of $M$ niotilta, which, although it climbs like a Certhia, is merely a representation of those scansorial birds, and truly belongs, by affinity, to the circle of the warblers. Since our last observations upon Vangn were published *, we have been fortunate in procuring two or three species, which so connect the New Holland Vange with Barrita, that we no longer hesitate to place them all in the corvine family (Corvidre); where, also, we now arrange Platylophus, since it certainly has a greater rescmblance to Vanga destructor than to any of the soft-backed shrikes, or Malaconoti. This alteration does not, however, interfere with any thing we have said regarding Platylophus being a rasorial type: as such it remains, but merely fills that station in another circle. Plutylophus, in short, has all the outward aspect of a jay, combined with that of a shrike; while its remarkable crest. indicates to which of the primary types of nature we should refer it.

- Northern Zoology, vol. ii. p. 124. 


\section{CHAP. IV.}

THE DENTIROSTRAL ORDER CONTINUED, - THE MERULIDE, OR THRUSHES.

(17.) TnE family we are now to investigate is the most numerous, and consequently the most diversified, of the toothed-bill tribe. It is composed of birds inferior to the shrikes in that particular organisation adapted for rapacious habits; in other worls, the bill is much less toothed: and yet, in all other respects, they are certainly superior in the scale of creation. Their feet are not only stronger, but are as much adapted for perching as for valking, for constant use in moving among trees as for habitual exercise upon the ground. The blackbird of Europe ( fig. 122.), the fieldfare, and the whole of the typical thrushes (Meritina), are familiar examples of this perfection of structure, and will give the student a very good idea of the general size and appearance of the different genera in this division.

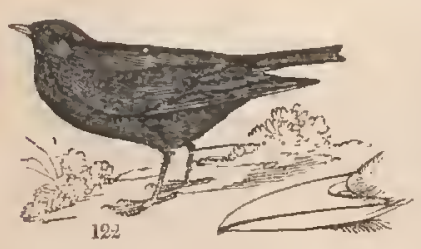

Like the corvine or crow farnily, - of which, in fact, they are but representtives, - these birds make their way upon the ground, in the air, and among trees, with equal facility; and this perfection of foot is more or less prevalent throughout the family. The form of the bill, also, shows a superior adaptation for general purposes: the notch near the

vOL. II. 
point is, of coursc, much slighter than that of the shrikes; yet it is sufficient to enable the thrushes to retain a firm loold of their food, while the superior length of this member cnalules the bird not only to capture fool that is exposed, but also such as lies bencath the surface of the ground. Thus we see the fieldfares and crows mutually assemble during autumn in large flocks, spread over new-ploughed fields, and traverse the ground in every direction in searcl of the same kind of food. The wholc of the shrikes are restricted to animal sustenance, but the thrushes devour fruits quite as much as they do insects. Above all, the sweetness, compass, and versatility of their song renders them the most perfect of all the Dentirostres, or toothbilled order.

(18.) The natural divisions of this family show in what manner the typical characters just intimated may be modified, according to the peculiar luabits of each, and the analogies they bear to other tribes. These divisions, or subfamilies, are as follows:-1. The shortlegged thrushes (Brachypodine, Sw.); 2. the orioles (Orioline, Sw.) ; 3. the long-legged tlirushes (Craterapodina, Sw.). These three form the abcrrant eirclc. 'The true tlirushes (Merulinc, Sw.) compose the typical group; and the ant-thrushes (Myotherince, Sw.) constitute the sub-typical. Our present limits will not allow of so full an exposition of these groups as the seientific ornithologist might probably desire; but he will find their peculiarities and relations, both of analogy and affinity, anply discussed in the ornithological volume of the Nurtliern Zoology. We shall, lowever, introduce in the following pages some additional remarks of a popular nature.

(19.) The short-legged thrushes (Brachypodina), as being that division which connects this family with the shrikes, naturally claims our first attention. This union appears effected by the genus Trichophorus, or bristle-neered thrusles which pass almost immediately into the Drongo shrikcs. 'These birds are peculiar to 
the hot latitudes of Western Africa and Oriental India; and have derived their name from three or four very

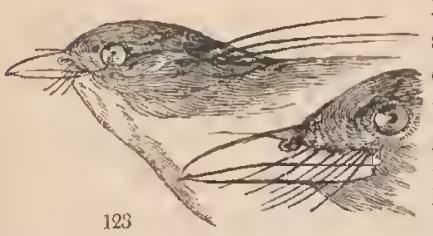

long bristles, which spring from the back of the neck or from the nape (fig. 123). Although these appendages are very well defined, and nearly three times the length of the surrounding feathers, they are yet so lelicate as frequently to liave escaped the scientific eye; hence many of the species have been overlooked. It is prohable that these curious birds, like the Drongos, capture insects upon the wing; for although their tail is not forked, yet the bristles round the bill are even longer and more rigid than those of the generality of fly-catchcrs. The two groups further resemble each other in the shortness of the feet and the length of the hind toe. The next genus has been named Phyllastrephus, from one of the species, according to Le Vaillant, loving to shelter and hunt among heaps of dead leaves. We know, as yet, but of two, and these are from the African continent: the long straight bill of these birds is continued to the genus Micropus, Sw., but wc now have a shortness of foot so remarkable that the tarsus is not even as long as the hind claw. Nature seems to have been very sparing of all these forms, since of Mieropus also we know at present but of four examples. On reaching the typical genus Brachypus, we have a perfect and a inost interesting assemblage of types, the five subgenera exhibiting a beautiful illustration of the five genera composing the entire circle. The pretty little Iöra secumularis of Dr. Horsfield, one of the most familiar birds of Java, connects Mieropus with Bruehypus, since it has the bill of the first and the toes of the last. The plumage is bright, and the feathers on the rump and back so long and soft, that 
when raised they resemble a round puff-ball. To these succeed the true genus Brachypus, which are also gaily coloured birds, thickly clothed with long soft feathers, and with a wide mouth. The bill is sliort, and bcing nearly sinooth, would seem to indicatc their food to be chiefly vegetable; but nothing is known of their economy. Nature, however, points out one of their analogies by clothing two species nearly in the plumagc of orioles. But still more beautiful than these are the green and blue birds, forming the next genus, Chloropsis, wlich seem inteuded to represent the splendid-coloured antthrushes (Pitta); botl groups, in fact, are confined to the tropical regions of India. These pitta-coloured birds lead us to the crested group of Brachypus, now named Hamutorris, whilc the fifth subgenus, Andropadus, completcs the series, by representing the bristlenecked thrushes. The whole of this group is confined to the tropical latitudes of the old world, nor is there any European bird wherewith to compare them. Our materials for understanding their cconomy are few and meagre. The information given by Dr. Horsfield respecting the Iöra scupularis seems to apply in a great measure to others of this genus noticed by Le Vaillant. "It is a bird," says the Doctor, "of social habits, and resorts to the vicinity of human lubitations; indeed, it appears to have rctired from the forests, and established itself in the trees and hedges which surround the villages and plantations. Its wings do not cnable it to fly very far, but it shows itself by short and frequent flights between the trees and branclies." " On referring to the collection of drawings formed by the late General Hardwicke, we find most of the species of Hamutorris are known in India by the name of Boulbul, where they are kept in cages, thus disproving the assertion so frequently marle, not only by poets, but naturalists, that this name is given in the East to the European nightingale: a facility in domesticating any bird or animal is an indirect proof that there exists a certain degree of

* Zoological Rescarches in Java. 
sociality to man, which other tribes do not possess. This very sociability, in fact, is one of the most remarkable peculiarities in this genus, and in the Importan (Andropadus fumiliaris, Sw.*) is carried to such an extreme, that Le Vaillant seems to have dreaded meeting this birk, from its kceping him company in a day's shooting, and diverting his attention from other birds; hence the narne he bestows upon it. The last genus of short-legged thrushes (Icteria, Vieil.) at present consists but of two birds: one, the Ieteria polyglotta, or yellow-breasted chat, of America; the other, a new species from India, which was once in the possession of Mr. Grey, of the British Muscum. Wilson has given a highly interesting account of the first, clearly showing its affinity to Arulropadus. It is equally attached to man, and would seern to surpass even the Boulbuls in the strength and versatility of its song. All these conterminous groups, moreover, lave a singular habit of turning over in the air during flight, something in the manner of a tumbler pigeon, and at other times of throwing themselves into strange and grotesque attitudes, just as their representatives in the circles of Fluvicoline and Saxicolina.

(20.) From the short-legged thrushes we pass to the orioles (Oriolina, Sw.) by such birds, in all probability, as the palm-thrush of Buffon, and the genus Dulas of M. Vieillot. The golden oriole of Europe (Oriolus galbula), an occasional visiter to these islands, is a well known and heautiful example of this group, distinguished by nearly all the species, being of a rich yellow or golden colour. They live in small flocks, fly well, and frequent high trees, among the foliage of which they seek for caterpillars, soft insects, and fruits. In the last group we took a final leave of the fly-catching birds, having the mouth provided with bristles, and we accordingly find in this that the rictus is smooth. The rump feathers of the orioles are formed something in the same manner as those of the caterpillar-catchers

- Le Vaillant, Oiseaux d'Afrique, iii, pl, 106, f. 2. 
among the shrikes, which they further resemble in the nature of their food ; in both groups the head is frequently black. Their analogy, in short, is direct and perfect. To this division belongs the magnificent Sericulus chrysocephnlus, Sw., or regent oriolc, of New South Wales, and the no less splendid Oriolus paradiseus, $T \mathrm{em}$. or golden bird of paradise, from New Guinea. Near to these we place the lovely Trena puella, Horsf. or fairy oriole, although it shows a considerable deviation in the colours, being blue and black instead of yellow. Of all these extra-European forms we know nothing but their skins; and even of the common European species a great deal is yet to be learned. The European oriole is said to build a long pursc-shaped pendulous nest, hanging from the high branches of trees, in the same way as those of the American hangnests. But although we lived several years in Italy, where thcse birds are common, we never were able to procure or to see its nest.

(21.) We are prepared for the Crateropodine, or long-legged thruslies, by the regent oriole, just mentioned, which differs from its congeners by the superior size and length of its legs. These birds, notwithstanding the confusion introduced among them by $\mathrm{M}$. T $\mathrm{cm}$ minck and others, are separated from all the Brachipodince both by economy and structure. Their general dimensious are much larger, and their feet are of a size and strength far excceding those of any other in the whole family. From the sloortness of their wings they fly with much difficulty, and then only for short distances, retreating among thickcts of reeds, and other aquatic plants, to which they cling. They show a singular partiality for places in the vicinity of water, and their notes are particularly loud and disagreeablc. The colour of the plumage in all the species is sombre; it is long, lax, and soft, particularly the tail feathers, which are generally broad and much rounded. As these birds perch so much among reeds, the strength thrown into their fect is not surprising; since, to retain a firm hold on such a slippery and awkward support 
the legs must be capable of taking a wide grasp, and the claws sufficiently sharp to retain a hold of the smooth stems. Now this is actually the structure secn in all the typical species. The bill is either long, as in Pomatorhinus, Horsf.; modcrate, as in Crateropus, Sw.; or short, as in Timalia, Horsf.; but in all cascs it is very much compresserl, entire, or very imperfectly notched, and of a peculiarly hard and horny appearance. The whole group is so little known, that wc know not yet which are the principal types. The large species obviously lead to the mocking bircls (for M. Temminck has actually mistaken one for the otlicr), while the lesscr so closely resemble warblers, that these also have been misplaced, by systematists, among the Sylviadre. Thic Timalia tharacica, of India (fig. 124.), erroneously re-

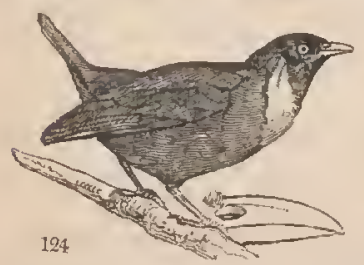
ferred by Temminck to the genus Pitta*, is merely the representative of the short-tailed ant-thrushes in this group.

(22.) On the union of the three foregoing divisions into one circular group we necd not dwell, since the fact has bcen unknowingly admitted by two ornithologists, and this in a very curious way. After long consideration between the puhlication of the name of the group and its characters, M. Tcmminck unites in his genus Ixos all those thrushes which have a bill shorter than usual; thus embracing the greatest part of our Bra= chypodince, and nearly the whole of the Crateropodina: in this he has been followed by Mr. Vigors, in the systematic list of birds annexerl to the Lifc of Sir Stamford Raffles; the characters by which these two groups are so remarkably distinguished - namely, their totally different conomy, and the opposite construction of their feet - liaving been either overlooked, and viewed as of little importance by these gentlemen. The truth, in

* Pitta thoracica, Pl. Col.

c) 4 
fact, appears to be, that the aberrant genera of the two groups approximate so closely that we might almost suspcct Icteria formed part of the Crateropodina, did we not believe that there is still another form to be discovered, which would unite the two subfamilies even more closely. The gcnus $I_{x o s}$, after all, may be continued in artificial systems, but cannot be adopted in natural classification; since it includes genera long before defined; and unites, under one name, birds which actually belong to diffcrent families.

(23.) Quitting the aberrant circlc, we enter among the true thrushes (Merulina, Sw.), exhibiting the typical perfection of the whole family. Our preceding remarks will tender it unnecessary to repeat the leading distinctions of these birds; and they are fully illustrated by our blackbird, throstle, and fieldfare : these, by their pointed wings and eventail, constitu te one of the principal divisions (Merula R.); another includes the mocking-birds (Orpheus); a third, the rock-thrushes (Petrocinolu); and a fourth is probably represented by the African genus Chatops. If the perfeetion of the thrusbes depended on the powers of their voice, the American mocking-bird would stand unrivaller : it is, indeed, the Orpheus of the feathered tribes; and has found an lustorian in Wilson, at once faithful and poetic. The true thrushes (Merula), like all other groups pre-eminently typical, are clispersed over all parts of the world; but the mocking-birds (Orpheus) are found only in America. Some of the species so nearly approach the long-legged thrushes (Crateropodina) that the junction of the two groups becomes unquestionable.

(24.) The rock-thrushes open a passage to the next division (Myotherina Sw.), comprehendinga large assem. blage of birds found only in the tropics, where they live chicfly upon ants. $\Lambda$ s thesc are to be searched for upon the ground, we accordingly find the legs very much developed, and mucl more adapted, in their general structure, for walking than for pcrching; the wings, as bcing littlc used, are feeble; and the tail sometimes so short 
as to appear almost cut off. As the natural arrangement of this division is much better understood than that of the last, we shall here enumerate the several types, or genera. 1. Myophonus. 2. Cinclus. 3. Dasycephula. 4. Myothera. 5. Pitta. The first may be denominated fowl-thrushes, since they are the largest in the whole family; and the neck feathers of the typical species, like those of gallinaccous lurds, are pointed, and very glossy. We know at present but of three or four species; but several others, departing somewhat from the type, appear to cxist : thcy have hitherto been found only in India. The next genus, Pitta, is one of remarkable beauty: they have the gradually curved bill of the true thruslies, but much stronger; the predominant colour of their plumage is green; the sides of the head and wings being generally variegated with

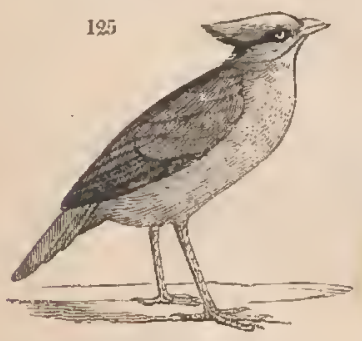
vivid blue: some species have a hood of black; and all are confined to New Holland and the neighbouring isles of the Indian seas. America, indeed, presents us with a representation of thcse in the subgenera Grallaria Vieil., and Chameza, Vig.; but the species are very few, and they are coloured in the homely hues of ordinary thrushes. To this group, as a subgenus, we refer Chlorisoma ( fig. 125.), called by some writers by the barbarous and unmeaning name of Kitta! 'The bill (fig. 126.),

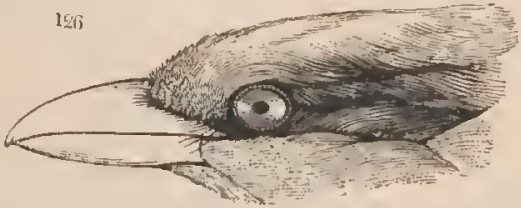

is clearly that of a thrush, while the legs place it among 
the Myotherine, of which it seems to be the rasorial subgenus, both on account of its size, its crest, and its affinity to Myophonus: there are two or three species, all natives of India. The genus Myothera, on the other hand, cliefly restricted to tropical $\Lambda$ merica, and comprises numerous species of a small size, clothed in dark colours, but prettily variegated with white: although distinctly scparated from the oriental group by their abruptly hooked and strongly toothed bill, they are yet so intimately allicd to the small busli-shrikes (Thamnophiline), that it is almost impossible to draw 2 distinction between them: to this point, howcver, we shall presently return. Of all the tribes of insects which swam in the tropics the ants are the most numerous; they are the universal devastators, and in the dry and ovcrgrown forests of the interior the traveller can scarcely proceed five paces without treading upon their nests. 'To kecp these myriads within due limits, a wise Providence has called into existence the antthrushes ( $f(y .127$.$) , and has given to them this parti-$ cular food. Both are proportionate in their geographic

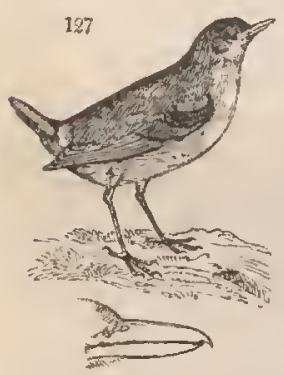
range; for beyond the tropical latitudes the ants suddenly decrease, and their enemies, the Myothere, totally disappear. As a general distinction by which this family may be known from the bush-slirikes, we may mention the difference in the feet - the structure of one being adapted for walking, while that of the other is more suited for pcrching. The antthruslies are very locally distributed ; for, although the group is tropical, we frequently found that a particular species, very common in onc forcst, was replaced in another by a second; while a third locality in the same district would present us with still another kind, different from those we had previously found. Cayenne and 
Surinam, in like manner, furnish us with many species totally unknown in the forests of Brazil.

(25.) The fourth genus of this division is one of peculiar intcrest; we have named it Dasycephala, from the forehead and crown being defended by very stiff bristly feathers. Unfortunately we are totally ignorant for what purpose this singular defence is given; but, if we may be allowed to conjecture, the habits of the bird probably may be terrestrial; and, as its bill is sufficicntly strong to penetrate beneath the surface of an ant's nest, the bristles, in sucl a case, would be an admirable defence for the nostrils, mouth, and eyes, against the attacks of the puny inhabitants. However this may be, Dasycephala is one of the most distinct types among the ant-thrushes, and is elearly connected to Myothera by the white-crested manakin of the old authors.

(26.) The water-ousels, placed in the genus Cinclus, constitute the fifth and last genus. Did we not know the peculiar habits of these semi-aquatic birds, ornithologists would have felt no hesitation in classing them with the Myotherce: in external appearance they are chiefly distinguisher from the American ant-thrushes by a more compressed bill, the notch being nearly evanescent, and the frontal feathers very much advanced. It was long believed that the only species in cxistence was that common to Europe and Britain: more reecntly M. Tcmminck has described a second, from Asia; and latterly we have ascertained two others, one inhabiting America*, the other, India. $t$

(27.) The five divisions, or genera, of the Myotherince having becn, as we conceive, now discovered, let us pausc a while to contemplate their analogies, and to see how far the principlc we have promulgated - that nature typifies all her higher groups in a single family, and even in a single genus - is borne out in this instance. In the first place, let us compare the various groups of the ant-thrushes (Myotherina), as here dis-

* Northern Zoology, vol. ii. p. 17S.

+ Id. ibid. p. 174. 
tributed, with the first and great divisions of birds into orders.

Orders of Birds.

Analogirs.

Genera of Mrothenine.

RAPTORES. $\quad\left\{\begin{array}{l}\text { Upper mandible ahrupty hooked and } \\ \text { furnished with a toath more or less } \\ \text { promiuent. }\end{array}\right\}$ Myothcra.

INsessones. $\quad\left\{\begin{array}{c}\text { Bill, in the typical groups, gradually } \\ \text { curved, the tooth obsolete. }\end{array}\right\}$ Pitta.

Rusoles. $\quad\left\{\begin{array}{l}\text { Bill more or less entire; wings short, } \\ \text { convex; feet very strong, and } \\ \text { formed for walking. }\end{array}\right.$

Gralestores, $\left\{\begin{array}{l}\text { Bill straight, or somewhat inclining } \\ \text { upwards; frontal foathers advanc } \\ \text { ing very far aver the base of the } \\ \text { bill. }\end{array}\right\}$ Cinclus.

Natatones. Feet partially syndactyle.

Dasycephala.

(28.) The two first analogies on this table, or those between the Raptores and IIyothera, and between the Insessores and Pitta, require no illustration, since the bills are modelled on the same plan in each. The Rasores, or the gallinaceous birds, are the largest in existcnce; as they live upon the ground, their feet are very strong; and their wings, not being much used, are short: now all these are characteristics of the genus Myophonus; both these analogous groups, in fact, have a strong, but an entire, bill; the most typical examples among the Rasores (as the pheasants, fowls, peacocks, \&c.) have the feathers on the neck of a pointed form, and richly glossed with metallic colours: Myophonus is the only genus of its family which puts on these peculiarities. The striking representation of the wading birds, given in Cinclus, is palpable to the most indifferent obscrver: it is, perhaps, one of the most beautiful analogies in creation; while that between the swimining order of Natatores and Dasycephala is shown in the partial union of the toes.

(29.) By comparing the ant-thrushes with the five tribes of perching birds (Instessores), we shall get explanations an scveral other parts of their structure.

Tribes of

Insessares.

Anclogies.

Genera.

Dentu rostres. Bill abruptly hooked. Myothera.

Cunirostres.

Fill more conic, the rotch small. Pitta.

Scansores. $\left\{\begin{array}{c}\text { Bill entire; shats of the tail feathers } \\ \text { ending in naked points. }\end{array}\right.$ Myophonus. 
Tribes of

Insessores,

Anciogies.

Genera.

Tenuirostres. $\left\{\begin{array}{c}\text { Bill slender; almost or perfectly en- } \\ \text { tire. }\end{array}\right.$ Cinclus.

Fissirostres. $\quad \begin{gathered}\text { Base of the bill considerably de- } \\ \text { pressed. }\end{gathered}$

We here havc an explanation why the tooth of the bill in Myothere is so like that of a falcon in miniature, since one group represents the other. The large conicbilled Pitte were thought by Linnæus and his followers so much to rescmble the corvinc family, that they now actually stand in their systems as "shorttailed crows." 'The analogy between the Scansores and Myophonus is particularly beautiful. No two tribes, to all appearance, can be more unlike each other than the gallinaceous and the climbing loirds; yet liere we have a genus unconnected witlı either, yet presenting three of their most prominent distinctions, viz.: the strong entire bill and robust walking feet of the rasores, united to the aculeatcd tail of the Scansores; this latter structure, moreover, is found in no other known bird belonging to the family of Myotherina. The watcrousels (Cinclus) and the Tenuirostres have the most slender, defenceless bills in their respective groups: that of the British species inclines upwards; so does that of Trochilus recurvirostres, and several of the waders. Jastly, Dasycepilulu represents the flat-billed swallow, or fissirostral tribe, by being the only gcnus in its family where the base of the bill is considerably depressed.

(30.) From the tribes of perchers we pass to the families of the Dentirostres, or tooth-billed birds, with which we will now compare the gencra of ant-thrushes. Families of the

Dentirostres.

Analogies.

Genera.

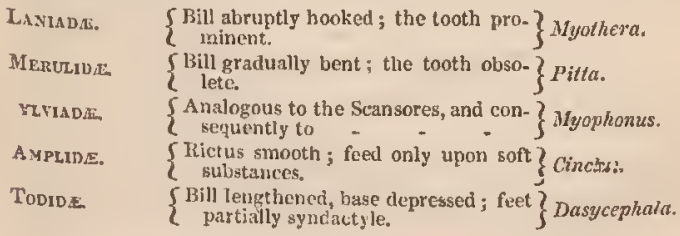


The first analogy (for so we shall at present term it) between the shrikcs (Laniade) and the American ant-thrushes (Myother $\boldsymbol{x}$ ) is so perfect, that MM. Cuvier, Temminck, Spix, Sc. have blended one with the other; while the true thrushes (Merulide) and the Oriental Pitte are still, in many systems, included in the same genus. The analogies letween the three next, or the aberrant groups, as is universally the case, are more remote; and it is only surprising that where groups are so very dissimilar there can be found any tangible and definite points of resemblance.

(31.) By comparing the genera of the Myotherine with the genera of the Thammophiline, or bush-shrikes, the accuracy of both will be severely tested.

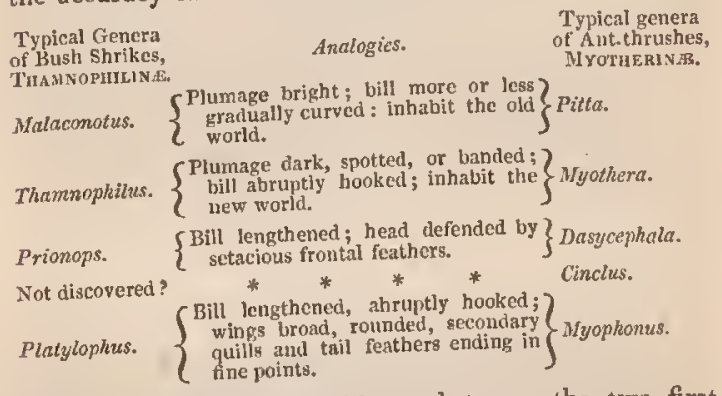

The remarkablc resemblance between the two first groups in cach column, in structure, colour, and country, is very striking; while that which makes Prionops a representation of Dasycephala is equally complete. Regarding the fourth, or tenuirostral, type of the bushshrikes, we do not fecl sure that it has been discovered; for although our suspicions point to the genus Colurisoma, still wc choose, for the present, to leave the question undetermined: finally, the analogy of Myophonus to Platylophus, as rasorial types at least, admits of no doubt.

(32.) The last test to which we shall bring our arrangement of the ant-thrushes, is by comparing it 
with the principal divisions or subfamilies of the shrikes (Laniada).

Subfamilies of the LAXIADR.

Zaniance.

Thamnophilines.

Dicrurina.

Ceblepyrina.

Tyrannina.

\section{Analogies.}

Bill short, curved from the base.
Genera of the MYothorinds.

Pitta.

Myothera.

Hind toe and claw lengthened; tail?

$\left\{\begin{array}{c}\text { Hind toe and claw lengthened; tail } \\ \text { ending in slender points; mouth } \\ \text { strongly bristled. }\end{array}\right.$

$\left\{\begin{array}{c}\text { Plumage particularly soft; mouth } \\ \text { smooth. }\end{array}\right.$ Cinclus.

?

$\left\{\begin{array}{c}\text { Base of the bill depressed, the tip } \\ \text { abruptly looked; mouth bristled. }\end{array}\right\}$ Dasycephala.

The value of this last table is twofold; for not only does it demonstrate the natural series of the Myotherina, but likewisc that of the Laniada, or shrike family. The speeulative theory, therefore, about the Thamnophiline being that aberrant group which conncets the shrikes with the thrushes - built, as it was, upon a mere supposition - must be given up. How, then, it may be asked, can we reeoneile this circular sueeession of affinities with the indisputable fact, that the Thannophilina blend so insensibly into the Myotherine that no omithologist can separate them? Our reply is, that in proportion to the smallness of any eireular group, so do its two typieal divisions show a eonstant tendeney to unite with the two eorresponding groups in the next circle; and that this tcndency in groups, where the species arc particularly numerous, is carried to such an extreme that a union is actually effected. Did our space allow of the digression, we could demonstrate this proposition still further in regard to the Sylviador, but we now eite this family as an absolute demonstration of what we have elsewhere stated as one of the properties of the same prineiple of natural system.

(33.) Before taking leave of the Merulida, their analogies deserve partieular consideration; sinee nothing is more caleulated to impress us with the harmonies of creation, than to eonteniplate the various modes by which nature unfolds her types and symbols. Tet 
us first look to the five principal divisions of the thrushes, and see in what manner they represent the primary orders of birds.

Orders of Birds.

INSESSORES.

Feet formed both

Subfamilies of Thrushes.

RAPTORES.

walking; omnivorou

Neruince.

\{ Bill with a prominent tooth; insec- tivorous Motherina.

Natatonas.

GitalLATORES.

RAsORE:

Feet remarkably short.

Brachypodina.

In this, as in all our preceding tables, each of the two columns form their own circle of affinity, the last group passing into the first, as in the instance of the Crateropodine, or long-legged thrushes, and the Meruline, or true thrushes. We thus have the following represcntations. The order of perching birds (Insessores), and the Merulince, are the most perfectly constructed in their respective groups, although the tooth of thcir bill is small and imperfect. This character, however, is very conspicuous in the rapacious order (Raptores), and in the division of ant-thrushes, both living entirely upon animal substances. The shortest footed birds are found in the swimming order (Natatores), and this also is the peculiar characteristic of the short-Icggetl thrushes (Brachypodince), and is that by which they are separated from all their congencrs. The orioles, living only upon very soft food, have the mouth particularly smooth, and thus typify the Grullutores, or wading order, whose food is precisely of this description. The analogy between the gullinuceous orker and longlegged thrushes (Crateropodince), is particularly beautiful: "the short convex wings; the broal spreading tail; great heaviness in flight; a sizc superior to all others in their respective circles, are the typical distinctions of both: even the nostrils are formed on the same principle; the membrane by which the aperture is deiended, and which, in other birds, is soft and pliable, 
in these assumes the appearance of a hard scale, as if covered by a prolongation of the horny substance of the beak. The loud, harsh, and disagreeable notes of both groups, is another singular point of resemblance which almost completes the picture." *

(34.) By comparing this family with the tribes of the perchers (Inseswores), we shall gain an explanation of several other peculiarities which are not developed by the last table.

Tribes of

Perchers.

Analogies.

Subfamilies of 'Thrushes.

Conirostres. $\quad\left\{\begin{array}{c}\text { Wings lengthened; bill gradually } \\ \text { arched, the tip slightly notched. }\end{array}\right\}$ Merulina.

DentiRostres. $\left\{\begin{array}{c}\text { Wings rounded; bill toothed, and } \\ \text { abruptly hooked. }\end{array}\right.$ Nyotherine.

Fissinostres. $\quad \begin{gathered}\text { Feet very short; mouth bristled; } \\ \text { insectivorous. }\end{gathered}$ Brachypodince.

Texurostetes. $\left\{\begin{array}{c}\text { Feet short; mouth smooth; nectar- } \\ \text { ivorous or frugivorous. }\end{array}\right.$ orioline.

Scansores. $\quad\left\{\begin{array}{c}\text { Claws acute, formed for clinging to } \\ \text { vegetables. }\end{array}\right.$ Crateropodinc.

(35.) By this table, the analogy of the orioles, scarcely perccived when viewed in direct reference to the Grallatores, are brought much more forward. These birds, with the whole of the Tenuirostres, or honeysucking tribc, are remarkable for the soft and delicate nature of their food; and both, in uuison witl such habits, are destitute of bristles to defond the sides of their mouth from injury. The humming-birds sip the nectar of flowers, while the orioles feed upon the fruits. The ornithologist may have remarked that some peculiar habits of the long-legged thrushes (Crateropodina), could not be explained in the last table, by their direct antlogy to the gallinaceous order (Rasores), the latter living in plains, and seldom perching, whereas the former are scarcely ever seen upon the ground; but this is at once illustrated by their relation to the climbing-birds ( $S c n n$. sores), both groups being, in different degrees, scansorial, and living almost entirely among the upright stems of vegetables.

VOL. II.

* Northern Zoulogy, vol, ii. p. 163. 
(36.) By comparing the family of the thrushes with that of the shrikes, we shall see with what beautiful regularity nature has proceeded in typifying one in the other; each eontains five divisions, or subfamilies, mutually represented in the following manner :-

Subfamilies of

IANIADE.

Laniante.

Thamnophiline.

Dicrurine.

Ceblepyrina.

Tyrannina.
Analogies.

Bill graclually arched.

Bill straight, abruptly hooked.

Feet short; hind toc lengthened.
Subfamilies of Nerulide

Merulince.

Myotherine.

Brachypodince.

$\left\{\begin{array}{l}\text { Mouth smontl ; rump feathers thick, } \\ \text { subspinous, or rigid. }\end{array}\right.$

$\left\{\begin{array}{c}\text { Tail very broad; raouth bristled; } \\ \text { live in the vicinity of water. }\end{array}\right\}$

The first analogy of this table, or that between the true shrikes (Laniana) and the typieal thrushes (Merulina), at first sight appears not only remote, but even questionable: it is, ncvertheless, one of the most extraordinary and most beautiful tliroughout creation. Let us take a typical example of eaeh group, and compare their form, colour, habits, and economy, as dcscribed by authors who have given us their unbiassed testimony, totally ignorant of the use we should make of it. One of these birds is the Lanius Carolinensis of Wilson, the other the American mock-bird (Orpheus Polyglottus Sw.). The words in Italics alone denote their respeetive differenees.

LaNivg Carounexsis Wilson.

Loggerheaded Shrike.

Dill arched from the base, short; mouth bearded.

Colour above krey, beneath white; earsbiact: wings obliquely rounded. earsblack ; wings obliquely rounded, wings obliquely rounded; wings and
black, the quatls with a white band tail of the same structure and colour tipt with white.

4s Mrakes it: nest in 2 detached bush in the manner of the morkinghirds." - Wilson, American Ornithology, vol, iii. 1. 57 .

lieeds of crickets and grasshop. pers. - Whilsm, p. 57 ,

I'he cincreoù and red-backea shrikes imitate the notes of other vol. ii. p. 12.

American Mocking-bird.

Bill arched from the basc, longer; mouth bearded.

Colour above grey, beneath white : wings obliquely rounded; wings and tail of the same structure and colour as those of Lanius Carolinensis.

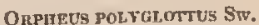


Lanitis CaroLivensis, Wilson.

Loggerheaded Shrike.

Shrikes and rapacious birds always disgorge the undigested parts of their food in round pellets.

"In Georgia, aecording to $\mathrm{Mr}$. Abbot, the Carolina shrike is known by the narne of bigheaded moekingbird." - Latham, General History, vol, ii. p. 7.
ORPnEUS POLYGLOTTUS, Sw. Ameriean Mocking-bird.

Mr. Bartrum writes, "I have observed that the mocking-bird ejects from his stomach, through his mouth, the hard kernels of berries, \&c., retaining the pulpy part. Wilson, vol. ii. p. 25.

(37.) It seems impossible to conceive in what way this most extraordinary resemblance can be rendered more complete. Hcre are two birds, - typical examples of two distinct groups, - birds of the same size, - clothed in nearly the same colourcd plumage, - seek. ing the same kind of food, - agreeing in the structure of their wings and tail (almost in their feet), - building the same kind of nest, and in similar situations, imitating the notes of other birds, - ejecting their unserviceable food in the same manner, - and, finally, callcd almost by the same name, - and yet totally distinct in real affinity. Well may we exclain, "Wonderful are THY works, O Lord! for they are full of wisdom." If such astonishing relations become apparent on gaining an imperfect glimpse of Hrs system, how inconceivably sublime must be the whole! A glance at the bills of these two birds is sufficient to sliow their real distinctions; yet, were this organ concealed, few, even among naturalists, would letect their difference.

(38.) But to proceed to the other comparisons. The analogy between the bush-shrikes (Thamnophilince) and the ant-thrushes (Myotherince), as we have already seen, blends into an absolute affinity; while the two families are also united by the drongo shrikes (Dicruriance), passing into the short-legged thrushes (Br/tchypodince), in the manner we lave before explained. The resemblance between the orioles (Oriolina) and the caterpillar-catching shrikes (Ceblepyrince) is to the full as strong. Both have long but obliquely rounded wings - short feet and tails - a bill broarl at the base 
and compressed on the sides - and the mouth destitute of stiff bristles; but, what is more singular, the rump feathers in both are of precisely the same construction. It will be remembered that thesc, in the catcripillarcatchers, arc particularly thick set, aud that, when pressed against by the hand, a sensation is given of being pricked, just as if the shafts of the feathers bcneath the surface terminated in little sharp points. 'This supposition, although it has been urged as a fact by Cuvier, is entirely erromeous. 'Thesc f'cathers have the shafts very thick at the base, but towards the middle they suddenly become very slender: by bcing pressed against they bend into a sharp angle, the thicker part of the shafts resisting, and the thinner yiclding to the pressurc; the angle thus formed, is, in fact, the prickle which all ornithologists have bclieved in. Now, although the rump fcathers of the orioles do not possess this property in the same degree, the shaft is formed on the same principle: it is thick at the base, but suddenly becomes very fine; and if gently pressed, the hand fcels a prickly resistance: the same character belongs to the beautiful Irena Puella, a bird classcd by the Linnaean naturalists with the rollers, and by some of the moderns with the drongo shrikes. Dr. Horsfield, therefore, is perfectly correct in assimilating it to this group. 'The last analogy is that between the tyrant shrikes ('Iyrannince) and the long-legged thrushes (Crateropodina), which are thus brought into contact. As these two groups are the most remote, and both pass into different families, so their resemblance is morc distant. Yet there are not wanting certain characters which they possess in common: the breadth of the tail is peculiarly conspicuous in both; the bristles round the mouth of the long-legged thrushes are more developed than in any other group of the family; another character which is common to the tyrants. It has been mentioned by Wilson, and we can coufirm the fact from personal expcrience, that most of the tyrant fly-catchers coustantly resort to the vicinity of water, into which they frequently dive. Now, this fact explains at once the 
aquatic habits of the long-legged thrushes, a point which could not be elucidated by any of the tables we have already given. These two groups, in short, are the only ones, in their respective families, which habitually frequent such situations.

(39.) The last set of comparisons we shall bring forward is between the family of thrushes (Merulida), and the order of Tenuirostres, or honey-suckers, groups so very remotc, and so distinct from each other, that we may almost feel surprise that any reseinblances can be traced between them. Yet it bccomes important to ascertain this, since several authors, on the belief that the subgenus Chloropsis has a brush-like tongue, have consequently considered it is a mcliphagous group. The Paradise oriole likewise lias becn thonght to form one of the true Paradise birds by so many, that we may suspect therc is some foundation for these relations in nature; a glance at the following table will accordingly prove this to be the fact.

Subfamilies of

Thrushes.

Meruline.

Myotherine.

\section{Brachypodine.}

Orioline.

Crateropodine.
Families of Tenuirostres.

\section{Analogies.}

(The most typical of their respective) pointed, in the other leeble and Cursurids rounded.

(40.) The resemblance betwecn the two first groups in each column cannot be supposed very strong, if we look to form or structure, since scarcely any two birds can be more unlike than a thrush and a liumming-bird. They agree, however, in fucding both upon vegetable and animal food, and further correspond in being the most typical of their several groups. Who that compares the beautifully-coloured Pitte of India, particularly the Pitta cyanura Vicil., with the Cinnyris Sene- 
galensis, - both elothed in the richest colours, and both cressed by brilliant violet lines on the throat, breast, and body, - but will be struck with the analogy? But these are faint when comparcd with those between the Braehypodine and the Meliphagida. It is here we get the true value of this table, since it shows the supposed affinity of Chloropis to the honey-suckers (Meliphagida), is merely a relation of analogy. The Paradise oriole, in like inanner, typifies, in its own family, the true $\mathrm{Pa}$ radise birds; while the peculiar hardness and compression of the bill in the two last groups, their long, soft, and graduaterl tails, and partiality for the vicinity of water, render thcir analogy almost unquestionable. It is, indeed, still a matter of doubt, whether the Promerops Capensis belongs to one or the other. These relations, however, from being less direct than several we have previously noticel, might be termed fanciful, lad not naturalists, by mistaking them for true affinities, stamped them with an additional value, while each group is placed exactly in that station it holds in its own circle of affinity.

\section{CHAP. V.}

2HE DENTIROSTRAL ORDER CONTINUED, - ON THE SYLVIADA, OR. WARBLERS.

(41.) The chief peculiarity which runs through this numerous family, is the very small size and delicate structure of its individuals: Excepting the lummingbirds, we find among these elegant little ercatures the smallest birds in creation. The diminutive golden-crests, the nightingale, the white throat, and the wood wren, are all well known cxamples of genuine warblers, familiar to the British naturalist. The groups of this extensive family, spread over all the habitable regious of the 
globe, are destined to perform an important part in the economy of nature: to them appears intrusted the subjugation of those innumerable minute insects which lurk within the buds, the foliage, or the flowers of plants; and thus protected, escape that destruction from swallows, to which they are only exposed during flight. The diminutive size of such insects renders them unfit for the nourishment of the thrushes and the larger insectivorous birds, while their number and variety only become apparent when the boughs are shaken, and their retreat disturbed. How enormous, then, would be their multiplication, had not nature proviled other races of beings to check their increase! No birds appear more perfectly adlapted for this purpose than are the warblers. They appear among us, for the most part, on the first appearance of spring, when the insect world is called into life and activity, by the renewal of vegetation; and they depart towards autumn, when these minute depredators diminish, and when the services of their enemies are consequently no longer required. As different localities are assigned to different tribes of inscets, so do we find a similar diversity of haunts among the various groups of warblers. The gold crests and wood warblers (Sylviance) confine themselves principally to the higher trees, where they search for winged insects among the foliage; or capture them, like flycatchers, when attempting to cscape. The reed warblers and the nightingales (Philomelince) haunt the vicinity of waters, or the more dense foliage of halges, for insects peculiar to such situations. The stonechats (Saxicolina), on the contrary, prefer dry commons and wide extended plains, and feed on insects appropriated to these localities: while those which belong to humid and wet places are the particular food of the wagtails and titlarks (Motucillince): lastly, the Pariana, or titmice, search with the greatest assiduity among the buts and tender shoots of trees, and thus destroy a host of hidden enemies, inimical to vegetation. The natural distribution of this family is thus marked by peculiarities of habit, 
no less than by a variation of structure adapted to such habits.

(42.) I3ut before we proceed further, let us exhibit the divisions just intimated in a more definite manner, in the following table of the subfamilies:-

Circles.

Sruvins, or Warblers.

Subfamilies.

1. Typical. $\left\{\begin{array}{c}\text { Bill very slender, compressed; lateral } \\ \text { toes equal. }\end{array}\right\}$ Sruviande.

2. Sub-typical. Bill and general structure more robust. PHromerivis

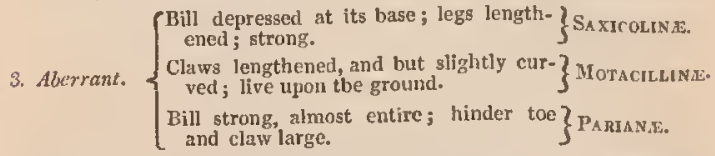

As we shall subsequently touch upon the analogies resulting from this arrangement, we may at once proceed to notice the several divisions in more detail.

(43.) The Motacilline, or wagtails, form the most aberrant division of this group; they are particularly interesting from their various and almost complicated relations. They are a small group of purely insectivorous birds, very well exemplified by the few species so common in this and most other countries of Europe. They live almost entirely upon the ground, where alone they seek their fool, which consists entirely of insects : damp meadows, and the sides of standing or running watcrs, are the favourite haunts of these birls, and they run with such celcrity, that, in this respect, as well as in thcir general black and white plumage, they can only be compared to the plovers. We consider them, in fact, as collectively representing the tenuirostral type of the percliers, or, what is the same, the grallatorial type among birds. The rlifferent wagtails of England are of the inost typical gencra (Motacillu and Budytes). These are succeeded by a beautiful little group peculiar to India, named Enicurus (fig. 128.), nearly all of which have a remarkably forked tail, and are clothed in a plumage of pure white, variegated with deep black: next to these comes the genus Anthus, or titlarks, slender- 


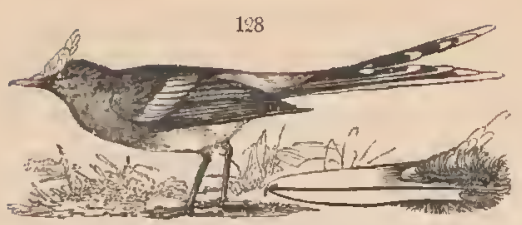

shaped birds, having the plumage and long hinder toes of the true larks, but with the slender bills of a wagtail. This union of characters all ornithologists concur in viewing as a plain intimation of the mode in which the dentirostral tribe is united to that of the conirostral. Anthus, in fact, seems to be placed at the very extremity of the Dentirostres, just as the family of the Alaudina, or true larks, is in the circle of the Conirostres; in other words, they are not only analogous, but this analogy actually blends into an affinity. In addition to the four principal types or genera of the Motacillinn, above enumerated, we have been fortunate in detecting what we consider to be the fifth or fissirostral type, loug after we had expressed our firm conviction that type had not yet been retected. Ilitherto none of the wagtails had been detected in America; but the recent researches in Chili have brought to light a most singular birl, long ago figured by Buffon, but which had been lost to our modern collections, until very lately. This is our Lessonia erythronotus, which at present stands as a solitary example of the fisserostral type of the Motacillina. This singular bird has the feet and long hind claw of Anthats and of Motacilla, between which we assign it a station. It is well known that the greater part of the Motucilline are perpetually moving their tails, and we shall now show how this character is continued to the uext division.

(44.) We enter among the Parmans, or tits, by the American genus Soiurus, which, as its name implies, is remarkable for the motion of its tail ; one species (Seinrus aquatirus* Sw.) frequents the siles of streams,

* Northern Zoology vol. ii. pl. 4. . 
and runs upon the ground; while another (S. aurocapillus Sw.) is confincd to damp woods, and runs along the low branches of trees." Here we have a change of economy, which plainly shows that nature nas assumed a new form; and, as the habit of running along branches of trees is the chief faculty of the scansorial birds, or of their representatives, so we may suppose the group next in succession to the Motacilline would possess something of the same characters. Now these are displaycd in the genus Accentor. We recollect hearing read, at the Linnean Society, a very interesting notice on the manners of a specimen of this rare British bird, which was killed near one of the public buildings at Oxford; and every ornithologist must regret that this paper is not to be found in the society's transactions, since it brought to light one of thosc important and long concealed facts, which frequently decide the true station in nature of an entire group. The bird in question was seell to climb so adroitly round the steep abutments of the buildings, as to baffie for a considerable time the aim of the person who eventually shot it. We can also state, from our own personal observation, that the common hedge sparrow frequently hops along the whole length of a strong oblique branch, pecking into the crevices of the bark, so that the observer is instantly reminded of a scansorial creeper, or of a woodpecker.

(45.) The Pariane, or titmice, may therefore be said commence with the genus Accentor, which stands at the confines of that group which contains the most scansorial warblers in this family. This group or subfamily is represented by the following genera: Accentor, Parus, Sylvicola, Setophagn, and Trichas. So many well-known examples of the titmice enrich our native fauna, that it would be superfluous to describe their habits; known, as they must be, to every obscrver. The short, stout, and nearly conic bills of these active little climbers, are admirably adapted for pecking into

\footnotetext{
* Northern Zoology, vol. ii, pl, 227.
} 
the bark of buds, and thus extracting the small insects that there lie concealed. Of the five types of form, or subgenera, proper to the genus Parus, that which we have formerly named Parisoma, is the connecting link to Accentor. It is one of those small birds of South Africa, figured, indeed, by Le Vaillant, but of which the greater part are known only by his plates: the four others are composed of the ordinary or typical titmice (Parus), the hangnest titmice (Egithalus Vig.), the Brazilian titmice (Hylophilus Tem.) and that excessively rare little bird forming Vieillot's genus Egithina. Parus and Egithalus are distinguished by their conic, sharp-pointed, and entire bills; while the three aberrant types have this member notched; but in all five the feet (so constantly employed in the great exertion of climbing) are particularly strong and inuscular; the hind toe, also - upon which all climbing birds depend so much for assistance - is large and powerful.

(46.) The discovery of the five subgenera of Parus, independent of the verification they afford by their perfect analogy to the correctness of the corresponding types of the genus Sylvicola subsequently dctailed, is of much importance, since this discovery enables us to prove, beyond all reasonable doubt, that neither the longtailed nor the bearded tits (Parus caudatus and biarmicus) are types either of gcnera or subgenera. We have already alluded to the station in which, after the most minute analysis, we have placed the Parus biarmicus ", which is only an aberrant species of the restricted subgenus Parus, as the latter now stands : from this bird always living in the vicinity of water, it becomes that species

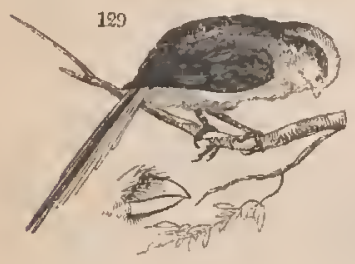
which represents the natatorial type; whilc, in the greatly developed tail of Prarus caudatus ( fig. 129.), it is easy to perceive another aberrant species, typifying the $R a$ sores. We have repeatedly remarked that groups, pre-

* Classification of Animals, pw.270, 271. 
eminently typical in their own circle, almost invariably present us with these variations in the form of their aberrant species. The restricted genus Parus is precisely of this description: it is the precminent type of an entire subfamily; and hence, like Corvres, Lanius, Sylvia, and a great number of other genera, holding the same rank in their own circles, it contains a greater variety of modifications, in the form of its species, than genera which are not preeminently typical. The whole of the subgenera of Parts are distinguished from those of Sylvicolu, by cliaracters the most simple and beautiful. They all have that peculiar strength of foot so con-

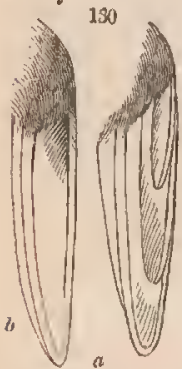
spicuous in our native examples, and their wings are invariably rounded; that is to say, the first quill is short, and the second and third so graduated, that the fourth becomes the longest ( $f i g .130, a$ ). The bill also is short and thick, generally more or less conic, and sometimes (as in the types) very strong: the upper mandible may be said to be entire, for in the only genus (Parisoma) which has the culmen arched, the notch is so small, that it may be termed obsolete. Wc are thus enabled to distinguish the whole from the neighbouring group we shall now enter upoul.

(47.) The second division of the titmice forms our genus Sylvicola. This exteusive group possesses peculiar interest, inasuuch as it exlibits, after the most minute analysis, a demonstration of those general laws of classification, which we consider the foundation of the natural system, and by which, as we conceive, the whole creation has been regulated. Without, however, anticipating conclusions before we have detailed facts, it will be necessary to premise, that the whole of the birls whose natural arrangement we shall now cousider, with the exception of one group, are natives of North America; and that alınost every fact we shall have occasion to mention, as illustrating their habits and economy, will be found recorded in the 
pages of Wilson, one of the most watchful and most accurate observers of nature that has ever existed in any age or in any country.

(48.) The subgenera of this extensive gcnus are not only all knowu, but contain many striking examples, arranged under tle following divisions:-1. Vermivara Sw., the worm-eaters; - 2. Sylvicola Sw., the titmice-warblers; - 3. Dumecola $\mathbf{S w}$, the bush-warblers;-4. Zosterops Vig., the white-eyed warblers ; 5. Mniotilta Vicil., the creeping warblers. The peculiarities of each, and their conuection among themselves, will be now explaincd. Vicwing these lesser groups collectively, we discover a strong peculiarity in the form of the wing (fig.130. b.), which at once separates them from all the neighbouring groups. The first quill feather is invariably long, and is generally equal, or but very little inferior to the seeond and third. Whereas, in the five subgenera of the titmice (I'arus), as already observed, the wings arc as invariably rounded, and the first quill is not more than half the length of the third ( $f g .130$. a): this is the easiest, as it is the bost, mark of discrimination between the two groups.

(49.) The subgenus Vermivara, or worm-eaters, includes a few species peculiar to North America; by their pointed and entire bills, they give us a representation of the conic-billed titmice (Egithalus Vig.), and they represent, at the same time, the order Coninostres in their own vircle. The difference between this group and Egithalus is sufficiently marked by the structure of the wings, for their bills are prccisely alike. The worm-eating warblers, dcpend for locomotion more upon their wings than on their feet; hence we find, that the former are more adapted for flight, and that the latter are more slender and fceble than those of Egithulus. The peculiar manners of this group was first made known by Wilson; and although we defined it from its external characters many years ago, subsequent writers have still continued to confound the worm-eaters with the honey-sucking Necturina of the 
Tenuirostral race forming the genus Dacnis of $\mathbf{M}$. Cuvicr, but previously named Nectarina by Illiger. The subgenus Sylvicola is the second or typical division of the whole group. These are the true titwarblers of $\Lambda$ merica, so closely resembling the wormeaters, that many writers have placed both in the same genus; they may, lowever, readily be detected by a slightly arched bill, notched near the end of the upper mandible. The slender structure of their feet, the pointed form of their wings, and the scattered, weak bristles of the mouth, suggest the idea that the mode of catching their prey must not be unlike that adopted by the true flycatchers, and such, accordingly, turns out to be the fact; they are, in short, lively, active, gaily coloured little birds, continually hunting after sedentary insects, and pursuing such as fly from bough to bougl ; their habits thus forming a singular union of those of the wool-warbler, the tits, and the flycatchers: so close, incleed, is this analogy, that Meyer has confounded them with the first, Linnaus and Buffon with the second, and even Wilson considers some as belonging to the third of these families. Nor was the great American ornithologist very far from the truth, since they actually pass into a subgenus, which certainly would stand in the old Limnean group of Muscicapa.

(50.) In Dumecola, the third subgenus, we consequently find the bill no longer slender and compressed, as in Sylvicola, but decidedly more flattened; while the slender scattercd hairs at the lase become more rigid, lengtlicned, and directed forward in the manner of the true flycatchers. This subgenus is peculiar to tropical America; it is composed of those very small birds whicl seem to be half warblers and half flycatchers, having the feet more lengthened, the wings more pointed, the bill narrower and less depressel, and the sides more rouuded, than the small tyrants (Tyrannulu), already noticed. The Dumecola ruficauda, formerly cited as an exanple, is not, perhaps, a typical one, but rather the $M u s-$ cocapa Diops of Temminck, which we have hitherto been 
unable to examine. There are, however, several undescribed birds from Brazil now before us, which appear to belong to this group, all of which have the second quill very little longer than the first. This character of the wings seems to be the best we can at prcsent depend upon. We have no doubt that when the small warblers and flycatchers of tropical America have been properly studied, this division will be augmented by many species, and the true type of the present subgenus clearly ascertained. Certain it is, that among the little birds now before us, there is, in three or fourspecies, strong indication of that white circular ring round the eye, which is the leading distinction of Zosterops, the very next genus which, according to our views, succeeds Dumecola in the circle we are now investigating. We ean never hope to ascertain the natural station of any being, or group of beings, in the great system of nature, so long as other groups, to which it seems to havc a strong resemblance, remain uninvestigated. Now this is the case with $D u-$ mecola: many species seem to be as clearly, if not more, related to the grenuine tyrants (Tyranninx) than to the Sylvicola; and yet there are otbers which scem $a b-$ solutely to ammul the first of these relations. Hence it follows, that, before the true characters of these groups are known, the Tyrannince must be analysed with the same degrce of care as that which we have bestowed upon the Sylvicolce. Until this is done, it may still remain a question whether Setophaga does not actually fill the station we have here assigned to Dumecola; so that these two groups, in fact would become transposed.

(51.) The subgenus Zosterops is the fourth type, and contains the white-cyed warblers. These little birds are chiefly confined to the Eastern hemisphere; but we have the drawing of one species not yet described, which is asserted to inlabit Cayenne. In this group, formed but of eight or ten species, we have the dcpressed bill of Dumecolu joined to the more pointed shape of Sylvicola: and although the wings are of the same pointed form as in the last-named group, the whole 
external structure of these birds separate them from all others : the legs are stout, and the hind claw sufficiently

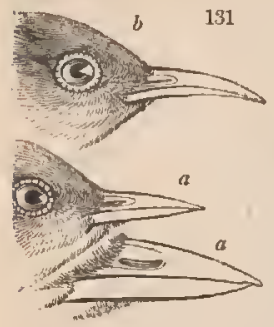
lengthened to betray an indication of scansorial habits. In this member, and in the shape of the nostrils ( $f i g .131 . a$ magnified), we trace a marked analogy to the honeysuckers (Diceum Cuv.): this analogy is so strong, that it has been mistaken for an affinity, since we have a true Zosterops under the complete disguise of a suctorial creeper in the Certhia borbonica of authors (b).

(52.) Mnotilta, the fifth and last subgenus, remains to be illustrated. We have seen, in Zosterops, some indications of a climbing structure, and ill one species a lengthened and very slender bill; these characters, although they by no mcans prepare us for the fifth type of Sylvieola, will reuder the transition to the Mniotiltu vuria Vieil., or black and white creeper of North America ( $f i g .132 . a$ ), less abrupt than it woukl otherwise

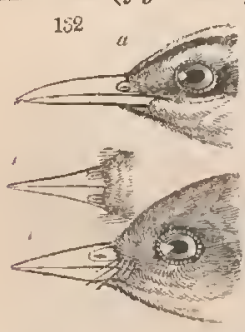
appear. This bird, in our systems, lias shared the fate of numberless others, presenting a union of apparcnt contradictory characters. Although a scansorial bird, like several others in this family, its true affinitics unquestionably lay with the Syluicola: : its bill, although somewhat lengthened, is notched, and formed on a similar model ; so also are its wings and tail; its plumage likewise is totally devoid of those colours so universal among the true scansorial creepers, Certhiada. But even adinitting all this, it may be urged, in what manner has nature connected this bird with the Vermivore, or worm-eating warblers? for this affinity is absolutely necessary to complete the circle of the genus Sylvicola? In reply to this, we must direct the reader's attention to the peculiarly interesting eco- 
nomy of the pine creeping warbler ( fig. 132. $b$ ) as thus narrated by the ornithologist of Amcrica.

(53.) "The pine creeping warblcr," says Wilson, "runs along the bark of the pines; sometimes alightingand feeding upon the ground, and almostal ways, when disturbed, flying up and clinging to the trunks of trees. They associate in flocks, and are easily known by their manner of rising from the ground, and alighting on the body of the tree : they also often glean among the topmost boughs of the pine trees, hanging head down wards like the titmouse; but, notwitlistanding the habits of the birt, the tongue is slender, as in the warhler genus." $\Lambda$ gain: "The pine warbler has all the habits of a creepcr, alighting on the trunk of the pine trees, ruming nimbly round them, and, according to Mr. A bbot, builds a pendulous nest." + Here, then, is a bird presenting as extraordinary a union of characters (in themsclves apparently contradictory), as any in this class of animals. It climbs with all the facility of a scansorial creeper, yct, unlike that family, it is gregarious and builds a pendulous nest: it has the tongue of a warbler, but the habits of a Vormivorn and a Parus. It frequently feeds upon the ground, in flocks, like the gallinaceous birds; but yet it ascends the highest trees, and hangs to the branches like a titmouse! Finally, the bill of the bird (fig. 132. I) (the two sexes are now before us) is precisely like that of Vermivora, equally entire; but the culmen is very slightly arched, and the base somewhat depressed. It further exhibits the remarkable character of the rictus being distinctly bristled: to this latter character we shall subsequently call the reader's particular attention.

(54.) Let us now inquire low far the above peculiarities almit of explanation. The affinity between the black and white creepcr (Mniotiltu varia) and the pine creeper is manifested not only by the foregoing account, but by the similar construction of their feet, wings, and tail; both birds, indeed, have been placed together by the able elucidator of $\Lambda$ merican ormithology, prince

* Am, Om, vol, iii. p. 25.

VOL. II. 
Charles Bonaparte. The connection of the pine creeper with Vermivora is still more indisputable: like those birls, its nest is pendulous; its tongue the same; its bill is equally entire, and nearly as straight; the elongation of the hind toe is intermediate, in degree, between that of the black and white ereeper, and of the Vermivora solitaria. Finally, its plumage and general aspect so closely rescmble the latter bird, that nearly all luropean ornithologists have actually mistaken the one for the other! 'The affinity, therefore, between the pine creeper and Mniotilta varia on one side, and Vermivora on the other, bcing now established, the circle of the whole group is made out.

(55.) But we must carry this analysis further. The five types we have now enumerated should, according to the theory we hold, be capable of a primary solution into three; that is, the three that are aberrant should form one circular group: the question therefore is, what are the indications of a circular union between Dumecoln, Zosterojs, and Mniotilta? We have already alluted to the rigid bristles round the bill of the pine creeper. Now, this very singular character can only be explained by looking to the Dumecola ruficauda Sw., or any of the other undescribed species of the same group, where we find the rictus similarly formed; a peculiarity of organisation, be it remembered, which is not found in any other birls of this group: agrain, Dumecola, if truly connected with Mrniotiltn, should have some indication of the scansorial structure, although its depressed and bristled bill makes it the true type of the flycatchers and the todies; now, this indication is not ouly very strong, but particularly beautiful. The hind claw of Dumecola, although not so lengthened as that of Mniotitta varia, is fully as long as that of the pine creeper; the claw is also particularly large: the rufous sail of $D$. micauda, so universal anong the true scansorial creepers, immediately reminds us of thsoe birds; and this analogy is still more evident, on observing that all the feathers end in five naked length- 
ened points, In this manner, every part of the structure of Dumecola muficauda can be explained, and the circular union of the tliree aberrant subgenera of the Sylvicola is effected.

(56.) In testing the correctness of the foregoing views on the subgeneric types of the genus Sylvicola by means of the following table of their analogies, we may solve one or two important questions resulting from the economy of the pine creeper (MIniotilta pinus), which may still appear unexplainel. The atten-. tion of the ornithologist is therefore called to the following table, intended to illustrate the relations of the whole group.

\section{Analogies of the Genus Sylvicora.}

Sibbenera of Sylvicola.

Analogical Charactcrs.

Vermivora. Sylvicola.

Dumecola. Zosterops. Mniotilta.
Bill lengthened, conic, entire, or nearly so.

Bill notehed a little way from the tip.

Bill bristled and depressed at the base.
Tribes of the Perehers.

(57.) By this table, the close resemblance of Zosterops, both to the small Australian honcysuckers, and to the genus Diceum, is immediately explained; since it is by this type that the tribe of Tenuirostres (to which those suctorial groups belong) is actually represented. Mniotilta, as typifying the seansorial birls, should also possess some analogy to the Rusores; and thus we arrive at an explanation of the gregarious econoiny of the pine creeper (Vermivora pinus), and of its singular habit, although a scansorial bird, of ferding also upon the ground! So true it is, that an acquaintance witl the station which any being actually holds in nature, will generally revcal the true meaning of that perplexing union of opposite characters so frequently found in a single species: anomalies, indeed, which "laugh to scorn" the speculative theories of man, but which, upon patient investigation, display an orter and a regularity in the great plan of nature, at once 
surpassingly grand and wonderfully minute. The other analogies in this table are too obvious to require pointing out.

(58.) Let us now compare the subgenera of $S y L$ vicola with those of Parus. It will be remembered, that these two are the typical groups or genera of the subfamily Pariano, and that each contain five subgenera. Now, if these are disposed in their natural series, each of these subgenera will mutually possess a strong and peculiar resemblance to each other, so that, in fact, the subgenera of Sylvicola will contain representations of the subgcnera of Parus. To this test, every group or genus, thought to be natural, must be brought. Now, that this is not only true in regard to the birds in question, but wonderfully regular and beautiful, when developed, the ornithologist will perceive, on studying the following table:-

\begin{tabular}{|c|c|c|}
\hline $\begin{array}{l}\text { SrLvigol, } \\
\text { ubgenera. }\end{array}$ & Analogies. & $\begin{array}{l}\text { Panus, } \\
\text { subgenera. }\end{array}$ \\
\hline TERMVORA. & $\left\{\begin{array}{l}\text { Bill lengthened, conic, very acute, entire; } \\
\text { rictus smooth. }\end{array}\right.$ & \\
\hline SYLYICOLA. & $\left\{\begin{array}{l}\text { Bill shorter, much complressed; rictus with } \\
\text { weak bristles. }\end{array}\right.$ & \\
\hline Duatecola. & $\left\{\begin{array}{c}\text { Bill depressed; feet lengthened; rictus } \\
\text { bristled; wings rounded, }\end{array}\right.$ & \\
\hline Z OSTELOPS. & $\left\{\begin{array}{l}\text { Bill gradually pointed, notehed remotely } \\
\text { from its tip; hostrils naked; the aperture } \\
\text { linear; foet strong. }\end{array}\right.$ & Hri. \\
\hline MRIOTILTA. & 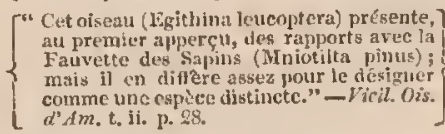 & EgะTnina. \\
\hline
\end{tabular}

(59.) To pursue this subject further would be almost needless, since the test we have thus applied to the contents of both groups, demonstrates their natural arrangement. By referring to the preceding table of the analogies of the five subgenera of Sylvicola, the naturalist will perceive that, in these two genera, nature preserves the same laws by which she has regulated her primary divisions of matter. We have in each three primary circles, which, when compared with the three 
primary groups of birds, are found to correspond. But if we merely admit that the first division is into five, and not three, we still have the same results : not only are the five orlers of birds and the five races of the perchers (Insessores) clearly represented, but also the five families of the Dentirostres, the five subfamilies of the Sylviada, and the five genera of Parus completely typified. Finally, we sec the five subgenera of one group beautifully represented by those in the other. With regarl to the analogy between Mniotilta and Egithina, the testimony of M. Vicillot appears to us conclusive. It is; indeed, not a little remarkable, that he should, in the first instance, merely separate Egithina leucoptera, as a species, from Mniotilta, and that, subscquently, he should characterise it as a distinct genus.

(60.) The genus Sylvicola is immediately followed by that of Setophuga, comprising the flycatching warblers; and to these, the subgenus Dumecola Sw. opens an immediate passage. The group now before us has many striking peculiarities. In the first place, it contains birds which have long been arranged in popular systems with the tme flycatchers, from which, however, they are decidedly scparated by the length of their legs and the structure of their wings. For the latter we have been prepared, by the more rounded wings of Dumeoola, where the first (and often the second) quill is graduated, and slightly shorter than the third; while the length of their feet, and the general structure of these members, at once indicate that they are usel and adapted for constant exercise. Like all the titwarblers (Sylvicola), the Setophage hunt for flying insects from bough to bough; they are, in fact, fly hunters; and thus differ most essentially from the true flycatchers, who watch for their prey in a serlentary position, and only seize it when it comes sufficiently near. The most typical examples of this singular group are from Mexico, and have hitlerto only been noticed by us in a brief synopsis on the new birds of 
that region: one of these, the beautiful Setopluga picta, we have since figured in Zool. Ill. od series, pl. 2. The American rerlstart of Wilson may, for our present purpose, be looked upon as the type, or at least as that example of the group most familiar to oruithologists, and whose mammers have been fully illastrated by Wilson. All the species yet known to us are natives of the more extra-tropical regions of America. In a new one, now upon our table, from the interior of Brazii, we find the legs more than usually lengthened; the tail and wings shorter, and the bill narrower; the length of the feet clearly showing that the bird must frequent the ground. We refrain, however, from offering any remarks upon the circular distribution of this group, since two of the types at present are unknown to us. It is represented, among the tiue flycatchers (Muscicapine Sw.), by the Australian fantails ( $R h i_{-}$ piduru $H_{\text {. and }}$.), with which, as usual, it has been erroncously supposed to have an affinity.

(61.) To the genus Trichas, or the yellow-throuts, we are conducted by the bird just alluded to. Of this group, only two species are yet known; one is the Sylvia vclata of Vieillot*, the other the Maryland yellow-tliroat of Wilson (Trichas personatus Sw.). These birds, unlike all those of the precelling groups, live habitually upon the ground, and appear, from Wilson's account, to lave the same manisers as the winter fauvettes of Europe (Accentor). Let the naturalist, therefore, perusc the account which Wilson gives of the Maryland yellow-throat, and, without any further information, he will limself pronounce that it might almost have been written to describe the peculiarities of our common helge sparrow, or fauvette, the Accentor modularis of Cuvier.

(62.) The subfamily of Sylvicoline is thus seen to form a connected circle, which we have traced through the gencra Accntor, Parus, Sylvicola, Setophuga, and Trichas. We have further shown,

- Tan, canicapilla, Zool. Ill. iii. pl. 174. 
that Sylvicola contains within itself five smaller groups, first resolvable into three primary ones. That there is strong rcason to suspect a similar union of the three aberrant genera of this subfamily, namely, Setophaga, Trichas, and Accentor, is apparent from the fact, that Setophaga rubra, although certainly belong. ing to this genus, departs so much from its type, that, with a strongly bristled rictus, it has the completely pointed and compressed bill of Seiurus auricapillus, - a bird which should more properly he placed with Accentor. Further, we have recently cxamined a new Setophaga, from Mexico, exhibiting the black striped head, and the tawny crown of the last-named bird. With these close approximations, one, or at most two, species would connect the aberrant Sylvicolince into a circle; and we consider this evidence is sufficiently strong to warrant the assumption that such is actually the case in nature.

(63.) The following table of analogies, condensing the result of the foregoing investigation, will explain the relations subsisting between the genera of the Sylvicolince, the types of Sylvicoln, and the tribes of the perching-birds : -

Subgenera Genera of

of sylvicola. the Parianil.

Srrvicola. Srivicola.

Vermivora. Patús.

Mntotilta, Accentor

Zosterops, Thichas.
Analogies.

Tribes of $\mathrm{In}$ sessores"

Dentinostres.

Dumecola. Setropiaga. $\left\{\begin{array}{c}\text { Bill depressed; take their } \\ \text { food on the wing. }\end{array}\right\}$ Eissunostres.

(64.) On attentively studying the above table, the only point upon which we do not feel fully satisfied, regards the situation of Trichas; or, rather, relates to a suspicion that Trichus is not the genuine type of that genus which is to represent, in this subfamily, the Tenuirostres. True it is, that there cannot be the least doubt that Trichas intervenes between Setophaga and 
Accentor, since the links connecting all three are nearly filled up. Our suspicion, therefore, is merely excited by our total ignorance of the manner in which nature passes from 'Trichas into the Ampelide, or fruit-eaters; since, if this is the next family, its junction with that of the Sylviadce may be supposed to take place at this point. On the other, hand it must be remembered that many of the most indisputable passages or transitions in the ornithological system take place through groups which are terrestrial ; and, as Trichas is strictly of this description, it is contrary to sound logic to doubt that which is known, from our ignorance of that which may be unknown.

(65.) The intimate connection between Setophaga and Sylvicola enablcs us, in this place, to illustrate our views on one of the properties of typical or external groups. We have alrcaly had occasion to remark, that Mr. MacLeay long ago pointed out the rescmblance which such groups as these, in two or more different but contiguous circles, bear to each other; and this resemblance he has termed analogy. Now, this term appears strictly correct, when the groups in question are vcry comprehensive, and the intervening forms very dissimilar. If, for instance, we look to the two typical divisions of vertebrated animals - as quadrupeds and birds - and compare thent with the corresponding groups of the Annulosa, or insccts, we immediately perceive that there may be an analogy, but that there cannot exist any possible affinity. But how stands the case when the groups to be compared are smaller? Let us look to the circle of the Pariana to illustrate this question.

(66.) The typical genera, as seen in the annexed diagram, are Parus and Sylvicola; the subgenera Yarus and Egithalus in one, and Fermivora and Sylvicola in the other, are consequently the external or typical groups. Now, in support of our opinion, that what are to be termed analogies in larger groups, insensibly change their character, and blend into close affinities in smalle groups, we appeal to this circle. Is not the resem- 
TYPICAL GROUPS CONNECTER.

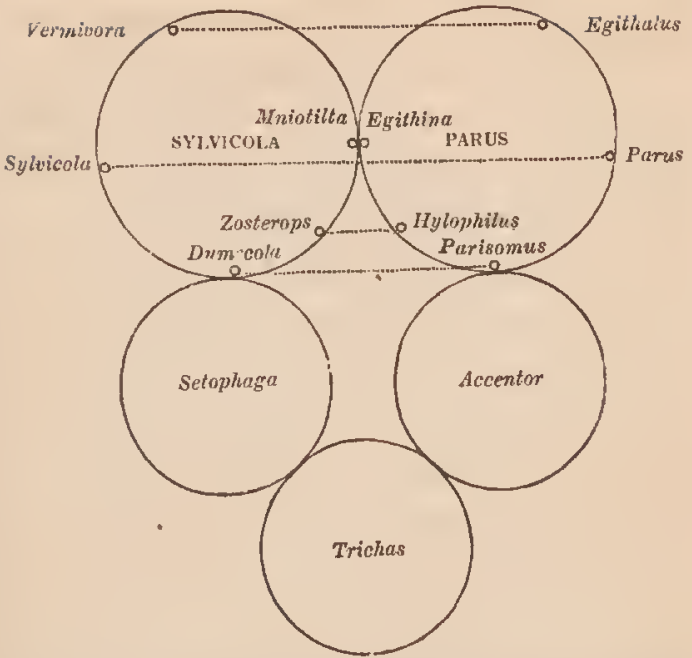

blance (we will neither term it analogy nor affinity) between Egithulus and Verminora fully as strong as that between Mniotilta and Egithina? We should certainly say it is: again, supposing neither Mniotilta nor Egithina had been discovered, and we had no suspicion that such forms existed, in what manner should we suppose that the genera Parus and Sylvicola were united by direct affinity? In such a case, we should undoubtedly point to Vermivora, as passing into Parus by means of Egithahus. So close, indect, is the resemblance between the two, that nothing but a slight difference in thcir wings and feet scrves to scparate them. Can tben a resemblance, which, in such a case, is sufficiently strong to constitute an affinity, be termed a mere analogy? we think not: on the contrary, we believe, that in proportion as we contract our views, and investigate the nature of the typical or external groups in small circles, we shall find they follow each other in absolute affinity. It is needless, however, to 
repeat our opinions on this intricate question: let us rather illustrate it by the testimony of others.

(67.) We have seen that Setophaya and sylvicula, notwitlistanding their intinate rescmblance, stand in two different circles, which circles arc connected by the subgenus Dumecol $a$ : their relation, therefore, according to the vicws of Mr. MacLeay, are merely analogical; not because this relation is less perceptible than that between Sylmieola and Dunecola, but because the two groups stand opposite to each other in different circles. Now, setting aside the usual mode of distinguishing affinities from analogies in larger groups, it must bc at once adınitted, that when the differences between two given groups are so imperceptibly graduated and softened down by intervening species, that it is utterly impossible to discover one. link that is impcrfect in the chain, then such a relation becomes unquestionably onc of absolute and direct affinity. To demonstrate, therefore, that this is true in regard to Sylvicola and Setophaga, we shall cite the authority of Wilson, a man totally destitute of theory, lut who watcled and studied these birds in thcir native haunts. Let us take the Sylvicola Americann, the blue yellow-backed warbler of the Amcrican Ornithology (4 pl. 28. f. 3.), as the best and the most familiar example of the true Sylvicolo; we see the bill ( $f \mathrm{~g} .133 . a$ ) compressed on its sides, and, although wider at the base,
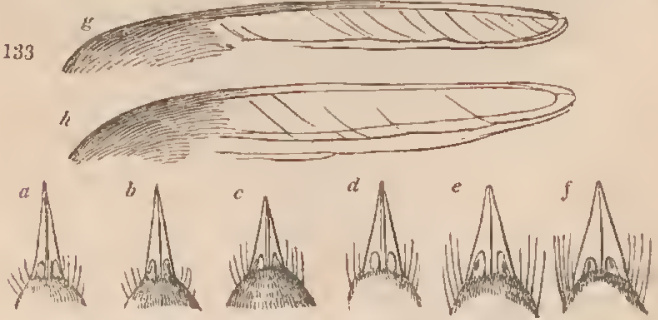

still the breadth is not greater than its height: the bristles of the rictus are short, and do not extemd. 
beyond the length of the nostrils : the first quill $(g)$ is scarcely perceptibly shorter than the two next: the tail is very slightly forked, or rather divaricated. This, in short, is the typical structure of the group: as we procecd, howcver, in the serics of species, we trace a slight increase in the breadth of the bill. This is very observable in the Sylvicola canntensis (b), upon which Wilson makes the following remark: "Though the form of the bill of this birl is decictedly that of a warbler, it has much of the flycutcher in its manners." The Sylvicola coronatu advances us a step further (c); and accordingly, Wilson remarks, that "although the bill of this species obliges me to arrange this hird with the warblers (Sylvicolit), yet in his food and all his motions he is decidedly a flycatcher." Again, on the blackpoll warbler (S. striatu), our author writes, "This bird may be considered as occupying an intermediate station between tlie flycatchers (Setophaga Sw.) and the warblers (Sylvicoli Sw.) ; having the manners of the former, and the bill, partially, of the latter." The change gradually continues, until finally, upon reaching the hooded flycatcher (d), the most aberrant form of our genus Setophagu, but which is a Sylvia (Sylvicola Sw.) both of Vieillot and Bonaparte, our author bursts out with the following exclamation:- "Why this bird should have been arranged with the warblers (Sylvicola) is to me unaccountable, as few of the Muscicapa (Setophrogn) are inorc strongly marked than the species now before us; it is perpctually in pursuit of winged insects." Now, in what respect does this birl differ, in its external structure, from the Sylvicola americana? simply in having the bill somewhat broaler at the base, and the bristles extending to half the length of the bill; the wings, the feet, and the tail, are preciscly the same, with this exception only, - that the two outer feathers of the tail are very slightly graduated, and shorter than the otliers. The next link is furnished by Setophagn canndensis $(c)$, where all the tail feathers are graduatcl; and this is immediately followed by the type 
of the group, Setophaga ruticilla $(f, h)$, or the American relstart of Wilson, which every author, who has mentioned the bird, admits to be a flycatcher.

(68.) Such, then, is the scries by which Sylvicola and Setophaga are united; and it has been marked out by one who had ueither a system to propound, nor a theory to support. It is, indeed, most interesting to find that this thread of nature has heen followed up with such admirable precision hy one who has been aptly termed a field naturalist : for ourselves, we can only add, that every one of thesc changes in the habits of the spe-cies here enumerated, is marked by a corresponding difference in some part of their external structure.

(69.) The connection of Setophaga with sylnicola being thus established, it remains to be considered if the first of these groups holds that rank in the circle of the Pariance which we have here assigned to it - that is, of a genus; - or whether it is in fact but a subgenus of Sylvicola, really occupying the station we have given to Dumecola. The solution of this question is exceedingly difficult; and, although it has occupied our attention for many years, we by no means feel that conviction of the accuracy of our present dccision, which we do on many other analogous instances. This we unequivocally mention, that those ornithologists who may hereafter have time and opportunity for going orer the same ground may not attach undue weight to our opinions. We consider, then, that this is a perfectly analogous case with the affinity between Thamuoplihus and Myothera, both of which are external genera in two different circles, but which do not immerliately follow each other in the same circle. Both, in short, seem to be instances of the strongest external affinity, or of that relation, which in larger, and therefore more dissimilar, groups would be termed only an analogy. We are induced to form this conciusion regarding the two groups immcliately before us, not so mucli from the perfect analogy which the case bears to others, but because Sylvicola appears to be $a l$ most as closely connected with Dumecola as it is to Seto- 
phaga. We have therefore to choose one or other of these relations for connecting Sylvicoln with Zosterops: and as Dumecola shows a much stronger resemblance to Zostorops, than does Setophaga (which, indeed, seems to have none), we ground our decision on this especial point of argument; more particularly as Setopkaga, although it seems to have no intimate connection to Zosterops, has yet (in some undescribed species before us) a most palpable affinity to Trichas. The situation of all these groups will be apparent in the diagram we liave already given of the Puriane (p.57.). But admitting, for the sake of argument, that Dumecoln had nothing to do with the present group, and that it is ultimately proved to belong to the true Tyrannula (an affinity which is barely possible), still even this would not effect any change in the situation of Setophaga, for this especial reason, that this group is unquestionably related most intimately to Trichas, - an affinity which, if once violaterl, throws the whole division of this otherwise most heautifully arranged sulofarnily into perfect disorder and confusion.

(70.) We enter ainong the true warblers (Sylviana) by the genus Cuticivorn, or gnat-snappers, - a group of delicate hittle birds, having onc half of the bill, as in Setophaga, depressed, and the other half, as in Sylvia, compressed. This group is limited to America; and so much do tlicir manners rescinble those of the flycatchers, that Wilson describes the principal spcciesas a Muscicapu. From these we pass to the pre-eminently typical group of the whole family, the restricted genus Sylmin, in which are the golden-crested (fig. 134.), willow, and wood wrens, -a

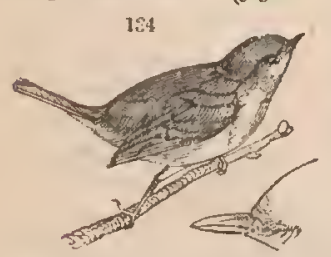
popular, although by no ineans a correct name, inasmuch as all these birds are typical examples of the whole family : this passage is effected by certain Setopluge of Brazil, which, by their size and golden coloured crests, so much resemble those of Eurone, that the depression of their 
bill is their only prominent distinction. From the diversity of form among the birds composing the typical genus Sylviu, we sispeet that the subgencra may eventually be deteeted: thus, the wood and willow warblers exhibit several points of variation from the gold crests. By the subgenus Acanthiza, eomprising such birls of New Holland as there represent the typical Luropean warbleıs, we are eonducted to the soft-tailed division, or the genus Malurus Vieil. To this group, we suspect, belongs the Dartforl.warbler, the only British, or indeed European, example. The texture of its feathers is very open, and the tail is more particularly long and soft. Several speeies inhabit Africa; but the most beautiful come from Australia, where we have the superb warbler, and several others, richly ornanented with vivid blue and velvet black plumage. To these snceed the wren-like warblers of $A$ frien, forming the genus Drymoica, and of which Prinea may be a subordinate type or subgenus. 'These latter birds have all the aetivity and familiarity of the true wrens (Troglodyles), and so much reseinhle them in general appearance, in their short sweet song, and the throwing up of the tail, that it is not very surprising they should have been classed with the scansorial creepers. The fiftl gemus, or type, which should represent the Tenuirostres and the Grallatores, has not been clearly made out; although it may possibly be the genus Orthotomus Horsf., since this form has a most unquestionable affinity to Prinea, and in the depression and compression of its bill seems to appronch the gnat-snappers ( $\mathrm{Cu} / \mathrm{i-}$ civora); the type of Orthotomius is not, however,

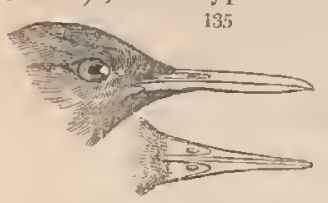
the bird deseribed as such, but the Dicea a longue bec of the Paris Museum (Orthotomas longirostres Sw.), the head of which ( fig. 135.), of the natural size, is here given from a lrawing made from this specinien, the only one yet known. The union of the three aberrant genera, namely, Drymoica, Orthotomus, and Culicivora, seems 
effected by certain Indian species of Drymoica which have the depressed and bristled bill of Culicivora.

(71.) The analogies which the preceding five genera exhibit to the tribes of perchers are singularly interesting, since we find that Drymoica and Prinea represent the scansorial birds, and, consequently, the common wren of Europe. In Orthotomus, we have the long bill of the Tenuirostres, with the lengthenerl feet of the genera Trichas, Agrobates, Anthus, and Motacilla. "The situation of the subgenus Apalis" is somewhat doubtful, but it may probably belong to Orthotomus. Culicivora, with which we bcgan this subfamily, from its resemblance to the true flycatchers (Muscicapida), is clearly the fissirostral type.

(72.) The P'nuonelin w, or nightingale warblers, form the fourth great division of this family. It contains the nigltingale, the reed and sedge warblers, and many other of our summer visiters. The general size of these birds is larger, and their structure much stouter, than those we liave just quitted; while the true warblers feed only upon insects, and thereby rescmble the rapacious birds, the uightingale warblers, like the thrushes, subsist equally upon fruits, and still further typify that family in the well-known melody and strengtli of their song. 'The first genus which presents itself' is Curruca, while Philomela, Phonicura, and Agrabates, are the only genera we have yet made out: the fifth is probably represented by two or three extraordiuary flycatching warblers, shown to us by M. Ruppell, as part of lis recent discoveries in $\Lambda$ byssinia, and which he erroneously thouglat belonged to the $\Lambda$ ustralian genus Mowacha (Drymophila Tem.) 'The sedge warblers of Europe (Curruca) form a large and interesting group, containing several minor divisions or subgencra, whose natural affinities require much study. Marshy thickets, reedy banks of rivers, and sinuilar humid situations, are the favourite haunts of these plain-coloured birds. The nightingales (to which we now restorc the classic name

* Zool. III. ii. pi. 119. 
of Philomela) represent the typieal perfection of this subfamily: their own particular circle has not been worked out, but it will comprise not only the niglitingalc, but the white-throated and the black-capped warblers of Britain; these latter assuming much of the appearance, while they are perfectly analogous to the tits (Parus). From these we pass to the genus Phanicura Sw., familiar to every one by the frequency of our native example the redstart ( $\mathrm{fg} .136$.$) ; nearly all the species, in$

136

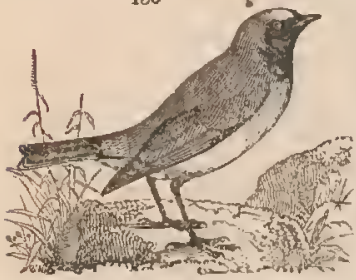
fact, have the tail of a bright chestuut or rufous colour. The tenuirostral type appears to us to be represented by the Sylvin grlactotes of Europe, which is evidently a walking bird, and perfeetly analogous to Furnarius, Motacilla, and the other long-legged warblers representing the Grallatores.

(73.) The analogies which may be traced between this group and many others, are no less striking than those of the last. 'They are, in fact, so numerous, that we hardly know where to select our illustrations: the best, perhaps, will be to compare this with the neighbouring group of truc thrushes: we thus find the nightingale represented by the famous mocking bird of Anerica (Orpheus); the Currucn Mcruloüdes Sw. by the typical thruslies; and the red-tailed rock thrushes (Petrocincla), by the red-tailed redstarts. Again, on looking to the Sylviana (the subfamily we have just quitted), we see the soft tail of Mralumes transferred to the reed warblers (Curruca), while the wood wrens (Sylvia) and the nightingales arc both characterised by even tails: the broad rounded form of this nember, in Culicivora and Plonicura, is another very curious analogy; and the resemblance of Agrabates to Furnarius is obvious to every ornithologist.
(74.) The SAxicolins, or stonechats, represent the 
fifth subfamily. These, for the most part, are solitary and shy, living on heaths, moors, and desert plains, where they are generally secn pursuing insects upon the ground. This economy, so totally different from all the warblers we have hitherto noticed, is accompanied by several peculiarities of structure: the legs are very long and muscular; while the bill, as in all birds which live upon winged insects, is broad at the base, and provided with

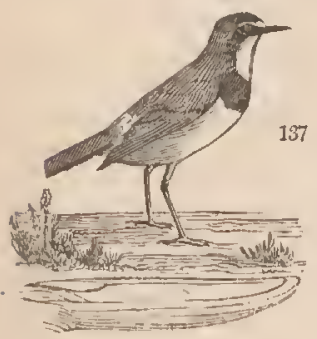
weak bristles, to confine the struggles of their prey. 'The Suxicolce (S. pileata, fig. 137.) proceed by running very swiftly, and thus imitate the wagtails, which proceed in the same manner, and the swallows, which skim the surface of the ground by flight. The stonechats, properly speaking, are birds restricted to the Old Continent, and we have three examples of the group in England, viz. the white-rump, or wheatear, the whinchat, and the stonechat. The first indication of their habits is seen in the

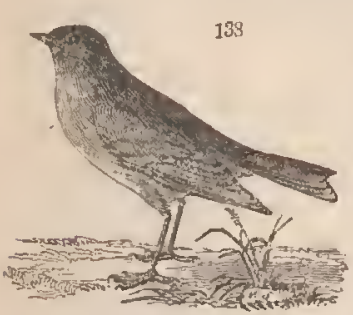
common redbreast (Erythace rubecola Sw., fig. 138.) which thus forms a passage from the redstarts: close to this well-known species must be placed, as subgenera, the American blue-birds (Sialia Sw.), and the Australian robins ( $\mathrm{Pe}$ troïca Sw.); from these to the true stonechats (Suxicola Bech.), the passage appears very gradual; while the genus Thamnolia, now first defined, learls us to the stronger and more hook-billed genus Gryllivora.

(75.) The fifth, or grallatorial genus of the Saxicovor. II. 
line is involved in much obseurity. We had long entertainer the belief, that the baker-birds of South Ameriea (Furnarius Vieil.) naturally filled this station, partieularly as a new species has of late years been diseovered, having a red breast; thus resembling the robins in eolour, although not at all in structure. On the other hand, the resemblance between l'etroïcn bicolor and the genuine loeust-eaters (Gryllivora) is so remarkably strong, not only in colour, but in form, that we think the two groups eannot be separated by one so dissimilar as that of Fumarius. In the subsequent pages, we have charaeterised what appear to be three distinct speeies of Gryllivora, hitherto confounded under the eommon nanie of $G$. suularis: let the ornithologist eompare these with the fetroica bicolor, and he will, no doubt, adopt the opinion we here express as to the

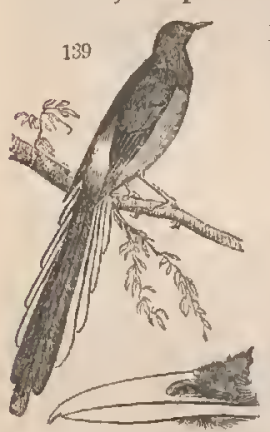
affinity of the two genera. The long-tailed loeust_eater (Gryllivora longicauda, fig. 139.) seems to be the sprecies which conneets the stonechats with the wagtails, for ic has the general structure of Gryllivora, with the pale and slender legs of Enicurus.

(76.) The union of all the subfarnilies of the Sylviade, which we have now gone through, is affected by the Gryllivore, the genus just mentioned, annong the Saricolina, uniting to Enicurus, which stands at the confines of the wagtails (Motacillince). As all naturalists agree in plaeing Enicurus close to Motacilla, nothing need be said on that affinity; while the strong resemblance between the bills of Enicurus (fig. 140.b) and Gryllivora (a), - both also having the wings and the feet formed nearly on the same model,-leaves no doubt on our mind of an absolute affinity between them.

(77.) Having now traced the great circle of the * Zool. Ill. il, pl. 43. 
Sylviadce through all the subfamilics, and many of the

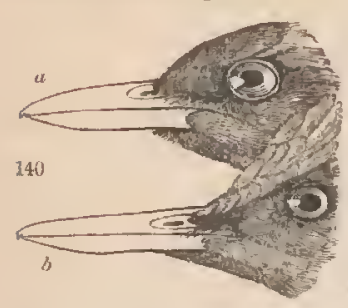
inferior groups, we shall encleavour to explain in what manncr the three which are aberrant become united. This union is fortunately so perfect, that we can dismiss the subject in a few worls. The Australian genus Petroica, as we haveal rearly shown in another place* is the southern representative of our robin; the legs are, nevertheless, weakcr, and the bill so much depressed, that all ornithologists have classed these birds as $\mathrm{Ay}-$ catchers: all, thcrefore, that is necessary, to connect the robins with the fantailed flycatchers of America (Setophaga $\mathrm{Sw}$.), is a bird which still preserves the general form of Petroica, but which has the smaller and weaker feet of Setophaga: now, such are the true characteristics of the Australian Petroica Lathami. So much, indeed, does it depart from its own type, and touch on the American, that, but from the most minute examination, joined to a knowledge of its country, we should be quite. at a loss to which group it belonged: this affinity is even marked in the most conspicuous manner by the colours of the two groups. The orange-red of the robin clianges in the Petroica multicolor to a full crimson, but the belly is still white. In $P$. Lathami, the whole body is rich pink, and the white frontal spot of the former species is very small. In Sctopherga miniate Sw., this spot totally disappears, but the whole borly is still bright red; and this colour is still continued to Setophaga picta $\mathrm{Sw} . \mathrm{t}$ : thus not the slightest interval occurs between the types of botl groups, although the onc belongs to the Saxicoline, the other to the Pariane.

(78.) Lct us now look to the analogies bctween the five subdivisions of the grcat family of warblers,

* Zool. Ill, 2d series.

+ Zool. III. ii. pl. 1. 
and the five tribes of perching birds: we shall first place them in the following order:-

Syuviaba., - The Analogies.

Tribes of the Perchers.

Typical Characters.

Subfamilies of the Warblers.

Coxנrostres. $\quad\left\{\begin{array}{c}\text { Bill slightly notched; the most perfect } \\ \text { in their respective groups, }\end{array}\right\}$ sylviane.

DEnTirostres, Bill more dlstinetly notched.

Fissirosties, Bill depressed; the base bristled.

Philomelince.

TExiluostres. Bill very weak; rictus smonth.

Suxicolina.

SCANSOREs. Climb, and seek their food in trees.

Motacilline.

Pariona.

By this table we get some of the most prominent distinctions of both groups. The two first analogies, as may be expceted, are very remote; but the three next are so lecided, that they must strike every reader. Who that has seen the stonechats rapilly coursing over a common, in pursuit of winged inscets, is not immediatcly reminded of the swallows, which do the same upon the wing? Both groups arc particularly remarkable for the great size of their heads, and the broad base of their bill; characters universal among all natatorial and fissirostral types. The Motacilline, or wagtails, have the bill unusually slender, and thus represent the wading order; and the haunts of both are always in the vicinity of water. Every onc has seen the adroitness with which the tomtit clings to the smallest branches of trees, examining every bud, pecking at every hole, and indefatigably senrching for insects hid in such concealments. No other birls have these manners but the woolpeckers; and this resemblance extends even to the bill, which in both is strong, pointed, and entire.

(79.) But it may be said, that the stonechats as much resemble the gallinaceous order as they do the Fissirostres, since like them they are continually upon the ground, and, in proportion to their size, have the legs equally strong. Let us, therefore, draw up a second table, in which these two groups are placed opposite each other:- 
SYIVIADAE. - THEIR ANALOGIES.

Orders of

Birds.

RAPTOREA.

INSESSORES.

Rasores.

Graulatones. Tenuirostres.

Tribes of Perchers.

Analogies.

Subfamilies of Warblers.

Dentirostres. Feed only upon animals. Sylviache.

Conirostres. $\left\{\begin{array}{c}\text { Feed on animals and ve- } \\ \text { getables. }\end{array}\right.$ Philomelina.

Scansores. $\quad\left\{\begin{array}{c}\text { Terrestrial, living on the } \\ \text { ground. }\end{array}\right.$ Saxicolina.

Natatores. Fissirostres.

$\left\{\begin{array}{c}\text { Bill very slender; fre- } \\ \text { quent the vicinity of } \\ \text { water. }\end{array}\right\}$ Motacilline.

(80.) On looking to this second table, it is somewhat singular, that notwithstauding the analogies of the two first subfamilies are made to appear as reversed, that they should still possess properties which enable them to be comprarcd with either. Indeed, the resenblance between the Sylviance and the Myotherina (which latter truly typify the Dentirostres) is so particularly strong, that we liave not a doubt they mutually represent each other in their respective circles. The only question is, how, with this strong analogy between themselves, they can at the same time represent two different tribes of the perchers? The nightingales (Plilomelina), in like manner are the unquestionable prototypes of the true thrushes (Meruline); and as these latter certainly represent the Conirostres in their own family, how can the former be also compared to the Dentirostres? The only way at present in which we can account for this transportation, if such it be, is by the property belonging to typical groups of exhibiting more than one analogy; and that a group, for instance, which is the representative of the Dentirostres in its own circle, may yet represent another group in another circle, whose true analogy is with the Conirostres. Certain it is, that, however strong the resemblance may be between the four first scries of this latter table, the last is so very obscure, that our suspicion is excited; and we immcdiately perceive that however ingenious, it is, as a whole, but a false and delusive table. The analogy of the Puriuna to the scansorial order is too obvious to be questioned for a moment; and therefore 
any table of supposed analogies, however ingeniously contrived, where this direet relation is destroyed, mus be radieally false.

\section{CHAP. VT.}

THE DEATIROSTRES CONTINUED. - THE FAMLY OF AMPELJDE; OR CHATTERERS.

(81.) Wr now arrive at the second aberrant group of the oreler. It is composed of the AMPELID\&, or chatterers, so named from the loud aud inonotonous notes of sone of the species. It is a farnily more remarkable for beauty and singularity than for its extent; hence much diffieulty has arisen in making out the subordinate divisions and the succession of its groups, just as the disjointed parts of a machine can seldom be fitted together when many others are wanting. The ehatterers are very loeally distributed, for all the prineipal types belong to the

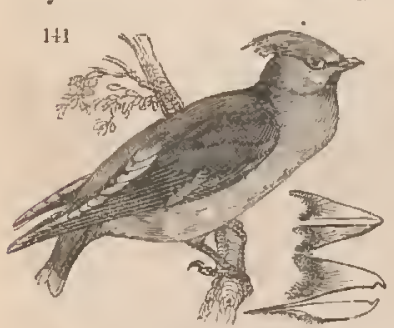
tropical parts of America; one only, the $B o m$ bycilla gorruln, being found in Europe. "l'hey are distinguished from all others of the Dentirosires, by the enormous wirlth of their gape, which in many cxtends beyond the eye, and in some is nearly as wide as that of a goatsucker. The particular use of this strueture is at once explained by the nature of their food: they live almost entirely on soft berries and small fruits, which, from being swallowed whole, naturally requires a very wide passage to pass down the throat: a broad bill always indi- 
cates weakness, and when the sides of this important member are not defended by bristles, we may feel assured that insects, or at least those which are capable of much resistance, form no part of the food. This is truly the casc with the chatterers, whose nourishment is derived almost exclusively from the vegetable kingdom. They are perpetually hopping among fruitbearing trees, and seem to know, by a wonderful instinct, the period when each species yields its berries: they never perch upon the ground; the feet are consequently either very short or very feeble, and as their structure is adlapted for grasping boughs, the soles are broad, and this brcadth is increased by two of the toes being more or less united. The naturalist will discern in all these peculiarities, many points of analogy to the orioles, the plantain eaters, and the tribe of Tenuirostres, all of which are represented by the family before $11 \mathrm{~s}$.

(82.) That the chatterers follow the warblers, there can be no reasonable doulvt; secing that their alorrant genera liave many strong points of resemblance to those birds, while the typical examples are perfectly analogous to the caterpillar-catcliers (Cellepyrina), the orioles, the Paradise-birds, and all the other fruit-eaters. Without, therefore, seeking to determine the precise point of union, we shall at once procecl to notice the subfamilies under which the lifferent genera appear to be arranged; these we rlesignate as follows:-1. Leintrichunc, or long-legged chatterers; 2. Puchycephalinu, or great-headed chatterers; 8. Bombycillina, or swallow chatterers; 4. Ampelinc, or true chatterers; 5. Piprince, or manakiu chatterers. The three first are aberrant, but the species are so few that we have no inclication of a circular union : the two latter are the typical groups.

(83.) In the first division we have only two genera, Leiothrix and Pteruthius, both belonging to Tropical India, and each represcnted by a single species. 'The bills of these birds are short and morlcrately strong, with the lip notched; that of Pteruthius is stroug and abruptly bent, giving it very much the character of the 
genus Pachycephalus. Both these genera differ from all others in the family by having short rounded wings and large feet, the tocs of which are nore or less unitcd at their base. These latter characters are very essential, becausc by them the birds in question are proved to have no connection with the shrikes, to which family one of them has been hastily referred, on account of its abruptly hooked bill: this latter structure, incleed, is so striking that we should have had soine doubts whether Pteruthius really belonged to the chatterers, if one character alonc is to be considered; but then the very same reason might be urged against the admission of Vireo, Pachycephala, and even Pardulotus : nay, Crytura itself must follow; for each and all of these have the tip of the bill as mucl hooked, and as strongly notched, as Pteruthius. In regard to Leiothrix, its old name of Parus furcatus fortunately points out that this curious bird has a nearer relation to Parus than to any other genus; and it must be remembered that in our exposition of the last family, the Pariunce is precisely that group which forms the passage from the warblers to the chatterers. Thename of Leiothrix will express the soft and silky texture of its plumage: the bill is not unlike that of Vireo and Pachycephalu, the under mandiblc being nearly as thick as the upper, - a form which we have been alrcaly prepared for by the Trichles velatu; the most aberrant species yet discovered anoug the titmicc, and consequently that which makes the nearest approach to the chatterer fanily. Like that bird also, Iseiothrix has very long legs, but its wings, from being rounded, resemble those of Fireo and Pachyccphalt. It peculiar distinction, however, lies in a short but deeply forked tail, the ends of which diverge outwards in such a manner that we are immediately reminded of the drongo shrikes. These two genera are the only birds we can yet place in this subfamily; but we have casually inspected onc or two others, also inhabitants of India, which quite satisfies us that future discoveries will bring to light other links of the series between the Piprine and the next group. 
(84.) In the second subfamily we placed three wellmarked genera, - Vireo, Laniisoma, and Pachycephala, $\mathrm{Sw}$. The genus Vireo is composed of little green coloured warbler-like birds, somewhat resembling flycatchers, but readily distinguished from that family by their strong legs, and their cylindrical bills, the base of which is not dilated : while the abrupt hook of the upper and the thickness of the lower resemble the structure seen in the genus Myothera. There are, nevertheless, two distinct sections of these birils, which may possibly constitute subgenera: in one, represented by Vireo olivacerus, the red-eyed flycatcher of Wilson, the wings are pointed ; in the other, to which belongs the white-eyed warbler of the same author, they are rounded: these are connected by the $V$. ftavifrons, which has the bill of this genus and the wings of the next: thus all doubt is removed on the affinity between Virco and Puchycephala, two genera, however, which in other systems stand in different families. The thick-headed chatterers (Pachycephala $\mathrm{S}$ w.), are entirely confined to New Holland; they resemble small thrushes more than any other birds, and as such have been. described. Lewin informs us that several species have a loud, slirill, and pleasant note, which they sing about daybreak, when perched on the upper branches of high forest trees; and it is rather curious that similar situations and times are chosen by the typical chatterers of South America for uttering their uncouth cries. Of the economy of this group, in other respects, we unfortunately know nothing: they may live partially upon fruits; but the long and weak bristles surrounding the bill clearly show that insects constitute a part of their nourishment. The third type which enters into this division, and which seems intermeliate between the two last, is represented by a vcry rare Brazilian bird as big as a small thrush. It has the elongated and abruptly hooked bill of Vireo, with the large puffy head and rounded wings of some of the Australian Pachycephala. Differing, however, from the latter in scveral points of structure, as well as in geographic distribution, 
we felt it necessary to give it the subgeneric name of Laniisoma.**

(85.) The third aberrant division is indicated by the European chatterer, the singular forkcd-tailed genus $P$ hiba-

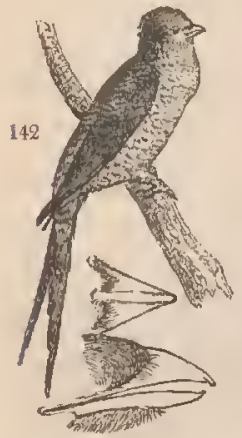
luru(fig.142.) (P.favirostris Vieil. $\dagger$ ) and the Procnias ventralis III. + , or green swallow of Brazil. All these birds, particularly the first, are remarkable for the great length of their wings, the first quill of which is nearly the longest. This structure invariably indicates great powers of flight; and as we find a different form of wing in the typical genera, so we slctach these birds from all others of the family, and consider them as the fissirostral type: the fect, although strong, are particularly short, while the length of the anterior toes, in comparison with the hinder ones, offers a decided analogy to the true swallows. This resemblance, indeed, is so strong as to have formerly induced M. Temminck to place one species (Procnias centralis Ill.) in that very group which it only represents. All these charactcrs are more especially seen in the European clattcrer, which thus becomes the represcntative of the group.

(86.) We now come to the two typical subfamilies, upon the first of which, the $\Lambda$ mpersw.s, we can speak with much more certainty, since the forms and species are by 110 means few. Some of the most extraordinary bircls in creation belong to this group; while others, by being clothed in the ricliest hues of blue and red, nearly rival the humming-birds. The former are generally the size of a large thrush, and their singular appendages, if not ormamental, are certainly grotesque. One has the neck furmished with a number of long, slender,

\footnotetext{
* Northern Zoology, vol, ii. p. 492.

+ Zool. Illustrations, i. pl. 31 .

$\ddagger$ Ibid. i. pl. 21 .
} 
naked wattles; while, from the forehead of a second, rises a fleshy carunclc, which, when elevated, reminds us of the horn of a unicorn, but which is probably carried like that of the turkey; a thirl is perfectly white, with the face and throat barc of feathers, and of a beautiful green colour. Could we but know the habits and economy of these singular birds, which, had they not been seen, might be thonght fabulous, what an interesting pagc of nature's volume would be unfolded! Yet, at present, we only know that they live in the deepest and most secludel forcsts of Tropical America, where they subsist upon an infinite variety of fruits unknown to Europeans. They are much oftener hearcl than seen, since their notes are particularly loud, and are uttered morning and evening from the deepest recesses of the forcsts: we have sometimes canght a distant view of them, perched upon the topmost branches of the loftiest trees. All the species above alluded to are comprised in the genus Casmorinynchus of $M$. Temminck, while the beautiful gcnus Calyptomina of India forms the passage from this genus to the swallow chatterers just deseribed. We quit Casmorhynchus for the genus Ampelis, or the true chatterers, called by the French Cotingu, and constituting a group

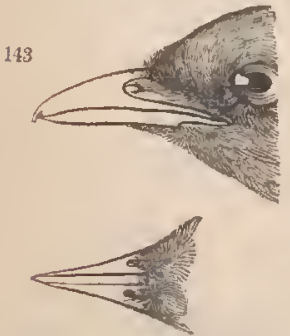
of surpassing beauty: they arc rather sinaller in stature, and, but for their shorter and broader bills, might be taken for thrushes. There is a peculiar soft, silky, and glossy texturc on the feathers, which increases the splenclour of the changeable blue, purple, and dark red, which generally spreads entirely over their plumage. They differ from the last also, which are plain coloured birds, in the head and ncek being always clothed with feathers in the usual manner. Le Vaillant, in one of his costly ornithological works", has figured nearly

* Hist. Nat. d'une Partie d'Oiseaux de L'A mérique et des Indes. 
all the species. In Casmorhynchus and in Ampelis there are no cresterl birds ; but this omament forms the principal distinction of the genus Rupicolu, or rock manakin of Cayenne. 'The familiar mame of cock of the rock, long bestowed on this bird, is very characteristic, since it unquestionably represents the rasorial type of the true chattercrs: by this we are led to the Ampelis carnifex of Linnxus, forming our genus Phonicercus; a remarkable form, having the general habit and sizc of this division, and the feet of the true manakius, to which now we proceed.

(87.) The Prprive constitute the subtypical group of this family: they are called manakins, from their dimi. nutive size, which is seldom larger than that of a tomtit. Here again we find the richest tints of yellow, orange, crimson, and blue, rclieving the olive green or deep black plumage of thesc elegant little birds. Like the preceding, they are strictly American, and chiefly occur in the deep virgin forests of the tropics, but they are much more social than the Cotingas. They live in little bands, are continually in motion, and feed almost entircly on the large soft berries of the different spccies of Melastoma. 'The nest of one species ( $P$. pareola) is often built in the fork of a shrub, in such an exposed manner, that the female can look all round and watch the approach of danger: wc fouml one in such a situation in the forest of l'itanga, a single leaf of a large pepperplant (Piper) forming a kind of unbrella shade over the female, which was sitting, and did not rise from her nest as we passed onward. The manakins are easily known by thicir wcak and very slender feet, of which the two outer toes are considerably united. By that singular little bird Calyptura cristata * the genus Pipra is united to that of Pardalotus Vieil, or the spotted manakins of New Holland. Of a size equally diminutive, these are nevertheless distinctly separated from the last by their stronger bill and more pointed wings; while the feet are stronger, and more perfectly formed,

\footnotetext{
* Birds of Brazil, i. pl. 24.
} 
all the toes being divided. Lewin, in his Birds of New South Wales, when describing one species, remarks, that it frequents high forest trees, constantly singing a short but pleasing song in passing from tree to tree. This genus, in all probability, represents that of Diceum among the honeysuckers, and Euphonia among the tanagers. 'The subgenus Metopia* seems necessary to connect Phoniccrcus with Pipra; and there are one or two birds evidently bclonging to this division not yet described, which, by their stronger bill, evince a tend. ency towards uniting with Lciothrix.

(88.) On a general review of the affinities of this intricate group, the systematic ornithologist will observe that there is more than one considcrable hiatus in the series, and that the situation of several of the subgenera is extremely cloubtful. Upon this we shall offer a few words. It has been imagined by some writers, that the fewer species or genera there may be in a fanily or group, the more easily may they be arranged: 110w, this may be very true, if an arbitrary or artificial system is the object proposer ; but when that of nature is to be studied, the very reverse of this opinion must naturally and obviously be true. In respect to the Ampelida, there are fewer forms and species than in any other family of the Dentirostres; and, therefore, in distributing the aberrant genera into three divisions, it is more for the sake of perspicuity than from any confidence we have that these primary divisions are natural. On the two typical groups there can be no doubt, nor have we much on that which contains Bom. bycillu; but the accuracy of the two others may be reasonably questioned, or at least they should be looked upon with doubt. There are certain characters in the genus Pachyceplata, which leads us to suspect that it is the scansorial type of the whole family, and that it consequently enters into the same division with Leiothrix; this woukd also comprehend Vireo, and thus these two genera, the one closely rescmbling Parus, * Metopia galeata; Birds of Brazil, i. pl. 23. 
and the other Sylvia, would comc into that group of the Ampelide which forms a passage to the Sylviadce. If this suspicion is well founded, the grallatorial or tenuirostral type is still undiscovered. Hitherto we are unacquainted with any bird of this family which feets upon the ground, and which might therefore be supposed to supply this deficiency; but the crested thrush of Lewin *, judging from the figure, appears betwcen a lark and a Pachycephala, and may, therefore, possibly be the type in question. It is describer as inhabiting rocks and barren "scrubby" places, having a jerk in its walking motion, at the same timc erecting its crest like the cockatoo: but as no specimen of this bird has yet passed under our obscrvation, our suspicions are consequently founded on mere conjecture.

\section{CHAP. VII.}

THE DFXTIKOSTRES CONCLUDED. - ON THE MUSCICAPIDE, OR FLY-CATCHERS.

(89.) Tire most insectivorous family of the Dentirostres is composel of the Muscicapide, or flycatchers; a group hardly less numerous than that of the warblers, and composed, like them, almost entirely of small birds : both families are inscctivorous, that is, halbitual devourers of insects; but very many of thc warblers (even in the more typical genera) fecd also upon fruits, of which the robin, the blackcap, and the whitethroat are notable examples. The flycatchers, lowever, properly so called, secm to be strictly and exclusively insectivorous, or, at least, it has not yet been ascertained that any of the specics composing tlic typical group Muscicupina ever partake of fruits. This peculiarity of diet, independent of many others, separates them from the warblers on

$$
\text { *B. of N. H, pl. } 9 .
$$


one side, and from the Ampelida, or chatterers, on the other; while another is to be found in the mode or inanner of their feeding. The warblers tly about, hunting down their prey, searching among trees, and roaming from place to place after their favourite food ; lence they become ambulating flycatchers; and their feet are consequently large and strong in comparison to the size of thcir bodies. We need only look to the gold-crested and wood warblers as exemplifications of this remark, even among those species which frequent trees; but in such, as in the stoneehats, Suxicoline, and Motacilline, as habitually walk, the feet are inuch stronger and the shanks more lengthencd. Now, the very reverse of this strueture is the typical distinetion of the flycatchers; their legs are remarkably small and wenk, - more so, per.haps, than those of any clentirostral birls, - showing at once that their feet are but little userl; and such we find to be the case. The flycatchers constitute the fissirostral type of form annong the leading divisions of the Dentirastres, and they consequently exhibit all the chief indications" of that PriMARY TYPF of nature, as it is exhibited in the feathered creation. These, as the intelligent ornithologist already knows, are manifested in a large and rather wide mouth and bill ; short, feeble, and often imperfect feet; great powers of flight, and often a considerable length of wing : the developement of this latter structure is not always apparent, but it is the peculiar power of their Alight upon which they chiefly depend for procuring subsistence. They are mostly sedentary, and only dart upon such inseets as eome within a sudden swoop, without attempting to pursue their game further, if unsuccessful in the first instance: they return, in fact, to the spot they left, or to another very near, and there await patiently until another inseet passes within the proper distance. This habit of feeding at onee explains the reason of the feet being so small and weak, by showing that they are merely used to support the body ; or, at least, that they are not employed

* Classification of Animals, p. 249. 
in constant exercise or exertion, as in the generality of other birds. Other characters accompany these, no less indicative of birds which feed exclusively upon the wing : the bill is always considerably lepressed or flattencd, particularly at its base; and the sides of the mouth are defended with stiff bristles, to confine the struggles of their prey.

(90.) The geographic range of this family, taken collectively, extends to the temperate and tropical latitudes of the Old and the New World; although, strictly speaking, there are probably no genuine flycatchers in North America, where their station would seen to be filled by the little tyrants (Tyrannula) and the flycatching warblers (Sylvicnline), both which groups are unknown in Africa and India, - the two countries most prolific in the typical species of Muscicapa. Having already unade the natural arrangement of this intricate and interesting family the subject of a separate work which our space in this will not enable us again to go over, the reader must be satisfied with a rapid survey only of the primary divisions. The contents of the entire family, together with the singular and beautiful analogies presented by the latter groups, even in their most ininute details, will be found fully illustrated in the work alluded to.

(91.) The primary divisions appear to be represented by the following genera: - Euryluimus, MIuscicnpa, Fluvicolu, Psaris, and Querula : these constitute, according to our present vicws, the types of so many subfamilies, very unequal, indeed, in their contents, yet blending sufficiently into each other to point out their circular succession. The two first are clearly the typical and the subtypical groups; the three next are aberrant.

(92.) The Eurylaimince, or broadbills, are the most remarkable birls of the whole family: the species are very few, and their geographic limits seem to be restricted

* The Natural History and Arrangement of the Muscicapida, or Flycatchers. 


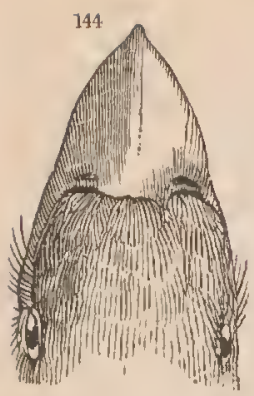

to the hottest parts of India, where they inhabit the forests. In size they exced all others, save the genus Querula, in this family, being about the size of starlings; while the enormous breadth of their bills, and the peculiar brightness of their colouring, renders it impossible for the student to mistake them for any other genus. The bill (fig. 14.4.) is not only excessively broad, but the margins of the base are so dilated, that they often project over those of the lower mandible, while its substance seems inuch more solid than in the ordinary flycatchers. Although very few species have hitherto been discovered, it is quite clear that the five leading types have come to light, although only one example of the genera Serilophus, Psurisomu, and Platystoma are yet known. It inay here be observed that, notwithstanding the great width of the bill in all these birds, it is nevertheless much more convex above, and in some instances is even morc raised on the culmen, thall any of the others: the feet, also, and the whole structure of the body, arc more robust. Hence, al though the width of the mouth, and the great size of the head, would indicate this to be the pre-eminent typical group, yet all the other eharacters would place it as the typical. Serilophus is evidently the rasorial or crested type; and it departs consilerably from the others, by the only species yet known being very fond of fruits : this is in conformity with the strong and remarkable analogy it shows, even in its outward appearance, to the wax-winged chatterers (Bombycillic).

(93.) The great subfamily of Muscicapinse is that which contains the ordinary flycatchers. These birds, in comparison to the last, are much smaller in size, and weaker in the whole of their conformation: none are so large as a sparrow; and the generality do not

VOL. II. 
exceed the dimension of that species so common in England - the Muscicapa grisole. The bill, although it is rarely so broad as in the last group, is much more flattened; and the bristles at the gape are more developed. Their whole structure, also, is more slight and delicate; but their colouring, although sometimes elegant, is almost devoid of vivid tints. The different form and length of the bill and feet furnisl the characters by which the genera and subgenera are distinguished; while the species, which are excecdingly numerous, with the exception of the genus Todus, are only found in the Old World. The typical genera are Todus and Muscicapa; the aberrant are Megalophus, Monacha, and Rhipidura: the two first are so uumerous in species as to contain subgenera; and they will, therefore, require a more detailed notice than we can give to the others.

(94.) I'lic recent re-discovery of the genus $M$ egalophus, - which, although known to Buffon, remained lost to modern ornithologists until very lately, - together with that of Serilophus, nearly at the same time, has established that inmediate reunion between the last and the present subfamilies which at once demonstrates their close affinity. This genus, at present, is represented only by a single bird, the Todus regius of the old authors, which seems to inhabit a very limited district in Tropical America. It is, in many respects, a most extraordinary type, - possessing, like Prionops among the Ianiado, a complete rasorial crest, with the short and imperfect feet of the fissirostral structure. With such a combination of characters, it is almost difficult to say to which type it truly belongs: but such instances are by no meaus uncoinmon; and, as Rhipidura, at the opposite side of the circle, has the longest feet and the largest tail, we may consider the latter as the rasorial, and Megalophus as the fissirostral, genus of this circle. The truth, however, seems to be, that in very small groups like the present, the primary types of nature do not show all their own characters, but impart some one of them, as it were, to its neighbour. 
This blending of forms, distinct in themselves, in small circles of affinity, is not at all peculiar to birds, but seems to be a universal law of nature. Be this, however, as it may, certain it is that no genus of the Muscicapino makes so near an approach to Eurylaimus as this, more especially since the discovery in India of Serilophus, as already mentioned.

(95.) The next aberrant gemus is Monacha. Its characters were pointed out long before it received this name, which is nevertheless antecedent to that of Drymophila, subsequently proposed for it without any assignable reason; and, in the face of the fact of this very name, Drymophilit, having been employed by us long before, to designate a totally different group. All the birds of this genus are restricted to Australia and its neighbouring isles : as they are the most aberrant of all the flycatchers, so are they the most dissimilar from the typical examples: the bill, in fact, is strong, and is very little depressed, while the culmen is arched and elevated. All the other characters of its congeners, however, arc preserved in the wings and feet, so that we can have no doubt of its true station, more particularly when we call to mind the genus $P$ saris, hereafter noticed, which this

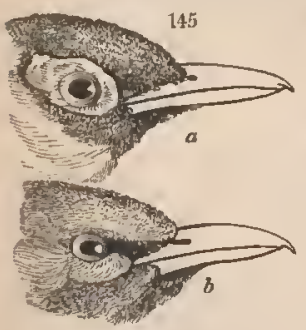
genus represents in its own circle. It is somewhat singular that the original describers * of our Monacha telascophthalmus (fig. $14.5 a$.) and Chrysomela (b) should have made these birds in to anew genus, when it is quite obvious they are typical cxamples of the present group: they are certainly two of the most beautiful species yet discoverel ; the first showing the analogy of Monacha to Ceblepyris, Psaris, and Charadrius, and the second indicating the same relation of the group to Oriolus and the paradise oriole, each and all of which as being tenuirostral types, become mutual representatives

* Lesson et Garnot, Zool. de la Coquille, pl. 18, f. I, 2 . 
of each other, not merely in theory, but actually so when the circles of affiuity, wherein these birds are placed, come to be conpared with cach other.

(96.) Rhipidura is the thirl of the aberrant divisions: like the last, it seems peculiar to the Australian range; and is distinguished at once from all the precerling, hy its very long legs and its large fan-shaped tail. The typical species, at least, are thus distinguished; hut some doubt hangs over the limits of the group, chiefly from our ignorance of the manners of several birds, which arc supposed to come within its range: in our systematic arrangement we have specified the typical characters, and must leave other points for the present undetermined.

(97.) The genus Muscieapn, the most numerous assemblagc in the whole family, obviously succeeds to the fantailed flycatchers. In our introductory remarks, we have inore especially advcrted to these birds, and this saves us the necessity of recapitulating their typical characters. 'The whole are natives of the Old World; and they present so much diversity in the different forms of their wings, bill, and feet, that we have ventured to designate the five leading forms : these will be found in our systematic arrangement, under the names of Muscipeta, Myingra, Muscicapa, Hyliota, and Seicercus. The most striking individuals belong to the first of thcse sulygcnera: they are distinguished by their long penlant tails, and beautifully varied plumage ; while nearly all the spccies are confined to the tropics of Africa and India. MIÿngru is a more homely coloured group, inhabiting the same countries, but extending also to Australia: to this succerls the Furopean form, conspicuous by its lengthened wings. Hyliota, as having the longest bill in this genus, seems to be the tenuirostral type; while Seicercus, from its fan-shaped tail, crested head, and lengtliened feet, equally indicates the rasorial form. The whole are distingnished from the todies by the shortness of "their bill and legs, and the comparative elongation of their wings. 
(98.) The restricted genus Todus is at once discriminated from the last by having directly opposite characters. With the exception of one of its subgenera, Platystera, the whole are natives of 'Tropical America, where, in conjunction with the tyrant flycatchers, or rather

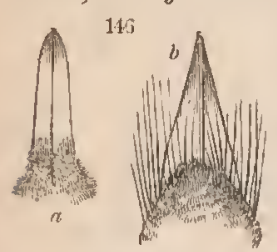

shrikes, they represent the true Muscicapidae of the Old World. The tollies (fig. 146. a) have the bill equally depressed with that of the true Hycatchers $(b)$, but it is considerably longer, and, instead of being triangular, it is boat-shaped: the wings are so short and rounded as to loe obviously incapalble of any other than the inost feeble flight; while the legs, which, in the Muscicaper, are so very slsort, arc here much lengthened. Although the toes are equally small, and imperfectly developecl, this great difference of organisation in the organs of locomotion carries with it a corresponding diversity of habits. The todies, so much restricted in their powers of thight, depend more upon their legs than their wings. Such of the Brazilian species as we occasionally met with, appear to hop about among the slcnder branches of trees, something in the manner of titmice, hanging from the twigs, and occasionally making a short flitting with their wings, for about two or thrce feet, to capture an insect that attempted to escape; but how far this habit is shared by the majority of the genus future observatious must determine.

(99.) The subgencra, or types of form, intimately correspond to those in the last genus: this assertion we shall elsewhere cndeavour to establish, by the most complete analysis that has ever been bestowed upon an ornithological group. We have only space, however, in this work, to enumerate their names and some few of their peculiarities. In the first, which is Lepturus, the bill still retains much of that triangular shape characteristic of a flycatcher; but the legs are remarkably long and the wings uncommonly sliort. This type is connected to 
Todus, the pre-eminent or typical subgenus, by a beautiful gradation of forms, which leaves not a single gap in the serics. In Todus, the bill exhibits that lengtl and boat-shaped appearance before alluded to (fig. 146. $a$ ), together with a remarkably short tail, and delicate although lengthened legs. These latter cliaracters are continued to Platyrynchus ( fig. 147.), but the bill has now become

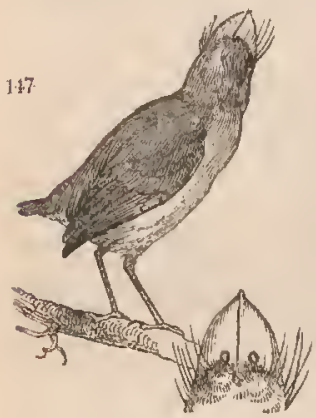
short, and so broad as to present a miniature resemblance to that of Eurylaimus : thelegsarelong, but so remarkably dlelicate as to show they are not at all adapted for walking. In the next type, however, represented by the subgenus Conopophaga, the legs are not only long, but unusually stout, thus indicating that they are much used, and probably on the ground. 'The bill is still short, but by no means so broad or so weak as in the last, while the base is destitute of bristles. Finally comes Platystera, the most aberrant group of the todies, and altogether peculiar to $A$ frica.
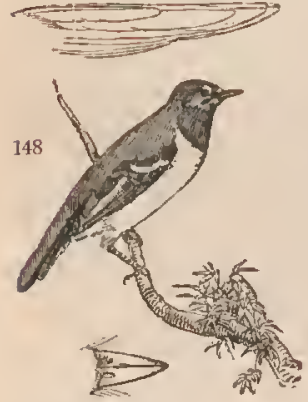
These birds are known at once from all the American forms, by being larger, more robust in their general shape, and having certain modifications in the form of their bill, wings, and tail, altogether peculiar: a glance at the most typical species, $P$. lobata (fig. 148.), at once reminds the ornithologist of Monacha, which, together with Psaris and Hyliota, these birds appear to represent in their own circle. 'The union of Platystera to Lepturus is effected by the Migniotte of Le Vaillant*; aud its 
connection to Conopophaga is equally demonstrated by the Platystera syndactyla Sw., an African bird in the British Museum, having merely the rudiments of a tail, with very sliort, unequal, and syndactylc lateral toes. The circle of Todus is thus completc; and we shall now see, by placing them togetlıer, how it agrees with the genus Muscicape :-

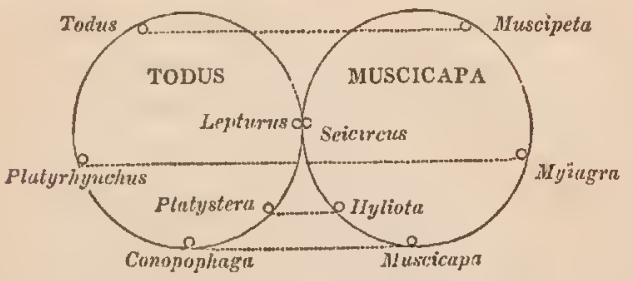

(100.) Tlie longest bills among the Muscicapre are found in the typical group; and so, also, are the longest among the todies. Several of the flycatchers in the subgenus Myiagra are to this day described as species of Platyrynchus by molern authors, notwithstanding their only resemblance consists in the unusual brcadth and shortness of their bills. Conopoplaga and Muscicapa have the bill small, and but slightly dilated, although they arc both remarkable for their length of leg. Platystera and Iyliota agree in having the ridge of their bills, or the culmen, elevatcd, and in the outcr half being often compresscd: their wholc appearance, also, is more like to each other than to their own types. Lepturus and Seicircus differ from all their congeners, by their elongated fan-shaped tails. If, as we strongly suspect, Rhipidura is not a gemus, but a subgenus, of Muscicapa (in which case it would take the place of Seicircus in the above circle), the analogy would be equally perfect, bccause Lepturus, no less than Rhipidura, is unquestionably a rasorial type. To place this beyond all doubt, it is only necessary to compare the subgenera of

$$
\text { G } 4
$$


Todus with the orders of birds, and the tribes of the perchers, as in the following table:-

$\begin{array}{cccc}\begin{array}{c}\text { Subgenera of } \\ \text { Todus. }\end{array} & \begin{array}{c}\text { Genus Tonus. } \\ \text { Analogies. }\end{array} & \begin{array}{c}\text { Tribes of } \\ \text { Perchers. }\end{array} & \begin{array}{c}\text { Orders of } \\ \text { Birds. }\end{array}\end{array}$

Todus.

Bill lengthened, conie,
slightly notched. Coninostres. Irsessores.

Platyryncius. $\left\{\begin{array}{l}\text { Bill short; lip abruptly } \\ \text { hooked; notch or tooth } \\ \text { very distinct, }\end{array}\right\}$ DeNmRostaes. ,Raprones

Conopophaga. $\left\{\begin{array}{l}\text { Feet syndactyle; head } \\ \text { large. }\end{array}\right\}$ Fissirostres Natatores.

Platystcra. Bill slender. Tenuirostres. Grallatores.

Iepturus. $\left.\quad \begin{array}{c}\text { Feet large; toes eleft; } \\ \text { wings short; tail long. }\end{array}\right\}$ Scansores. Rasones.

(101.) It is quite unnecessary to add any thing in further proof of the correctness — we may even add the beauty - of this perfect illustration of the theory of representation ; and yet, the more it is looked into, the morc perfect do the analogies come out. The form of the bill, for instance, in Todus, when vieured vertically, is precisely that of a conirostral bird; and this observation equally applies to the typical genus Muscipeta. Platyrynchus, like all dentirostral types, is that where the bill is always shorter than in the conirostral, and where the tip is most abruptly hooked or bent down. Conopnphaga, from its large legs, might, on a cursory examination, be mistaken for a rasorial type; but its toes are syndactyle, while its large head and very short tuil clearly demonstrate it is, in reality, a representation of the Fissirostres aud the Nutatores. Platystera and Hyliota are the furthest removed from their own types, and their analogies, as a necessary consequence, are more remote than any of the others; but Lepturus and Seicircus unite, and therefore their analogies blend into affinities: these two subgenera, in fact, are those only which have the feet quite perfect, - that is to say, the tarsus is lengthenef, and the toes fully cleft. This structure, and the pointed form of their tail feathers, is in exact accordance with what every ornithologist knows to be the most conspicuous characters of the rasorial order, as the philosophic inquirer will find more perfectly and 
fully illustrated in the volume before alluded to. We must now pass on to the three aberrant divisions of this family, namely, the Fluvicolince, the Psariance, and the Queruline.

(109.) The Fuvvicolins, or waterchats, with the exception of one genus (whose situation is still somewhat doubtful), are entirely restricted to the warm latitudes of America, where they seem to represent the stonechats and the wagtails of the Old World. They are strictly ambulating flycatchers, and constitute the rasorial division of this family. The legs are consequently very long, and formed especially for walking; the toes are also long, quite divided to their base, and furnisled with long and slightly curved claws. This structure enables these birds to run with great celerity; and they are generally seen on the sides of streams and rivers, feeding upon flying insects which resort to such situations; for they never hunt among trees, and rarely perch: such, at least, arc the manners of the typical species ; but there are, of course, various nodifications of liabit corresponding to those, which will now be glancel at, in their structure. 'l'he first genus with which we begin the series, is that of Seisura*, differing only from Rhipedure by its more lengthened bill and feet. Both these divisions, as well as that of scicircus, have broad fan-shaped tails, which plainly indicates the type to which they belong, although the rank they respectively hold cannot, in our present state of knowledge, be clearly ascertained. Leaving this group, we reach that of Fluvicola, by means of certain black and glossy birds of Brazil, some of which have distinct crests: these latter conduct us to the typical Fluvicole, having the legs unusually long, the bill depressed, the tail lengthened, and the plumage

* I feel by no means satisfied that Seisurn is naturally separated from Rhipidura, although, for the present, I have adopted the group as proposed by MM. Vigors and Horsficld. I have, nevertheless, some suspicion, that all the genera of the Fluvieslina may prove to be natives of Tropical America, and that Sesura is only composed of those aberrant specles of Thipidura which pass into the Fluvicoline. 
differently varied with white and black. One of the most characteristic of these singular birds is the Fluvicola cursoria , of the size of a lark; but some are nearly equal to a small thrush. Perspicilla, so called from the naked fleshy lobe which surrounds the eyes like spectacles, is the next genus: this is succeeded by Alectura, one of the most distinct and well defined groups in the whole circle of ornithologyt: the remarkable developement of the tail feathers in this group only finds a parallel in the genus Vidua among the finches, and that of Gallus on the rasorial circle. Besides these genera, there are several black and white coloured birds

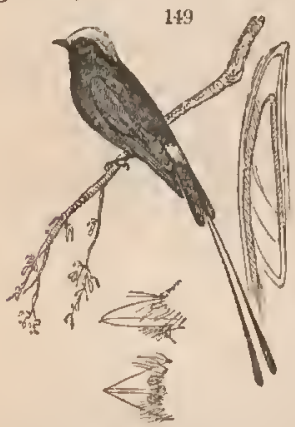
liaving a general resemblance to the foregoing, which would seem to euter among the waterchats; yet, as we have not sufficiently analysed the group, we must leave this point undetermined : among these are the white-headed tody of the old writers, which is either a $T y$ rannula or an aberrant Fluvicola, as well as the Muscicapa leucocilla of Hahn (fig. 149.), which, in outward appearance, so much resembles a manakin, that it may possibly prove a representative of that fanily in the present circle.

(103.) In the subfamily of P'sarians, to which Alectura immediately leads, there are but three ascertained genera. These birds, like their representatives, Monacha and Psarisoma, depart considerably from the types of this family : the bill is less depressed than any other of the flycatchers, and its structure is altogether stronger

* Zool. IIl, if. pl. 46.

+ Why M. Vicillot, who first characterised the genus, subscquently abandoned it by uniting it to the overloaded group of Muscicapa, bas never been explained. This, however, in the present state of sciencc, is of no conscquence; since it does not, according to our analysis, belong even to the same subfamily. 
and thicker: they are all natives of Tropical America, and are generally found only in thick forests. Gubernetes is the gcnus by which they appcar connceted to the waterchats, through the medium of Alectura. One species only is yet known, the Gubernetes forficatus, remarkable for its long forked tail: to this succeds Psaris, where wc find nearly all the spccies coloured alike; that is, they are more or less of a grey or pearl white, witl black head, wings, and tail: they remind us immcdiately of the gulls, and this analogy is one of the most beautiful, when worked out, in the whole fafamily. The smaller birds of the genus Pachyrynchus immediately follow.s Two or three already prepare uc for the next division, by the great depression of their bills, and the singularly formed red feathers on the throat.

(104.) The singular genus Querula is the type of the Qucrulima, or the last subfamily of the flycatchers. By some of the Linnean writers this remarkable bird is classed as a Muscicapa; while by others, even among the moderns, it is considered an Ampelis. Now, both of these opinions may be reconciled, by viewing it as it stands in our arrangement - the connecting link between these families. All the flycatchers we have hitherto noticed, so far as we yet kuow, feed entirely upon insects; but we have unquestionable testimoly* that this species live also upou fruits, thus uniting in itself the characteristic of the two familics which it connects. In the bill there is much of the form and strength of Psaris, but it is widc and more depressed; while the stiff bristles at the rictus betrays its insccivorous habit: the fect are rcmarkably short for the size of the bird, and are calculated only, like those of the Ampelida, for perching. All these characters not only point out this genus as of the fissirostral type, but perfect the union of the families of Muscicapida and Ampelida. 


\section{CHAP. VIII.}

ON THE CONILOSTRES, OR CONIC-BILLED TRIBE.

(105.) The Conirostral tribe is the most highly organised of all those which form the grand division, or order, of Perchers ; of which, in consequence, it is pre-eminently typical. 'The prominent distinctions of these birds, and the characters by which they are separated from the tribe we have just quitted, have more than once been touched upon." The general reader will form no inaccurate idea of the contents of this circle, by looking to a crow (fig. 150.a), a starling (b), a sparrow (c), a plantaineater $(d)$, and a hornbill $(e)$; and associating in his mind all those birls whose conic and slightly notched bills ap-

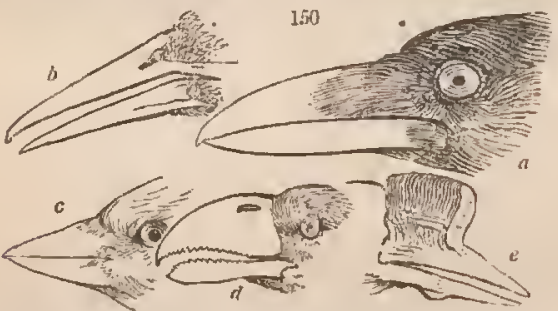

proximate more or less to one or other of these forms ; in none of which do we observe that degree of curvature and dentation of the upper mandible, so characteristic of dentirostral birds. To define them, however, with scientific accuracy and exclusiveness, is much more difficult ; seeing that, as in all large groups, they possess no one character which is not found among those birds which are connected with, but do not euter into, the circle of the Conirostres. That distinction, however, which appears most general, is the strong conic-shaped form 
of the bill, which is scarcely ever so decidedly notched as that of the Dentirostres, witl which alone the present group can be confounded. In all the aberrant tribes of perchers, - that is, in the Fissirostres, Tenuirostres, and Scansores, the feet are very short, generally weak, and always imperfect, - they exhibit a structure calculated for onc purpose alone, as the woodpeckers; or at most two, as in the parrots. But, in the present tribe, the fcet are developed in their just proportions, and are suitable botl for percling, walking, and climbing horizontally among trees; the toes, in almostevery instance, being placed thrce forwards and one backwards.

(106.) The primary divisions of this order will now be explainesl, but the mode by which the thrce aberrant families are united into a circle is not yet knowir. These aberrant groups we sliall denominate the Bucerida, or hornbills; the Musophagida, or plantain-eaters; and the Fringillide, or finches. The two typical groups have been correctly named (from thc crow and the starling) the Corvida and the Sturnide. The contents of each of these families will now be explained.

(107.) The Bucerida, or hornbills, are well distinguished at first sight, by the enormous size of tlieir bills, which are generally swollen or enlarged at the base, as the name implics, into protuberances resembling horns or nobs. In some species, however, the bill is without these appendages, so that they bear the nearest affinity to the toucans - belonging to the scansorial tribe, which is joincd to the conirostral. We have no bird, indeed, which actually unites the two fanilies in so perfect a manner as that by which the toucans are blended with the Fissirostres through Prionites; yet this latter group fulfils the double purpose of pointing out both affinities: we sec in the little power possessed by the toucans of climbing, that nature is about to quit the scansorial structure. Now, we should expect that a bird which might conduct us from the toucans to the hornbills would be of a large size, and that it would present us with some of the gay colours peculiar to the toucans, both in its bill and plumage; 


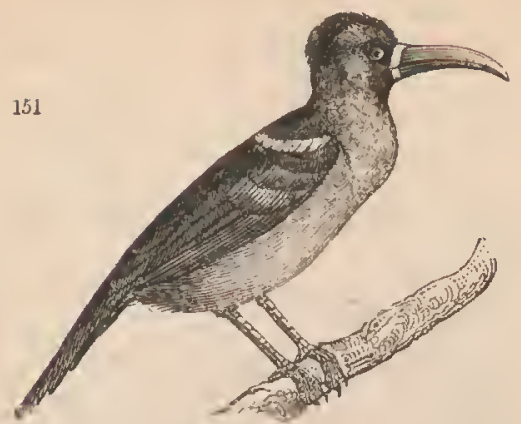

but that its feet should no longer exhibit the scansorial structure. Now, there is good reason to believe such a bird is in cxistence, although at present only known to modern writers, by a drawing executed in India, in the collection of Mr. Smith. Both Dr. Latbam and Dr. Shaw, describe this bird under the name of the crimson hornbill; and we consider that the figure (fig. 151.) published by the latter carries internal evideuce of its authenticity. In short, we see in this bird the crimson colour, the long tail, and the dorsal collar so prevalent in the genus Pteroglossus, joined to a miniature toucan's bill, with a distinct band at the base, like the Ramphastos tucanus, yet with the feet of a hornbill. That this bird, and probably other annectant species, will hereafter be discovered in the vast and still unexplored regions of Central Asia, we have no occasion to doubt.

(108.) The hornbills are a sinall family, of which, perhaps, the typical form is now only known; they are conscquently as much isolated as the toucans and the parrots. 'They are gregarious, noisy birrls, generally of a very large size, and are restricted to the Old World. They are omnivorous, feeding both on auimals and vegetables: somc, however, seem ouly to partake of the latter fool; while others, upon the authority of Le Vaillant, feed upon carrion. Their bills are enormously large; and generally furnished with an appendage or excrescence on their top, the use of which is unknown; nor has the 
internal structure of this member been fully ascertained. Lastly, the feet are generally so very short, as to appear calculated only for pcrching. United to the scansorial birds by means of the toucans, they would seem to represent the Rasores, but the structure of their feet, more imperfect than any of the familes in this order, forbids the supposition. 'This opinion we had long entertained from theory, but it has recently been confirmed by a singular fact in their economy, communicated by an officer long resident in India. It seems that all the species of Buccros he has met witl in a live state, are constantly in the habit of throwing their food up in the air, and catching it before it is swallowed! It is impossible to inaginc a more beautiful insipient developement of the fissirostral economy than is manifested by this propensity - a propensity which, divested of its analogical relations, would be perfectly incomprehensible, seeing that the birds are not obliged (like swallows, and all the true Fissirostres) to catch their food in the air in the first instance.

(109.) The Convins, or crows, appear to be that family nearest allied to the last, althougl the intervening forms are few. The genus Frigilus, in fact, is the only representative we at present know of that subfamily which intervenes between the Buceride and the Corvina. The whole farnily, in short, has never yet been analysed; so that the leading divisions alone can yet be marle out or stated with any degree of certainty. The little value that can be attached to speculations on the rank of the present gencra, founded upon mere synthesis, will best appear by looking to those artificial arrangements that place the short-legged rollers close to the long-legged and powerfully constructed grakle (Grucula religiosa), - two genera, moreover, which analysis has convinced us do not belong to this family. Nothing, in short, is more easy than to dividc a group like this into three, five, seven, or any other given number; but the divisions must always be considered as temporary, until confirmed by analysis. We have not yet carried our investigations so far as to lay before the reader an 
arrangcment of all the genera of this family; nor will our space admit of an attempt to demonstrate those groups in it which we have already worked out. We shall, therefore, mercly intimate what we conceive to be the only natural scries, by arranging the genera, in our synopsis, under the following subfamilics:-1. Frigilline; 2. Corvine; 3. Garrulina; 4.Crypserine; and, 5. Coracine.

(110.) The Corvince, or typical crows, exhibit the greatest perfection, and the most varied powcrs, with which naturc has invested this class of auimals. This superiority consists, not in the extraordinary developement of any one particular organ or quality, but in the union of nearly all those powers which have been separately assigned to other families. This perfection is best exemplified by looking to the economy of the ordinary crows. In every climate, liabitable to man, these birds are found. 'I'hey are as well constructed for powerful and continued flight, as for walking witl a firm and stately pace on the earth; they feed indiscriminately on animals or on vegetables, and, when pressed by hunger, refuse not carrion: hence their smell is remarkably acute. They are bold, but wary, live in common societies, and possess grcat courage: when domesticated, they evince a power of initating the human voice ncarly equal to that of the parrot: while tleir cunning, pilfering, and hoarding dispositions are all symptoms of greatcrintelligence than what is found in any of the families alrealy mentioned. Some of the sinaller spccies so closely resem ble the shrikes, that this analogy lias been taken for an affinity. In the subfanily of Garrulinat, which includes the jays, these perfections are diminislied; for these birds, like bush shrikes, live entirely in wools, and are scldom, if ever, seen upon the grouml: like their prototypes, also, they devour young birds, and arc well known in Amcrica to be great pilferers of eggs, of which they rob the nests of other birds.

(111.) The Glaucopince, or rasorial crows, is the only division of this family we have yet analysed with a view to determine its chief generic types; yet these we can only glance at during the rapid survey we arc now coin- 
pelled to make. As a whole, they are distinguished from

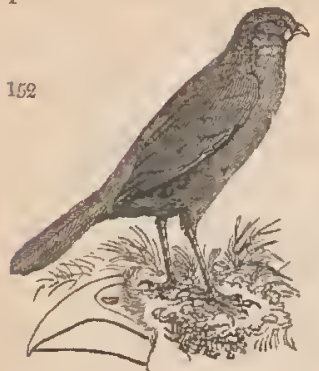

all other birds by their short, finch-like bill, the commissure of which is always arched, and sometimes sinuaterl, like that of a Fringilla. The genus Glaucopis, which is the pre-eminent type, shows us this structure in great perfection (fig.152.), aulderl to another which is equally indicative of the rasorial structure, that is, strong walking legs, Following this wc have the Senegal I'iapec, forming our genus Ptilnstomus , intimatcly related, according to M. Temminek, with his Corvus gymnocephalus $\uparrow$, upon this authority we conjecture the last mentioned bird may prore the grallatorial type. 'T'he singular genus Brachystonza, from New Holland, long since noticerl by us, as connecting this group with the jays, leads at once to the finch crows of India, all of which, in our opinion, are merely variations of that type named Crypsirina by M. Vieillot. $f$ Some of these, from their elose resemblance to Glaucopis, have actually been placed in that genus by M. Temminck, who scems to have overlooked the entirely different structure of their legs. The circle is thus closed, and we find that these five types represent the primary divisions of the whole class.

(112.) The following genera we exclude from this family, where they have been placed by some authors:Epimuchus, as belonging to the suctorial lirds; Corecins. as leing completely united to Eurystomus by two specics now before us, the latter being well-known as a fissirostral group; and Gracula, as united"to P'astor among the Sturnida. The Paradisc birds (Paradisende), hitherto arranged with the crows, form the most aberrant group of our Tenuirostres, and are placed between the hoopocs and the honeysuckers.

* Birds of W. Af. 1. p. 135.

+ P. Col. ph. 327 .

\# As the name of Crypsirina has the priority over that of Dendrosiltu, we have considered it but just to adopt the first, although given to an aherrant species ( $C$. femia) which comects this group with Plilostomus.

VOI. II. 
(113.) From the crows, we proceed to the family of starlings (Sturnida), but the unarranged state of the last group prevents us from knowing the genus by which this passage is truly effected. The various birds assimilated by ornithologists to our Enropean starling, are generally of the same size: they appear, in fact, like a smaller race of crows, which they very much rescmble in manners and in structure: in the latter respect they are evidently much weaker: they seek their foorl generally upon the ground live in societics, and seem universally to preferplains frequented by cattle. The three principal groups are well characterised. In the first, the margins of the bill form a distinct angle at the base, which is rery wide; the gape extcnds beneath the eye, and the tips are slightly notched: these are the true starlings (Sturnince). In the second, the bill is shorter, more compressel, and very much rescmbles that of a thrush, being almost destitutc of the basal angle : this subfamily comprchends the true grakles (Lamprotornince), and is remarkable for the inetallic lustre of its dark-coloured plumage. 'The third, or aberrant division, includes the boat-tails (Scaphidurina), the hangnests (Icterine), and the maizc-birds (Agetaine), all of which are characterised by a perfectly entire'finchlike bill, more or less conic, but of different lengths.

(114.) Commencing with the boat-tails (ScApHIDURI$\mathrm{N}$ E), we have the largest birds in the whole family; those in short, which even a scientific observer might easily mistake for real crows. They derive their conmon name from the singular structure of the tail, which is graduated, and is rendered so concave on its upper surface, by the oblique folding on its sides, as to resemble the form of a boat. All the true species of this group are natives of Ainerica, and resemble the crows in the glossy biackness of their plumage, although they are obviously the rasorial division of this family. But there is a bird from New Guinea, the Astrapin gularis Vieil. (fig. 153.), which, from exhibiting the greatest developement of this structurc, might be taken for the type, did not its bill and general habit evince an approximation to the next 

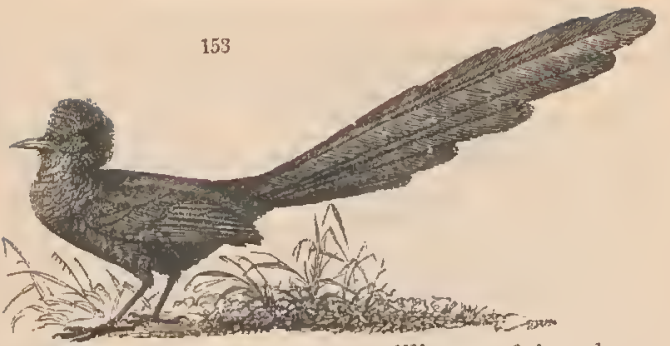

subfamily. The uncommon brilliancy of its plumage has induced all writers, except MM. Temminck and Vieillot, to associate Astrapin with the Paradise birds.

(115.) The Lasiprotonnink, or grakles, comprise many smaller groups, whose characters have not yet been investigated; while others, truly belonging, as we conceive, to this family, have been placed with the crows. 'The magnificent Astrapia just alludel to, but for its long boat-shaped tail, would certainly bc ranked with this group, of which, after all, it may probably prove to be the rasorial genus. 'The chief peculiarities of the grakles consist in a strong thrush-like bill, generally notched, but never angulated at the base; the feet are remarkably large and stout; and to the general blackness of their plumage is adder the most beautiful mctallic lustres of green and blue. The whole group appears coninned to the tropics of Asia and Africa, where they seem to represent the American boat-tails. 'T'o this group we remove the A ustralian satin birds (Ptilonorhynchus Kuhl), and the maniots, since the Pustor musicus at once shows the natural stations and afininities of all these birds.

(116.) To the Sturnina, or truc starlings, the passage is easy and natural; since in the maniots we see many of the characters of the grakles united with those of the Pastor starlings. In the birds of this subfamily ( $f i g$. 154.), the bill is much morc straight, and the under mandible is considerably thickened at the basc, where the commissure forms an abrupt angle. The great strength of the legs indicates the walking propensities of these birds,

$$
\text { 11 } 2
$$


which are well known to follow the tracks of cattle, in

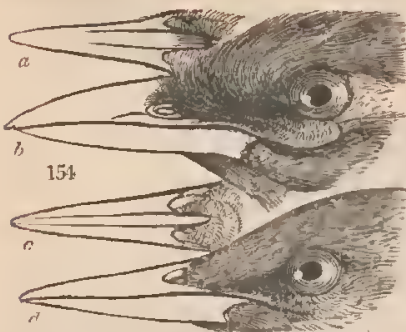
order to search after such insects as are disturbed by their grazing. It is singular to witness the association of crows and starlings in the same field, - nearly in the flock, — and 'almost adopting the same habits; each bird representing the other in itsown particular family : in both, the lengthened and conic form of the bill is well adapted for searching after insects in the ground; both walk in the same statcly manner, and both seem so attached to cattle and sheep as to rest upon their backs. In the genus P'ustor ( fig. 154. $a, b$ ), the bill (as in Lamprotomis) is compressed: but in the European starlings, forming thegenus Sturnus, it is more acute and depressed $(c, d)$; the notch also is so faint as to be nearly obsolete. Some of the foreign pastors, leading to Gracula Cuv., are furnished with naked wattles, and seem providentially created to destroy those devastating flights of locusts which so often appear on the plains of Southern $A$ frica.

(117.) The Agtuan $x$, or maize-birds, succeed to the starlings; the two subfamilies, in short, are so completely united by the Sturnelle collaris, or collared itarling of North Amcrica, that, but for the discovery of the genus Oxystomus, it would be difficult to say in which group Sturnellu should be placed. We now enter upon a group so truly natural, that the confused notions of certain writers regarding their distinctions excites no little surprise. Ignorance of the natural habits of these birds, or a disregard of that peculiarity of structure which would, in some respects, point out their habits, will always produce a gencralising but a very artificial arrangement of groups nearly eonnected, but essentially lifferent. Such, at least, is the only way in which we can account for these birds being considered as part of 
the hangnests (Icterida) by most writers, and actually united to them and the Quiscalinre, all in the same genus! by another.* The fact, howevír, seems to be, that nature has distinctly separated the Ameriean orioles of Linnzus into three great groups, yet that she unites them so completely by insensible gradations, that unless the whole are analysed, their true distinctions will never be detected. America is the sole region of this fanily, no less than of the boat-tails and the hangnests; and we are thus enabled to say something of them from personal observation. Like the starlings, the Agelaince almost live upon the ground; like them they associate in flocks; and like them show a constant predilection for open pastures, and the haunts of men and cattle: whenever, during our travels through the wilds of 13razil, we reached the corals.

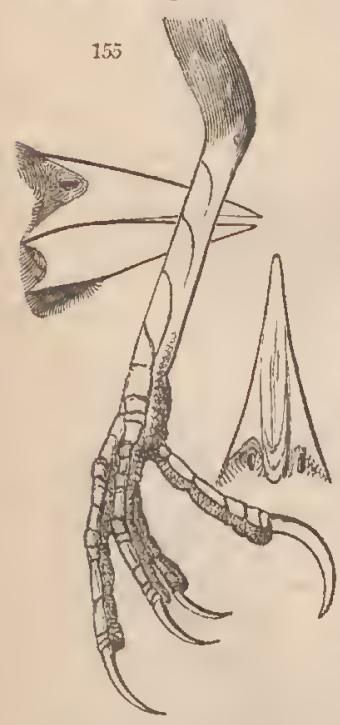

(or cattle enclosures), we were sure to meet with these birds ; of which many species (in general very obscurely known) are found in all parts of that empire. The primary eharacter, therefore, of the maize-birds is, that they are terrestrial, while those of the next family are arborcal; and both these peculiarities are rendered sufficiently apparent by extcrnal structure. In the maize-birds, the feet, like those of the starlings, are strong and lengthened; and the clevation of the tarsi at once proclaims their habits. This structure is carried to its maximum in theMexican Agelaius longipes Swains., and in the Nortl American Ageluiu.

* Wagler, Systema Avium, where, under the generic name of Psarocolius, the whole of the Scaphidurina, Icterina, and Agelaine are looked upn as mere species. 
icterocephalus Bonp. ( fig. 155.). There is still another characteristic of thcse birds : to enable them to retain a firm hold on the smooth stems of the maize and other grain, upon which they feed, their claws arc slender and acute; while the tail (always bent downward when the bird is in such attitudes) is frequently worn at its extremity. In the scansorial genus (Dolichonyx Swains.), this habit is actually accompanied by the scansorial structure of tail, the feathers of which are rigid and pointed. The most interesting genus in this group is the Molothrus pecoris or cow-bunting, of Wilson, the only bird, except the cuckoo, which deposits its eggs in the nests of other birds.

(118.) The 【стеRIN fiftli and last division of this family, and they are so intimately connected with it, that naturalists have not hitherto been aware of their truc distinction. This is also strictly a South American group; gregarious, wary, and ingenious; building long purse-shaped nests, suspended from the slender branches of lofty trees; and feeding on fruits and colcopterous insects : yet, unlike all the preceding gencra, these birds are never seen upon the

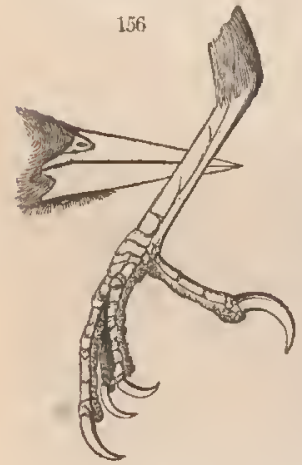
ground: the legs, indeed, are robust, but theyare short, and the claws broad, strong, and fully curved ( $f$ ig. 156.) : the subordinate types are well distinguished by slight but perfectly characteristic differences in the form of the bill, wings, and tail; the full perfection of the group being seen in Icterus, not, as it has been thouglit, in Cassious, which is the rasorial type. That we have now traversed the circle of this family, and have again arrived at the boat-tails, will be apparent to every one who is acquainted with the genus Scuphidura Swains. as now restricted; a bird which has, indeed, becn 
elassed as a Cassicus, - for it has the bill of that genus and the boat-shaped tail of Quiscalus.

(119.) The Afriean beefeater (Buphaga), as we have already intimared *, is altogether exeluded from this family, not only because thie whole strueture of this eurious bird is far lifferent from that so general among the Sturnidre, but beeause its introduction here would manifestly disturb the progressive and eireular series here exhibited. The only reason, indeed, that appears to have influenced all ormithologists in plaeing it with the starhings, is the propensity which both have to frequent the haunts, and perch upon the backs, of cattle. Now, as crows and ravens are well known to do the same, they might, by a parity of reasoning, be elassed in the same group; for a starling is unquestionably more like to a erow, than the beefeater is to a starling. In Buphuyn, we have, in short, the scansorial feet and tail; with the bill (fig.157.a $a$ ) so perfeetly resembling that of the honeyguide $(b \quad b)$, that one of our best ornithologists, without suspecting the affinity, has named a new speeies of honeyguide Indicator Buphayoides! stating

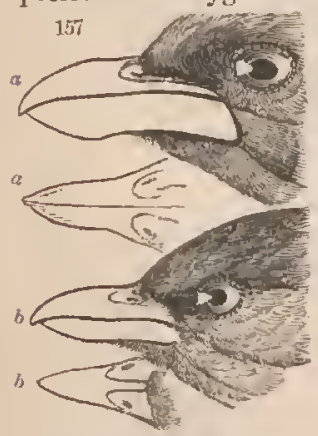
as a reason, that it has " nearly the appearance of the beefeater's bill, partially agreeing in the strong and angulated form so conspictous in that genus." + "This speeies we have personally examined; and if any doubtshad then remained in our mind on the propriety of removing $B u=$ phaga from the Sturnida, they would have been irnmediately dispelled; but we had, in truth, already determined this point, by a careful analysis of the Sturnine family.

(120.) The analogies of the family we have now investigated, whether in regard to the corresponding groups among the Corvide, or to its owu internal relations, are

* Class, of Birds, i. p. 144.

+ Lin. Trans. xvi. p. 91. 
satisfactory and perfect. We shall first show in what manner the Sturnidae represent the primary types of ornithology, and consequently the tribes of the Insessores, or perchers.

\section{Sturnine, or Starlings. - Avalogles.}

Subfamilies.

Analogical Characters.

Tribes of the Insessores.

Sturvis $\quad$ Bill lengthened, more or less conic. Conirostres.

LAMPRotonN1v.R. $\left\{\begin{array}{c}\text { Bill more compressed; the culmen } \\ \text { curved; the lip distinctly notched. }\end{array}\right\}$ Denrrnostres.

Scaphinuranc. $\left\{\begin{array}{c}\text { Tail unusually developed; commis- } \\ \text { sure sinuated. }\end{array}\right.$ Scavsores.

ICTERINA:

$\left\{\begin{array}{l}\text { Bill very slender towards the end; } \\ \text { feed chiefly on soft substances. }\end{array}\right.$

Agelaif.e.

Bill very short; wings long, pointed;
habits migratory.

The analogies between the two typical groups are so perfect, that they hardly require any further notice. The starlings are the most typical of one group, just as the Conirostres are of the other; and both have the most conic bills of that particular modification which is calculated for searching on the ground for insect food; in both also, the upper bill is very slightly notched, - a character which is not found in either of the thrce aberrant groups of the STURNins, although their bills arc more conic than even that of the starlings. The Inmprotornine are distinguished from the last by the great compression and curvature of the culmen or ridge of the bill, where we find the notch as deep as in the thrushes and other groups of dentirostral birds; and it is just by these characters that the Dentirostres are distinguished from the other tribes of the Insessores. In the rasorial groups, the tail is always developer in an unusual manner: this is one of the distinctions of the Scansores; and we find the same degree of singularity, under a different form, in the boat-shaped or concave tails of the Seaphidurina. The most slender-billed birds are wcll known to bc the tenuirostral familics, and the grallatorial waders; while the most slender-billed of the starlings are the Iete- 
rince, or hangnests. Those which have the shortest bills, on the other hand, belong to the typical Fissirostres, - the swallows and night-jars; and such is also the peculiarity of the Agelaince among the Sturnidke. The ornithologist will perecive that the three aberrant analogies, as we have statel on forner occasions, are reversed; for the Fissirostres, and not the Scansores, follow the Dentirestres: but it is equally clear, that the boat-tails, of all the startings, show the nearest affinity to the crows; and that the inaize-birds, Agelaina, evince an affinity, equally strong, to the finches. It is also unquestionable, that our first column - of the subfamilies of Sturnide - forms a circular group, founder upon analysis : we shall not, therefore, attempt to transpose any of its contents, merely to get over an imaginary difficulty in their parallelism with the primary types.

(121.) $\Lambda$ s a second confirmation of our arrangement being natural, we shall now place the subfamilies of the Sturnida opposite to those of the Corvida, and then glance at the results. This table, in fact, will serve as much to verify one family as the other.

Analogies of the Sturnides and the Corvinas.

Subfamilies of the Sturnidas.

Sturnina.

Analogical Characters.

Subfamilies of the Corvide.

Bill lengthened, conic; the notch ind is-
tinct.

Lamprotornina. $\left\{\begin{array}{c}\text { Bill distinctly notched; the culmen re- } \\ \text { gularly curved. }\end{array}\right.$

Scaphidurince. Tail siugularly developed. Glaucopince.

Icterina.

Feed upon soft fruits; feet particularly $\}$ coracince.
short.

Agelaina.

Wings lengthened.

Fregilina.

Starlings and crows, as every field naturalist - nay, every common observer - knows, feed in the same manner, associate in flocks, pick out worms from the ground, perch upon the backs of cattle, and partake both of animal and vegetable diet. Equally perfect is the analogy between the grakles and the jays: they are the most richly coloured group in their respective circles; and 
both, as a whole, have the upper mandible more curved and deeper notehed than any other. It is only among the Glaucopine and the Scaphidurine that we find that unusual developcment of tail so eharacteristic of rasorial types. The Crypsirina temnura in one group, and the whole of the typical boat-tails in the other, verify these to be rasorial types, and consequently analogous. It is at these points that the cireles of the erows and the starlings touch and pass into other; and we thus find that it is here the two groups evinee the elosest affinity: a singular eircumstance corroborating this is afforded by the fact of the commissure of the bill, in both groups, being sinuated in the typical genera. From this point, as the affinities recede of the two families, and become more and more distant, so, as a natural consequence, do their analogies also beeome more remote. Hence, those between the two most aberrant groups, Icturine and Coracina, appear to rest only on the fact of both being strictly composed of arboreal birds, having peculiarly short feet, and living principally upon soft fruits. Finally, the most remote analogy is that between the Agelaine and the Fregiline, because they stand at the confines of their respective circles; and yet, as these two possess the common property of having the longest wings in their respective circles, they must be representations of each other: this structure, we know, is eminently charaeteristie of fissirostral types; so that the cirele of each having now been compared, we find they produee a perfeetly uniform result, adding one more to those innumerable instances we have brought forwarl to demonstrate the LAw of REPRESENTA Tron.

(122.) We shall now throw these two groups into their proper cireles, because the analogies will not only he at once placed before the eye, but because these circles will also illustrate that apparent transportation of groups we have just before alluded to : - 


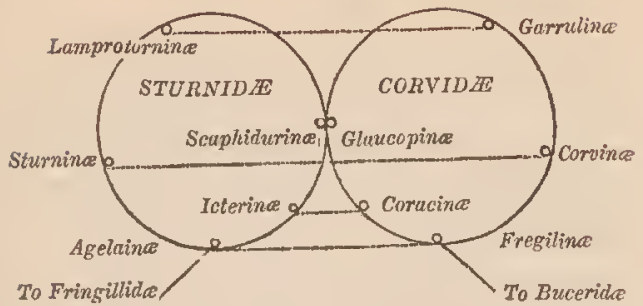

However this transportation may be hereafter accounted for, there can be no doubt that Fregilus is analogous to Agelnius, and that this latter genus evinces the closest approximation to the short-billed finches. With these facts beforc us, we must rest satisfied, and at once proceed to that family which is next in the conirostral circle.

(123.) The lininguluom, or finches, form the rasorial family of the Conirostres. They are, indeed, the smallest in size of any in the whole circle; and this circumstance appears to militate against their being representatives of the large gallinaceous birds; and would rather intimate that they were analogous to the Tenuirostres among birds, and the Cilires among quadrupeds. Nevertheless, although they do not possess this indication of the rasorial type, they exhibit nearly all the others: they have, for instance, the hardest and most conic bills ; they are the most tame, and the most easily domesticated; they feed almost entirely upon sceds; and there are more crested birds among them than in any other family group of the Corirostres. There are also indirect evidences of this anlogy, which can by no means be got over. We have already seen that a graclual shortening of the bill takes place from the typical starlings (Sturnince) to the maize-birds (Agelaince), and that some of these latter so closely resemble finches, that only an experienced naturalist can point out their distinction. Then, upon looking to the opposite group of the Conirostres, it is no less certain that the hornbills represent 
the Fissirostres. Besides, it is abundantly evident, throughout the animal creation, that all rasorial groups do not posscss the whole of those characters which belong par excellence to the type itself; for in the very next tribe to this, we have the equally small sized Sylviadee, although they unquestionably form the rasorial division of the Dentirostres.

(124.) The general characters of this family are too well known to every one at all acquainted with birds, to require an elaborate exposition. The sparrow, bunting, greenfiuch, goldfinch, all our little thick-billed birds, in short, form a portion, and give a very correct idlea of the general character, of this family, certainly the most extensive in their number and interesting in their habits of all the couirostral groups. In general appearance they may be distinguished as having the bill remarkably short, very conic, and cousequently very strong. In only one of the divisions (the tanagers), do we find that the upper mandible is distinctly notched and bent over the lower. This structure is contimued to a few birds, which border upon the group of tanagers, such as the sparrows; a structure which indicates a mixed diet of insects and seeds. In some the colours are uncommonly rich, and beautifully combined; but in the majority, and entirely among the ground finches, the plumage is dull and homely. Finches are dispersed over all the temperate, and even in the arctic, regions of the world ; since, whereever vegetation exists, sceds are produced; and these are the chief, if not the only, food of the Fringillida. Nevertherless the different minor groups, as wc shall presently noticc, have different rcgions assigned to them. The fect are always perfect,-that is, there are three toes before and one behind, all of which are cleft to their base, - so that the birds may freely move both upon the ground and among trees.

(125.) The primary divisions or subfamilies will now be slightly characterised. The typical group is that of Coccothraustina, composed of the hawfinches, weavers, goldfinches, and linnets. They live cntirely 
among trees, and have the bill very strong and entire. The second, which is the subtypical, contains the Tanagrince, or tanagers, alrearly alluded to as having a distinct notch at the tip of the upper mandible: thesc also are almost entirely arboreal. 3. The Fringilline, or true finches, differ materially from the two former: they have generally much smaller, but nore perfectly conic, bills ; their food consists almost entircly of seeds; and they chiefly live upon the ground. The fourth includes only the larks, or the Alaudina: in these the bill is much more slender than in any of the preceding, and the hind claw is always more or less lengthened. The Alaudine pass into the Pyrrhuline, or bulfinches, having a veryshort, thick, and swollen bill, inuch curved above, and whose habits lead them to frequent trees. Comparing these subfamilies with those of the Sturnida, the last group we investigated, we shall find they represent each other in the following manner : -

\section{Fringlhide and Sturnid a. - Analogies.}

Coccothraustina. $\left\{\begin{array}{c}\text { Typical of their respective circles: } \\ \text { notch of the bill small or obsolete. }\end{array}\right\}$

Tanagrince. $\quad \begin{gathered}\text { Bill arched sbove, and distinctly } \\ \text { uotched. }\end{gathered}$

Fringilline. $\quad\left\{\begin{array}{c}\text { Palate of the mouth with an internal } \\ \text { knob. }\end{array}\right.$ Scaphidurince.

Alaudina. Bill lengthened and siender. Icterince.

Pyrrhulina. Bill very short. Agelaina.

We cannot afford space to enlarge upon such of the analogies as are evident; those, for instance, in the second, fourth, and fifth lines; but although there is no striking external character shared in common by the Fringilline and the boat-tails (Scaphidurince), yct it is wonderful how these two groups represent each other; for the Seaphidurine actually possess that internal bony protuberance in the roof of the upper mandiblc, which so peculiarly distinguishes the genus Emberyza from all the finches: a character, moreover, which is only found in the opposite column among the boat-tails We shall 
now take a hasty survey of each of these primary divisions.

(126.) The Coecothraustina, or, as they may be called, the hardbills, are the most typical of all the finches, inasmuch as they comprise tliose birds which possess the largest, the most conic, and the most powerful bills. The whole group is arborcal, - that is, they contain such birds only as live entirely among trees, and which to not, like the sparrows and buntings, frequent the ground in search of their fool. Our well-known hawinch (Coccothraustes europecus), although not a strictly or preeminently typical example, will nevertheless convey avery good idea of the general structure

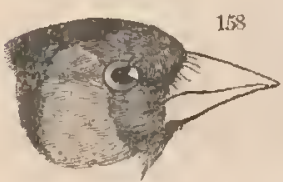
of these birds; and the greenfinch (although even less typical) is no bad example. 'The other native birds which enter into the aberrant genera, arc the goldfinches and the linncts. In all these, as well as in nearly all the foreign hardbills, the upper mandible is entire. The whole of these birds are arranged under the five following genera: -1 . Coccothraustes; 2. Ploceus; 3. Tiaris; 4. Carduclis; and, 5. Linaria; the last of which is connected to the first by means of the green linnet (Frimyilla chloris of authors), which is immediately followed by the European harvfinch, in the typical genus Coccothranstes. No affinities can possibly be stronger: and this at once closes the circle. The grenus Coccothranstes scems to be distributed in all parts of the world; and its modifications are so remarkable, that we have ventured, after a very close analysis of the group, to designate its subgenera: at the liead of the these, and consequently of the entire family, stands the subgenus Pyrenestes, at present composerl of only three or four birds, peculiar to the littleknown regions of 'Tropical Africa, where many others, no doubt, remain undiscovered. 'Their bill ( fig.3\%.Vol. I.) is truly enormous, considering the size of the boty; for it is frequently as deep and as large as the head, and must be 
employed to break the hardest nuts. In the corresponding latitudes of America we have the subgenus Coceborus, which is united to Pyrenestes by the Irazilian C. magnirostris (fig.159.), or the Loxin angolensis of the old writers. This type is inferior in its bill only to the last, while some of the species so closely resemble the genus Pitylus among the tanagrers, that they can only be distinguished by the notch of the bill being very slight, or almost obsolete. Coccothruustes appears restricted to the temperate latitudes of Europe, America, and Asia: all the specics have long wings; and they appear to bc migratory. The two other supposed types arc African, and at present but little known.

(127.) Thegenus Ploceus is by far the most numerous, as

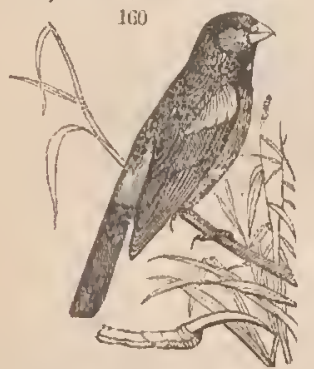
well as the most beautiful, of this division (Enplectes cupenis, fig. 160.). It is composed of the weavers, a name given tliem on ac count of that surprising slill with which they fabricate their nests; a circumstance of which we have already spoken more at large.* We have long had suspicions that this, in truth, is the typical genus of the present subfamily, because it is among these birds we find by far the greatest intelligence and the most social habits, - qualities which are so pre-cminently typical of rasorial groups; and it must be rcmembered that the Fringillide, as a whole, is the rasorial family of the Conirostres. On the other hand, we must not overlook the circumstance that the weavers feed as much upon insects as upon seeds, - a fact, indeed, which rests not 
merely upon the assertion of travellers, but on a peculiarity of structure: the margin of the upper mandible is so much sinuated as frequently to produce on each side an absolute festoon, like that seen in the typical tanagers, and which is obviously intended to break in pieces hard coleopterous insects. As we have elscwhere* entered into many details regarding the subgenera of Ploceus, the reader must be content with a hasty glance. The typical species are the largest, and have the longest bills. In Euplectes, we have some birds of the most brilliant scarlet and black plumage, remarkable also for the great

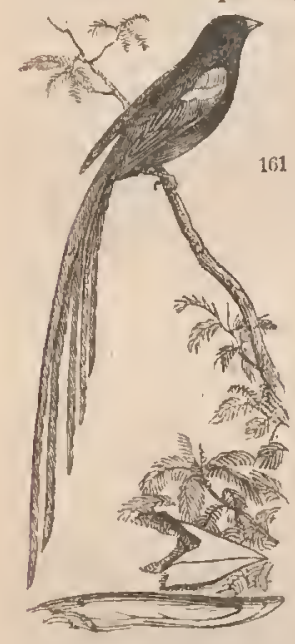
size and slenderness of their feet. Vidua presents us with those elegant finches peculiar to Western $A$ frica, the males of which, in the breeding season, are ornamented with tails of an extraordinary size and structure, as in Vidua phenicoptera Sw. (fig.161.). Can this group represent the Paradiseada? We confess such was once our opinion; and yet we cannot discover how they can be removed from the situation we here assign them, so as to bring them in as the tenuirostral type of the Coccothraustine, - a rank we have, for the present, assigned to Carduelis. Leaving the genus Ploceus, of which the foregoing are the most prominent forms, we come to the American group of Tiaris, a small assemblage of pretty little birds, most of which, as the name implies, arc crowned with crests. All the species appear peculiar to America; some show an affinity to Ploceus, others to the small tanagers ( $N^{\top}$ emosia), while two or three from Brazil closcly resemble the goldfinches. Thus conducted

* Birds of Western Africa, i. p. 158. 


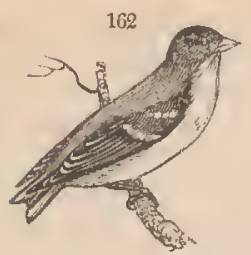

to Carduelis (C. Americana, fig. 162.), the passage is easy and natural to Linaria, in which there are certainly three or four subgenera: one of these is represented by our greentinch (Chloris). This genus, as already rcmarked, learls ímmediately to Coccothraustes, and thus closes the circle.

(128.) The TANAGRIN $\$$, or tanagers, is probably that group which is the most numerous, asitcertainly is the most diversified, of all those in this comprehensive family. As the dentirostral division of the Fringillide, it is typically distinguished from all the others by the bill having a distinct and well defined notch at the end of the upper mandible, the ridge or culmen of which is much more curved than is the gonys; or, in other words, the culmen is more curved downwards than the gonys is upwards: this inequality, as in the genus P'loceus, very much takes off from that regular conic form of bill so highly characteristic of the greater number of the finches; so that the combination of these two characters is, perhaps, the best distinction of the whole group. Another peculiarity of these birds consists in their geographic range; for the whole, so far as has yet been ascertained, are natives of the warmer parts of $\Lambda$ merica, abounding most in those regions which lie nearcst the equinoctial line. They are in general sinall birds, - the largest being intermediate between a sparrow and a thrush, while the majority do not excecd the size of a linuet; some few are even smaller. It is quite evident, from thc grcat strength of bill possessed by some, and the notch, which is conspicuous in all, that these birds feed both upon secds and creeping insects, picked from the branches of trees; for very few of them arc ever seen upon the ground. Their colours in general are bright; and, in a large number, particularly rich and beautiful. 'The little birds forning the genus Aglaiu, in fact, are ornamented with 
the most vivid hues, or glossed with rich reffections of goll, rendering them inferior only to the humming birds. Some possess considerable vocal powers; and the notes of the subgenus Euphonin, as its name implies, are said to be particularly musical. The impossibility, however, of providing the tanagers with their native insect food, has prevented them from evcr being brought alive to the Furopean menagcries, to which their beauty would render them the greatest ornaments.

(129.) It might be supposed, that the internal arrangement of a group, distinguished by so many peculiaritics, hoth of structure, colour, and geographic distribution, would be by no means difficult; yet the very reverse of this is the case. We may safely affirm, indeed, that it is one of the most difficult to be understood in the whole circle of ornithology: nature scems to have departerl, in this groip, from that uniformity of progression which is so prevalent in all her works: this remark is not applied merely to the smaller groups, but actually, in many instances, to the succession of species. The comparative strength of the bill, for instance, is so variable in birds of the same subgenus (the lowest denomination of groups that we can tracc), that this variation, indicative of genera in other families, is in this no more than a discrimination of sections or specics. Nothing can illustrate this fact more than the affinity hetween Pitylus (fig. 163. b) and Tardinola. Looking to the typcs of each, we should say they did not belong even to the same subfamily; for the hill of the first is nearly as large as in the hawfinches (Coccothraustes), while that of Tardivola (a) is so comparatively slender, that it seems more akin to the larks than to the tanagers: and yet, between thesc two extremes or types, we have now before us such a perfect serics of graduated forms, wherein not only the bill, but all the other subordinate characters of the two groups, progresses in such a beautiful and almost imperceptible manner, that we are actually at a loss to know where Tardivola ends, and Pitylus begins. No 
wonder, then, that some of our' best writers, who seem to be aequainted with one or two of the typical examples of Tardivola, should place it as a genus, in a totally different family. 'To illustrate this extraordinary union of two subgenera (apparently so widely separated by characters whieh are usually considered indications of higher divisions), we subjoin the outlines

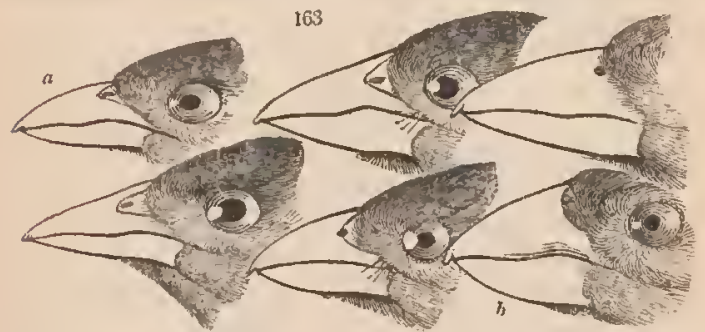

of the intervening gradations in the form of the bill just alluded to, and which will bear us out in the belief, that, whatever uneertainty hangs over other parts of our arrangement of the tanagers, the proximity of Tardivola to Pitylus is beyond dispute.

(130.) This foregoing affinity being admitted, we are next to inquire into the cause why such a remarkable variation in the bill should occur in speeies so closely united. Now, it should first be stated, that nearly the whole of the seed-eating birds of Tropical Ameriea are composed of the tanagers, which, in those regions, supply the place of the other finches, so abundant in all parts of Europe. The seeds and hard berries, however, found in our cold and temperate elimates, are very few indeed, when compared to the innumerable variety produced in the vast forests of the New World, whether we regard the variety of the species, or the different degrees of lardness they possess. Now, as these small and hard fruits are the appointed food of the tanagers, (for the parrots chiefly subsist upon the larger nuts, ) it follows, that an equal diversity of strength should be found in the bill; that organ, in 
fact, which is to turn these seeds into nourishment. If there was little variation in the size or strength of the bills of the tanagers, the inevitable consequence would follow, that they would only be able to feed upon seeds or nuts varying but very slightly in their size and hardness: and hence it would follow, that innumerable other sorts, which either did not come up to this standard, or much exceeded it, would be left untouched, and, as food to the animal world, perfectly useless ; at least, so far as we can conjecture. To prevent, therefore, such a waste of her vegetable aliments, nature lias created in the finches a vast family of birds, expressly for the purpose of subsisting upon them; and that these birds should be qualified to partake of all the different sorts, from the softest to the harlest, she has given to these ereatures a corresponding variety in the shape and strengtl of their bills. $\mathbb{T V}_{\mathrm{T}}$ are much strengtliened in this hypothesis, by observing sometling of the same principle in operation, although, upon a more limited scale, among the finches of Europe. How great, for instance, is the disparity of size between the bill of our hawfinch, greenfinch, and linnet; and yet these birds, so far from belonging, as is generally supposed, to very distinct and even remote genera, actually

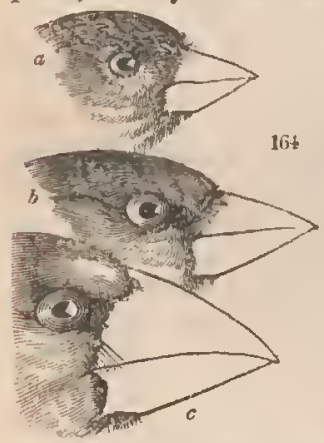
follow each otler (according to our analysis of their affinities), without the least interruption, as subgenera. Every one, in fact, must perceive the close relation of the common linnet (Linaria, fug. 164.a), to the green linnet (Chloris, $b$ ), and this again to the hawfinch (Coccothraustes, $c$ ), with which it might, perhaps, be equally associated, as only a slightly aberrant species. Such a disparity in regard to the bills can scarcely be found in any other groups in ornithology. 
(191.) We thus account for the little reliance that can be placed on the mere size of the bills of the tanagers, for determining thcir gencra; but this will not explain the great difference which often takes place in the size and plumage of species, which all writers agree in placing within the limits of the same subgenus: we might take the restricted genus Pitylus of Cuvier as an example of this, where some of the species are green, some black, and others grcy ; and they vary from the size of a sparrow to that of a small thrush. We cannot be accused of not favouring the adoption of new genera, all yet we are compelled to cancel that of Cissopus, from our present conviction that it is a mere sectional represeutation of Lanius in the subgenus Pitylus, which stands at the head of the tanagcrs. The recent

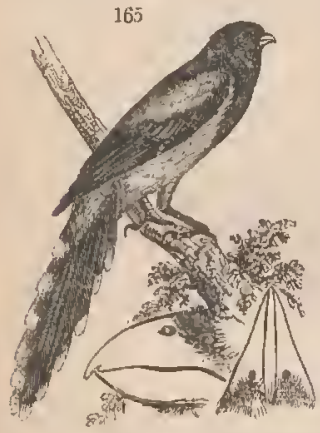
discovery, in fact, of its prototype, in the subgenus Lanius itself, may be said to demonstrate this view of the subject; for a shrike, discovered by Dr. Smith in South Africa, is so completely like Cissopus (Pitylus picatus, fig. 165.), that, but for thcir bills, the two birds might be easily mistaken for the same species ; both, in fact, are miniature magypies, and both represent that well-known birl in thcir own circles.

(132.) We shall now give a rapid sketch of the views we at present cntertain of the natural affinities of these birds, first briefly stating the doubts that still hang over their corrcctncss. These doubts, indeed, may be sail to linge almost entirely upon our not having been ablc to exannine specimens of the Fringilla Zena of authors, - a birl whicl, strange to say, seems not to exist in any of our public museums, and which we have in vain endeavoured to procure for our own. There are several peculiarities in this remarkable finch, which 
lead us to suspect that it forms the type of one of the principal divisions among the tanagers, or that it connects our genus Aglaia with Pipillo. On the first supposition, $F$. Zona would constitute the passage from the true sparrows (Pyrgila) to the subgenus Tanagra proper; while, by the second, Pipillo would stand intermediate between Aglaïa and Tanagra, and thus constitute the rasorial genus of the whole subfamily. 'l'his latter arrangement certainly appears to us the most likely to be the natural one, in which case, $F$. Zena; will be increly a subgenus, either of Pipillo, or of Aglaia; or, in other words, will connect the two. Neither can we, by any disposition we have yet made, discover the circular series of the types of form in the genera Tanagra and Phomisoma, chiefly from ignorance of the real affinities of Arremon: but for this, - and supposing the tcnuirostral types of these two genera to be undiscovered, - we feel some confidence in the series in which we have disposed the remaining groups. IVe take this opportunity of soliciting, from any of our ornithological readers, the use of a specimen of $F$. Zena, or of those few species which seem to possess the same form.

(133.) The following arrangement of the tanagers, under the foregoing difficulties, must therefore be looked upon for the present as provisional. We consider that the two typical groups or genera are Tanagra and Phonisoma; while those which we think aberrant are Nemosia, Aglaïa, and Pipillo. It is only between the two last of these, that we cannot as yct discover any affinity, at least, sufficiently strong to justify the belief that these five genera form a circle or more or less complete ;" the difficulty, as before stated, being low to connect Aglaïa with Pipillo. In taking a slight review of these genera, we shall begin with Turdivola, whose absolute connection to Pitylus has been already provel. We then proceed to the restricted group of Tanagra, where we have all those beautiful birds of a cinereous bluc colour, so many species of which we 
have already figured* : these appear to pass into the

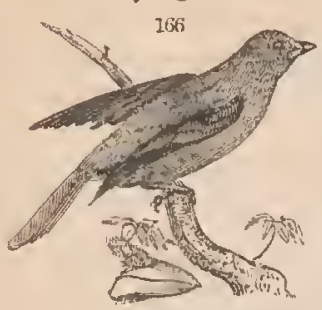
subgenus Ramphopis ( $R$. coccineu, fig. 166.), by means of Lamprotes: and here (unless Aremon forms the teuuirostral type of this division) the genus Tanngra terminates. In all these foregoing types, the bill is more or less shorter, stronger, and thicker, than in the next genus, Phanisoma, which seems to be chiefly distinguislyed from all the subgenera of the last, or Tanagra, by a much more lengthened and a more slender bill. We enter Phomisoma by the very singular form, now first naned Lamprotes : its long wings, short feet, and glossy plumage, seem to point it out as a tissirostral type, while the short and soft frontal feathers remind us of Ramphopis. After this, we place the Phonisome proper, or the red birds, many of which have long wings, and all, like Lnmprotes, have the bill lengthened: from these to Tachyphonus, the passage is very gradual. Tachyphonus is chiefly distinguished by its lengthenerl conic bill, compresserl on the sides, and often distinctly festooned in the middle of the upper mandible. The genus Lanio of Vieillot is obviously only a typical species of this subgenus, and we, therefore, do not adopt it: in the aberrant species, such as $T$. niger-

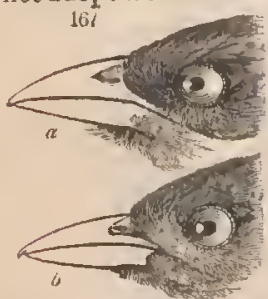
rima, and some others, this festoon disappears; and we are thus preparel for Leutopygia, a new subgenus, characterised by having the bill short, much compressed, and quite entire (fig.167.a). It is by this form, altogether peculiar from itsentire bill, that we suspect the geuus Phoenisma passes into the next. Such 
are the internal types of form which appear to constitute some of the subgenera of Tanagra and Phonisoma: botli, collectively, comprehend all the largest of the tanagers; and they are, in general, so well marked with nearly all the characters of the family, tbat the experienced ornithologist will be at no great loss to distinguish them. We shall now proceel to the remaining groups.

(134.) The aberrant TANAorinse, according to our present views, are comprised in the genera Nenosiu, Agluia, and Pipillo: these we sball shortly notice. It seems evident that Leucnpygia is the most aberrant form among the Phonisoma : its unusually strong feet, with its short, entirc, and compressed bill, leave us in no loubt that it is of the rasorial type; but whether it enters among the last-mentioned genera, or into the first of the aberrant groups, that is, Nemnsia, is a matter of much uncertainty. The ncarest affinity to this, in the genus we have just quitted, appears to be shown by $T a$ chyphnnus aurioapillus*; while, on the other side, this bird seems to be equally related to Nemosia ( $f i g .167 . b$ ). This genus, - which, from its wings being longer, or at least more pointed than in any others, we take to be a fissirostral type, -is composed of vcry small slender-bodied birds, so much resembling warblers, that they have been classed as such by all writers; and even M. Vieillot, who has himsclf proposed the genus, has actually described the most typical specics under the name of Sy/via rupicapillu.t They are distinctly separated, however, from that family, by the thickness of their under mandible which is fully as stout as that of the upper: the feet are small, and ratler short; and the wings, which reach to laalf the length of the tail, have the first and second quills but very slightly abbreviated. These appear to be the typical distinctions; but as it is by this genus that the tauagers, to all appearance, pass into the haw-

* The Tanagra auricapilla of prince Maximilian, and the T. Suchit of our former Monograph.

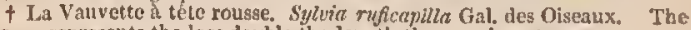
figure represents the legs double the length they are in nature. 
finches (Coccothraustina), by means of the little genus Tiaris already mentioned, so we find many birds which exhibit a union of the characters of both. The bill becomes more conic, and frequently entire, but the wings retain their pointel form, or rather the external quill is very slightly abbreviated. One species in our possession has so much the structure and habit of Leucopygia, that, but for a very minute and scarcely perceptible notch near the tip, and the abbreviation $f$ the inner toe, we should have had no hesitation in associating it with Leucopygia rather than with Nemosia. The next genus which appears to succeed in the series of forms is Aglaza, which is ccrtainly one of the most luatural groups in the family, whatever difference of opinion may exist regarding its true situation. It is composed of the smallest and the most beautiful of all the tanagers; and is chiefly distinguished by a small, short, but somewhat thickshaped, notched bill, with the frontal feathers very short, thick-set, and almost conccaling the nostrils; the feet are small; the wings rather lengthened and pointed; and the tail even. Some of these characters belong to Nemosia, whose more lengthened and slenderer bill is possessed by the Tanagrella tenuirostris * hereafter described; a bird which, on account of its peculiar bill, we have separated from the typical species. Euphonia, for the same reason, may form another sulggenus, well distinguished by the bill being uncommonly broad at its base, and suddenly compressed on its sides. Whether we are to consider the Fringilla Zena as another type of form, or subgenus, in this group, must be left for future investigation; but a bird in our collection, having the bill of Euphonia, but the colours and markings of F. Zena, excites a strong suspicion that both are counected by affinity; and yet, even admitting this, we are at present quite umprepared to show any relation between the types of Agluia and Pipillo, the last genus which we place in the circle of the Tanagrince. Pipillo (fig.168. a) evidently plartakes as inuch of the finclies as of the tanagers. 


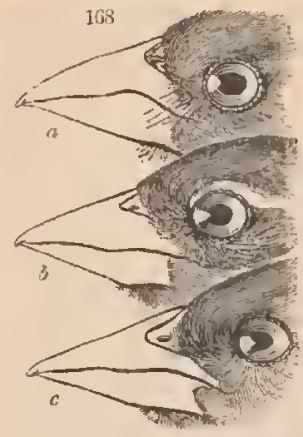

their close connection.

Like Arremon ( fig. 168.b), its bill has the more conic form peculiar to the former, although its bright colours, and the small notch in the upper mandible, give it an appearance of belonging to the latter. T'hat Pipillo is either the last form in the tanagers, or the first in the finches, we consider to be beyond all doubt ; while the strong muthal resemblance of Pipillo arremon and Tardivola (c) shows Upon a former occasion " we associatcd Pipillo with the finches; but more consideration, and the acquisition of two or three new species from Brazil, - one of which evinces some relationship in size and structurc, although not in colours, to Agläa, induce us to remove the group within the circle of the Tanagrina. These spccies we shall subsequently describe; and, having now candidly laid before the scientific reader the few difficulties which at present impede our further analysis of this interesting group, we shall at once proceed to the next.

(135.) The Frinorutise may be corrcetly termed ground finches; since, with scarcely any exception, they are all birds which habitually walk or hop in such siuations, and derive their chief sustenance from seeds of grasses and other plants. Like thic generality of birds which live upon the ground, the plumage of nearly all the Fringilline is of an earthy colour, that is, of different shades of brown, variegated with blackish spots or markings; while their legs are light coloured. These peculiaritics, although they cannot be well taken as strictly scientific characters, are yet so prevalent in this group, that the very aspect of the individuals, to the experienced eye, will at once show to which of the primary divisions of this family they naturally belong.

$$
\text { * North. Zool. ii. } 860 \text {. }
$$


The geographic distribution of these birds is chiefly in the cold and temperate regions of Europe, Asia, and North 'Amcrica ; very few, in comparison, are found in South America; and none have yet been discovered in Australia. The sparrows, the lumtings, and the chaffinch, of our own country, eome within this circle, and afford a good idea of the whole group.

(136.) The two typieal genera of this subfamily are Fringilla and Enberyza: the three aberrant appear to be Pyrgitu, Plectrophanes, and Agrophilus. Some uneertainty hangs over the rank of the latter; that is to say, whether it is the represeutative of a subgemus or a genus, in the sense in which we usc these terms. As for the others, they may be considered as demonstrable, although we cannot afford the space nceessary for proving them so. This, indeed, is hardly necessary; for the gradations of forms between the sparrows (Pyrgita), chaffiches (Fringilla), buntings (Emberyza), and long*

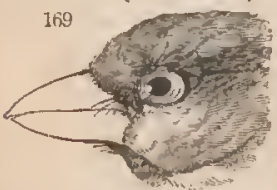
heels (Plectrophanes,) are well known to every ormithologist who is aequainted with these groups. The sparrows (Pyrgita), as being that genus which borders upon the tanagrine circle, is that only whieh has the upper mandible slightly notehed, and the culmen rather more curved than the gonys ( $\mathrm{fig} .169$. .). So little attention has been hitherto paid to these birds, either by collectors abroad, or naturalists at home, that comparativcly very few species are yet known. The great similarity of plumage which runs through them has perplexed our systematists, while the dulness of their eolours has deterred the professional eollector from transmitting them to Europe as articles of profit. Hence it is that we cannot, as yet, point out, with any degree of eertainty, the subgenera. Not so, however, with the genus Fringilla, of which we have ventured to designate four of the types, namely, Fringilla, properly so called; Zonotrichia, the American chaffinehes; Ammodramus, the sandfinches; aud Chon- 
destes, the cornfinches. The fifth type is probably represented by the Fring. Iliaca of Wilson. (pl. 22.f.4.) The discovery of a most singular bird from the interior of Brazil, having the general structure of Ammodrumus, but with the bill of Emberyza, cstablishes the passage from the chaffinches to the buntings: this subgenus we have namerl Leptonyx. We long suspected that the buntings of $\Lambda$ sia and Africa formed a distinct group from those of Furope; and we have now separated them, under the name of Fringillaria. Of Plectrophanes, there are only three or four species, the most beautiful of which is that which has been figurel ${ }^{*}$ under the name of $P$.picta; while the best known is the snow bunting of America and Europe. We have recently procured a specimen of a very curious African bird, tenned a Placens, by Dr. Rüppcll, but which cvidently belongs to this subfamily: its claracters, however, particularly in the bill, will not permit its being associated with any known genus; and, as it scems intermediate betwcen I'lectrophanes and Pyrgita, we have, for the present, so placed it in our arrangement, under the generic namc of Agrophilus.

(137.) The Alaumin \&, or larks, are clearly united to the ground finches by the genus Plectrophanes, which has the bill of Emberyza united to that structure of foot so peculiar to the birds composing the present group. The form, indeed, of the larks is so peculiar as to prevent their being confounded with any of the conterminous groups. 'The bill is still conic, but it is conspicuously lengthened and sleuder; while the legs, exclusively formed for walking, have the claws uncommonly straight and lengthened, more especially the hinder one. Four of the sulgenera are strikingly characterised; but thefifth, or that which leads immediatcly to Plectrophanes, is still undetcrmined; very probably it is the genus Alauda, represented by the common skylark, where the wings are pointed and the tail forked ; but in Calendula both these members are rounded. The crescent larks of Africa are distinguished

* North. Zool, ii.,pli, 49. 
${ }_{170}$ - by their bright yellow or orange

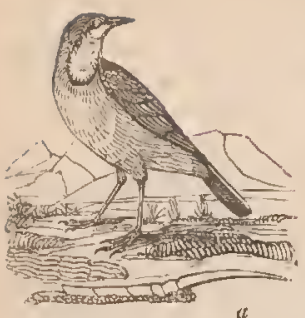

throat, and have received the generic name of Macronys (11. Capensis, fig. 170.). From the enormous length of their himl claws, (a) they obviously represent Sturnella in the circle of the Agelaina (fig.155.); and, if the twogroups are compared, they will be found in parallel situations. The genus Certhilaudn differs from all the foregoing by the length, slenderness, and curvature of its bill: this leads us to suppose it is the tenuirostral type, for it is certainly more removed from the typical larks (Calcndula) than any form yet discovered. Myrafra and Brachonyx, according to our analysis, appear to be aberrant spccies between Calendula and Agrodrom a, and are therefore not primary forms. Hitherto uo example of this subfamily has been found in Tropical America, although one or two specics, common in the Northern States, seem to come into the fissirostral genus Alauda.

(138.) 'The Prrreuninde, or bulfinches, is the last division of this family. Their very short bill, the breadth of which, unlike nearly all the other finches, is often greater than its thickness, together with the large size of its head, and the slortness of the feet, seem to point it out as the fissirostral division. In addition to these characters, nearly the whole of the genera have the commissure of the bill very much curved, and the upper mandible, or rather the culmen, arched from its base. The first genus we enter upou after quitting the larks, is Pyrrhulauda, a little group of hirds peculiar to the tropical regions of $\Lambda$ frica and India, exhibiting the feet of a lark with the bill of a Pyrrhula: to this genus we originally gave the name of Megralotis *, on account of the great size of the ears, or rather of the space over which the ear-feathers spreal; but as that name has becn already given to a division of the genus Canis among quadrupeds, 
we now substitute that of Dr. Smith's. This group seems to lead to the typical genus Pyrrhula, of which our common bulfincl is a good cxample. We do not now consider the American species, or the genus Corythus of Cuvier, in any other light than as aherrant examples of this typieal form; the latter birl obviously leading to the genus Psittorostra, of which only one example, found in the Pacific Islands, is yet known, Crithngra is rather a numerous genus, ncarly all the species being green above and yellow beneath, confined to the Old World; while the crossbills, constituting the restricted genus Loxia, seem more allied to this group than to any otler among the Fringillida.

(139.) The Musopiname, or plantain_eaters, according to our arrangement, constitute the fifth great division of the conirostral tribe of perchers. We denominate the groul after the most conpicuous genus which it contains, although it is by no means clear that is the real type of the whole family. As intermediate between the finches and the hormbills (the first being the smallest, and the' second the largest birds of this tribe): we consequently find a similar disparity in the bulk of the different birds whieh enter into this family. Those which betray their affinity to the bulfinches are small; while others, whose size and peculiar structure assimilate them more to the hornbills, are of a size proportionate to those birds. With the exception but of one genus, they all possess a short, but very strong and thick bill, more or less curved on the top; the cutting margins being minutely serrated, like the teeth of a saw : by this structure the Chilian Phytotoma, as we are informed by Mollini, "cuts off" the plants upon which it feerls, close to the ground, as if it had been done with asaw :" now, as this serrated bill is characteristie of nearly the whole family, it seems to imply an economy altogether peculiar to this group. The food of this remarkable division of birds seems to be purely regetable, and of the most tender and delieate deseription : the violet plautain-eater (Musophaga) is stated by M. Isert, its first discoverer, 
to live principally on the fruit of the $M u s a$, or plaintain tree; while the touracco birds, according to M. Le Vaillant, feed only upon soft fruits. It is singular to observe that the bill in this family (in outward appearance much stronger than that of the finches) should yet be einployed in procuring the softest vegetablc food; while the short bill, posterior nostrils, hopping gait, and purely vegetable food of Musophagn and Corythaix, are all exemplified in such birds as Buceros galeatus*, and proclaim the affinity of the plantain-caters to the hornbills. The old Linnean writers, indccl, scem to have had much clearer notions on this subject than some of the moderns; for Dr. Shaw, in his last work, places Musophaga close to Buceros, and even points out its affinity to the touracco birds (Corythaix).

(140.) On looking to the feet of this family, nature appears to have varied their construction in every possible manner, - a clear proof that cliaracters drawn from these organs often descrve only a secondary consideration. It is always in tenuirostral groups, whether large or small, that the greatest variation of the toes is observable. The whole of the waders furnish a striking example of this fact: and we scc it again in the Halcyonidee, in the genus Apternus, and other minor divisions. In fact, this variation must inevitably take place somewhere, or the feet of all birds would be the same; and we accordingly find it in thosc groups which are equidistant from two different types, and this is precisely the situation of the tenuirostral type in ornithology. But to proceed. In the genus Colius, we have all the four toes brought forward: in the touracco birds (Corythaix), the outer toe, as we have already so fully explaincd $t$, is capable of an outward direction. In Phytotoma, the four toes appear to be arranged like those of the finches; but in Hyreus (fig. 171.), the very next genus, the toes are only three. No two gencra, in fact, agrce in the formation of their feet; yet all present such a peculiarity of

* Lin. Tr. xir. p. 579 .

+ Class, of Birds, i. p. 151. 


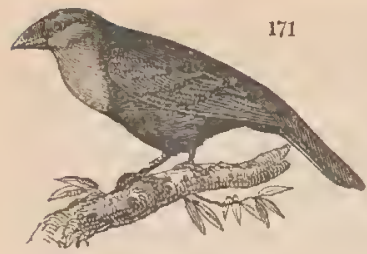

general structure, that the unprejudiced zoologist immediately perceives they form a truly natural group.

(141.) The economy of these birds, so far as they have been observed by travellers, is directly against the theory of their boing likened to the gallinaceous order. The Chili plant-cutter builds on the highest trees; while the African touracco (Corythaix Ill.), whose manners particularly engaged the attention of the indefatigable Le Vaillant, perches only at the extremities of the highest branches of the forest trees, larely descending sufficiently low to come within gunshot. As to the anatomical structure of the touraceos, the admission of M. Cuvier, that they only prescnt "quelque analogie avee les gallinaces;" for that the external toe is versatile, and they have not the notched sternum of those birds, is directly opposed to the theory of these birds learling to the $\mathrm{Gal}$ linacea, and if this needed further confinnation, it is corroborated by a remark by Mr. Yarrell, who dissected a touraceo, living some time in the Zoological Gardens.*

(142.) It is clear, from the foregoing remarks, that the apparent disproportion of size in the birds we associate in this group is not greater than what would be expected; and, indleed, were it otherwise, we might fairly entertain doubts whether our arrangement was eorrect. Between a family of small birds like the Fringillide, and another of such large ones as the Buceride, there should be a graduated seale, or at least some in the intervening group should be small, some middlesized, and some large. Now, this gradation actually takes place in the birds composing our present family. The size and entire aspect of Phytotoma is that of a bulfinch. Colius also, in this respect, as well as in its bill, unites the character of a Fringilla and a Musophnga. Hyreus, a bird we have not scen, and of which no speci-

* Zool. Journ. No. xv. p. 319. 
men, wc believe, is in Europe, appears to be rather larger than a thrush; some of the touraccos, forming the genus Corythaix, are not larger than a magpie, and are fully equal to some of the small hornbills; while C. gigantea, the last of the group, is not inferior to the midlle-sized Buceride. The Buceros galeatus, already mentioned, is probably a distinct type in its own family; and seems to be that which, both in form ani habits, - for it is described as entirely frugivorous, - completes the union of the two families.

\section{CHAP. IX.}

ON THE TRIBE OF SCANSORES, OR CLIMBING BIRDS.

(143.) WE now enter upon the Scansomar, ORDER, comprising all those families whosc feet are more particularly organised for climbing trees; and whose different modifications of structure have been already so fully explainerl. * These nembers, - excepting in the gemus which unites the Scansores with the Rasores, - are particularly short, for they are never used to walk upon the ground. With the exception of one family, the whole lave the toes placed in pairs, - that is, there are two beforc and two behind, - a peculiarity which renders them of easy determination, notwithstanding the many and striking variations in the form of the bill and wings. The whole of these birds are naturally arranged in the following primary divisions of subfamilies:- 1 . The Certuads, or creepers ; - 2. 'Ihe P'icin 2 , or woodpeckers ; - 3. The Psitracid 2 , or parrots; - 4. The Rampiastid 2 , or toucans; - and, lastly, the Cuculidx, or cuckows. These families, collectively, form a complete circle ; the

" Vol. I. p. 153.

VoL. 11 .

Ii 
junction of the last with the first being effected by the great hollow-billed genus Phrenicophreus, and by Sythrops, the Australian genus of toucans. If we consider the woodpeckers as the most perfect of all climbers, they will constitute the typical group; for, although the parrots possess the grcatest intelligence and the most varied organisation, they do not excel in that particular quality which constitntes the perfection of the scansorial structure: wc must, therefore, consider them as the representatives of the Dentirostres, and of the hawks, - an analogy fully borne out by the structure of their bill: these two, therefore, form the typical and the subtypical groups of the entire circle. The great lead and large size of the toucans, independent of their often catching their food in the air, plainly indicate the fissirostral type. The cuckows, which are the most imperfect climbers, are therefore the most aberrant; while the Certhiadce, or creepers, represent the scansorial division, as already intimated. We shall now take a hasty glance at cach of thesc families, the minor groups of which will be systematically defined in the subsequent synopsis.

(144.) The Centurads, or creepers, of all other climbcrs, evince the closest affinity to the suctorial orker of Tenuirostres, like them they are generally of a small size; like them, they have a very slender, delicate bill; and in both groups the hind toe is nuch developed. Some of the honeysuckers, as the Entomiza cyanotis $S$. *, climb trees; and the similarity of Clymusteris mysticalis to a Meliphage is so great, that no less an ornithologist than M. 'T'emminck has actually mistaken it for such. Nothing, therefore, can be more conclusive, if authority were alone to decide the question, than that the Scansores pass into the Tenuirostres by means of the Certhiade in one, and the Meliphugide in the other.

(145.) The primary divisions or subfamilies of the Certhiadre, did our space arlmit of their full elucidation,

* Lewin's Birds of New Holland, pl. 4. 
afford one of the most ample proofs that could be adduced in favour of those principles of the natural system for which we eontend. In our systematic arrangement the several groups will be so arranged, and we can only, in this place, glance at a few general features of the whole group. Nearly all the typical species are confined to that contiment of forests, Tropical America; but the common English creeper (Certhiu familiaris 1.) will give the student a very good idea of their general structure. The nuthatch, with its long pointed wings, shows us the fissirostral type; while the true wren of our own climate exhibits that form which is the most aberrant. With the exception of these three generic types, and of Tichodroma, confined to the South of Europe, the remainder, eighteen, are exotic ; thirteen of which are exchusively confined to Tropical America. In this number we exclude the following genera, introduced among the Certhiadre by some authors, because, upon analysis, we find they belong to other groups, in which they merely represent the crecpers:-1. Upupa, as being the scansorial type of Promerops;-2. Orthotomus, as being the same in the eircle of the typical warblers (Sylvianc); - and, 3. Mrotiotila, from holding the same analogical station among the $\Lambda$ merican Sylvicolex.

(146.) The Centurans arrange themselves, with the above deductions, into the following subfanilies:1. The Anabntince, or redtails, where the tail, although somewhat rigid, is never acute, and the two outer toes are not urited; -2. The Certhiane, or typical creepers, having the tail ending in sharp and often horny points; both groups, with one exception, being confined to 'Tropical America; - 3. 'The Buphugine, or ox-peckers, where the bill is sliort, thick, and the tail like the first division;-4. 'The Troglodytine, or wrens, having longer and more sleuder bills and toes; - and, 5. The Sittince, or nuthatches, where the toes are enornously developed for the size of the body, and the bill straight and somewhat wedged-shaped; thus opening a passage to the typical woodpeckers. 
(147.) The true wrens (Troglodytes) have such a slight developement of the scansorial powers, that ornithologists have very generally placed these little birds with the goldcrests, or true warblers. The analysis, however, subsequently given of this last family, leaves no doubt in our mind, that their natural situation is in the present group. A very singular part of the economy of our common wren has not, we believe, been made known. If attentively observed, it will be seen that, on flying into a hedge or thicket, it almost invariably enters that part nearest the ground, and energes towards the top; if watched within sucl retreats, its progress is always upwards ; and al though it hops, rather than climbs, still the elongation of the hind toe is evidently intended to assist its progressive ascent, slight, indeed, but continued. Again, it is perfectly clear, that wherever the American wrens (Thriothorus Vieil.) are placed in a natural arrangement, ours must follow; for a separation so forcel, would, in our opinion, be sufficient of itself to shake the very foundations of any system in which the two groups were widely separated. Lastly, it will appear, upon analysis, that the true wrens are actually represented anong the warblers, by a genus (Prinia) hitherto stationed among the climbing creepers. In this rapid sketch of the animal kingdom, we are compelled to pass over details; but we must occasionally notice such as these, not only to give the reader a sufficieut insight into our own views, but to explain upon what grounds we venture to question the correctness of all those eminent naturalists who have gone before us.

(14S.) The structure of the PICIN $\mathrm{s}$, or woolpeckers, constitute them the nost perfect of all the climbing birds, for nature has rendered their whole organisation subservient to this particular power. The feet, altlough very short, are unusually strong; the mails are broad and crooked, and the toes placed in pairs, - that is, two forward and two backward. As an additional and a powerful support to these birds in their rapid and perpendicular ascent up the trunks of trees, their tail- 
feathers terminate in points, and are uncommonly hard; so that this member, being pressed against the bark, is a furtler help to the bird in his perpendicular attitude. The bill, no longer slender, is now destined to be einployed in the laborious operation of penetrating hard wool, or of stripping off the bark of forest trees, and is accordingly arlapted in the most beautiful manner for such a purpose; it is perfectly wedge-shaped, furnished with regular-sided angles, and in one species (Picus principalis) is nearly the colour and consistency of polished ivory; hence it has received the name of the ivory-billed woodpecker: the tongue has also a peculiar formation; it is worm-like, barbed at its point, like the head of an Indian spear, and is capable of heing thrown out to a great length: by this mechanism the bird can introduec it into holes and crevices, or even under the loose bark of old trees, infected by those peculiar insects which it is the province of the woodpeckers to destroy. As wature advances progressively to this perfection, so does she recede from it: some of these peculiarities are lost, and others very much diminished, in all the remaining climbers we shall presently notice.

(149.) The divisions of this family arc strongly marked; beeause, as some few intervelling forms are wanting, the circle is, in one sense, incomplete. Thus the nuthatches (Sitta), although clearly approximating to the woodpeckers, are not directly united to them: neither does the intervention of the wryneck, with its long wormlike tongue, or of Oxyhrynchus, with its acute bill, do morc than indeate the broken links of the chain. The absolute connection between the trute woodpeckers (Piciuna) and the subfamily of barbuts (Buccoinn) is unquestionably established by two very singular little birds, -one being the minute woodpecker of Linneus (Asthenurus Swains.), the other a barbut (Picummus Tem.). But before proceeding further, let us pause a while on the genuine woodpeckers, as their aatural arrangement amony themselves deserves partiI. 3 
cular attention; we only regret that our confined limits prevent us from giving more than an abstract of their internal relations.

(150.) The true woodpeckers (Piciane Swains.) are typically represented by the great ivory-bitted speeies already noticed. Here the upper and the lower ridge of the bill exactly correspond in their inclination towards the tip, rendering the bill a perfeetly straight wedge. This constructiou is rendered still more perfect by a ridge, forming a strongly earinated line, which runs parallel to the eulmen, and is situated nearly half way between that and the external margin of the upper mandible. The crests of these birds are very short, rigid, and turned upwards: but their chief distinction, as a genus, rests on the structure of the feet, the hinder external toe being inanifestly longer than that in front: this peculiarity is even extendel to such aberrant species as lave one of the small toes wanting, as the two northern species, Apternus trilactylus and arcticus. To this group, therefore, we restriet the generic name of Picus, and it includes all the British species excepting viridis. In the next group, Chrysoptilus, we find a diminution of these typical excellences; the bill, as in our common green woodpeeker, is still nearly straight, but the lateral ridge, before alluded to, is placed elose to the culmen, and the lind toe is either of equal length or slightly shorter than the fore toe: the crest, although still short, is less rigid, and not so inuch developed. The colours of these birds are always gay; green, and not black, predominates; and most of the typical speeies have the quills of a beautiful golden hue, $-a$ cireunstance which suggests the generic name of Chrysoptilus. The third is a highly elegant genus: the bill is now no longer straight; the culmen, or upper ridge, being evidently more arehed than the lower ridge, or gonys; and this latter is particularly short, owing to the prolonged advaneement of the chin, which accupies full one half of the under mandible. The lateral ridge of the upper mandible is as in the last 
genus; but the anterior toe is now become obviously longer than the hind toe: the crest is long, formed of loose feathers, and, like the rest of the plumage, is particularly soft; hence we have denominated the genus Malacolophus. The fourth genus we long ago named Colaptes, and as this lias been generally adopted by ornithologists, we nced only here observe, that it is distinguished from the last by the greater curvature and compression of the bill, and by the disappearance of the ridge on the upper mandible; thus assimilating the group to the Tenuirostres, and exhibiting the weakest structure among the whole of the woodpeckers. The fifth and last genus (Melanerpes) may not unaptly be called swallow woolpeckers, for they resemble those birds in their migratory habits, their long wings, and their black glossy plumagc, destitute, in the typical examples, of spots or bands: yet here we find nature has began to return once more to her original type: the ridge on tlic bill is again apparent, at first but slightly, but finally very distinct; this member, likewise, although not straight, is less arched than in Colaptes; the two greater toes are of equal length; the wings long and pointed, and the third quill equal or longer thair the fourtlı; the black and white plumage, seen only in the typical genus Pieus, is again assumed, until the two groups are blended together by such birds as Pions rubriventris Vieil., P. varius L. \&c.; so that the circle of the true woodpeckers is rendered more complete, perhaps, than any other in the whole class of birds. The primary divisions thus appear to be three: the first having the bill equally angulated, and the linder toe longest; the second, with the angles unequal, and the two longest toes of the sanc length; the third has the culmen curved, the angle obsolete or wanting, and the hinder toe shortest. Very many of the subgenera of these five principal forms have been determined, and their chief characters will be found in our systematic arrangement.

(151.) To the Buecoince, or barbuts, forming the second K 4 
principal group of the woodpecker family, we are conducted by the minute woolpeeker (Asthenumus minutus Sw.), whose blaek and spotted head indicates an affinity to Malacolophus. M. Temminck, having diseovered a small barbut whieh is closely related to this type, has thought it expedient, without any assigned reason, to rejeet our name, and substitute a new one of his own. The barbuts liave the same constructed feet, and possess the same property of clinbing, as the woodpeckers, but in a muelı less desrree : their tail featlıers are soft, and of the ordinary construction : the bill, in some, is vely strong, straight, and compressed; in others it is greatly depressed; and in one group, short and toothed. Mr. Burehell was the first naturalist who discovered the affinity of these singular birds to the woodpeckers; having repeatedly heard their loud tapping in the forests of Southeru $\Lambda$ frica, and witnessed their dexterity in climbing trees: in the straight-billed or typical barbuts (Bucco), we liave the predominant colours of the parrots-green, red, blue, and yellow variously combined; while the black and red plumage of the tooth-billed division (which is the true type of the whole) corresponds with that of the most perfectly formed woodpeckers: a third group, whose precise station is not yet known, represents these birds in South Ameriea.

(152.) The other genera whose elimbing labits have induced naturalists to place thein with this family, are I unx and Oxyrhynchus. The first of these types belongs exclusively to the Old World ; and two species have been discovered: the latter seems to be the representative of it in America, and is at present confined to a single species.

(153.) The Parrots eonstitute the subtypieal division of this tribe, wherein the powers of climbiug are less developed. If any group in nature be isolated, it is this. Possessing in themselves the strongest characteristics, there is no bird yet diseovered which presents any point of connection to thein: approximations, indeed, are certainly made towards them by the tooth-billed barbuts 
(Pogonias); but therc is still a gap, which no genus yet discovercd is calculated to fill up. On considering the relative difference between the barbuts and the parrots, we should say, theoretically, that of all the five groups among the latter, one only remains to give us the typical structure. The form, manners, and pecularities of thesc elegant birds are too well known to be here repeated. They climb by grasping; and the feet possess the additional faculty of eonveying food to the mouth, - a peeuliarity confined to these and to the goatsuekers. As the parrots appear to form a group preeisely equivalent to that of the true woodpeckers, we arrange them, with a uniformity of result, under five genera, namely, the maeaws (I'lntycercus Vieil.), the parrots (Psittacus L.), the eoekatoos (I'lyctolophus Vieil.), the lories (Lmius Bris.), and the ground lories (Platycercus, Vig.). Under each of these, as among the woodpeckers, are several strongly marked subgenera, or types of form; but we are reluetantly compelled to take no further notice of them, in this work, than what will be found in the systematic arrangement.

(154.) "The fourth family is represented by the Toucans, whose enormous bills give to these birts a most singular ancl unconth appearance: their fect are formed, like thosc of the parrots, morc for grasping than for elimbing; - the latter faeulty they do not, indeed, appear to possess ; but as they always live amoug trees, and proeeed by hopping from branch to braneh, their grasping feet are peeuliarly adapted for suel habits. Toueans arc mostly large sized birds, distributed over the New World, slender and graceful in their movements, and ornamentud by rich and glossy colours. The apparent disproportion of the bill is one of the innumcrable instances of that beautiful adaptation of structure to use, whieh the book of nature every where reveals. The food of these birds principally consists of the eggs and young of others; to discover which, nature has given them the most exquisite powers of smell: these organs could not be developed under the ordinary form; the bill, therefore, is made so 
large as to contain an infinity of nerres, disposed like net-work, all of which lead immediately to the nostrils, and are protected externally by a thin horny covering; so that the bill, apparently so heavy, is in reality uncommonly light, and is no inconvenience to the bird whatever. The interval between the toucans and the parrots is not, perhaps, so great as between the latter and the woodpeckers; still it is sufficiently wide to make us believe that one, if not two, of the intervening types are wanting. The genera we restrict to four; Ramphastos, Pteroylosizes, and Aulacorynchus, being found in South America, while Sythrops is their representative in Australia.

(155.) The fiftl and last family is composed of the Cuckows, - a mumerous and diversified race, which is spread over all the temperatc regions of the globe. Their principal distinction rests on the very short and slencler make of tleir feet; formed, indeed, much on the same model as those of the toucans, yet with one of the back toes so versatile that it can bc occasionally brought forwarl, - a structure which we have already illustrated ; while the habits of our European cuckow, which is a typical example of the whole, are known to almost evcry one. The majority of the true cuckows build no nests : thcy fiy rapidly, and lave the nostrils perfectly round: others, of the American genus Coccyzus, have short wings, and live almost entirely on small insects gleaned from the slender branches of lofty trees. The diversity of form observed in this family, renders it highly probable that all the genera of the two typical divisions are known, although the others have not yet been sufficiently studied. The following observations arc, thercfore, intended merely to show the apparent connection of this with the other scansorial families.

(156.) The passage from the toucans to the euckows, seems to be marked by sucl genera as Phaniropharus or Saurothera, where the bill, as in the first, is cither much larger and thicker than in the generality of cuckows, and is thus assimilated in shape to that of the toucan, or, as in Saurothera, where the edges become dentated. Crotophaga 
appears to come between these and Cocсyะus; while the latter are closely.connected with the true cuckows by the two North American spccies forming our subgenus Erythrophry:* The ground cuckows (Ccntropus) do not materially differ from the above, except by the remarkable length of their hind claw, which is similar to that of a lark. The ncarest approach we yet know of to the creepers, is made by the African honeyguides, whose bill is not unlike Orthonyx; and these birds are sail to climb in a more perpendicular manner than any others of this family: the affinity, indeed, of Indicator to $B u$ jhaga has already beet pointed out $\uparrow$, and it seems to us too strong to be questioned; an inspection of their bills alone (fig. 157.) will sufficicntly indicate their affinity.

(157.) The union of the scansorial tribe with the rasorial order of birds may now claim our attention; becruse, as the Cuculida are tlie most aberrant family of the first, it consequently follows, that among the most aberrant forms of this family we must look for the nearest approach to the rasorial structure. Rasorial birds have many peculiar characters : their size is generally very large; their bill compressed; their feet strong ; and their wings short, convex, and rounded. Now, there are two or three very large cuckows, possessing all these characters; yet, from having the toes arranged in pairs, would seem to enter within the confines of this family, although at its ntmost limits. The Cocey:us Gcoffroyi of Temminck ( $P$ \% Col. 7.), as well as the C. Delalandi of the same work (1'l. Col. f. 140.), are clearly of this description, and nothing woukl induce us to place them among the cuckows but the particular disposition of their toes. Not, however, having the immediate opportunity of examining these two rare birds, (the only specimcns which we have seen are in Paris, we shall bring forward another discovercd in Mexico by Mr. Bullock, and which is now, or lately was, in the possession of the Zoological Society : This bird, which we consider

- Magazine of Botany and Zool. I.

+ Vol. I. 1. 14t.

t The reason 1 have heard against throwing open the museum of the zoological society to the free use of naturalists, is, that rules and regu. 


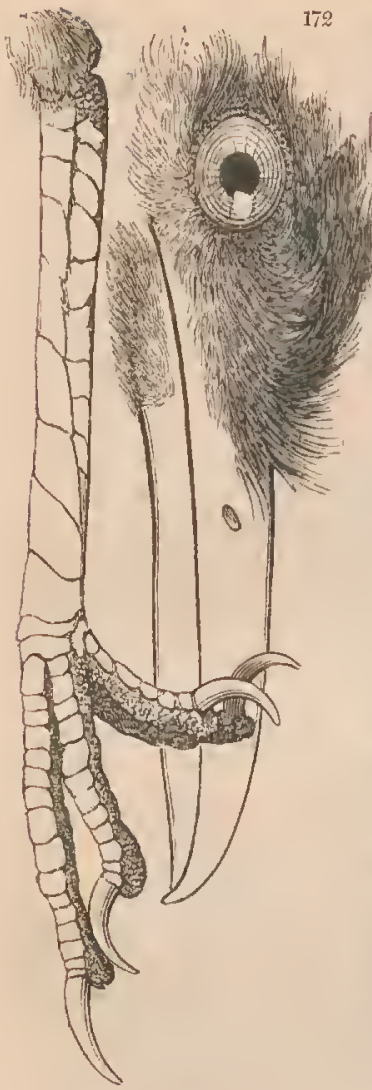

as the grallatorial type of the Cuculide, forms our genus Leptostoma; and it is highly probable, although their bills are shorter, that the two species above quoted will likewise belong to the same group. The lead and feet, here represented of the natural size ( $f i g$. 172.), are completely those of a rasorial bird excepting the toes, which indicate that link by which it is unitel to the cuckows. A more perfect union, indeed, of the two circles of the Seansores and the Rasores could scarcely be imagined; for, were the toes not placed in pairs, Leptostoma would, to all intents and purposes, be a rasorial genus. 'The wings are uncominonly short; and its legs, for a cuckow, very long: it thus preserves its analogy to Centropues, which is also a grallatorial type.

(158.) The union of the three great tribes of

lations, special permissions, se, are necessary to "prevent evalition," or rather clashing, among naturaliat, artists, \&c. The fallayy of this reason. ing is best shown in the cage before 45. Loing before the bird in question came into the possession of the Zoulogieal Socjety, I carefully examined, and named it in the catalogue of the Mexican Museum : the results, however, I have never, until now, published; and yet this very specimen has remained in the Sacicty's museum neur len years, without any published account of it (as tar as $\mathcal{L}$ can learn) appearing, although it is cortainly the 
perching birds into a circle of their own, has already becn intimated. Every writer, since the days of Linnæus (who at first actually classed them in the same genus), has placed the motmots (Prionites) and the toucans (Ramphastos) close together, not only from the similarity of thcir habits, but from the structure of the tongue, which in both is long, and so much ciliated at its sides as to rescmblo a feather ; so far, therefore, the resemblance is unquestionable. But the feet of the motmot are totally different from the touean; they are not scansorial, but of that particular structure so common among the Fissirostres. 'I'he toucans we know, from personal observation, to be gregarious, living in flocks, and seeking their food from the tops of lofty trees; the motmot is solitary, hiding in the deep shades of the forests, and, like other airfeeding birds, is always found sitting ncarly motionless. Here, then, is a very ohvious departurc from the structure and habits of the toucan. The question, then, is, to what does it lead? If to the hornbills (which has been inferred from the structure of the fect), we should have no diminution in the size of the bill; which, in both the hornbills and toucans is equally large, but in the motmot of an ordinary and proportionate size: we should further expect a bird which was gregarious, since both these groups arc so. Yet there is nothing in the motmot, beyond its fect, whieh will at all assimilate it to the perchers; while its fissirostral habit of catching its food upon the wing, and the discovery of the broad-billed species, Prionites platyrhynchus*, seem to us a conclusive argument for placing this genus in the fissirostral order, as more intinately related to the jacamars ( $G a l-$ bula) than to any other known genus.

most extraordinary type yet discovered in this family. So far from any "coalition" being apurehended, it thus appears that the Society might well be grateful to those who will take the trouble of making known their unexamined stores. Although I have the drawing of the details of this hird betore me, I have lost its descriftion, so that this litter enn mly be supplied by an athorised mewber of the Zoological Socisty. Can this be the Saurothera Culfornica of Lesson, "Traite d"Orn. $\mathrm{l}$. 146.? or are there two or more species?

* Linn. Tr. vi. 92. 


\section{CHAP. X.}

ON THE TRIHE OF TENUIROSTRES, OR SUCTORIAL BIRDS.

(159.) Tue most aberrant division of the insessorial order is that of the Tenurostres, or honeysuckers; so called from the great majority deriving their subsistence both from insects and the neetar of plants, which they suck up by means of a long or filamentous tongue, particularly adapted for that purpose. As these birds are furthest removed from the types of their order, they consequeutly show a greater affinity to the Scansores on one hand, and to the Fixsirostres on the other, than to the more perfect groups of the perchers, as seen in the Dentirostres and the Conirostres: like the scansorial creepers, the bill is slender, and the feet very short; but there the eomparison ceases. The seansorial birds clerive their food entirely from inseets ; and, in general, have a simple and pointed tongue: but those we are now to eonsider, are chiefly supported by vegetable juices, extracted by means of a very long tongue, always retractile, and either simply forked, or clivided into so many slender filaments as to resemble a painter's brush; the bill, moreover, is so soft or delicate, that it is often incapable of grasping food, and appears, in the typieal groups, prineipally intended to proteet the tongue, as the chief member by whieh life is supporter.

(160.) The families of this tribe will be briefly notieed under three heads : - First, the humming birds (Trochilince), which possess all the above characters in the greatest perfeetion; secondly, the sunbirds (Cinnyride), where the feet are more lengthened; and, thirdly, such families as either have the tongue short, the fect very strong, or the bill notehed: these three divisions, which form the aberrant group, are the hoopoe birds (Promeropida), the Paradise birds (Puradisida), and the honeysuckers (Meliphagida). 
(161.) The hoopoes (Promeropid $\approx$ ) betray so close a resemblance to the bee-eaters, that there can be no reasonable doubt of their absolute affinity. The species are few in number, and are all restricted to the Old World : one alonc, the common hoopoe (Upupa Epops L.), annually visits Europe, in company with the bee-eaters, rollers, and other swallow-like birds; but, unlike its congeners, it seeks its foorl upon the ground. The bill in this family is equally long with that of the bee-eaters, frequently, indeed, much longer; like them, also, the tongue and the feet are very short, and the toes, in both, are syndactyle. The plumage of the hoopoes is generally glossed with a metallic blue and deep green; and, in one species, the side and tail feathers are developed in the most singular and extraordinary manner: this is the grand Promerops of New Guinea, - a bixd of such excessive rarity, that only two perfect specinens are known to exist in Europe. It inhabits the same regions as the Paradise birds; and, from analogy, it may be thought to unite that beautiful family with the hoopoes. The only skins of these sumptuous birds which reach Europe, are generally deprived of the legs by the savages who prepare them for sale; and, until the structure of the feet is better known, it will be impossible to determine the precise station which this bird occupies.

(162.) 'The station we lave assigned to the PanadiSIDE, or Paradise birds, has heen before intimated. * They are among the largest of the Tenuirostres; and seem to live, like all their representatives, on soft substances, and these appear to be chicfly fruits. The best known are those species so commonly used as ornaments for the head; and in these the bill is rather strong, and somewhat conic: but whell we turn to others, and obscrve, the long and nearly falcate bills of the twelve-wired Paradise bird - of M. Cuvier's Epimachus - of our genus Ptiloris, and then compare the slender bills of Paradisea magnifica, sexsetacea,

* Northern Zoology, it. 
and regia, with those of the neighbouring group of honeysuckers (Mteliphage), the resemblance is sufficiently strong to believe it is one of affinity. On the other hand, it must be remembered that the genus Paradisea of Liunean ornithologists, and of inost subsequent writers, is an artificial group, formed of those birds whose plumage is the most extraordinary or magnificerit, without sufficient regarl to other parts of their structure. Thus, the Paradiva aurea was most judicionsly considered by Linnsus a true oriole, while the Puradisea gularis proves to belong to the starlings (Stumida). The diffieulties attending a knowleilge of these superb creations are, indeed, very great. Restricted to a few sinall and remote islands of the Indian Ocean, whose inhabitants are almost cannibals, these splendid skins only reach us through the Chinese traders, mutilated, and dried upon sticks. All writers, it is true, have plaeed the Paradise birds in the same order with the erows: but this argument, taken by itself, is of little value; since there is an evident connection between the hoopoes and the Paradise birds, and again with these latter and the rifle-bird of New Holland (Ptiloris paradiseus, Sw.): the whole aspect, indeed, of this latter gemus is that of a long-billed Paradise bird; while its legs, which are very short, are of that peculiar structure which belongs to the family we shall now enter upon.

(163.) The Meliphaginle, or honeysuckers, are distinguished from all the preceding fumilies by their notchel bill; the tongue is also terminated by a bunch of delicate filaments; and the hind toe is so strong and robust, that it serves as a powerful support to the bird during the process of feeding: on this partieular structure we have already offerel more detailed observations.* It is sufficient here to mention, that, from this kiul of tongue having been confounded witl the eiliated form seen in the orioles and other birds, several errors have arisell. Some of the natural groups,

* Zool. Journ, vol, i. p. 480. 
however, have been pointed out by Messrs. Horsfield and Vigors*, but, from a deficiency of analysis, their combinations do not appear to be natural: the attempt, however, deserves much praise ; for it is advisable, at all times, to point out prominent distinctions in the first instance, before we venture on tracing the flam ariadncem of nature. As our own views of the natural arrangement of the Meliphagida will be seen in another part of the volume, we slall here only take a rapid view of such groups as we include in this family. The typical genera are sinall or middle sized birds; but some of those which are aberrant grow much larger. In the genus Philedon Cuv., the head is nearly bare of feathers, and the ncck is surrounded with a ruff somewlat similar to that of the vultures; their size is nearly equal to that of the jay; the claws are strong and acute; and, as these birls are said to chase others of a smali si\%, one would almost imagine they represented the rapacious order. In what appears to be the rasorial form of the typical genus, we have the wattles of a gallinaccous bird; while the Etourneaux verdatre of the $\mathrm{P}$ 'aris Museun seems to be a true honeysucker, disguised as a starling. 'These and many other most curious analogies are only so many indications that the Meliphagidce contain types of every order and tribe throughout ornithology ; while the existence of such a singular form as plitoriw paradiseus, already adverterl to, leads to the suspicion that the family may be truly connected with the hoopoes, so as to unite the aberrant divisions of the whole tribe into one circular group. Having now slightly touched upon the three aberrant fanilies of the Tenuirostres, we may proceed to those more typical, in which the claracteristic distinetions are fully developed.

(164.) The subtypical family is composed of the Cimmyride, or sunbirds, so called by the natives of Asia in allusion to their splendid and shining plumage: between this family and the last the affiuity is obvious;

$$
\text { * Linn. Trans. sv. } 311 .
$$

VOL, II. 
but whether the direet passage is made by the shortbilled honeysuckers (Diceum Cuv.), or by the spidersuckers (Avuchnothera Teu.), is uncertain. The plumage of the meliphagous birls of New Holland is almost univorsally dull, or at least destitute of those gay and beautiful tints which are so strikingly developed in the sumbirds: a rich golden green, varied ou the under parts with steel-blue, purple, bright orange, or vivid erimson, decorates nearly all the speeies, and produees a brilliancy of eolours only rivalled by those of the humming.birds. 'The bill is very long, slender, and acutely pointed, the margins being dentated in the most regular and delieate manner; yct thesc teeth are so small as searcely to be seen by the naked eye: the tongue is formed into a bifid tube, or rather, as we suspeet, into two flattened filanents; thus differing materially from that of the honeysuckers, whieh always ends in a brush: the bill also is never notched. The difference between the two struetures is softened down by the intervention of the nectar-birds (Nectarinia 1ll.), whose bill shows a union of both charaeters, - the margins being fincly dentated, and the tip distinetly notched. The species of the latter are few ; and while Cinnyris is restrieted to the tropies of the Old World, Nectarinia represents them in the New. Some few other forms, found in Australia and in the Oceanic Islancls, belong to this group, and they are arranged in the genera Melithreptes and Diceum, but their habits are imperfeetly understood.

(165.) In the Trосншылs, or humming-birds, we have the full developement of the suetorial perfeetion belonging to this tribe. The bill, from its soft and delicate strueture, appears adapted for no other purpose than to protect a long bifid and flattened tongue*, darted by these little ereatures into the nectary of flowers, for the purpose of lieking the honey: but, like the rest of this tribe, the humming-birds are partly insectivorous; a

* The tongue of the humming-birds has always been described as tubu. car; but in all that I have examined, the two tilaments are perfecily that. 
faet we have personally ascertained, having repeatedly discovererl minute flies in the stomachs of those we dissected. In speaking of these charming birds, the naturalist is almost tempted to abandon that didaetic style best suited to his subjeet, and to elothe his informlation in the language of poetry; yet botl must fail in conveying to the mind an adequate idea of their surpassing beauty. The rainbow colours of the most resplendent gems are here superadded to a living form, which in itself is exquisitely graceful and animated in all its movements : the flight of these pignny birds is so rapid as to elude the eyc; for a few moments they may be secn hovering over a flower, but so soon as they have sipped its sweetness they vanish in an instant; thcy may, in truth, be said to "come like shadows, so lepart."

(166.) Between the humning-birds and the last genus there is obviously a strong affinity, although we are unacquainted with the precise link which connects the two. The old autliors not unfrequently confounded the two raecs; but they are too distinet to be mistaken even by a modern student. The Cinnyride have full-sized legs, and their wings moderate and rounded: the hummingbirds, on the contrary, have the feet excessively short and remarkably small; while the wings, for the size of their body, are frequently longer than those of the swallows. As the sunbirds are restricted, to the tropical latitudes of Africa and India, so are the hummingbirds confined to America; both groups are rieh in species; and of this, in partieular, the variety of seeondary forms is almost innumerable. IVe have endeavoured to determine the five principal genera, but the subgenera can only be eorrectly ascertainerl by a much more rigid analysis than we lave yet been able to make. In the genus Trorhilus, as now restricterl, we have all those whose bills are perfeetly straight, the tail bcing either even or slightly divaricated. Cynanthus comprchends such species as have the bill slightly bent, with a tail very long, and deeply forked. If we look to the sunbirds on the one hand, and to the hoopoes on

$$
\text { เ } 2
$$


the other, we immediately perceive that the straightness of the bill is a typical perfection of the humming-birds. In the gemus Lampornis the bill is obviously much depressed at the base, and the tail is broad and even; while the type of the genus Campylopterus seems to be the recurved-billed humming-birds. Last of all comes the genus Phothornis: hitherto the form of the tail has either been square, forked, or rounded; but in this group the tail is considerably and regularly graduated, the side feathers very short, and the middle pair far exceeding all the others; the bill is not nerely bent, but so much eurver in the typical species as nearly to assume the form of a sickle. The gay and beautiful green which ornanents the inper plumage of all the groups here gives place to a brown colour, and even the throats of the male birds are destitute of ornament. The genus Phothornis, in fact, obviously represents the rasorial type, and is a miniature likeness of the hoopoes, or to that family with which we began our survey of the Temuirostres.

(167.) Although the circle of this tribe is by no means so complete as some others, it must still be remembered that nothing yet known tends to invalidate the suceession of the forms here traced. On looking to the hoopoes, and niore particularly to the gemis Epimachus of M. Cuvier, we sce an evident tendency in nature towards some extraordinary developement of plunage, quite different from the usual arrangement; nor in no one family is this more apparent than anong the Paradisinde. On looking again to the genus Ptiloris; we have such a elose resemblance botli to the Eyimachus and to the Paradise birds, that some writers have actually placed it as spreeies of Epimachus; and such it would unquestionably be, but Tor its possessing the feet of the Meliphagide. It is quite immaterial to this view of the subject, whether a whole or a part of the Paradise birds enter between the Promeropida and the Meliplungide: it is sufticient toshow thestrong probability of the in terval being filled up bysome bircts of a sinilar construction, - that is, 
partaking both of the structure of the hoopoes and of the honeysuckers; and both Cuvier, Lesson, Jardine, Selby, and James Wilson concur in believing that our Ptiloris paradiseus cxhibits such a union: into which of these families, therefore, Ptiloris naturally enters, is a secondary question, which neel not licre bediscussed. Theoretically we might make use of this form, either to pass from the Paradise birls to the Meliphagida, or to connect the latter with the Promeropidce, and thereby represent the aberiant circle as closed. T'he views, indeed, of the ornithologists above naned, are all in favour of the latter supposition, seeing that they have not, in every instance, separated Ptiloris from Ejpimachus; the latter being universally considered as a hoopoe. Such appears, to us, an impartial statement of the difficulties which at present impede our knowledge of these three groups.

(168.) Between the honeysuckers and the sunbirds the affinity is unquestionahle; and no one can doubt that the lattcr are followed by the humuning-birds. The similarity between these latter and some of the small hoopoes is sufficiently strong to point out an affunity not very distant between them, so that there is every reason to believe the Tenuirostres are naturally disposed in one great circle. 'The Trochilida', nevertheless, are one of those strongly marked groups in nature, which, if the term can be correctly applied, are, in one respect, isolated. The species are very numerous, and exhibit among themselves a great variation in the structure of particular mombers; yet, when viewed $a s$ a whole, they are stanped with such a peculiar character as to be recognised at the first glance. In other groups, ormithologists are perpetually referring species to families which thcy closely resemble, but to which they have 110 real affinity: yet no one can mistake a humning-bird, a horubill, a toncan, a parrot, or a falcon; nor is there hardly any speeies in these gronps partaking so little of their respective typical charicters, as to excite a doubt to which it truly belonged. Now, in applying these remarks to I. 3 
the humming-birds, we have already shown that they form among themselves a circular group; it consequently follows that the gencra by which they are conuccterl with the hoopoes must, if in existence, belong to the Promeropida, - a family wherein the species and forms are few, and where there is a sufficient interval to admit of two or three intermediate gencra, the discovery of which would at once fill up the hiatus between Promerops and Phothornis. Having alrcady offered several remarks on the relations of this tribe*, when compared to other ornithological circles, tre may now at once pass on to the last of the principal groups in the order.

\section{CHAP. XI.}

ON THE TRIBE OF FISSIROSTRES, OR SWALLOW-LIKE BIRDS.

(169.) Tne order of Frssimostres is best represented by the swallows and goatsuckers: the former are the most isolated; while the latter, above all other birds, show the nearest affinity to the owls. No species, indeed, has yet been discovered, which would perplex a naturalist to decide to which of these families it belonged: but that is not material: we do not uphold the injudicious theory that every one of nature's links are so perfect, or rather, are so well known, as to leave no unequal intervals in the series; on the contrary, we maintain that such interruptions are frequently found, and, in this manncr, are the goatsuckers detached by a slight interval from the owls.

(170.) The fissirostral birds, as a whole, arc peculiarly distinguished, by having the powers of flight developed in the highcst degrec: all the cnergies of their nature seen concentrated in this one perfection; 
for their feet are always very short, weak, and generally so imperfeet as to be of no farther use than to rest the body after flight: their foor is exclusively inseets, captured upon the wing. To accomplish this, nature has given to their mouth an enormous width, by which, superadded to their amazing flight, and rapidity of movement, they are almost sure to eapture their prey. Who, that has watched the swallow or the goatsucker, has failed to recognise these peculiar perfections? As the noeturual goatsuckers frequently prey upon beetles and large moths, the mouth, in such species, is defended by stiff bristles: but these appendages are rendered unnecessary to the swallows; their gane consisting entircly of those little soft insects seen in the air on a summer's evening, or sporting on the Howers of a sunny field. 'The goatsuckers ehoose the twilight, and eatch their food preeisely in the same way, excepting, indeed, that their little short feet are sometimes used for the same purpose, - a nost singular part of their economy, first noticed by our countryman, White. Some of these noeturnal birds (1'ognrdus Cuv.) have a bill nearly as strong as an owl; others are furnished with forked tails of excessive length; and one species, discovered during our researches in Brazil (Caprimulgus diurnus Tem.), (juits the nocturnal habits of its congeners, and in cloudy days may be scen in troops of fifteen or twenty, skinming over the surface of ponds, precisely in the manner of swallows: these two groups, in fact, are connected by certain swifts; for the Balassian swift * is described as "a nocturual bird, appearing at sunset, and going to rest at sunrise."

(171.) We thus enter the family of swallows (Hirundinide), which present many singular variations of structure anong themselves: in the true swifts (Cypselus), the hind toe is so placed that it ean be brought nearly forward, and all four are armed with very strong crooked claws, giving to the bird such a firm grasp, that it can sustain itself by the side of

* Gen. Itist, of Birds, vii. p. 399.

I 4 
perpendicular rocks or buildings with the greatest facility: others (Chotura Stev.), with less robust feet, are compensated for the deficieney by being furnished with a very stiff and pointed tail, which serves as an additional support, when resting in such situations. In the long-winged swifts of India (Macropteryx Swains.), all these characters are modified, and we see the swifts clianged almost into the swallows. The two typical groups of the Fissirostres are thus united, and both may be cliaracterised by a very sliort bill. The third group, as usual, contains threc others, all exhibiting, more or less, a similar economy, but having the bill considerably more lengthenet.

(172.) The Meropida, or bee-eaters, succeed the swallows. This family is confined to the wann regions of the Old World: one species, however, the Merops apiaster, or European bee-cater, has occasionally strayed to Britain. These birds annually visit Italy in flocks of twenty or thirty, and may be seel skimming over the vineyards and olive plantations with a Hight much resembling the swallow, though inore direct and less rapid: their bill, however, is considerably longer and more gracile; but this difference is softenterl down by the intervention of the genus Eurystomus, containing the swallow rollers of India, Africa, and Australia, where this nember is very short. To these succed the true rollers (Comeins Lin.), which arrive in Italy at the sane time with the bec-eaters, and associate also in small flocks. These two genera of rollers are so indissolubly mited, that nothing but the strongest prejudice in favour of a preconceived theory could ever liave induced certain naturalists (whose labours, in other respects, have been of inuch advantage to science) to have placed them in two rlifterent orders. The whole structure of the rollers, their lengthened pointed wings, and their firm and often forked tail, at once induces the idea that they feed upon the wing; while their very short legrs, scarcely longer thau their hind toe, might lave slown their ineapacity to alight and walk, like the crows, upon the ground: 
but this question is at once decided by a knowledge of their economy, which, from personal observation, we have every reason to believe is much like that of the bee-eaters. The intervention of the yollers at once lessens the abrupt transition, which would otherwise be apparent, from the perfect-footed swallows to the zygodactyle beeeaters; and we are thus prepared for all those birds, whose toes, as it were, are soldered togethor like those of the Meropidre. Here, perhaps, we may notice that most beautiful and rare genus, Nyctionnis, or night-feeder *, as being, in all probability, tliat particular link by which llature connects this family with the trogons, - tlereby uniting the three aberrant groups of the Fissirostres in to one primary eircle. M.'Temminck, overlooking its peculiar structure, placed this genus with Merops, to which, indeed, it has a close resemblance ; while its connection to Prionites (111.) in other parts of its organisation is no less obvious. Its precise situation, in short, requires further investigation.

(173.) The family of Haleyonidre, or kingfishers, is obviously connected to the last. It eomprises several well marked genera, agreeing among themselves in the great lengtl of their bill, and in the extreme shortness of their feet. 'These characters, it is true, belong also to the true bee-eatcr; but here a remarkable difference in economy is first developed. We have seen that the goatsuckers, swallows, and hee-eaters traverse the air to search after and pursue their prey; their wings are, consequently, adapted for long and continuet flight : but the family now before us have a different economy, and therefore a different organisation. The whole of the gewera are scdentary, watching for their food from a fixed station, which they only quit as soon as their prey approaches sufficiently near to come within the sweep of their wings: if unsuccessful in their first attack, they do not pursue threir gane, but return again to their post, and patiently wait for another luekless straggler ; if their first attack is successful, they return with their vietim

* Zooj. Lunst. ii. 11. 56i, 
to the same station, and then proceed to swallow it. Every one knows that these are the habits of the European kingfisher (Alcedo ispida) and travellers affirm that the kinglunters (IIalcyon) pursue the same method in the forests of the Old World. But it has unfortunately happened that systematic naturalists, totally unacquainted with the natural labits of the other genera (nearly all of which are confined to Tropical Ameriea), have fancied they were climbing bircls, and have consequently placed them in other orders, whose organisation and economy are widely differeut. Thus the jacamars, in the $R$ ène Animal, are placed after the hornbills, and the puffbirds (Tamatia) areassociated with the cuckows. These unnatural combinations are the inevitable result of laying dowu tlose arbitrary rules of elassification which are not founded on natural econoiny.

(174.) The manners of the puff-birds, forming the genus Tamatia, lave been already deseribed.* They sit for hours together on a dead or withered branch, from which they dart upon such insects as come sufficiently near. 'The hermit birds (Monassa Vieil.) do the same, and frequently rise up perpendicularly in the air, make a swoop, and return again to their formerstation. Similar manuers also, belong to the jacamars, although their flight is weaker. They generally sit on low, naked branches in the forest paths, from whenee they dart upon butterflies, speariug them with tleir long bill : their haunts, indeed, may frequently be known by the ground being strewed with the beautiful wings of their victins, the body of which they alone devour. Now, in all the groups of this family here noticed, the bill is invariably connpressed on its sides, and generally of considerable length ; but in the Gulbula grandis we first discover a change from this structure, and we sce a bill considerably broad and depressed, - that eharacter, in short, which is in unison with the ncxt family.

(175.) The Trogonida, or trogons, in one sense, are sueh an isolated group, that naturalists have been much 
perplexed in what natural family to arrange them. M. Cuvier, in placing them near to the puff-birds (Tamatia), seems to have had some perccption of what we bclieve to be their true station in naturc, although hoth these groups find a place among his climbing birds (Grimpeurs). M. Temminck arlopts the same views. Mr. Vigors, in his "Natural Arrangement," first placell the genus Trogon between that of Crotophaga and Corythaix, with a mark of doubt, but subsequently he located the trogons near the parrots. The trogons are abundant in South America; and are, perhaps, onc of the most extraordinary genera found in that continent. They are not climbing birds, nor are they in the least organised for that jurpose: they live in the deepest and most gloomy shades during day, wherc they sit, almost motionless, on a dead branch: during the morning and cvering they are more active; at these times they go in to the open partsof the forest, and, taking a shady station, dart upon winged insects, particularly hart-coated beetles; at othcr times they feed upon fruits, especially on the rich purple berries of the different Melustome, "which they invariably dart, mofcisely the winue us if they were insects capable of getting away! The singular account of these birds given by our hunters first awakened our attention to them in their native regions, and these results have since been fully confirmed by the ohservations made on those species pcculiar to Demerara by $\mathrm{Mr}$. $\mathrm{W}$ aterton, a well known and observing field naturalist. Finally, the trogons, like the goatsuckers, have remarkably thin skins; like them, they fecd upon the wing; the fect of both are so short and feeble, as searccly to be of any other use than to rest the the body; the bill in both is remarkably short; the plumage in both is soft and loose; both have the mouth defended by strong bristles; and both are most active during twilight. Here, therl, is the point, if not of absolute junction, at least of the strongest affinity yet discovered, between the Cnprimulgide and the Troyonida: and it is thus, as we conccive, that the circle of the Fisurirostres is formed. We began with the goat- 
suckers; and, after tracing their connection with the swallows, the swallows with the bec-eaters, and the bee-eaters with the kingfishers, we finally return to the point whence we started.

(176.) The other genera associated with the trogons deserve attention : we have already mentioned the peculiar broad bill of the great jacumar. Between this bird and the trogrons are placed the different species of motmots (Prionites Ill.); one of which has the bill greatly depressed, and all, like the genuine trogons, have the margins toothed or serrated. l'laced, therefore, at the extremity of this family, the motmots appoar to conncet the trogons with the jacamars, while at the same time they effect that important union witl the scansorial birds whicl we have already mentioned.

(177.) The analogies lxtween the forcgoing families and the principal divisions or tribes of the perching birds have already been mentioned. 1t nevcrtlieless becomes a question, whether the Caprimulgide should not be considered as typical of the Fissirostres, rather than that station should be assigned to the Mirumdinida, upon the same principle as that which makes the Picidce, and not the Prittacida, the chief type of the Scansmes. The Caprimulgides and the Picidae are each pre-eminent in that particular organisation which belongs to thcir own circles, just as the Irirumlinide? and the P'sittacide have the greatest general perfection of structure in all other respects. If, then, the anlogics are to be thus founded, the families of the Fissirostres, and the tribes of the Insessores, will each follow in their true chain of affinities, without that transportation seen in the table, Vol. I. p. 360. - thus :

$\left.\begin{array}{l}\text { Conirostres. } \\ \text { Dentirostres. }\end{array}\right\}$ The two typical groups.

Fissirostres. Pursue their prey on the wing.

Tinuirostres. Bill very long, slender, entire.
SCaprimulgitac.

\{ Hirundindate.

Meropida.

Halcyonidae.

Scansores.: $\left\{\begin{array}{c}\text { Wings short, convex; till short, arched } ; \\ \text { tail broad, long. }\end{array}\right\}$ Trogonidee. 


\section{CHAP. XII.}

ON THE RASORIAL ORDER, OR GALKINACEOUS BIRDS.

(178.) Trie gallinaceous birds, or Rasores, may be generally characterisel as large, heavy, and terrestrial; and as being that order more especially sct apart by their Great Crcator for the service of man. IJence they are more easily domesticated than any other birds, their flcsh is the most savory, and their fccundity the most productive. They exhibit in the highest perfection all thase characters which we have elsewhere assigned to one of the primary types of nature, which among bircls is called the rasorial, and among quadrupeds the hovfed. Strong thick legs, long necks, slort wings, elegant crests, and large ample tails, characterise the majority of these birls; and they arc the only ones, as a group, which, like the ruminating quadrupeds, habitually eat the green leaves of vegetables. 'They live, indeed, almost entircly upon the gronunl, which consequently affords then their chief nourishment in the seeds and grains of different plants. The domcsticated races of the fowl, the turkey, and the pcacock are familiar to cvery one, and in themselves give us the typical habits of nearly the whole order. Here also we rank the pigeon tribe; since, although it exhibits many peculiarities, nore especially that of rapid flight, it is still in many other respects inseparably a part of this orler. The Rasores are the largest birds in creation; for among them are found the ostrich, the cassowary, and the emu: they arc also the most gentle, and are endowed with thic greatest aptitude for domestication; since, above all others, they administer to the wants and the comforts of man. Thcir flesh and their eggs are universally wholesome and very nutritious; while their featlers are employed, 
both by the philosopher and the savage, in giving comfort and rest to the human frame. As conmected with the gentleness and inoffensive liabits of this tribe, we find a peculiar developement of the love for their offspring: and that the increase of the domesticated species should keep pace with the wants of man, we remark a fecundity inuch greater than in ordinary birds. The more scientific distinetions of the rasorial order, in comparison with that of the perchers, may be thus briefly stated :-Their external peculiarities are very striking: the feet are particularly robust, and the hind toe, being placed on a greater clevation than the fore toes, almost debars the foot from any power of grasping; the hind toe, indeed, is either frequeutly minute, or altogether wanting: the bill is short and strong, having a peculiar horny appearance; it is destitute also of a noteh: the wings are muscular; but the quill feathers are short, unusually convex, and much rounded: many of the typical groups have the tarsi armed with spurs, as in the domestic cock; while such as show the typical characters in their full perfection, have the tail feathers of an extraordinary length, and magniticently coloured. Their internal organisation is equally peculiar: like ruminating quadrupcds, they have three stomachs; the sternum is markcd by two deep lohes or notches, the anterior part of the crest of which is truncated, so that the sharp end of the furca is joined to the sternum by a mere liganent; this conformation, by werkening the peetoral muscles, at once acconnts for their inferior nowers of Hight.

(179.) The Lalits and econony of rasorial birds are well exemplified in our domestic races. They are social, live in societies, and are polygamous. They prefor escaping from danger by running, and only take to flight when compelled by necessity. 'The females are generally the smallest, and always the least oruamented: they are fond of rolling in dust, to free themselves, as it is thought, from verınin: some nestle on the ground, and live only on plains; while others, of 
the more aberrant divisions, as the guans and pigeons, reside in forests and nestle in trees.

(180.) The analogy of the rasorial birds to the ruminating quadrupeds lias been so fully investigated in the preceding volumes of this series, that we shall now merely bring before the ornithologist the results of our analysis of the two groups. Independent of their general analogies, which they exhibit as a whole, it appears from the following table, that even the primary divisions of each possess separate analogies, readily understood by those who are acquainted with the two classes.

Analogies of the Rasorian Biros with the Ungulated or Hoored Quaniurens.

$\begin{array}{ccc}\text { Primary Families of the Autogical } & \text { Families of the } \\ \text { Circles. } & \text { Rasores. } & \text { Characters. }\end{array}$

Typical. Pavonidis. Tail excessively long. Soltrides.

Subtypical. Tetraonidis. Tail very short. Ruminantes.

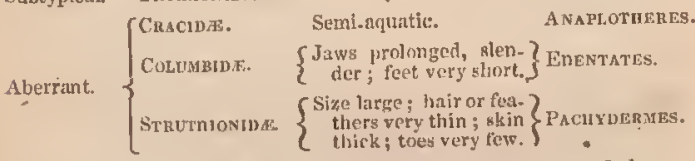

(181.) The preacock, as the pre-eminent type of the rasorial structure, has the longest and most clegant tail of any bird in creation; and this is precisely the distinction of the horse among quadrupeds, of which it is the preeminent rasorial type. 'The most beautiful crests are found among the rasorial hirds; while the hoofed quadrupeds are those only which have erests in the shape of horns. It is well known that the ruminating order is emineutly herbivorous; and the Rasores, in a state of nature, are the only birds which eat grass. The types of both orders live entircly upon the ground, for only part of the Rusores roost upon low trees. Both are the most gregarious of their respective classes, not ill one or two instances only, but with scarcely any exceptions. The Ungulata have the fewest toes of any quadrupeds; and this, in regard to birds, is a grand characteristic of the Rasores, where we have the family of ostriches actually 
representing - as seen in the above table - the gigantic elephants, and the other Pachydermes. But let us look further into the secondary analogies expressed in this table. The Soliperles, or liorses, and the Pavonide, or pencocks, are already disposed of ; while, in the types of the Ruminantes (as the deer and antelopes), and of the partridges (Tetraonida), the shortness of the tail is one of their great peculiarities. The Struthionide or ostriches, still more beautifully represent the Puchydermes in their great bulk ; while the obtuse horny protuberance of the cassowary is a most striking representation of the short horn of the rhinoceros. The pigeons (Cohumbidre) in one order, and the Edentutes in the other, follow next; let us, therefore, see how far these groups are analogons. The Edentutes, or anteaters, are remarkable among the loofed quarlrupeds for having the greatest prolongation of muzzlc, and in having the shortest feet: the muzzle of birds is their bill; and the bills of the Columbidre, or pigeons, are the longest and the most slender, consiclering the size of the birds, of any anong the Rasores ; while their feet possess the opposite extreme of shortness: each, again, are the most abcrrant in their respective circles. M. Cuvier is decidedly of opinion that the extinct Awhplotheres, like the modern tapirs, lived in the vicinity of water or in marshes, aud that they thus became semi-aquatic. Such are the localities of the American Cracile, or curassow birds, as we know from personal observation; while their long and somewhat rigid tail preserves that affinity to the Scarsores which has been alrealy mentioned.

(182.) The precise manner in whieh this orler is connected to that of the perehers, through the merlium of the Stansores, has been variously stater. M. Cuvier considers that the Musophagida, or plantaineaters, approxinate oll one hand to the Sinnsores, and on the other to the Gallinarea; and this opinion has been so strongly taken up by others, that not even a doubt has been expressed on the subject. We have, however, already tracel the affinity between the plantain-eaters, the plantain-cutters, the finches, aud 
the hornbills. Nor are there wanting other reasons, equally strong, against this popular theory. When we eall to mind that gregarious habits, and a constant partiality for the ground, are two of the most universal peeuliaritics of the liasores, it appears very little likely that the plantain-eaters formed the connecting group between these two orders. The genera Musophaga and Corythaix are described by those who have seen them in their native haunts, as solitary; and Le Vaillant expressly states, that the beautiful green touraceo of the Cape (C. persa) perehes only at the extremities of the highest branehes of trees, beyond gunshot. Here, then, we trace not the most distant resemblance, in manner or eeonomy, between two genera, which have been supposed to connect the elimbing with the gallinaeeous birds. Let us look, therefore, among the cuckows for some genera which show this affinity more elosely. Crotophuga, for instaner, resembles the Rusores: both liave sueh a weak flight, that they seldom proceet far on the wing; both habitually live, and build their nests, upon the ground; and both associate in flocks. Among hundreds of the common $A n i$, which we have seen in South $\Lambda$ merica, we never beheld one perch upon any thing higher than a bush; and this was but seldom, as they are habitually terrestrial birds, tutally differing in eeonomy and habits from the European or the Ameriean cuekows. Their seansorial feet is no serious objection to their affinity with the Rasores ; for, if the authority of Linnatus is to be trusted, there is aetually one which has three toes before and one behind. But if we wish a eloser affinity, we may look to the genus Leptostoma, already mentioned (157.), where the long legs, short convex wings, entirc bill, and large size of the body, remind us immediately of a rasorial bird: but this affinity seems carried even still further by the Coccysus Geoffroyi' 'T'em., - a bird represented* with a long and robust foot, nearly twiee the length of all the other known species,

$$
\text { * Pl. col. } 7 .
$$


having the whole aspect of a $C r a x$ or a Penelope. We again allude to thesc approximatinns of the cuckows to the Rasores, to sliow that the former are much nearer to the latter than is Musophagu, whose affinity with the Comirostress seems to us, at least, indisputable.

(183.) The natural divisions of the Rasores, and their circular arrangements, have hitherto received but little attention, nor have we yet been able to analyse more than a few of their minor divisions; we sliall, therefore, merely refer the systematic reader to the technical definitions of the genera, which we have arranged in what appear to be the natural families: these succeed each other in the following order:1. The Cracide, or alectors; 2. The Pavonide, containing the peacocks and the fowls ; 3 . The Tetraonide, or partridges ; 4. The Siruthionida, or ostriches; 5 . The Columbide, or pigeons.

(184.) The large American gallinaceous birds, forming the family of $\mathrm{C}_{\mathrm{r}} \mathrm{AcID}$, are chietly distinguished by all their toes being placed on the same plane or level, like those of the perching order* : their legs, also, are destitute of such spurs as we see upon the feet of the common cock; and the tarsus, in proportion to the size of the bird, is short and slender: the hind toe is mucli developer; we accordingly find that these birds frequent and perch upon trees, nearly as much as upon the ground. In their plain colours, they offer a singular contrast to the brilliant plumage of the Asiatic races, which occur in nearly the same parallels of latitude in the Old World. It is singular that so little pains have litherto been taken to domesticate these American fowls; since, by their sociability and gentleness, they evince every disposition to live under the dominion of man. 'The flesh, as we know from personal experiment, is particularly delicious.

(185.) The genera need only be briefly glanced at. The first we place upon the list is Penncopr (Mer.) (fig. 173.), known by the inore familiar name of guans. In 
the long graduated tail, compression of the bill, and length of the hind toe, we see an evident approximation to several of the euckows. There are many speeies, mostly of a dull colour; yet some have white crests, and nearly all are bare of feathers round the cyes and throat; the skin on the latter being capable, as it is said, of iuflation. Their windpipes are singularly twisted. In Ortalida, the head is entirely plumed. Close to these birds, some systematists have plaeed the rare genus Opisthocomus, hitherto found only in the swamps of Guiana. M. Souniui informs us, that it feeds on the berrics of the Arum arborescens; which, being a large trec, eorroborates the singular faet he states, that these birds seldom go on the ground, but remain tranquilly perehed upon those branehes which hand over the water, the greatest portion of the day. It deserves, also, particular attention, that the toes, unlike those of all other gallinaceous birds, are totally destitute of a basal membrane. We have never been fortunate enough to see a living speeimen of this rare bird, the only one of its genus, - and ean, therefore, offer no opinion on the degree of affiuity it bears to the scansorial tribe ; or, according to M. Temminek, to the erows! The cireumstances in its history leat us to suspect the former affinity must be the true one. Is the outer toe in any degree obliquely inserted? The most beautiful examples of this family are seen in the erown or curas. sow birds (Crax L., fig. 174.). 'Their lieads are adorned with short elcvated crests of curled feathers, which assume the appearance of ending in little globules. giving a majestie appearanee to the bird, whose gait is slow and majestic. Formerly, as M. Temminck reeords, these birds were very common in the menageries of Holland, where they became equally tame as the 


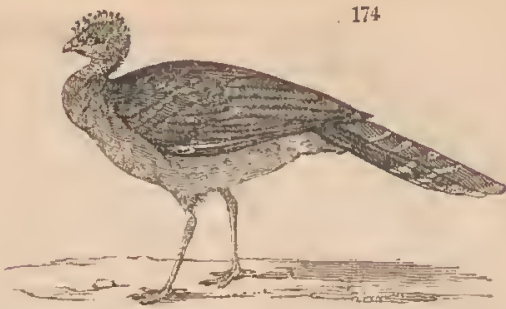

fowl, the turkey and the peacock; yet the greatest care and attention were necessary to induce them to breed aud rear their young. It seems, however, that this was done so completely by M. Arneshoff, that several species in his menageric were as prolific as common fowls, and even gave an ubandant supply for his table. In Brazil, and, indeed, in all parts of their native country, their domestication is totally disregarderl. Close to these we may place the genus Oumx Cuv., or cushews, chiefly distmguished by a shorter and nuch thicker bill,-a peculiarity which learls us to suspect this group represents that of the hornbills (Bucerus L.): three or four species, all natives of the Brazilian forests, have been describel by modern writers. There are two other genera which have

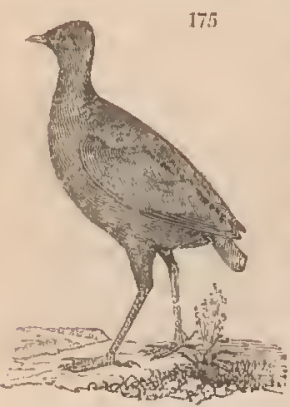
recently bcen placed in this family*, with which they certainly accord more than with any other group of the Gallinacea: these are Menura and Megupodius (fig. 175.); the first represented by the magnificent lyretail of New Holland, the latter by two species from the adjacent islands : both have the feet unconimonly large, and both seem to represent the scansorial genus Ortlony $x$, - a birl, indeed, ecarcely larger than a sparrow, but agreeing in the very 
remarkable scansorial character of having the three fore toes of nearly the same size. If the Cranide, as we believe, is the scansorial family of the Rasores, this singular analogy is precisely what we should expect in two grouns representing the same tribes. The habits of the two last-named genera have never been made known. Our leamed friend, chief justiee Field of Gibraltar, long a resident in New IIolland, assures us that Menura, in all its habits, is a gallinaeeous bird; living on the ground in small societies, and very fond of rolling in the dust.

(186.) The l's $\Delta$ vorid $\&$, containing the peacoek and pheasant, as M.Cuvier well remarks, follow the great Gallinucea of America, noticed in the last fanily. In this group have been assembled also the different species of eocks, scattered so profusely over the hotter latitudes of Asia. IVe now have the typical characters of the whole order displayed in the eonspicuous shortness of the hind toc, the formidable spurs on the legs, and the most beautiful developement of the tail. 'The whole of the genera belonging to this division, with the exception of the turkey, are natives of the warm latitudes of the Old World.

(187.) Among the genera, we shall first notice that of Meleagris, comprising the domestic turkey, and another, still more beautiful, inhabiting the forests of Honduras. This latter (the Meleagris ocellata Cuv.) has the tail feathers onmented with eyelike spots, something in the manner of the Oriental peacocks, which it seems to represent in the New World. On the magnifieence of our domestic peacock, standling at the head of the genus $P(L v o$, we need not dwcll ; we cau eonceive nothing nore grand, at least, to the eye of an ornithologist, than to coutenplate, unobserved, a flock of these gorgeous birds in their native forests: they appear to be comunou in most parts of Ilinclostan, and are considered by the English hunters as birds of game. China and Japan produce other species, scarcely less brilliant, but very little known in Europe. The Argus peacock or plreasant forms the genus Polyplectron, 
(Tem.). It is strikingly distinguished from the last, by the peculiar form of its tail, and by having several spurs to the feet. Destitute of the vivid and shining colours of the true peacocks, this birl is perhaps equally beautiful, being covered almost entirely with dark rings or eyelike spots upon a cinnamon coloured ground. Of the genus Argus Tem., little is known beyond its being a very shy and delicately constructed bird. In that of Gallus is comprised the different species and varieties of our domestic fowl; since it is now generally admitted that these have originated from races perfectly distinct. M. Temminck, who las investigated this subject with great ability, conceives that our common poultry have descended from the Gallus giganteus and the Gullus Bankiva: the first a very large species, inhabiting Sumatra; the otler much smaller and common in Java. The genns Lophophorus, likewise Indian, comprehends the famous Impeyan pheasant of Lathan,, whose plumage can only be compared to the most refulgent hues of variously coloured polished metals. We are next led to the beautiful group of pheasants; one of which, - the conimon species of our preserves, - is well knowu : like all its congeners, its native country is towards $\Lambda$ sia ; and, however beantiful, it can scarcely be compared with several othcrs, natives of China, Japan, and the elcvated mountains of Thibet. Africa furnishes us with only one genus in the Guineafowl (Numida L.), flocks of which occur in the swainps of Western Africa, and represcnt, in those pestilential regions, the turkey of the New Workd.

(188.) The TETranonin form the third family, composed of the partridges, grouse, and quails; all of which birds agree in the extreme shortness of their tails, and of their hind toe: they arc also remarkable for a total want of that brilliancy of plumage which so eminently characterises the last family. The genus Cryptony $x$ has been thought to connect the two,-a supposition by no means improbable, yet requiring analogical proof. It is a sinall group of Oriental birds, highly beautiful from 
the elegant form and texture of their crests: three or four species have recently been described. Following these we may notice the grouse: those of the colder latitudes constitute the genus Tetrao, while Pteroeles includes such as inhabit the arid sands of Africa and Southern Europe. The northern parts of our empire still furnish us with several species; but the largest and

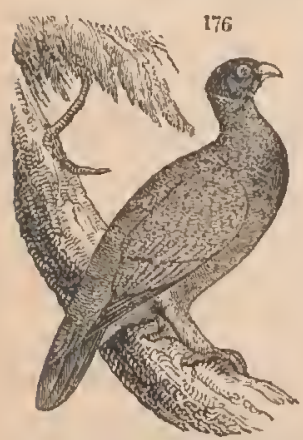
most noble grouse of Europe, the cock of the rock (fig. 176.), has long bcell cxterminated in Britain. Sornetimes the side fcathers on tlic neck of the male birds are developed in a singular manner, so as to rescmble little wings, - a character mostly confined to two American species (Tet. umbellus and Cupido). Several new and imposing additions to this group were brought home by the arctic navigators under Capt. Franklin. The African and Indian grouse (Pterocles) have frequently very pointed tails, and the hind toe is very small: heat, with them, appears to be as essential as cold is to the true grouse. But there is one species ( $P$. setarius Ten.) which extends its range to the South of France. Nearly all the grouse have the toes and legs more or less covered with soft feathers; but this character disappears in the partridges, - an extensive group scattered in nearly all parts of the Old World, but unknown in the New, where they are represented by the genus Odontophorus Vieil. In the quails (Coturnix), we have the miniature resemblance of partridges, but the tail is so short as to be nearly imperceptible. Closely approaching to the true quails, we have the genus Hemipodius, distinguisherl by the total absence of the hind toe: the disposition of these little birds is so extremely pugnacious, that quail-fighting is as great an arnusement to the Javanese and other Indian nations, 
as cock-fighting formerly was to the Europeans. There is, in Tropical America, a very singular race of birds, called Tiunamous by some of the Brazilians, and Ynambus by Azara (Cryptumus Ill.): they have scarcely any tail, their body is thick, and their whole appearance reminds us of a pigmy bustard ; which group they probably represent in the New IVorld. The species are numerous : as for their Hesh, we have often tasted it; and consider it, both in whiteness and flavour, infinitely above that of the partridge or pheasant. IVe believe these birls never perch, as some suppose, but that they live entirely among herbage, principally in the more open tracks of the interior.

(189.) The STruturovinz, forming the fourth family, is composed of the largest birds in creation; namely, the ostrich, the cassowary, and the emu; emiuently distinguished by their size, their imbecility of flight, and by never having more than three toes to their feet. Nature has given them but the rudiments of wings, yet she has amply compensated for this deficiency by the gift of most extraordinary speed in running. We find these birds are distributed with a beautiful regarrl to geographic order: Rhen is the American ostrich, Struthio the African, Casuarius the Asiatic, Dromiceius the Australian, and Otis the European. From this family we entirely exclurle the dodo, which was, in our opinion, the rasorial type of the Vulturidre.

(190.) The Corumbide, or pigeons, form our last division. These elegant and lovely birds are placed by M. Cuvier at the end of the Gallinecea, - a station which is supported by many weighty considerations. The pigeons appear as much isoluted from all other birds as the parrots; for, although the fanily is particularly numerous, and spreal over cvery part of the world, there does not appear one spccies, yet discovered, which cxcites a doubt as to its true affinities. Distinct as they appcar, when viewed as a whole, we find they present many remarkable variations among themselves: these form different subordinate groups, to which generic names, by 
common consent, have been now applied. The fruiteating pigeons of Africa and India, forming the genus Vinago, are easily known by their very thick, hard, and strong bill, which is also much coinpressed : thcir feet are short, and the toes broad, and formed for clasping: they are said to live entirely on fruits, and to frequent the deepest forests: all the species are from India and Africa. The next group, forming our genus Ptilonopus, is, without exception, the most beautiful of the whole family. The ground colour of the plumage is generally of a deep rich green, frequently very glossy; while the head and wings are generally variegated with blue, white, purple \&c. These belong also to the hot latitudes of the Old World; although they seem, upon the whole, more abundant in the Indian and Australian islands. In inany respects, particularly by their feathered feet, these lovely birds resemble the last; but their bill is much more sleuder, and thus marks the transition to the ordinary pigeons, still classed in the genus Columba, and of which the wild and domestic species of Britain are good cxamples. The passenger pigeons of Anerica offer some slight variation from the European ; but not sufficient, perhaps, to detach them as a genus. The turtle doves (Peristera Sw.) are a smaller group in stature, and lead us immediately to the ground doves of 'Tropical America (Chumepelia $\mathrm{Sw}$.$) : these little birts live in socicties, avoid$ woods, scarcely ever perch upon trees, but are constantly seen upon the ground, like true Gallinacea. The remaining forms of this family are very superficially understood: we can only pcrceive they all tend towards the true rasorial structure; and by their longer legs, crests, wattles, \&c., show a decided tendency to unite the family with some other: the most remarkable of these is the crest-crowned pigeon lien (P'tilophyrus Sw.), and the most beautiful is the Nicobar pigeon.

(191.) A few observations on the affinities of the gallinaceous fanily will conclude our survcy of this order. In the rapid sketch here given, we have judged it expedient to omit all speculations on the precise 
manner in which the primary groups pass into each other: such assertions, when not founded upon complete analysis, cau only be received as merc opinions: wc shall therefore merely offer a few remarks on the analogy of the pigcons to the Grallatores, in further proof of the station given to this family in our arrangement of the Rasores.

(192.) On looking to the three aberrant groups of the Rasores, in reference 'to the primary orders of birds, the ostriches (Struthionida) evidently reprcsent the Natatores, by their broad, depressed, and somewhat duckshaped bill_-by their imperfect toes - by their great sizeand, lastly, by the wings being as unserviceable for flight as are those of the penguin. Here, then, we have a certain point from whence to start; and the question becomes reduced to the narrower compass of which family, in short, represents the Grallatores and the Tenuirostres. These groups, it will be remembered, are remarkable for their soft and slender bills; so also are the pigeons: the nostrils are large, long, and covered by a thin soft inembrane: the pigeons are the only Gallinacea which answer to this description; they have the most slenter bills, and their nostrils are long, large, and soft. Grallatorial birds have great strength and power of wing: the huunming. birds, - a grallatorial type, - fly swifter than swallows: and pigeons are the only rasorial birds which possess this power to any extent; for it is "well known their flight, in general, is vcry rapid. The waling orker is particularly remarkable for being destitute of crests, - one of the most distinguisling characters of the Scansures and the Rasores: so also are the pigcons one species only out of near 150 being furnished with this appendagc; this being a rasorial type in its own circle. Finally, we have a singular analogy preserved between the cuckows and the pigeons, by the rump feathers being of that peculiar formation which belongs to the orioles, the caterpillar-catchers, and several other temuirostral types scattered among the perchers. With these strong relations before us, we feel no doubt 
whatever that the Columbida represent the Tenuirostres: it therefore results that the Cracide will typify the Scansores; with which, as before mentioned, they evince a disposition to unite by absolute affinity: the Pavonida thus become the typical family, and the Tetraonide the suhtypical.

\section{CHAP. XIII.}

ON THE ORDER OF GRALLATORES, OR WADLNG BIRDS.

(193.) In taking leave of the rasorial order, we finally quit all those familics which are usually termed land birds, and enter among such as habitually frequent the water; but nature, ever prone to follow those "measured steps and slow," by which all her changes are accomplished, places between those great divisions, inhabiting two different elements, a peculiar order, whose habits partake both of the one and of the other. This order is composed of the Graliatoris, or waders. It comprises all such families as live both on the land and sca, and to whom the one elcment is as cssential as the other. There food chiefly consists of small marinc animals, cast up, or inhabiting the shorc. To procure such food, these birds must often wade in the water, or traverse marshes : hence they are provided with remarkably long legs for elevating their body, and slender bills for penetrating into the soft ground. Such as are more espccially aquatic have a short wcb to their toes; while others, like the plovers, which seldom venture into the water, have not this structure. Their wings are very long; for they have no scttled district, but fly from shore to shore as the seasous change. Incapable of that perfection in swimming which is developed in the next order, the waders may be termed mariuc Rasores, or fowls of the 
sea : they are always walking on its shores, or on the sides of fresh waters; and they depend as much upon thcir ambulations for seeking sustenance, as upon their wings for those long expeditions they are known to inake. Their external structure varies considerably, particularly in regard to the number and disposition of their toes : the bill is generally long, and in the typical groups very slender ; the upper mandible is entire; the wings pointed, and the tail invariably very short, the legs bcing used as a rudder during flight.

(194.) The families under which we consider the waders to be naturally arranged, are these:-1. The Andeand, or lierons; - 2. The Charadrinas, or plovers; -3 . The Turvern a, or sandpipers;-4. The RALilin, or rails; - 5. The TaNTaLina, or ibices. These seem, therefore, to follow the order in which we have placed the primary types of the animal kingdom: the second and the third are the typical groups, distin. guished by having the hind toe either altogether wanting, or very short and elevated; while the three others, forming the aberrant division, have the hind toc of the usual proportionate length, and placed on the same level with the others. Without attempting, in such a sketch as this, to point out the aftinities by which these families may be connected, much less to expatiate upon the union of the different genera which have been arranged under each, we shall merely add a few illustrations of their characters and habits to the scientific details subsequently given.

(195.) The ARDEADs, or lierons, by means of the cranes, show the strongest affinity to the ostriches, and thus unite the rasorial witl the wading order. Nearly all the cranes are large birds, with short and powerless wings; long, and frequently naked, necks; and more terrestrial in their labits than any of their congeners. The beautiful genus Phosphia, if truly belonging to this fa-. mily, is more of a gallinaceous than a wading birl ; since it lives in the forests of South Anerica, and is said to be sometimes domesticated for the purpose of guarding 
poultry-yards : its note is very singular, and has given rise to its popular name of trumpeter: only two speeies are known, in size somewhat larger than a domestie fowl. The majestie elegance of the demoiselle eranes (Anthropoides Vieil.) is well known, from their frequency in our menageries: the head is generally bare of feathers, and ornamented by a singular lateral crest. We were the first, we belicve, who deteeted this genus in Europe; specimens of the Arden Paronina $\mathbf{L}$. having been brought to us, when in Malta, from the little island of Lampidosa, where they are by no means searee. The more typical cranes (Grus Pall.) are large birds, few, indeed, in species, but dispersed over liurope, Ameriea, and Asia: they secm to prefer the seelusion and the security of marshes, and feed both upon seeds, licrbage, worms, and small reptiles. The Ardeade, or typical herons, differ from the last in being eomposed of birds deeidedly carnivorous: they are known by a larger and more pointed bill, and by the superior length of the legs. Of this subfanily we have more than one indigenous speeies. The herons, as a whole, are the most bcautiful of all the wallers, not so much from the colours of their plumage, as from the elegant crests and prolonged feathers which ornament nearly all the speeies. They build in societies, but generally feed and live solitary. Like the kingfishers and many of the fissirostral birck, the greater part wateh for their prey from a fixed station: a sheltered nook by the side of a river, or a projeeting roek by the sea-side, over deep water, frequently serves them as a convenient post; here they watch for passing fish, which they dexterously spear or transfix by their long and sharp bill. Some of these birds are of a gigantie size; others are very small; but a lave all very long neck, covered more or less by long and loose feathers. The tiger bitterns ( Tigrisoma $\mathrm{Sw}$.) are exclusively found in South America, but the true bitterns seem restricted to no partieular elimate. The boat-bills (Cancroma L.) differ most essentially from the herons, since they have a short and very broad bill, shaped something like a boat 
with its keel uppermost. Some authors enumerate three, and others only one species; but they are all peculiar to the New World. The spoon-bills (Platalea) show a different, but a no less singular, form of beak, from which their name has been derived. The storks ( $C_{i-}$ conia I.) are amoug the largest of the heron fanily; one species (Ciconia gigantea) measuring, when standing ercet, ncar five fect and a half: they are social and useful birds; and from destroying vast numbers of reptiles and other vermin, are encouraged, in many countrics, to build on the habitations of man: the chin and eyes are bare of feathers; but in Mycteria, which possibly enters into this family, the greatest part of the liead and neck is entirely bare: one species inliabits America, one Asia, and one Australia. The tufterl umbre forms the African genus Scopus, and is the only species known; the plumagc is particularly soft, and tlie back of the head furnished with a lax tnft of feathers: this is obviously allied to the open-bills (Anastomus III.), a singular form, remarkable for a thick and very powerful bill, gaping in the middle. It is impossible to divine for what purpose this structure, altogether unique among birls, is intended to perform, since their economy has never been explained. These are the principal genera whicl appcar to enter into this family, of whieh the herons and cranes form the two most typical groups.

(196.) The Cinananians, or plovers, as already intimated, form the subtypical family of this order. It seems connected to the Ardeadce through the inedium of the cranes ; the thick-knces, Fidicnemus; or, probably, by the genus Cariama of Latlian,-a form we have never minutely examincl. In this comprchensive group, the feet are long and slender, formed for great speed; the toes are sliort, and the hinder one is gencrally wanting; the wings are long, and consequently the powers of Higlit are very great. Herons and rails seek the inost secluded recesses of marshy shades. Plovers and sandpipers, on the contrary, live only on sandy and unsheltered sliores, or on exposed commons; they congregate in floeks, and 
run with great swiftness; their heads are thick, and their eyes large, dark, and placed far back in the head; the bill is short, with the basal half soft, but the outer half becomes abruptly thick, and is often obsoletely notched, so as closcly to resemble that of the pigcon family, which, in the rasorial circle, appears to represent the great order of waders.

(197.) The following genera are the most prominent types:- The oyster-catchers are rather large and strong birds, marked with black and white; and their principal food is supposed to be oysters and other shellfish. One species alone belongs to Europe, the others are natives of South Ameriea and Austratia. The turnstone (Strepsilus) is at once recognised by a short stout bill, rather turned upwards: the name is derived from the labit it possesses of turning up stones on the sea-shore, to feed upon the marine insects concealerl beneath. The couriers (Tachydromus 11l.), although confined to the old World, scem to be very widely distributed: one species oceasionally visits Europe, and has twice been shot in England; the others, four or five in number, come from the African deserts and the sandy districts of India; they are closely united to the Pratincoles, or swallow-plovers, forming the genus Glareola. These latter have their wings very long, their bills short, and their tails generally forked; they are small birds, and fly with great celerity. Our beautiful lapwing forms a typical example of the subgenus Vunellus. The true plovers (Charadrias) form a numcrous group, very elegantly although not richly coloured, and dispersed, with little or no variation of form, over the whole world. The feet, as in the spur-winged plovers, are only thrce-toed, and the wings are much pointel; sometimes there is a slight membrane between the outer and the middle toe, but this is usually wanting. We have two elegant little species on the liritish coast, and some others occur in Southern Europc. The longshanks (Himantopus) have been placed in this group, but we believe thcybelong to the Tringide: whatever their true statiou may be, 
they are eertainly some of the most singular birds in the family; and, by the excessive length of their legs, they no doubt represent the flamingos: we know but of three species. At the eut, or rather at the eommencement, of this group, we may place the thick-kneel bustards (Adienemus); sinee they are obviously allied to the Charadriadse, or plovers, on one side, and to the Ardeadce, by means of the aberrant eranes, on the other. All the species have been hitherto confined to the Old Wortd; butanother, described in this volume, has recently been discovered in the interior of Tropical America. These birds, while they exhibit a strong affinity to the typieal plovers, have many points of resemblanee to the cranes; so that we can agree with Mr. Vigors in eonsilering QEdicnemus to "lave an affinity with the earlier groups of the Gruide," forming part of our Ardeade; and that they thus connect the present family with that.

(198.) The family of Trinomas contains the most typical waders, as the snipes, woorleocks, and sandpipers. This group is distinguished from all others by the great length, the slenderness, and the flexibility of the bill, no less than by the delieacy of their legs, and the smallness of the hinder toe. Like the plovers, they are endowed with great powers of flight and of locomotion; since they run with vast eelerity, and have the faeulty, in part, both of diving and swimming: the bill is even longer than the plover's; but insteal of being divided, as it were, into two portions, as in those birds, the eulmen is uninterruptedly straight, and the upjer mandible is not suddenly bent downwarls. The sandpiper or the snipc will give an accurate idea of that general formation which belongs to the whole family. Their geographic dispersion is as wide as their locomotive powers are great. The shores of every part of the world abound with sandpipers and curlews; and the European whimbril (Numenius Phoropus") is even said to have been deteeted on the eoasts of New Holland.

(199.) 'The genera comprised in this family will now be 
briefly glanced over. The true curlews (Numenius) have the same long, and generally curved, bill which distinguishes the ibis, but the ehceks and the throat are covered with feathers: the former are chiefly restricted to warm climates; the latter oecur more frequently in colder regions. It is worth remarking, that the three species known in liurope are not found in North America, but are replaced in that continent by three others, equal strangers to the European shores. In the avosets (Recurvirostra), the eurvature of the bill is exactly reversed, the point turning upwards instead of downwards, giving a most unusual appearance to this organ, and which is not found in any other of the order: one speeies belongs to Europe, another to Asia, a third to Amcrica, and a fourth to New Holland. This type seems to be the most aberrant of the Tringida: its toes are completely webbed, and it probably represents Phonicoptcrus in its own circle. In Totanus, which comprises many of the Furopean sandpipers, the species arc numerous, and many examples occur in Britain, - as the green sandpiper, the spotted snipe, the redshank, and the common sandpiper. This vernacular name is probably derived from the whistling or piping notes which are uttered by these birds as they run on the sands. They are dispersed all over the world, and are perpetually wandering from one locality to another: the toes are generally free; but sometimes, in speeies which lead off to other genera, there is a small membrane. The suipes (Scolopax), and the woodeocks (Rusticola), are too well known to require a popular notice of their habits or strueture: the true woodeocks are found both in Europe, Ameriea, and Asia ; and seem to be further represented in the hot latiturles of the Oll World by the elcgantly marked gemus Rynchcea. We pass over several slighter variations seen in the individuats of this fanily, and'searcely sufficient to constitute subgenera. The Phalavopes, or lobefoots, generally placed near the above genera, may here bc mentioned, as being the only group furnished with lobes to their vol. II. 
feet sufficiently broad to assist them in swimming. The immerliate affinities of these curious birds, however, are very doubtful.

(200.) The RALLID王 comprise the rails and waterhens, and constitute a very natural and well-markel family in the order of waders. They have bcen designated by these familiar names, from their peculiarly harsh notes, and by assuming much of the appcarance of gallinaceous or rasorial birds; another proof that the true analogies of nature are often perceived by the vulgar, although passed over by the scientific. The most prominent differenees in their structure, when compared with the foregoing families, is the great size of the leg, and the length of the toes, particularly the linder one: the body is very thin, and unusually flattence; a structure particularly adapted to the habits of rails, since they live for the most part in the thick and entangled recesses of those reeds and aquatic vegetables which clothe the sides of rivers and morasses. They are, for the most part, solitary and timid birds, hicling themselves at the least approach of danger, but quitting their semi-aquatic retreats in the morning and cvening, to fect in more open spots : their flight, from the shortness of the wings, is very feeble, but they run with swiftness; and, by the peculiarly compressed form of their body, are able to make thicir way through dense masses of reeds and high grass with so much facility as to escape, even after being desperately wounded. The flesh of all thesc birds is delicate; and, from living chiefly upon aquatic seeds and regetable aliment, they may be considered as aquatic Gallinacca.

(201.) The following are among the most obvious genera or subgenera which enter into the present group. Of these the jacanas (Parra) are the most singular: they are distinguished by toes of such remarkable length, that, by covering an enormous circumference, these birds can walk upon aquatic plants floating on the surface of the water, with as much ease and security as if they male their way over hard ground. Most of the species 
are armed with a short and formidable bony spur on the shoulder of the wings; and the head is either partially naked, or furnished with fleshy wattles. Several species occur in the liot latitudes of America, Africa, and Asia, but the genus is unknown in Europe. It is probable that the typical cluaracters of the family are best secn in the genera Rullus, Crux, Gallinulu, and Fulica. The purple water-hens are most beautiful and majestic birds, in size nearly as large as a fowl; they have a very thick and strong bill, the corneous front being continued over the fore part of the head like a helmet. There is a fine species found in the marshes of Sicily; and another, almost cxactly resembling it, in the distant regions of Australia. The genus Podoa probably belongs to the next order.

(202.) The TANTALiDA, or ibises, are large and very singular birds, living almost entircly on the swampy banks of rivers and fresh waters, and rarely, if ever, frequenting olyen shores like the more typical waders. Their habits and structure seem compounded of those belonging to the herons on one side, and to the rails on the other: their flight and size remind us of the former, whilc their long toes and insectivorous nature are more in unison with the latter. Tley differ from all others of the waders in having metallic colours upon their plumage, by which we trace their analogy to the Tenuirostres; and by their heads being frequently devoid of feathers, as in the Ampelide, and other tenuirostral types. The gcnera are few, but well defined and very remarkable; but there are so many marked intervals between them, that much difficulty exists in determining which are the aberrant forms. The majority live in tropical latitudes.

(203.) Having now enumcrated the chief groups in the five leading families of this order, let us endeavour to illustrate the families themselves, and see how far their analogical relations will sanction the order of progression in which we have here placed them. For this purpose we had better place this series of the Gral- 
latores by the side of that which constitutes the Insessores, and the following analogical characters may thus be more clearly stated.

$$
\begin{aligned}
& \text { Graliatores and Insessores. - Anulogies. } \\
& \text { Families of the } \\
& \text { Typical Characters. } \\
& \text { Tribes of the } \\
& \text { Insessores. }
\end{aligned}
$$

It will almost invariably he found, throughout all groups in the vast order of perchers, that those which represent the Conirostres have the bill longer, straighter, and more conic than any that belong to the subtypical group which follows it. Out of instances almost innumerable, which confirm this law, we may cite the woodpeckers among the Scansores, the true starlings in the circle of the Sturnide, the Coccothraustine among the finches, not to mention the same character in minor groups : hellce, also, in the families before us, the Tringide have the straightest and most conic bills of all those waders which possess the other typical distinctions ; and they thus show the perfection of their circle, just as much as the Conirnstres do of the other. We think that no unprcjudiced ornithologist will deny that the Charndriade, or plovers, are closcly and intimatcly connecterl to the sandpipers, and that these two families are the two most typical of the whole. Their general conformation, and the peculiarity of their being the only two which have the hinder toe, where it exists, elevated above the others, is, in our opinion, demonstrative evidence on this point: if this be conceded, it follows that the Charudriade are the subtypical group, and are consequently analogous to the Dentirostres. But how, 
it may be asked, can this be made out by actual analogy of structure? To this question we should merely call the attention of the inquirer to the peculiar sliape of the bill of the plover (fig. 22. a, Vol. I. p. 54.). Unlike that of all other walers, it secms compounded of two different forms : the basal half is straight and soft, like that of a Tringa; but the other extremity suddenly becomes thick, strong, and hard; the culmen rises abruptly, and then takes a regular curve downwards, so as to present a miniature resemblance, in its contour, to that form so universal among the Dentirostres: that the resemblance, or rather the analogy, is remote, naturally follows, because the groups themselves are very remote; yet this, in our estimation, does not affect the question, which is simply this, - Do not the plovers follow the sandpipers? - or, if this position was doubtful, it might be made a question of analogy; and then it might be asked, What family of the Grallatores presents the greatest resemblance to the Dentirostres. We know it is the opinion of some, that this resemblance is to bc found in the Ardeadre, rather than the Charadriada. And we will even confess, than in the early stages of our investigating this subject, we were of this opinion; the more so, because we have generally found that the locations assigned by Mr. Vigorsto the large groups or fanilies of birds arc generally correct, although, from want of analysis, we do not believe he has been equally fortuuate in the distribution of their contents. Be this, however, as it may, it seems to us, that if any groul among the waders is to represent the Fissirostres, that group is composed of the herons: no other waders watch for their prey from a fixed station; they are the largest of all the Grallatores; and, by their affiuity to the storks, they unquestionably pass into the rasorial circle : as for their possessing one of the rasorial characters, - that of long oruamental crests, - it is only another instance of what we have frequently alluded to, that in aberrant groups standing opposite each other, some of the typical characters of one will be imparted to the other. Our position, therefore, that in every com- 
prehensive circle there is one group eminently distinguished by crests, still holds good in this; and that the Grallatores likewise present us with another group of equal rank, where the wings are couvex and feeble, the bill short and hard, and the fcet remarkably large and strong, is abundantly proved by the rails, which are the aquatic poultry of the waders. Imperfection of foot, moreover, which is another of the fissirostral characters, must not be looked for in an orler like this, where the wholc of the families seek their food on the ground, and must thereforc bc able to walk remarkably well. These considerations, joined with others, one of which we shall presently notice, have lecided us in considering the Ardeade as the fissirostral type of the Grallatores; and we therefore pass to the next analogy, or that which we consider to exist between the Ibis and the Tenuirostres. The different modifications of the Linnsean genus Tantalus, ccrtainly comprehend those birds furthest removed from the typical perfection of the waders : their bill, although long, is more solid; the face, and sometimes the hcad, is naked (as we see in the Ampeide and other corresponding groups); and the plumage, totally unlike the more typical waders, is generally glossed with rich metallic colours: had they but reinarkably short legs, they would, in fact, be gigantic humming-birds; and even that which is entirely crimson finds its representative in such birds, similarly coloured, as analysis proves to be tenuirostral types. The analogy of the Rallide to the Rasores has already becn alluded to, and is too obvious to require further elucidation. We have, unfortunately, no space for lefining, so far as our researches have yet gone, what appear to be the precise limits or the connecting links of these families: but the primary groups, as now arranged, furnish a strong corroboration that the series is natural, merely from this result, - that we find the two first distinguished by having the hinder toe, where it exists, very sinall and elevated; whilc in the aberrant group, composed of the Ardeade, the Tantalide, and the Irallida, the hinder 
toe is fully developel, and is placed on the same level as the other toes. It would be highly interesting to elucilate other peculiarities of the grallatorial groups, by comparing them, in the above manner, with other circles; but this camnot, on the present occasion, be done, and we must now pass onward to the succeeding order.

\section{CHAP. XIV.}

ON THE ORDER OF NAIATORES, OR SWIMMING BIRDS.

(204.) THE last great division of the ornithological circle is composed of such families as habitually live upon the waters, and are hence called Natatorial. Their feet, which are almost always very short in proportion to the bulk of the body, arc geuerally placed far behind the equilibrium, and are thus especially adapted for swimming: the toes are rather long, and are more or less united by a thin, firm, expansilc membrane, or web: the feet may thus be compared to broad oars or paddles, which oppose a considerable resistance to the water, and enable these birds ro swim and dive with the greatest facility. They are the only order, except the waders, which have the neck very considerably longer than the legs, -a beautiful provision of mature, since they are thus unabled to scize their food considerably above or beneath the equal lcvel of the element they live upon. The structure of the plumage is particularly adapted to resist wet: its outer surface is close, compact, smooth, and somewhat oily; beneath this there is a second series of feathers, of a soft and downy texture, wlich is not only impenetrable to water, but calculated at the same time to keep the body in a constant and cqual state of warmth, and thus to guard the bird from those injurious effects resulting from sudden transN 4 
itions of cold and heat. As the ocean is their element, so do its waters supply their food: some live both upon aquatic plants and submarine insects; but the greatest proportion prey upon fisl, and those innumerable swimming and creeping things which subsist in the sea, and cover its shores.

(205.) The aquatic order has been divided into the following families*, which have every appearance of being the natural primary divisions: -1 . The Ducks (Avatid 2 ) ; - 2. The Gulls (LAlivis);-3. The Pelicans (Penicanima); - 4. The Penguins (Alcinж); -5. The Divers (CoLyußid are distinguished by the length of the wings, which enable them to fly well; while, in the two latter, these members are so sliort, that they seem perfectly useless for any other purpose than to serve the office of fins. A rapid survey of the prominent characters and groups of these families is all that can be here said of them.

(206.) The aualogies of the primary groups of the natatorial order have never been made out, and they are, in truth, involved in much difficulty; at least, if we are to judge from the trouble their investigation bas cost us. Tliere can be no doubt, indeed, that the typical perfection of the order rests witl those birds whose structure is more especially adapted for diving and swimming; and it therefore follows, as the result of this conclusion, that the Colymbidke, or divers, and the Alcidk, or auks, coustitute the two primary types: the lengthened and conic bill of the first of these families assimilates witl that form belonging to the Conirostres; and we may, therefore, safely infer that it represents that tribe. The Alcida, on the other hand, have a short and broad bill, considerably curved on the culmen, where it is gradually arched from the base; while the tip, although not toothed, is bent over thc lower mandible: this, in fact, is the general outline of the bill of dentirostral types, even in remote groups, such as the Psittacide, amoug the Scansores; and it is

* Vigors, Linn. Trans. xiv. 
rather singular that these auks are often called seaparrots: this analogy, indeed, has been remarked hefore; but without any suspicion, as it would seem, that both of these familics were deutirostral types. We now come to the aberrant families, in which a most singular commixture of characters is to be found. It has, as we conceive, been abundantly proved, that the first, or rather the most prevalent, of all the charactcrs assigned to the rasorial type of nature, is a marked instinct for domestication. If we follow up this theory for the purpose of deciding which of the remaining three is the rasorial family of the natatorial order, we must at once fix upon the Anatide, or ducks; for, whilc nearly onc half of the species in this group have been domesticated, time out of mind, in all countries, and by all civilised nations, there is not a single species among the two remaining. families, the pelicans and the gulls, of which the same can bc truly affirmed,- both, in fact, are peculiarly wild and untameable, living, for the most part, on the ocean, and only frequenting the land for the purpose of breeding, or to perch and fish from a rock. Having now made out, in some mcasure, the analogies of three of the fannilies, there remain two otlers, the Pelicanide and the Larida, and we are to determine which of these is the most aberrant; in other words, which has the least developement of the natatorial characters. By putting the question in this shape, we are immediately led to fix upon the gulls, from thcir having the longest legs of all the Natatores, and also from their labits being the most tcrrestrial; thcy are, in point of fact, the waders of the swimining order, as every one knows who has seen them walking on the shore, intermixed with their prototypes, the true Grallatores. If this theory be correct, - and it seems well borne out by the facts of the case, - it inevitably follows that the Pelicanidae are analogous to the only remaining type, - that is, the fissirostral or natatorial: this is not only the thcoretical conclusion we slould arrive at 
from what we have already stated, but is that also which will result from attentively considering the characteristic distinctions of this farnily. As representatives of the natatorial form, they have the sliortest feet of any birds in existence; they live upon the ocean; and they are the most bulky of the order: as, on the other hand, representing the Fissirustres, the tip of their bill is suddenly looked; they have an enormous wide mouth; and they possess, above all others, the most astonishing powers of flight.* Condensing these remarks into a tabular form, we may state the analogies thus:-

Anarogies of the Natatomal Families.

Families of the General Analogies. Tribes of the Orders of
Swimming Order. Ge
Insessores.

Colrabinde. $\left\{\begin{array}{c}\text { Pre-eminently typical of } \\ \text { their own eircles; } \\ \text { lengthened, conic. }\end{array}\right\}$ Conirostres. Insessores.

A LCIDA $\quad\left\{\begin{array}{c}\text { Bill short, arched above, } \\ \text { the tip bent down. }\end{array}\right.$ DrNtirostres. Raptores.

Pelecanids. $\left\{\begin{array}{l}\text { Size large; mouth very } \\ \text { wide; fect very short } \\ \text { and imperfeet; live at } \\ \text { sca. }\end{array}\right\}$ Fissinostres. Natatonis.

Laride $\quad\left\{\begin{array}{l}\text { Bill slender; nostrils very } \\ \text { long; legs lengthened; } \\ \text { ambulating, but web. } \\ \text { bed. }\end{array}\right\}$ Tenuirostres. Graclatores.

Axatida: $\quad\left\{\begin{array}{c}\text { Eminently domestic } ; \\ \text { wings short, convex. }\end{array}\right\}$ Scaxsones. Rasones.

(207.) Now this exposition will, probably, be thought, by most of our readers, sufficiently satisfactory; and yet the experienced; ornithologist, who remembers what we have advanced on a former occasiont, will perceive it is beset with many difficulties and apparent contradictions. These we shall now state, and endeavour to answer. It is far from our wish or intention to strengthen our theory by glossing over objections, as if all our conclusions were infallible, or that no exceptions existed to the truth of those laws which we venture to think have regulated the variations of the animal kingtom. We have been accused, indeed, of being too dogmatical;

- See more particularly, on the Tachipetes, Vol. I. p. 162.
+ Class. of Animals, 1. 25\%. 
and yet an impartial reader must have perceived our anxiety, on many occasions, to state all those points upon which we entertain doubts, that they may be dccided by others, rather than ourselves. And it is for the very purpose of doing this, in the present instance, that we have entercl much more into the analogies of this order than we intended, or than our limited space will sanction. The objectious, therefore, to the above tablc are these:-It has been seen among all the groups of the Irsessores, and cven among qualrupeds, that a broad and Hat muzale is one of the primary indications of the fissirostral type; it therefore would seen to follow, that that type, in the present family, must be the ducks, and not the pelicans: these latter, again, as in the genus Carbo, have that peculiar rigidity of tail which indicates the scansorial, and not the fissirostral structure: most of these birds, also, have crests upon their heads; a furthcr evidence of their analogy to the Rasores, and not to the Fissirostres. To these facts, and the inferences that might thus be drawn from them, we should reply, that this interchange of characters in the aberrant groups of an aberrant circle (for such is the Natatores among the orders of hirds) is by no means uncommon, and that we have repeatcdly adverted to it in other instances where the circle of affinitics were even stronger than in this. $\Lambda$ broad and flat bill is, indeed, one of the primary distinctions of the natatorial type, but it is not the only one; and when we find a preponderance of the characters of any given type found in any one particular family, it secms to us that we must look to the coincidences, and not to the exceptions. The same may be said regarding the stiff tails of the Pelicanide: this is the only scansorial character they have borrowed, as it were, from thc Anatide, who, in return, scem to have assumed the flat depressed bill of the fissirostral Pelicanide. On no other principle, in short, than the one above stated, can we possibly accoult for this singular combination of opposite characters found in the two extreme groups of the Natatores, - the Anatida 
and the Pelicanida. No great stress, after all, must be laid upon the rigid tail of the latter, because we find precisely the same character in the genus Chaturn, which is one of the most obvious fissirostral types. We were finally couvinced, however, of the analogy of the Pelicanide to the Fissirostres, by a circumstance apparently trivial in itself, but which, when viewel in refercnce to this intricate question, becomes one of high importance. According to some abservations which have been recently communicated to us *, the cormorant, after catcling a fish, is frequeutly, if not always, in the habit of throwing it up in the air and eatching it in its fall! just in the manner of the toucans and the hornbills. This unlooked-for and extraordinary demonstration of the fissirostral type appears to us perfectly conclusive, and supersedes all necessity for prosecuting this inquiry further.

(208.) The ANatrne, or ducks, constitute the first family of the natatorial circle, after quitting that of the waders. It includes a very natural, and for the most part a very strongly marked, group; wherein we have the freshwater and marine ducks, the geese and swans, the inerganscrs, and finally the flamiugos. All these are easily distinguished by their short, thick, and generally broad bills, the sides of which are furnished with flexible, lamcllar, transverse plates or ridges, which appear analogous to teeth, while the tongue is very large and fleshy. As it is unnecessary to dwell upon the general characters of birls so well known to ordinary observers, we may at once proceed to a slight glance at the prinary divisions above intimated, viz. - 1. The Anatina, or river ducks; 2. The Fuligulinu, or sea ducks; 3. The Merganina, or mergansers; 4. The Phanieoptince, or flamingos; and, 5. The Anserine, or geese. Each of these appear to hold the rank of subfamilies, for al though some contain but few forms, others - especially the two

- This has been repeatedly witnessed by one of my sisters, who, at a marine cottage we have at Hoylike, on tho Cheshire coast, was very fond of looking through a telescope at the cormarants, as they fished on the rocks
of Hilbury Island. 
first - are very full, and comprise both genera and subgenera.

(209.) The Anatince, or river ducks, slow the typical perfection of the whole family, in possessing that strong instinct for domestication so eminently characteristic of the rasorial type. They are very good swimmers, but not expert divers; this latter faculty being possessed in

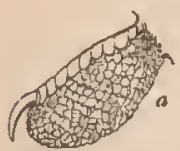

177

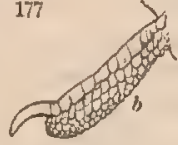

a much greater degree by the marine ducks of the ncxt division, where the hind toe (fig. 177. a) is much broader than in the fluviatile species (b): this difference, in fact, forms the typical distinction of the two divisions; and lowever inexplicable the fact may appear to us, it is nevertheless certain, that all clucks with a very broad hind toe are the most perfect divers. In the typical genus Anas, at the head of which stands the shoveller duck (A. clypeata Lin.); the lamelle of the bill project in different degrees beyond the margin. These, after describing their own circle of subgenera, are followed by the sheldrakes and Muscovy lucks. The beautiful genus Dondronessa Sw., composed of the summer ducks, next succeeds, as the rasorial genus; then follow the widgeons (Maecra); and the fissirostral type of Anserella, or the little geese ducks of India, conduct us back to the subgenus Boschas among the typical ducks. This, in our estimation, is the true circle of the Anatina.

(210.) The Fuliguliwe, or marine ducks, in their natural disposition bave none of the domestic habits of the last. They live out at sea, and, like all raptorial types are naturally very shy and wild; while their distinguishing character, as manifested in the structure of the hind toe, has already been explained. The genera are composed of -1 . Somateria, or the eiders, in which is the beautiful king duck (fig. 178.) ; 2. Oidemia, or the scoters; 3. Fuligula, or the pochards; 4. Clangula, or the golden eyes; and, 5. Heralda, or the long-tails. The analogical resemblances which these groups bear to the five genera of the frcshwater ducks are very striking, 


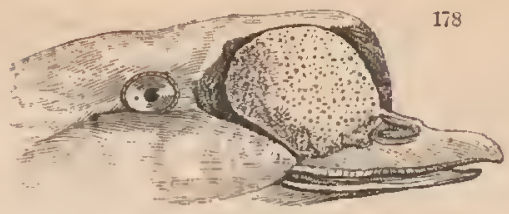

but we have no room to lay them before the reader. Among the Merganide the forms are very few, and consequently their circular succession cannot be traced.

(211.) The flamingos (Phonicoptinc, fig. 179.) have hitherto been arranged by all writers with the walers; and it must be confessed that their very long legs totally unlike the rest of the Anntide, is much in favour

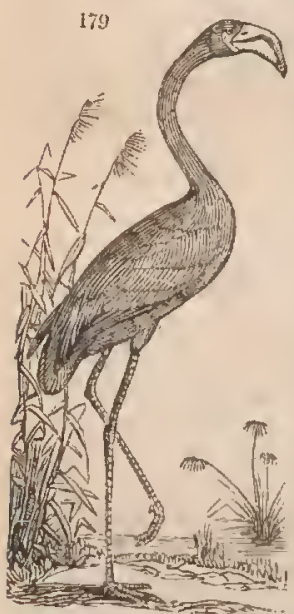
of such an arrangement. Nevertheless this character, however important, is not sufficient in it-. self to outweigh others still more so. Althougl the bill of the flamingo is bent, and otherwise greatly modified from that of a luck, it is essentially formed for performing the same office; the margins arc livided in to lamina, which shows that the food is taken in the samc way; while the feet, however long, have the wcbbed toes of a duck. We consider this form, in short, as no other than the grallatorial type of the family of Anntide; and did our space permit, wc should lay before the ornithologist the various tests by which this station may be demonstrated natural. It may be noticed, however, that even by its scarlet plumage it finds its analogy in the grallatorial family of Tantalidre, and even in Tichodroma, the corresponding type in the Certhiada; while a curved bill, and long legs, are two of the chief distinctions of all grallatorial representatives. As being 
the most aberrant of all the Anatide, the flamingo consequently becomes that form by which the Natatores are united to the Grallatores.

(212.) The Arserink, or geese, eonstitute the rasorial subfamily of the whole group. Although much nearer related to the true duck than are the flamingos, they are, nevertheless, inuch more terrestrial in their habits; and in their strong and high legs, fondness for grain and vegetables, and comparative shortness of wing, we trace unany of the chief characters of the rasorial type. The first form, after quitting theflamingos, seems to be the natatorial genus Cygnus, which, by its great length of ncck, and large sized body, softens down the interval between the ducks and the Phanicoptina. We next conie to the true geese, forming the genus Anser; the typical division of the whole group, and which contains most, if not all, of the usual subgenera. 'The tree geese (or ducks, as they have heen called) next follow; among which, the subgenus Chenaloplex will probably find a place. Plectropterus is the rasorial genus, analogous, by its spurwings, to the Rallide; while the Australian genus Cereopsis (equally representing the pigeons), appears alone necessary to complete this circle.

(213.) 'I'he remainiug families, not having been fully analysed, will be more briefly noticed. The Colymbin 2 are composed of the guillemots, divers, and grebes: with the exception of the last, they are all marine birls, with a lengthened,'strong, straight bill; the wings are generally remarkably short; and the fect placed so far back out of the equilibrium of the body, that they will not allow the birds to walk upon the land even so well as ducks. Thcy are few in number, and these are chiefly confined to the nortlern regions, although some species of grebe occur both in South America and New Holland: the tails of all are remarkably short. The gencra yet determined are only four. The first (Colymbus) comprehends the true divers, of which all the three species hitherto discovercul are found on the shores of Britain. 
although much more common on the arctic circle. The second (Uria) includes the guillemots, distinguished from the last by the absence of the hiuder toe; and these again are confined to the Northern Ocean. The third and fourth are Podiceps and Podia, both of which agree in having the membrane bctween the toes divided into lobes, similar to those on the feet of the coot; but in the first the hinder toe is lobated, while in the latter it is simple. The grebes are the most imperfect flyers, since the divers have their wings not much shorter than sevcral of the ducks.

(214.) The Arcio s form the third principal family, and include the penguins, the puffins, and all those singularly constructed groups where the wings are abortive, or, in other words, assume more the appearance, as they perform the office, of fins: the fect, moreover, are so little adapted for walking, that even the obsolete toe, seen in the ducks and divers, is here generally wanting. We thus see the power of swimming devcloped in the most perfect manncr in birds which, in every other faculty, are the most imperfect in creation. The natural series of the gcnera, by some, have been commenced with Uria; by others, with some of the Alce, or puffins. 'The little auk (Mergulus) has been detached on account of its short, thick, and convex bill, the base of which is covcred with the frontal featliers: there is but one species, a polar bird, yet sometimes secn on the British coasts: this form may probably be represcnted in the southern hemisphere by the crested auks (Phaleris Tem.) - the species of which are but obscurely understood: the arctic puffin, and two other northern species, form the restricted genus Mormon. The great auk and the razorbill are now almost the only specics left in the original genus Alca of Jinnæus: the first is nearly the size of a goose, and is occasionally found in the arctic seas : this singular and very rare bird is totally without the power of flight; and thc latter species can only raise itself on wing just above the surfacc of the sea. 
The razor-bill lays but a single egg, and, like most of its tribe, lives upon marine insects and small fish. The true penguins (Apteniodytes) are more properly confined to the southern seas, where they represent our auks : they are, in general, much larger birds, and the feathers lie so close on the body as to appear like scales: the feet are placed so far backward, that, when upon land, the penguin stands nearly ercet; at such times they may be approached with ease; but when once they have gained the water, they swim with the ease and rapidity of a fish, springing several feet over any object that may impede their course, and then once more continuing their course. One species, the Apleniodytes chrysacoma, of Van Diemen's Land, is stated to proceed on land hy leapss or bounds, rather than by walking. On the whole, thesc are the most singular of all aquatic birls, and clearly point out that nature is about to pass from the birds to the fishes.

(215.) The Puricanides, or pelicaris, are arranged under the fourth division. These birds are very different from the last, for they fly witl ease, and even with swiftness. They are a large, voracious, and wandering tribe, living for the most part on the ocean, and seldom approach land but at the season of incubation: the bill is long, and armed at the ent with an abrupt look; the width of the gape is excessive; the facc is generally bare of feathers, and the shin of the throat is sometines so extensible as to hang down like a bag: by this curious organisation, the pelicans are able to swallow fish of a very large size, and the whole family may be termed oceanic vultures. The genera may be thus briefly noticed:- Of the true pelicans (Pelicanus. there appear to be three or four species, all remarkable for the enormous size to which the skin of the throat can be expranded. One species (Pel. onncrotalus), which is the best known, is occasionally found in the South of Europe, and is frequently seen in menageries. The cormorants (Carbo) have the bill shorter, and the pouch much smaller; they are found in most latiVOL. 11. 
tudes, and not only fly well, but swim and dire with great swiftness. The provident Chinese avail themselves of these birds, wlich they train to catch fish, a ring being put round the neck to prevent the game being swallowed: thc common cormorant is a perfect example of this group. The gannet is the only British bird of the genus Dysporus, although several others have bcen discovered: they seem to be gencral wanderers over the whole world, and is that particular race which the frigate pelicans select more than any other as objects of attack and plunder. The listory of the frigate pelicans, no less than their whole structurc, is highly interesting: they are truly rapacious birds, endowed with a sight remarkably piercing, with an immensc expanse and power of wing, and with the most determined audacity; they attack other birds nearly of their own size, forcing them to disgorge or relinquish the fish they may have caught. We know not a more imposing sight thall half a dozen of these aërial birds soaring in mid-air, and suddenly falling down into the sea upon a shoal of fish that have approached too near the surfacc. At other times, during a storm, they soar to such a height, that, notwithstanding their size, they appcar but as specks in the firmament: all their powers of motion, in fact, are concentrated in the wings; for the feet are so short and imbecile, that when upon the ground they may be ap]roached with perfect ease. These birds, although common in the tropical seas, are not found beyond, and are thought to belong but to one species. The sanie regions, as tleir name implies, are inhabited by the tropic-birls (Photon), whose flight, although inferior, is frequently as high as that of the frigate-bird: there are but two species, both having two of the tail feathers very long. 'The darters (Plotus) terminate this family: they are distinguished from all the preceding by the excessive length and slenderness of the neck, which seems like the borly of a serpent united to that of a cormorant; the bill is very sharp; and this, 
joined to the form of the neck, renders it probable that they dart upon their prey something in the same manner as is done by the herons. Of two speeies already known, one is stated to Inhabit both the East and West Indies, hut this is somewhat doubtful.

(216.) The LaridAs, or gulls, constitute a much more numerous family than either of the three last. Their strueture is also more perfect, in a general sense, although inferior in that partieular construction which constitutes the perfection of the order, namely, the power of swimming and diving. The wings are very long; and the feet, although webbed, cnable these birds to walk about with perfect ease on the shore, in search of food: the hind toe is very sinall, sometimes wanting; but the legs are nearly as long as in some of the warling birds, of which thcy are the representatives: the bill is sleuder, mueh compressed, and is gradually, but not abruptly, bent. Gulls are well known to be gregarious, frequently associating in large flocks, and devouring every deseription of animal and vegetablc food: they swim with tolerable facility, but cannot dive well : their power of flying is very great, for many races are almost constantly upon the wing, and they brave the most violent storms. Most of the genera are universally distributed.

(217.) The genera may be noticed in the following order:- The terns, or sea-swallows (Sterna), constitute the fissirostral type : they have remarkably long wings and slender bills; the tail is forked; and the plumage generally is of a delieate pearl white, with more or less black upon the head: the speeies are numerous, and oceur in both hemispheres. 'The extraordinary genus, Rhynehops, or skiminer, although possessing much of the general halits of the terns, is eminently distinguished by the singular form of its bill (Vol. I. p. 72.), the upper mandible of which is considerably shorter than the under, and appears as if one third of the length had been broken off : three speeies have been described, to which we now add 
a fourth : they skim over the surface of the ocean with great swiftness, and scoop up small marine insects and other animals. The true, or typical, gulls (Larus) are a numerous race, dispersed in every clime, and so closely rescmbling each other in plumage, that many of the species are even now but imperfectly understood ; thcy bear a close rescmblance, in general appcarance, to the terns, but the bill is stronger, and the upper mandible much mere curved towards the end: many are of large size; and all are voracious devourers of fish, and of every marine animal, dead or alive, which is cast upon the shore: they particularly abound in northern latitudes, but seem to range over the whole world of waters. The parasitic gulls (Lestris) are the raptorial representatives, and are almost confined to cold regions: they are known by their stronger conformation, their different shaped bill, and the rough scales upon their feet: these birds, like the frigatc cormorants, derive their chief supply of food by robbing their more feeble congeners; they pursile the largest gulls, and make them disgorge or relinguish their liard-earmed game. The black-toed and the aretic gulls belong to this group, and both are occasionally seen on the northern shores of Britain. The genus Diomedia includes the well-known and gigantic albatrosses, the most powerful anct bulky of the whole fanily; they are oceanic biris, living almost constantly out at sea, but are more particularly abundant in the Pacific Ocean: we have no examples in Britain, or, indeed, in Euroue : the extent of their outspread wings is enormous; yet their flight, cxcejt in stormy weather, is by no means lofty: like all the rapacious birts of the ocean, they are most voracious, and their flesh is rank and repulsive. The genus Ifaladroma comprises such of the albatrosses as have the bill more rescnibling that of the petrels, while they agree with the former in being destitute of a hind toe; but only one or two species have as yet been clearly ascertained. The true petrels (Procellavia) have the lower mantible trunc- 
ated, we have a native example of this genus in the fulmar ( $P$.glacialis), but nearly all the rest inhabit the antarctic regions: they are continually out at sea, even in the most violent storms: Cuvier mations, that their lirench name of Prit Pierre is derived from their habit of walking on the water by the help of their wings. The shearwater petrel, and some others, have been separated under the very objectionable namc of Puffinus, from the different construction of their nostrils, and of the lower inandible: there is one species, the English puffin (1'. Anglorum 'l'em.), which appears to be confined to the northern coasts of Scotland. The genus Thalassidroma Vig. differs from the other petrels, by having the legs longer, and the bill somewhat shorter: it is composed of thosc small birds well known to sailors by the vulgar name of Mother Cary's chickens. We may here also mention the subgenus P'achyptila, as being that form which, of all in this fanily, shows the nearest approach to the Anatide, with which we commenced the circle: the bill retains the general form of the petrels, but the base is considerably dilated, and its inner margins are found to be furnished with tecth-like laminse. 'The most aberrant type of the Iaride appears to be the genus Dromas of Paykull, a long-legged birl, analogous to the flamingos: this wc have never yet seen, but 'Temminck and others consiler it has an affinity with the terns. The circle of the Laridce, no less than that of the natatorial order, has now been traced, and we can only regret that our limited space prevents us from laying before the reader some of the very many analogies by which this arrangement may be confirmed.

(218.) With the following diagram, which concentrates the latest results of my investigation of the ornithological circle, I shall now close this part of the treatise. There have been times, during its progress, when the discovery of what I considered a fresh glimpse into the harmouy of creation has imparted a confidence and a boldness to my style, which m!any may attribute 
to arrogance and self-sufficiency. It may be so: and yet it has only been thesc fits of enthusiasm which have borne me onward, amidst those doubts, and discouragements, and difficultics which always attend an original line of investigation. When I reflect, that what is now laid before the public, is the fruit of thirteen years' study and meditation - almost incessant - I feel at times even painfully scnsible that these results are so inadequate to what might have becn expected; and that much more might have heen accomplished, if the same labour had - been bestowed upon the subject by others. "Few, indeed, can be morc diseatisfied with the imperfect conclusions containet in these volumes, than myself; and I almost regret that I have brought them before the public in such an unfinished state. Had health, and fortme, and freedom from professional duties permitted, I should have elaborated this part of my researches much more, by visiting the public Museums of Europe, adling more to my own by extensive purchases at home, and by employing collectors abroad: but few private fortunes can command these resources; and no assistance or patronage, in cases like this, can be expected from our goverument. 'The scientific world must therefore rest satisfied, or dissatisfierl, with what I have been able to do, small as it appears. Misapplications of my own theory will, doubtless, be found in the subsequent pages; and those who will point them out by making a better arrangement of the groups, upon principles equally universal and comprehensive, will deserve well of inc, and of science at large. But these errors, however nuinerous they may be, touch not the theory itself. Whatever may befall other circles, those of the Psittacida and the Pisinno I have found the most perfect; and they are consequently those which, in the most minute details of variation, are the best calculated to test the truth of the theory itself. In the latter, more especially, I have even found three out of the five gencric circles to be actually perfect, even so far as my own limited knowledge extends. There is also a peculiar advantage 
attending the investigation of these two groups, as well as that of the Trockilida, which is this; - that however naturalists may differ about the primary nature of other birds, they will be unanimous respecting these; a parrot or a woodpccker cannot belong to any other groups than their own: Nature herself has separated and characterisel them from all others; so that the investigator knows at once the extent of the group he has to deal with, and he has only to make out its internal relations. In short, 1 consider the Piciance to be so perfect a circle, that I have been accustomed to view it, in all doubts and misgivings regarding others, as that upon which I coukl fall back, as upon a strong and impregnable hold, for demonstrating those first principles of the natural system I have, pcrhaps, too boldly announcerl. In regard to nearly all others, I may employ the words of two eminent writers who have had to contend with the same difficulties in the same line of inquiry. "When we cannot represent Nature as she is, we must endeavour to represent her as she appears to be; for if we suspend our observations in apprehension of committing an error, we shall soon cease to represent her at all."

- MM. Horsfield and Vigors; Linn. Trans. xv. 328. 


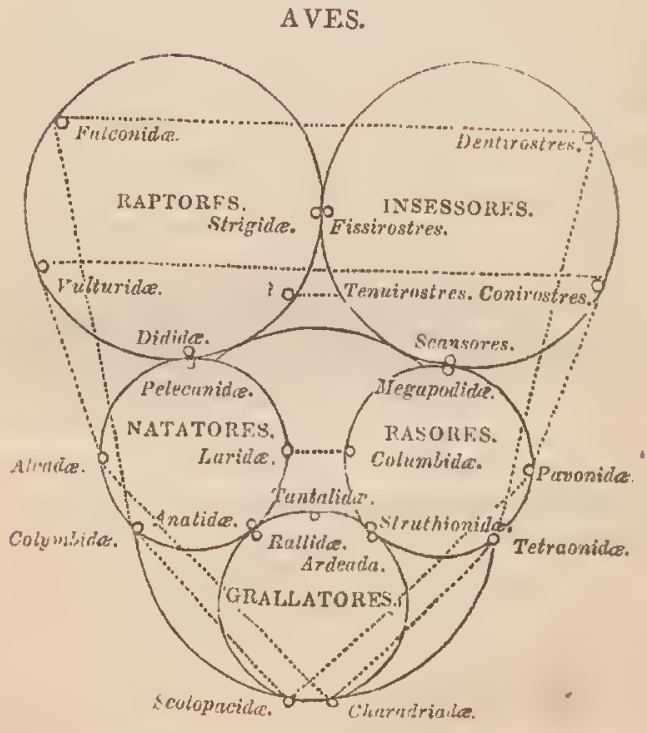




\section{PART IV.}

\section{SYNOPSIS OF A NATURAL ARRANGEMENT OF BIRDS.}

(219.) Is the following Synopsis there are a few alterations in the arrangement of the groups from what they appear in the foregoing part: this has resulted from further analysis, and by incorporating our researches up to the latest time. $\Lambda$ n attentive comparison of Gypogerunus with the Polylorus Braziliensis, and these again with some of the long-legged eagles, has at length convinced us that the first is no other than the rasorial type of the $\Lambda$ quiline circle: the more so, as its long legs and elegant crest are at once explained by this analogy. The numerous variations in the forms of the eagles and the buzzards induce us, also, to adopt Mr. Vigors's plan of considering the primary divisions of the Farconinds as so many subfamilies, rather than as genera, and in this group inany other alterations have been made. Our suspicions with regard to the situation of the genus Pipillo have been completely verified by the new species subsequently described; so that it will now be found (with Arremon as a subgenus) arranged in the Tanagrine circle. The genus Megapodius, and not Crax, turns out to be the type of the rasorial division of the Rasores; and Scolopax, instead of I'ringa, stands at the head of the Grallatores. The minor alterations it is not necessary to particularise.

(220.) The specific names, placed under each group are not always those by which the bird is mentioned in the work referred to; for many of the names used by these authors, cven when good, have not the claim of priority, or the birds have not been placed in the group under which they here stand: the nomenclature, therefore, must be rather considered our own, than that of 
the authors quoted; since, in such cases, we have used their figures as references only, without adopting their nomenclature. Where original specific names are not erroneous, or otherwise unobjectionable, wc have, as a matter of course, always retained then ; choosing, where necessary, such as have the alditional claim of priority. Our original intention was to have enumerated all the authenticated species of each group; but this plan, setting aside its difficulty, would have swelled the volume so much that it was soon abandoned. Those groups which we consider aENErIo are printed in capitals, the subgenera in Italics. 'There are some few additional ones, proposed by authors, which appear good; but as they liave not yet fallen under our examination, we have not, from ignorance of thcir affinities, ventured to adopt them.

(221.) We wish to take this opportunity of stating those principles which have guided us in the adoption of names, both generic and specific. There arc certain canons, in regard to nomenclature, long since laid down by the fathers of scicnce, to which all their followers, as we conceive, are bound to adhere: these, in the first instancc, regard the construction of names; and, secondly, their priority. Now it seems to us, that an author, who violates the first, has no title whatever to found his claim upon the second. Priority is a sure ground of preference, provided the preliminary conditions of securing it have becn complied with. We cannot, therefore, agree with those naturalists who allopt a barbarous, a fanciful, or a mythological name in ornithology, merely because it claims priority over another which is both classic and expressive; in other words, founded upon the primary rules of nomenclature, and thereforc having a legitimate claim for general adoption, which the other certainly has not. If we arc to take it as a principle, that priority alone is to guide us in our choice of names, we must act on that principle, and at once expunge all those other rules, laid down by Linnæus, to insure a system of classic nomenclature; we must cancel the names of M. Cuvier, and substitute 
those of M. Vicillot, - for the latter were certainly published first : but our innovations will not cease here ; MI. Cuvier's must give way to Brisson's, and many of these must be rejected for those of Willoughby and Ray. Let us see, therefore, liow this absolute rule would work in the family of Psittacida, - a group which has of late been overloaded witl a host of new names. Vieillot's Plictolophus must give place to Brisson's $\mathrm{Ca}$ catua, - still retained, indeed, by many of the French writers; Ara must be substitnted for Macrocercus; Psittacus, for Marcorave's name of Maracare; Tuiete, of Marcgrave and Ray, has the priority of Aympornis; and Jevdaya, of the same authors, must be used instead of Conurus. In this manner, if we wish to act strictly up to our rule of uneonditional priority, - and without so doing it would not be a primary rule, - we must reject four fifths of all the modern names, in order to do justice to the priority of others. We sec no difference, in fact, between these old designations, and many others recently published ; for Cacatua, Ara, and Maracura seem to be just as expressive as NTymphicus, Nestor, Electus, and many others of the same description. We should have thought, indeed, that the example set by the illustrious Illiger, no less than the excellent remarks upon nomenclature by Mr. Vigors *, would have induced our own ornithologists at least, not merely to have rejected such names, but to have excluded them altogether from their systematic writings, however useful they may be thought in the vernacular nomenclature of the Contincnt. Some allowance, again, ought surely to be made in favour of those ornithologists who patiently work out the details of their group, before they venture to publish a new genus, instead of merely taking what they think to be a new form, and at once publishing it as such; the chances being equal that it is only an aberrant species. Sir James Smith says, and we think very truly, that a botanist (no less than a naturalist) who undertakes to reform and elucidate a whole tribe, ought to be nnshackled in

* Zool. Journ, iii. 117., especially iv. 220 . note. 
every point in which he can be of service; he should be allowed to ward off, and to correct from time to time, all that may tend to deform and enfeeble his great object: he will have to choose between names of the same date, "und even between good and bod ones of any date." * Without in the least presurning to arrogate this authority to ourselves, we still, however, feel bound to make our humble lahours subservient to the spirit of these observations; and in the following Synopsis we have endeavoured to act accordingly. IVe further trust, that as many of our own generic names are in the rejected list, the purity of our motives in respect to the others will not be doubted, however we may be thought in error as to particular rejections.

(222.) In conclusion, we have used the following abbreviations to designate the chief part of those works we have quoted, the full titles of which have been given in our First Volume.

Lev. Af, , or Ois.d'Af., ?

or Ois. A. - - $\}$ Le Vaillant's Oiseaux d'Afrique.

Pl. Enl., or P. E. - Planches Enluminées.

Pl. Col., or P. C. - Planches Colorées.

Wilson, or Wils.

White, Voy.

Lewin, or Lew.

Selby

- Wilson's Ancrican Ornithology.

- White's Voyage to New Soutli Wales.

- Lewin's Birds of New South Wales.

- Illustrations of British Ornithology.

III. of Orn., or III. O. $\{$ Jardine and Selby's Illustrations of

Gould's Cent. $\quad$ - Century of Hymalaia Birds.

Gould's Monog. - Monograph of the Trogonidx.

Tem. Man., or T. M. Temminck's Manuel d'Ornithologie.

Lesson, Cent. - - Lesson's Centurie Zoologique.

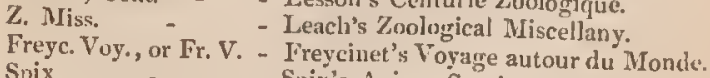

Spix

Lin. Tr.

- Spix's Avium Species Nova.

Vieil. Gal., or V. - Transactions of the Linnaan Society.

Vieil. Am., or O.

Vieil. Am., or O. Am, - Hist. Nat. des Oiseaux de l'Amerique.
Ois. Ch. - $\quad$ - Vieillot's Oiseaux Chanteurs.
N. Z.

$\begin{array}{ll}\text { N. Z. } & - \\ \text { Zool. IIL, or Z. I. } & -\left\{\begin{array}{l}\text { Zool ogical Illustrations, i. (first series) } \\ \text { ii. (second series). }\end{array}\right.\end{array}$

* Introduction to Botany, 2d ed, p. 383. 
Braz. B. - - - The Birds of Brazil.

IV. Af. - - The Birds of Western Africa.

Horsf. Java - $\{$ Horsfield's Zoological Researches in

Z. P. - - Proceudings of the Zool. Soc.

Z. Journ, or Zool. J. - Zoological Journal.

Edwards, or Ed. - Edward's Nat. Hist. of Birds.

Brown, Hll. - - Illustrations of Natural Ilistory.

Lears - - Illustrations of the Psittacidie.

Sav. - - Savigny's Birds of Egypt.

\section{Order I. raptores. Rapacious Birds.}

Family VULTURID R. The Vultures.

Size large. Body thick, heavy. Bill and legs very strong; the former hooked, but not toothed. Claws but slightly curved, and hardly retractile. Hcad and neck, in general, more or less naked. Vututur, Linn. Nostrils naked, transverse. Wings with the fourtl quill longest. Head and bill destitute of caruncles. 'Tail

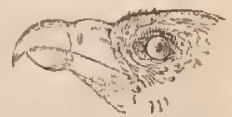

180)

feathers 12-1\%. Inliabits the Old W orld. (fig.180.) V. fulvus. Pl. Enl. 426. galericulatus. PI. Col. 1\%. auricularis. O.d'Af. pl. 18. indicus Ois. d'Af. 11.; cinereus. I'l. Enl. 425. Pl. Col. 26.

pondicereanus. PI. Col.2. monachus. Pl. Col. 426.

Cathantes, Illiger. Nostrils naked, longitudinal. Wings with the third quill equal to the fourth, and longest. Inhabits, witl one exception, the New World. Typical.

Sarcoramphus, Dumerel. Head and neck naked. Bill and feet strong; the former with an elevated fleshy caruncle. ( fig. 181.)

S. papa. Ed. 2. condor. 11. Col. 333. 40 s.

Cathartes, Illiger. Head and part of the neck naked, but withont caruncles. Bill and general construction weaker than in the last.
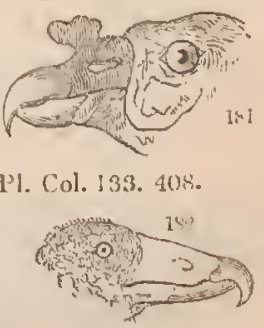
C. aura. Wilson, 75.1. (fig.182.) Californianus, P.C. 31 . atratus, Wilson, 75. 2 .

Neopiros, Savigny. Bill much lengthened, and remarkably slender. Nostrils longitudinal, nearly medial; cere occupying two thirds the length of the bill. Face and part of the neck naked. 'Tail

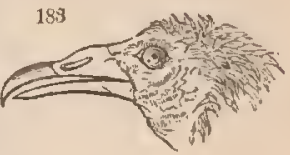
featliers 14. The tenuirostral type.

N. perenopterus. Ois. d'Af. pl. 14. (fig. 183.)

Camuerunus, Sw.* Bill short, thick, curved almost from the base, but the tip not hooked. Nostrils basal, and membranaceous; the aperture large, round, central, and nearly naked. Head and neck with only a few scattered feathers. Wings short, rounded. Tail broad, of eighteen feathers. Feet strong; anterior scales irregularly hexagonal: toes large; the lateral of equal length, and very little slsorter than the middle toe: all the claws long and slender. ( $f g .92$. Vol. I. p. 284.) The rasorial type.

C. Australis. Ill. of Orm. pl.140.

Grpä̈rus, Storr. Bill strong, lengthened : upper mandible elevated near the end, which is hooked; under mandible provided, beneath, with a bunch of setaceous bristles,

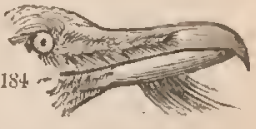
directed forwards. Nostrils oval, covered and defended by bristles. Fect short: the three anterior toes united to their base by a membrane; the middle toe very long: claws but slightly curved. Wings long; the first quill rather shorter than the second, the third longest. (fy. 184.) The fissirostral type.

T. inarbatus. Lilvards, 106. Europe.

\section{Famir FALCONIDA. The Falcons.}

Size moderate. Head and neck clothed with feathers. Bill curved, more or less, from the base: the tip of

- The Alecturus of Mr. Gray; but this nume having been previously given by Vicillot to a very distinct groug of flyeatchers, which $I$ have retained, it becane necessay for the to propose another. 
the upper mandible hooked, and very acute, with a tooth, or festoon, towards the end on each side, or with the cutting margin sinuated. Claws considerably curved, retractile, and very acute.

\section{SubFam. AQUILINE. Fagles.}

Size large. Body strong, robust, muscular; 'somewhat heavy. Bill rather straight at the base, but curved towards the end. Wings more or less lengthened; the three first quills graduated. Feet very strong and muscular: the tarsus more or less plumed: the claws large, and much curved.

Pavnon, Savigny. Bill rather short, rounded above, curved from the cere: the cutting margin of the upper mandible with a slight festoon in the middle. Nostrils small, obliquely transvcrse. Wings lengthened; the second quill longest. J Legs naked : tarsi entirely covered with small reticulated scales. Toes unconnected; the exterior somewhat versatile. Claws nearly equal, rounded beneath.

P. haliaetus,* Sav, Europe. Americanus. Wils. 37.1.

Aquila. Wings lengthened (the first quill short, the fourth and the fifth the longest, Tcm.). 'Tarsus plumed almost to the toes. Heal not crested. Inhabits chiefly the old World.

† A. imperialis. Tem. Man. 37. pennatus. Tem. Man. 43. chrysatos. P1. Enl. 410. albicilla. Selby, i. pl.3. navius. Ten. Man. 43. leucocephalus. Wils. 36.

Hampyia, Cuvier. IVings rather short. Tarsus more lengthened, and generally naked. Head crested. Inhabits the tropies of both the Old and the New World.

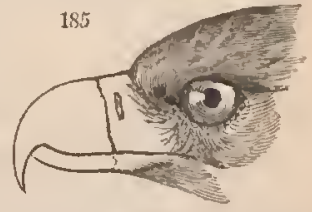

* So far as I can judge from figures and descriptions, I am disposed to consider the geneta Dakidion, Jamatorvis, and some others, to be secondary forms, or subgeneric types. Nut having thero before ne, I have not ven. tured to adopt them. I wish, in fact, that this arrangernent of the Falconide should be looked upon as mirely temporaxy, being now engaged on a more minute investigation of the whole family.

t These European species are inserted on the authority of the Manued d'Orzithologic, sd ed. 
H. destructor. P. C. 14. maculosa. Vieil. O.A.3. bis, (fig. 185.)

Guianensis. Daudin. occipitalis. Ois.d'Af. pl. 2. ornatus. Ib. 26. urubitinga. Pl. Col. 55. albescens. Ib. 3.

Gypogenanus, Illiger. Secretary. Legs remarkably long, and formed for walking. Bill shorter than the lead, large, strong, hookel, curred nearly from its base, which is coveresl with a cere. Nostrils ratler removed from the base of the bill, lateral; the aperture piereing the eere, diagonal, oblong, and open. Feet very long, slender. Thighs feathered. Tarsuslong, more slender at the base than at the upper part. Toes short; the auterior united at their base by a membrane; hind toe artieulated at the tarsus. Wings long; the five first quills the longest, and nearly equal. Shoulders armed with an obtuse spiue. - (Temminck, Man.)

G. serpentarius. Ois. d'Af. 25. South Africa.

Circaëtus, Vicillot. Bill robust, rather straight at its base; convex above, eompressed on the sides: eutting margin of the uppes mandible nearly straight, the tip hooked; under mandible straight, the tip obtuse. Nostrils oval, transverse. T'arsi naked, thick, and lengthened, covered witl reticulated scales. Toes rather short; the hinder and the lateral toes nearly equal. Claws rather short, nearly of equal length, and but slightly curved; the anterior and the posterior the strongest. Wings long; the third quill the longest. (Vieil.) The rank of this form scems to be subgeneric to the last: M. Vieillot intinates two spccies. C. cinereus. Vieil. Gal. pl. 12.

\section{Suban. CYMINDTNAE. Rïtes.}

Form slender. Bill rather short, the cutting margin sinuated, but neither toothed nor festooned; the tip very acute, and considerably hooked and lengthened. Feet, (typically) weal, very short; the tarsus not much longer than the hind toe and its claw; soles broad, destitute of pads; lateral toes equal. Wings long; the third and fourth quill longest. Inhabits ehiefly America. 
Iвyeren, Vieillot. Bill feeble, small, very slightly hooked; the cutting margin sinuated, but not festooned: under mandible nearly straight. Orbits, sides of the head, and part of the throat, more or less naked.

rather lengtliened ; the third quill longest. Tail lengthencd, rounded; the feathers very broad. Tarsi sleuder, moderate, naked: lateral toes un-

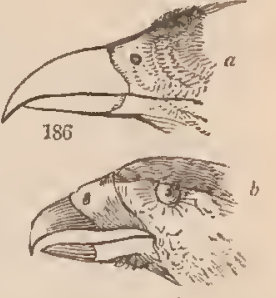
equal; the hinder toe much shorter than the inner toe. America ouly. (fig. 186.)

I. leucogaster. Vieil. Gal. 6.(a) ater. (b) Vieil. Gal.5.

PoLýnonv, Vieil. Form aquiline: size moderate. 13ill with the base ratlier straight. Nostrils oval, obliquely transverse. Orbits and face partially naked. Tarsi rather lengthened, naked, very slender. Toes slender; the iniddle much lengthened, the outer rather shortcr than the inner, and the hinder toe much the shortest. Claws but slightly curved. Tial moderate, broad. (fig.187.)

P. IBraziliencis. 'Zool. IIl. ii. pl. I.

CYMrsps, Cuvier. Bill high, the sides much compressed, with the hook considerably lengthened; the cutting margin irregularly sinuated, or nearly straight; under mandible small and weak. Sides of the head and orbits partially naked. Nostrils obliquely transverse, opening by a slit. Tarsi very short, not exceeling the hind toe and claw ; the anterior part plumerl half way from the knee. Joes broad, with fleshy margins; the two lateral exactly equal; the middle slightly longer, the hinder slightly shorter, than the inner toe. The claws nearly equal, except the exterior, which is smallest. Soles of the feet very broad, and without prominent pads. Wings long; the fourth quill the longest.

C. cuculoìdes. Pl. Col. 103, 104.

VOL. 11 . 
Naucuerus, Vigors. Bill small, weak, considerably hooked, with a small and ncarly obsolete festoon in the middle. Orbits and sirles of the head thinly provided with feathers. Wings very long; the first and second quill internally emarginate towards the tip. Tail very long and deeply forked. Tarsi very short, not longer than the hind toe, and claw; plumed half way in front, the remaining portion covered with angulated scales. 'Toes short; the two lateral almost cqual, the hinder nearly equal to the inner. Claws grooved beneath.

N. furcatus. Wils. 51.2. $\Lambda$ fricanus. Vieil.Gal.pl. 85.

Elanus, Savigny. Bill small, much compressed, the cutting margins slightly sinuated; the tip of the upper mandible very much hooked and prolonged; the cere short; nostrils large, oval. Wings very long, acuminated, reaching beyond the tail; the second quill longest; the first emarginated near the tip of the inner web. Tail short, almost even. Fect short, thick: the tarsus half feathered; the lowcr part covered with minute roundish subequal scales. Toes thick and free; the outer toe much shorter than the inmer, and of cqual length to the hinder toe. Claws large; the lateral and the hinder ones smooth and round; the middle claw sharply carinated on its inner sidc.

E. melanopterus. Le Vail. Af. 36, 37 .

Gampsonyx, Vigors. General structure of Elanus, but the wings are shorter, and the tail longer. Tarsus nore lengthened, and less plumed in front. Tail even. Outer toe shorter than the inner. Claws slender, nearly cylindrical. ( $f(y .188$.

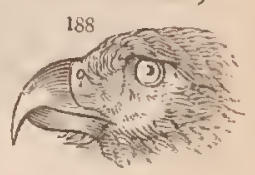

G. Swainsonii. Zool, Journ. i. 65.

Subarar. BUTEONINAs. Bus ards:

Size moderate: form slender. Bill small, slightly festooned, the base broad, the cere occupying one third the length of the bill. Head depressed and unusually broad. 
Feet moderate : the hinder toe much the shortest. Wings long. Hunt for their prey upon the wing.

MiLvus, Antiquorum. Bill small : nostrils elliptic. Wings much lengthened; the fourth quill longest. Tarsi short, slender. 'Tail lengthened, either forked or graduated. Claws robust. Fissirostral.

M. regalis. Vieil. Pl. Enl. 422. parasiticus. Ois. d'Af. 22. ætolius. J'. Enl. $472 . \quad$ sphenurus. Vieil. G. 15.

PERN1s, Cuvier. Honcy I3uzzurd. Bill curved from the base; the margin straight, the lores cloched with small seale-like feathers. Tarsi very short, covered with small reticulated scalcs, and half plumed in front. Toes protected above by transverse scales. Wings and tail long. Tenuirostral.

P. apivorus. Pl. Enl. 420.

Splzaërus, Vieil. Form aquiline, with the bill of a buzzard. Bill strong, ligh, curved from the base, with a prominent festoon. Orbits and lores covered with down and hairs. Wings short. Tarsi moderate, feathered. Inner toe, without the claw, shorter than than the outer. Rasorial.

S. cristatellus. Iil. of Orn. pl. 66 .

Buteo, Antiquorum. Head large, depressed: gape wide, extending under the orbits. Nostrils large, oval. Lores densely clothed with small compaet feathers. Bill small, with a very slight festoon, or none. Feet moderate. Hind toe very shori ; lateral toes unequal. Anterior and posterior scales broad, transverse ; lateral scales small, roundish. Wings long. Tail rounded.

B. litgopus. N. Z. pl. 28 vulgaris. N. Z. pl. 27.

Crrous, Bechstein. IIarrier. Bill weak, particularly high at the base, and greatly compressed throughout, with a slight festoon in the middle of the margin. Cere very large, nearly covering one lialf of the bill. Lores clothed with small feathers, and lengthened recurved bristles. Gape

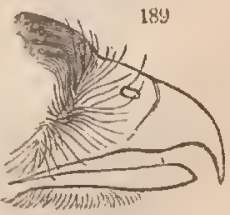


very wide. Ears large, surrounded by a ruff of small thick-set feathers. Tarsi very long, slender, smooth. (fig. 189.)

C. pygargus. Sellyy, pl. 10. E. rutilans. Pl. Col, 25. 3. Montagui. Vieil. G. 19. E.

\section{Sumax. FALCONINA. Falcons.}

Bill short, suddenly curved from the base. The upper mandible armed near the tip with a sharp angulated tootl, often double, beyond which is a slight festoon; under mandible deeply tootled at the end. Nostrils circular; cere short. Feet morlcrate; tarsi slender, naked; middle toe very long, lateral either equal or unequal, hinder very slort. Wings lengthened, pointer ; the sccond quill longest, and, with the first, deeply notched internaly, near their tips. Tail rounded.

Farco, Auct. True Faleons. Both mandibles of the bill with a single acute tooth near the tip. Nostrils round, naked. Wings moderate or long, pointerl; the first quill rather shorter than the second, which, with the third, are the longest. Tarsi slender, naked, with two series of anterior scales fitting into each other; the rest reticulate. Middle toe very long, equal to the tarsus; lateral toes rather unequal;

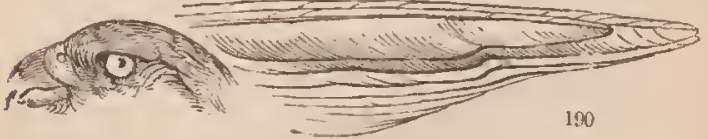

linder very short. The anterior claws of almost equal size. Soles with prominent parls. (fig. I 90.)

F. lanarius. Tem. Man. i. 20, unicolor. W. $\Delta$ f. i. pl.3. peregrinus. Pl. Enl. 42I. rufescens. W. Af. i. 109. subbutco. Pl. Enl. 432. Esalon. N. Z. pl. 25. tinnunculus. PI. Enl. 401. tinnunculoides. T. M. i. 31. rufipes. PI. Enl. 431. sparverius. N. Z. pl. 24. columbarius. W. pl.15.3. femoralis. Pl. Col. 345. ruficollis. W. Af. i. pl. 2. rupicolus. O. d'Af. pl. 35. tibialis. PI. Col. pl. 29. punctatus. 1b. 45 . frontalis. O. d'Af. pl. 28. macrodactylus. Ois.d'Af. pl. 30. and those iu Part 5. 
Harpagus, Vigors. Bill thickened; the upper mandible with two distinct teeth. Nostrils oval. Wings moderate, rounded; the first and second quills graduated, the third and fourth the longest. Tarsi slender; anterior scales transverse, in a single row; postcrior much smaller, rounded, sub-reticulated: mildile toe as long as the tarsus; lateral toes unequal, the outer longest, posterior very short. Three anterior claws nearly equal, hinder strongest. (fig. 191.)

H. rufipes. P. C. 38.228 .

cocrulescens. Edwards, 108.

diodon. P. Col. 198.

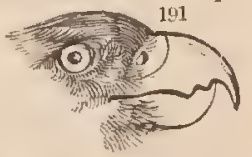

Lopnotes, Lesson. Bill small, much hooked, furnished on its sides with a groove: lores thickly clothed with feathers: the upper mandible with two small teeth. Feet very short. Tarsi plumed above, naked beyond, and fur-

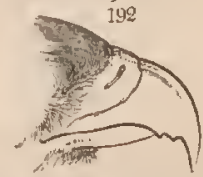
nished with smooth hexagonal scalcs; the (anterior) toes of almost equal length : claws very small, nearly all of the same size. Head crested. (Vide Temminck, Pl. Col. 10.)* (fig. 192.)

J. Indicus. Pl. Col. 10 . India.

Aviced A, Swain. (fig. 193.) Bill falconine; upper mandible witl two, lower with one, snall angular teeth. Nostrils transverse. Wings lengthened; the fourth quill the longest, the third slightly shorter; the first, second, and third, emarginate at their internal base. Feet very short. Tarsi not longer

* It is siugular that M. Temminck should take no notice, in his description, of the double tooth of this remarkable bird, althougls it is so distinctly expressed in his tigure, Pl. Col. 11\%, neither does he say any thing as to the length of the wings: the tail lie describes as even, while Lesson asserts it to be "un peu echancree!" 
than the hind toe and claw, plumed half-way from the knees; the scales irregularly liexagonal. Middle toe very long, exceeding the tarsus, even without including its claw; lateral toes nearly equal, the external shortest; external and posterior toes equal. Sole of the foot very broad, flattened, and without pads; all the toes free. Tail broad, moderate, even. Claws slender, moderate.

A. cuculoïdes. West. Af. i. pl. ].

\section{Surfam. ACCIPITRIN FE. Hawles.}

Bill short, suddenly curved from the base; the upper mandible armed in the middle of the margin with a large, obtuse, rounded tooth, or festoon; under mandiblc truncate at the tip ; cere modcrate. Feet moderate; tarsi in general smooth, naked. Middle toe lengthened; hinder not much shorter than the inner. Anterior claws very unequal, the inner being almost twice the size of the outer, and ncarly as strong as the hinder. Hearl small. Wings short; the quills internally emarginate at their base. Tail rounded.

Iotisia, Vieillot. Bill snıall, thick; a small, angulated, toothlike festoon towards the end of the cutting margin of the upper mandible; cere small. Nostrils round. Feet very short. Tarsi not much longer than the hind toe and claw: anterior scalcs large, transverse; lateral and posterior scales sub-hexagonal, the latter very minute. Basc of the tarsi and toes covered with very small reticulate scales. Toes short, strong, broad, lateral, unequal, the inmer and hinder almost of the same lengtl.. Wings very lopg; the third and fourth quills the longest. 'Tail short, even. ( $\mathrm{fg} . \mathrm{194}_{\mathrm{v}}$ ) I ophiophaga. Wil.25.1. plumbea. Vieil. Am. pl. 10.

Accipiter, Wrillughby. Sparrow Hawks. Size small. Form slender. Nostrils oval, oblique. Bill much compressed; the festoon in the middle of the cutting 
margin very prominent. Wings short, rounded; the fourth and fifth quills nearly equal, and longest. Feet lengthened, very slender. Tarsi long; the anterior and posterior scalcs remarkably smooth, witl their divisions scarcely pcrceptible. T'ues long, slender, with prominent pads beneatlı; inner toe considerably shorter than the outer; hinder toe shorter than the inner. Tail molerate, rounded, or cven.

A. fringillarius. P. E. 412.467. erythrorynchus. O. d'Af. i. penusylvanicus. Wils. 461

brachydactylus. W. Af. j.118. sexfasciatus. Purt 5. No.4. Aster, Auct. Gostawhe. Size large. Form robust. Nostrils large, oval, obliquely longitudinal. Bill short, the festoon prominent; lores thickly clothed witlı minute feathers. WVings short, often not reaching beyond the

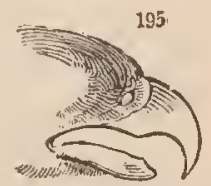
middle of the tail; the fourth and fifth quill ncarly equal, and longest. Feet strong, moderate in length and size. Tarsi feathered beyond the knees, short, broad, transverse, and smootli; the divisions prominent: posterior scales the same; but those towards the knec joint, and the lateral scales, are small and reticulate. Lateral tocs unequal, the posterior sliortest. Hinder and inner claws nearly equal, and particularly large ; iniddle and outer claws half the length of the forner, and nearly equal. ( $f$ ig. 195.)

A. palumbarius. N.Z.ii.pl. 26. monogrammicus. W. Af. i.

? borealis. Wilsoln, 52.1 ,

albus. White, Voy. 35.

pl. 4. musicus, O.d'Af. i. pl. 27.

\section{Halicetus, Savigny. Fish} Hawks. Size and form intermediate between Aster and Aquila. Bill large, straight where covered by the ccre, strongly curved and hooked

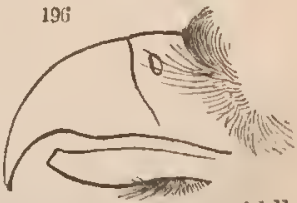
beyond. Margin with a slight festoon in the midlle. Cere rather large, occupying nearly one third the P 4 
length of the bill. Nostrils oval, obliquely transverse. Wings lengthened; the third quill longest. Feet rather short. Tarsi slender, feathered beyond the knees; the front and baek smooth. Anterior scales transverse ; posterior as if in one entire piece; lateral scales, and those at the base of the toes, very small and indistinetly reticulate. Toes strong; inner toe the shortest of all. Claws grooved beneath, unequal ; hinder and inner nearly of the same size, outermost mueh smaller than the middle. Tail broad, rounded. (fig. 196.)

H. I'ondiceriauus. PI. Enl. 416.

Note.-How far the other species, placed in this group by authors, agree with the above definition, cannot be ascertuined. I lave, therefore, taken the characters entirely from this one species, which seems to have an equal, and perhape a greater, claim to a station in the genus Pondion.

\section{Family STRIGIDA. Owls.}

Head very large. Eyes surrounded with a circle of radiated feathers, forming a facial disk; plumage soft, lax. Ears large. Feet generally feathered to the toes; outer toe direeted outwards. Bill more or less short, thickly protected by basal bristles : upper mandible entire, lower notched. Feed and fly during night.

STr1x, Linn. Typical Owls. Head and facial disk very

large: the former generally without egrets; the latter complete, and margined by a border of narrow stiff feathers. Ears very large; the eonch protecterl by an operculum or lid. Feet moderately long, scantily feathered.

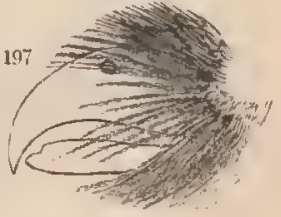

Strix. Head enormous, wider than the body, without egrets. Bill somewhat lengthened, and straight at the base. Tarsi rather long. The middle elaw serrated. Ears and opereulum very large.

S. flammea. Selby, Pl. 124. badia. Horsf. Java.

Scotiaptex, Sw. Head smaller, without egrets. Oper- 
culum of the ears large, and covering the orifice. Tarsus short, and thickly feathered. Tail graduated, considerably lengthened.

H. cinerea. N. Z. pl. 31. Uralensis. Pl. Col. 27.

Scotophilus, Sw. Operculum of the ears very small. Head without egrets. Tarsus short, feathered to the claws. Wings and tail rounded.

S. Tengmalmi. N. Z. pl. 32. Acadica. Wils. iv, pl. 34. 2. Otus, Ant. Head smaller than the circumference of the body, and having short egrets. Wings long; the second quill longest. Ears large, operculated. Feet moderate. O. Europacus. Selby, pl.190. brachyotos. Wils.iv, pl.33.3. Asro, Antiq. Horned Owls. Heal large, furnished with a double crest or egrets. Fars and facial disk inoderate, and the latter not always perfect. Ears without an operculum. Mill short,

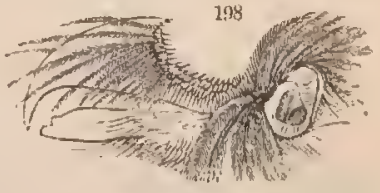
with the upper mandible sometimes festooned. (fig. 198.)

A. bubo. Pl. Enl. 4S5. Virginiana. Wils. vi. pl. 50. 1. Heliaptex, Sw. Habits diurnal. Head small. Facial disk almost obsolete. Ears very small. Tail moderate. Feet feathered to the toes.

H. arcticus, N. Z. pl. 32.

Scops, Antiq. Seops Ouls. Size very small. Facial disk very imperfect. Wings long. Middle and inner toe nearly equal. 'Tarsus moderate.

S. Zorca. Pl. Finl. 436. Senegalensis. W. Af. i. 127. leucotis W.Af. ii. 124. rufeseens? Ilorsf. Lin. Tr. 11. Col. 16. xiii. 110.

Nyctia, Savigny. Eagle Owls. Size large. Head small, without egrets, and almost without the facial disk. Eyebrows prominent. Ears very small. 'Tarsi short, thickly feathered. Tail sliort. Wings rather long.

N. candida. Wils, iv, pl. 32.1. 
Nyctipetes, Sw. Sparrow Owls. Size very small. Facial disk obsolete. Ears very small. Wings very short, rounded. Tail moderate, rounded. Tarsi of variable length. Middle toc lengthened. ( $f i g, 199$.

* N. periatus. W. Af. i.130. t cunicularia. Bon. Am. O.pl.I. Survia, Dumeril. Hawk Ouls. Size large. Head and ears small. Facial disk imperfect. Wings long. Tail considerably lengthened, cuneated, or graduated. Flight diurnal.

S. funeria. Wils. vi. pl. 50. f. 6 .

Order II. INSESSORES. Percling Birds.

\section{Trine DENTIROSTIRES.}

\section{Family LANIADE. Shrikes.}

Bill with a very deep notch, or prominent tooth, at the tip of the upper mandible. Claws acute.

SUbFam. LANIANE. True Shrilies. Lateral toes equal and free. Claws slender, acute. Bill generally short, with the tooth very prominent.

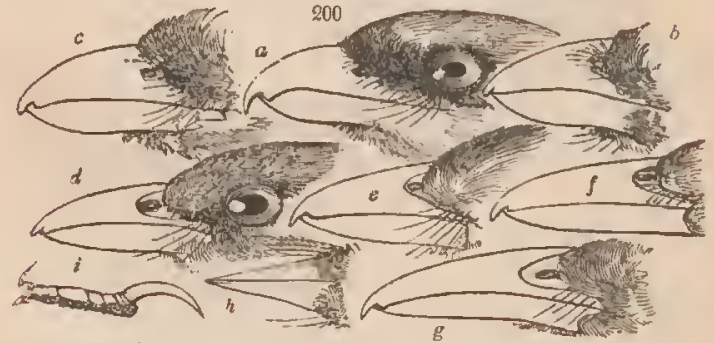

LAsius, Linn. Bill very short, strongly hooked; the

* Trroneously named a Sculophilus.

+ Probably the tyje of the whole. 
tooth very prominent. Wings moderate, somewhat pointed. Tail rounded, or slightly graduated. Lateral toes free, and equal. Claws ( $f i g .200 . i$ ) acute.

L. excubitor. P. E. 4.5. $(a, h)$ collurio. P. E. 32. f. 2. excubitoides. N.Z. ii. pl.34. collitris. O. d'Af. i. pl. 61 . borealis. N. Z. pl. 33 . elegans. N. Z. p. 122. meridionalis, P. E. 32. f. 1 . rufus. I. E. 9. f. 1. flavirostris. W. Af. i.233.(c) Hardwickii. Gould's Cent. pl. 12.

superciliosus. Ib. pl. 12.

TEnophonus, Sw. Bill more lengthened, slightly hooked; the tooth smaller. Wings very short and rounded. Tail lengthened, graduated. Isateral toes free; the inner very slightly shorter than the outer.

leucogrammicus. (fis. 200.d) lonqirostris. Part 3. No.6. (g) erythropterus. Uis. d'Af. collaris. O.d'Af.ii. pl. 67. (f) pl. 70. e)

Chдтовlemma, Sw. (fig. 201.) Bill short; the tip merely eurved, and the tooth obsolete. Front defended by thick-set bristly feathers, directed forwards. Wings lengthened; the third quill the longest. Feet short, robust. Middle

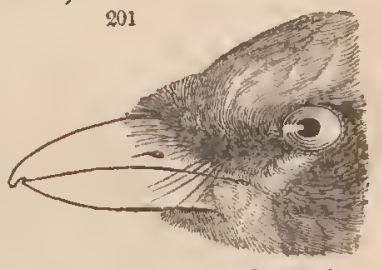
and linder toe of the same length; lateral toes free, nearly equal. The fissirostral? type. Analogous to Tephrodornis.

I. leveocephala. Sw. Part. 3. No. 5.

Nruaus, Sw. Bill lengthened, slender, with a prominent hook and tooth. Wings moderate; the fourth and fifth quill lougest. Tail slort, and nearly even; the feathers narrow and obtuse. Tarsi moderate, slender Inner toe shorter than the outer. Tenuirostral?

N. capensis. Ois. d'Af. ii. pl. 71. (fig. 121. p. 13.)

Falcuncurus, Vieil. Bill very short and broad; the hook slight, and the tooth small. Wings moderate. Tail divaricated, or slightly forked. Feet semiscansorial; the hind toe lengthened, and longer than 
the middle toe. Claws broad, curved. The scansorial type.

F. frontalis. Lewin. pl. 26 guianensis. Braz. B. 58. Australia.

S. Anerica. (fig. 200.b)

\section{Subrax. THAMNOPHILIN 王. Bush Shikes.}

Lateral toes unequal; the outer connected to the first joint of the middle toe. Claws broad, and not very acute. Bill lengthened, abruptly hooked at its tip; the tooth prominent.

Thamnopmuss, Vieil. Bill strong, abruptly hooked; the gonys ascending. Wings very short and rounded; the four first quills graduated. Tarsus rather long; the lateral scales more or less divided. Inner toe considerably shorter than the outer, and deeply cleft: outer toe connected to the middle as far as the first joint. 'Tropical America only. Colours dark.

T. gigas * Fr. V. pl. 18, 19. nigrer. Less. Cent. pl. 19. guttatus. Spix, ii pl. 35. 1. cinnamomeus. Zuol.J.ii.87. doliatus. Z. Miss, i. 16.

lineatus. Ib. i. p]. 6 .

bicolor. Braz. Birds, pl. 60 . navius. Ib. pl. 59 . badius. Ib. pl. 65,66 .

torquatus. Ib. p. 89.

ambiguus. Ib. p. 91 .

pilcatus. Ib. p. 01 .

ferrugineus. Ib. p. 92 .

pectoralis. Part 5 . No. 7.

Malaconotus, Sw. Bill strong, abruptly hooked; the gonys ascending. Wings moderate or short, rounderl; the three first quills graduated. Tarsi rather long; the lateral scales in an entire piece. The toes as in Thamnophilus. Tail slightly rounded. Tropical Africa only. Colours bright.

M. olivaceus. W. Af. i. pl.22. atrococcineus. Z.J. ii. [1.76. cruentus. I.ess. Cent. p. 6.5. torquatus. O. d'Af. pl. 286. superciliosus. W. Af. 239. erythrogaster. Rüpp. AL 29. barbarus. Ib. pl. 24.

chrysograster. Ib. pl 25 mo leucotis. Part 5. No.178, orientalis. Part 5. No. 179. Prionops, Vieillot. Bill more slender; the base, and front of the head, defended by long setaceous feathers,

* Striatus, if retaincd to this species, gives an erroncous idea of the markings, which are not stripes, but bands. 'The subgenera are not yet determined. 
directed forwards, and hiding the nostrils. Wings long, ample, and rounded; the four first quills graduated. Feet slender, feeble. Lateral scales entire. Tarsus rather short. Middle toe not much longer than the outcr, which is again longer than the inner; hind toe lengthened. Tail rounded.

\section{P. plumatus. West. $\Delta$ f. pl. 26.}

Colluricincla, Vigors. (fig. 202.) Bill much compressed, and the tip not so abruptly hooked. Nostrils partially covered with setaceous feathers and bristles. Wings rather lengthened, and pointed; the first quill only half as long as the second; the

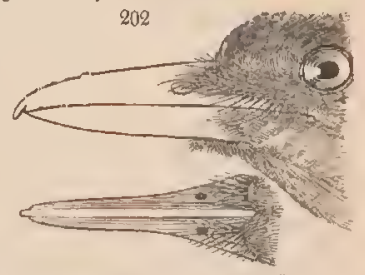
three next nearly equal, and longest. Tail moderate, evelı. Feet strong: the lateral toes unequal; the outer longest, and slightly connected to the middle. Claws acute. Lateral scales entire. Australia only. Tenuirostral.

C. cinerea. Iiv. Tr. xv, p. 214. strigata. Part 3. No. 8.

Subram. DICRURINÆ. Drongo Shrikes.

Bill compresscl towarils the end ; the culnen gradually arched, and bent over the lower mandible. Feet short. Tail lengthened, generally forked. Wings long, and more or less pointed. luhabits the warm latitudes of the Old World.

TEPhrodonnis, Sw. (fig. 3. p. 8.) 13 ill resembling Prionops; the base and the nostrils being partially coveres witl procumbent setaceous feathers and bristles. Wings moderate, roundel. 'Tail rather short, perfectly even. Tarsi and toes sliort; the lateral toes unequal; hinder toe longer than the tarsus.

T. superciliosus. Part 3. No. 9. virgatus. P. C. 256. f. 1. Melasoma, Sw. (fig. 204.d) Bill of the general shape of Dicrurus, but much more slender and delicate. 
Nostrils partially naked, with a few weak incumbent bristles at the base. Rietus strongly bristled. Wings morterate; the three first quills graduated, the three next of equal length. Tail rounded. Tarsus lengthened; equal with the middle toe, and longer than the hind one. Inner toe scarcely shorter than the outer. Africa. Allied also to Brachypus.

M. edolioides. West. Af. i. pl. 29.

Ocy ртиячs, Cuvier. (fig.201.b,e) Bill gradually arched from the base, where it is very broad. Culmen thiek and convex, without any ridge; the base dividing the frontal feathers, and somewhat dilated. Rictus bristled. Nostrils wide apart, naked, small, without a nembrane, and pierced in the bill. Feet short, strong. Wings very long and pointed; the first quill longest. Tail short. India and Australia.

O. leucorynchus. Pl. Enl. 9. f. 1.

Analcipus, Sw. (fig.203.) Bill with the general structure of Ocypterus, but more eonic. Rictus smooth. Wings lengthened, nearly as long as the tail ; the first quill spurious; the seeond much shorter than the third, fourth, or fifth, which are equal and longest. Tail

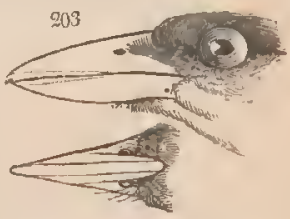
short, even. Feet short, weak. Hinder toe shorter than the tarsus. India and South Africa.
A. sanguinolentus. P’. Col.
bicolor. O. d'Af. pl. 73.

hirundinaceus. [3art 5. No.11.

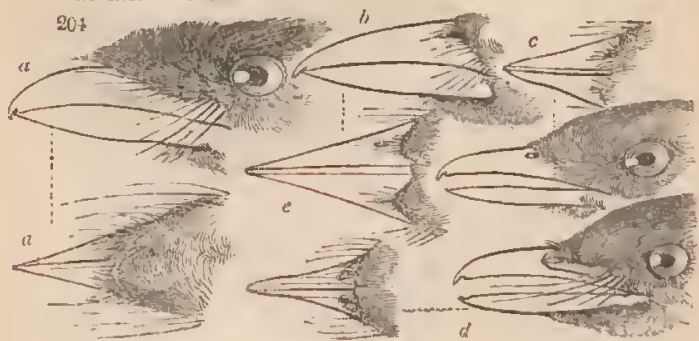


Dicrurus, Vieillot. (fig.204.a) Bill wide at the base, much compressed beyond; the culmen considerably arched, and curved at the tip; base of the bill, and the nostrils, hid by incumbent rigirl feathers and strong bristles. Wings long, pointed, but-with the three first quills graduated. 'Tail long, forked, and generally lyrate. Feet very. short. Hinder toc and claw as long as the middle onc, and equal to the tarsus.

D. cinereus. O.d'Af. pl. 170. atripennis. W. Af. i. 256 . casipennis. W. Af. i. 254.

\section{Suram. CEBLEPYRINA. Caterpillar-Catchers.}

Bill broad at the base, but destitute of long bristles. Rictus ncarly smooth. Wings pointed; the three first quills graluated. Feathers on the rump very thick, and apparcntly spinous. 'I'ail with the centre emarginate, and the sides rounded. Feet short; latcral toes unequal. Warm latitudes of the Old World.

Cemrerviris, Cuv. (fig. 115. p. 6.) Bill strong; the culmen considerably arched. The nostrils concealed by very short, compact, incumbent, and somewhat rigid fcathers. Rictus with a few short bristles. Wings with the fourth quill longest. Lateral toes uncqual. Tarsus longer than the linder toe. Colours plain.

C. mentali. H. and V. Lin. Tr, sv, pectoralis. W. Af.i, 249.

Oxy norus, Sw. Bill strong; the base broad; the culmen elevatcd and arched; the tip considerably hooked; both mandibles notcherl; front defended by rigid diverging feathers. Rictus strongly bristled. Feathers of the head thickly interspersed with setaccous hairs. Wings and tail rounded. Ficathers on the back very rigid. Tarsi strong. 'The claws large and curved. *

O. ferrugineus. Freyc. Voy. Atlas, pl. 17.

Campeimana, Vieillot. (fig.204.c) Gencral structure of Ceblepyris, but smaller and weaker. Bill sur-

- I am not without suspicion that this mny prove to be a Lanius, in the disguise of a coblepyris. The only specimen f lave ever seen is in 1 ?aris. I camot, (hutcore, at this time, re-examuse it. 
rounded with setaeeous hairs. Rietus bristled. Wings short, not reaching mueh beyond the tail covers ; the two first quills equally graduated. Rump feathers very thick and spinous. Tail very broad slightly rounded. Feet short, weak. Colours bright. C. phonicia. W.Af. i. pl.27, 28. atrata. O.d'Af.pl.164-5. Phonicornis, Sw. General strueture of Campephaya, but the nostrils and gape are entirely destitute of bristles or setaceous feathers. Rump feathers nearly of ordinary softness. Wings moderate; the first quill spurious, and not half so long as the seeond; the third and fourth longest. Feet short, weak. Tail lengthened, nearly even; the feathers narrow.

P. flammeus. Zool. Ill. ii. miniata. Gould's Cent.pI.8. pl. 59. peregrinus, Ib. pl. 9 .

Erucrvora, Sw. General strueture of Campephaga, but the bill is more lengthened and eompressed from the middle. Front and rietus entirely smooth. Wings moderate; the fourth and fifth quills longest. 'Tail broad, roundel. Rump feathers not rigid. Tarsus slender, lengthened, as long as the midllle toe.* Upper tail eovers very long.

E. orientalis. (Turdus orientalis, Auct.)

\section{Subam. TYRANNIN E. Tyrant Shrikes.}

Bill very straight, short, depressed its whole length; the culmen not arehed, but the tip abruptly hooked. Nostrils and rietus defended by bristles. Feet short, small, and slender. Lateral toes equal, or very nearly so. Claws long, slender, fully curved, and very acute. Ameriea only.

Ptilogonys, Sw. Habit of Phonicornis, but the rump feathers quite soft. IBill very short, rather strong, triangular; the base compressed; the culmen gently arehed. Rictus smooth. Nostrils large, membran-

* In all the other Crblepyrinc the tarsus is shorter than the midale toe. 
aceous; the aperture naked, and nearly round. Feet very short, strong. Legs feathered below the knees. Wings moderate; the first quill spurious, the two next graduated. Tail lengtlened, and slightly forked. 1'. cinereus. Z. I. ji. pl. 62.120. nitens. P'art 5. No. 16. CInrsoLol'nus, Sw. Walling Tyrants. Bill lengthened, as long as the head; the sirles eompressed. Rictus bristled. Wings rounded; the two first quills gradually pointed at their ends; tertials lengthened, nearly as long as the primaries. Fcet large, formed for walking. Lateral toes equal. Tail even. Brazil.

C. ambulans. Sprix, ii. pl. 23.

Satrophagus, Sw. Bill lengthenel; the sides eompressed; the tip abruptly hooked, and deeply notched. Gonys thick, aseending. Wings molerate. Feet moderate, stout. Lateral toes equal.

S. sulphuratus. Pl. Eurl. 269. pusillus. Part 5. No.12.

Megratoma, Sw. Habit and general strueture of Sauropluggus; but the bill is very large, and broad along its whole length. Inner toe shorter than the outer.

M. Alaviceps, ruficeps, and atriceps. Part 5. No. 13, 14, 15.

Trrannis, Vieillot. Typical Tyrunts. Size large. Bill of different sizes, but always broad and depressed. Wings rather long; the primaries abruptly sinuated, and pointerl at their tips. Feet small, and gene rally fieble; the inmer toc shortest. 'The claws slell.. der, strong, very acute, and fully curved. Tail moderate, broad, more or less forked.

'T. intrepidus. Wilson, pl. 13. f. 1.

IMilvulus, Sw. 'Tail considerably lengthened, and very deeply forked.

M. forficatus. Pl. Enl. 677. longısemir. Ill. O. i. pl. 42. Tyrannuri, Sw. Little Tyrants. Size, in general, small. II abit and general structure of Tyrannus, but the tail is never forked, nor the primary quills abruptly sinuated or pointed at their tips."*

* The subgeners of the last, and more particularly of this group, which VOL. 11 . 
T. audax. Sw. Monog. No. 3. crinita. Wils. pl.18. f., 3. borealis. N. Z. ii. pl. $35 . \quad$ sibilans, \&c.

FamiLy MERULIDAE. Thrushes.

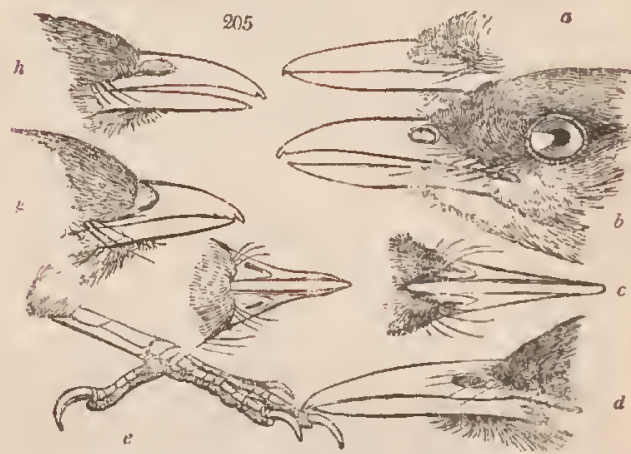

SUAFAM. BRACHYPODIN年. Short-footed Thrushes. Feet very short. The hind toe almost as long as the tarsus. Claws short, broad, and much curved. Bill distinetly notched. Wings short, rounded. Feathers on the rump very long and thick set. ( $f$ ig. 205.)

Micnopus, Sw. (fig.205. c, d) Bill as long as the head, straight, somewhat conic, but the culmen gradually arched. Tarsus remarkably short, feathered beyond the knees. ( $f i g .206 . c$ ) Lateral toes unequal ; hinder as long as the tarsus. Wings moderate; the first quill almost spurious. Tail even.

M. calcocephalus. Pl. Col. 43:3, - melanoleucus, * Hypsepetes. Vigors. Tail forked.

P. psaroides. Gould's Cent.

Brachypus, Sw. Bill shorter than the head; the base broad; the sides compressed: culmen elevated, and curved from the base. Rictus generally furnished

is very numerous in species, have not yet been sufficiently andiysed. There are unany remarkable modifications of structure; but all, as I believe of a subordinate nature.

* Turdus melanoleucus Gray. 


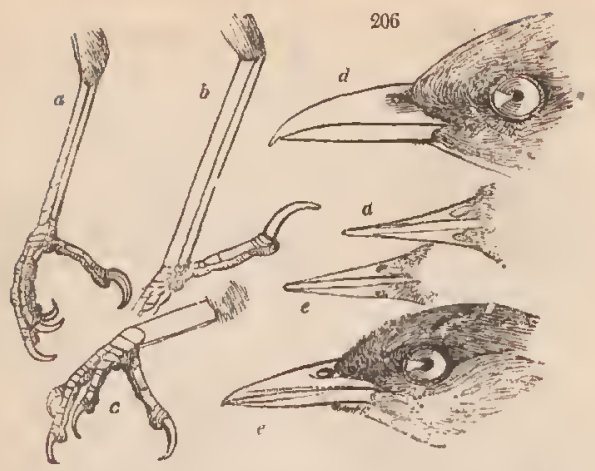

with bristles. Feet very short, strong: tarsal scales entire. Tarsus longer than the hind toe. (fig. 205.e) Claws curved, broad, acute. Wings and tail rounded. Brachypus, Sw. Bill short. Rictus bristled. Feet small, weak: latcral toes equal; hinder toe as long as the tarsus. (fig. 208.a)

B. dispar. P. Col. 137.

Chloropsis, Jardine and Selby. (fig. 206.d) Bill more lengthened; the tip much hooked; the notch of the upper mandible forming a small distinct tooth. Rictus or gape smooth. Feet sinall: lateral toes unequal; the hinder toe rather shorter than the tarsus.

C. Malabaricus. P. C.512. f.2. gampsorynchus. 111. O. pl.7. Cochinsinensis. P.C.484.2. cyanopogon. P. C. 512 . f. 1. aurifrons. P. C. 484. f. 1. mysticalis. Part 3. No. 48. Sonnerati. Ill. Orn. pl. 100.

Jora, Horstield. (fig. 206. a,e) Bill nearly as long as the head, lengthened, somewhat conic, and rounded. Rictus smooth. I'arsus rather lengthened; the anterior scales divided. Middle and hinder toe of equal length. Tarsus much longer than either. Tail very short, fasciculated; the tips truncate and even.

J. scapularis. Horsf. Java. melaceps. O. d'Af. pl. 141. Andropadus, Sw . (fig.205. f,g) Billvery short, resembling 
that of Brachypus, but the upper mandible is crenated near the tip. Neck with setaceous hairs. Rictus bristled. Wings, tail, and feet as in Brachypus.

A. vociferus. O. d'Af. 106. f. 2.

Hamatornis, Sw. (fig. 205. $h$ ) Head crested. Bill short. Rictus bristled. Feet short: latcral toes unequal; hinder toe shorter than the tarsus, which is equal to the middle toc. Wings and tail rounded.

H. chrysorrhoïus. O. d'Af. iii. bimaculatus. Linn. Tr. xiii. p.. 107. 2. p. 147.

melanocephalus. Ib. 106.1. erythrotis. Dixon's Voy. hamorrhous. O.d'Af.107.1. Pl. EnI. 508.

'Tricopuonus, Temminck. Bristle-neck. (fig. 207.) Culmen gradually arched. Nostrils and base of the bill surrounded with lengthenext slender hairs. Gape very strongly bristled. Margins of the mandibles white. Feathers of the crown and chin elongated. Nape of the neck furnished with several conspicuous lengtliened bristles, very considerably cxceeding the surrounding featliers. Feet short. 'Tarsus longer than the lind toe, and feathered beyond the knees. Inner toe shortest. Wings and tall moderate; the former with the three first quills much sracluated.

T. olivaceus W. Af. i. 264. (b) strigilatus. W. Af. i. 267. gularis. Ib. i. $266 .(a)$

Pirymastrephus, Sw. ( fig.205. $a, b)$ Bill as long as the head, strong, the tip rather hooked. Rictus strongly bristled. Frontal feathers small, compact, directed forwards, and compressed on the base of the bill. Wings and tail molerate, rounded. Fect short, strong, robust. Tarsus and middle toc of the samc 
length; lateral toes unequal, the inner shortest: hinder toe shorter than the inner one. $\Lambda$ nterior tarsal scales divided.

P. capensis, O. d'Af. 112. f. 1. seanters. W. Af. i. pl.30.

Icteria, Viell. Bill with the general form of Bruchypus. but the culmen more elevated and arched, and both mandibles entire. Wings and tail rounded. Tarsus cousidcrably lengthened and strong. Inner toe the shortest ; micldle toe very long. Ainerica. (fig. 206. b. 208.6)

Icteria polyglotta. Wilson, pl. 6. f. 2.

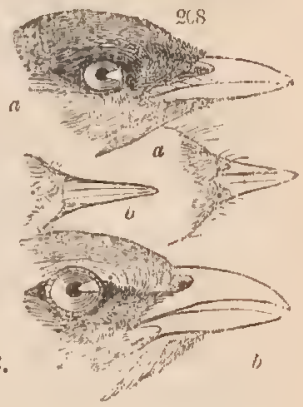

SubFar. MYOTHERIN As. Ant Thrushes.

Bill straight, somewhat cylindrical; the tip suddenly bent down or hooked.

Dasycephata, Sw. Bill as long as the head, straight; the tip abruptly hooked, the base wide, the rest somewhat cylindrical. Gonys strong, ascending. Nostrils and front of the head defended by rigid feathers and bristles, pointing in different directions. Rictus strongly bristled. Tarsus lengthencd, slender : lateral scales numerous, small, oval. T'oes and claws slender: inner toc shortest; outer toe connected to the midlle as far as the first joint. Hind claw large. Wings and tail rounded.

D. rufesecens. Braz. B. pl.76. syndactyla. W. Af, i. 261. Mrominis, Illiger. Fcet lengthened, rather stout. The lateral scales of the tarsus in onc cntire piece. Claws not broad, nor greatly curved. Bill as in the small Thamnophile. Wings short. Tail moderate, rounded.*

* Urotomus, Formicivora, and all the other small Myothere, having the feet weak, aud the tarsal scales and claws similar to those of Thannophilus, Q 3 
Myothera. Inner toe longer than the outer, and cleft to its base; outer toe with its first joint united to that of the middle toe. The tarsus with the anterior scales dividerl.

Drymophilu, Sw. Inner toe shorter than the outer toe, which is only slightly connected to the middle. Tarsus (typically) very smooth: all the scales entire.

D. longipes. Z. Ill. ii. 23. leucopus. Zool. J. ii. 150. fasciata. Ib. ii. 27.

Brachypteryx, Horsfield. Legs very long. Tarsi slender, smooth: all the scales entire. Lateral toes equal. Rump feathers considerably elongated. Tropical India only.

B. montana. Horsf. Java. ptilosus. Ill. O. iii. pl. 150. Myocincla, Sw. Legs strong. Inner toe longer than the outer. All the tarsal scales divided. Anterior claws small ; hinder claw nearly straight, and as long as the toe.

M. colma. Pl. Enl. 821.

Pithys, Vieillot. Feet syndactyle. The inner lateral toe shortest ; the outer united by its first and second joint to the middle toe. All the tarsal scales entire.

P. albifrons. Vieil. Gal. pl. 129.

Prtra, Temminck. Bill strong, thrush-like: the culmen gradually curved. Nostrils nearly naked. Wings moderate; the first and second quills but slightly graduated. Tail remarkably short, almost hid by its covers. Feet very long, pale, the scales nearly entire. Inner toe slightly shorter than the outer. India and Australia.

P. gigas. Pl. Col. 217. strepitans. Ib. 833.

cyanura. Pl. Enl. 355.

brachyura. Edwards, 824. atricapilla. PI. Enl. 89.

cyanoptera. Pl. Col. 218.

versicolor. Z. Jour. i. 468. erythrogaster. PI. Col. 212. granatina. Ib. 506.

Chlorisoma, Sw. Bill as in Pitta, but somewhat thicker.

I think it better to refer to that group; but as it has not been analysed, 1 do not, in this work, incorporate these two subgenera, al though proposed by raself some years ago. 
Nostrils protected and nearly covered by incumbent feathers. Rictus bristled. Wings rounded ; the four first quills much graduated. 'Tail moderate, or lengthened, graduatcd. Feet strong, rather lengthened: the inner toe scarcely shorter than the outer. India. ( $f i g .125,126$. pagc 25.)

C. thalassina. Pl. Col. 401. Sinensis. PI. Enl. 620.

Grallaria, Vieillot. Bill thrush-like, as in Pitta. Wings rounded; the two first quills graduated, the first half as long as the second, the three next nearly equal. Tail short, and rounded. Legs very long: the tarsus slender, pale; the anterior scalcs divided, the lateral seales (typically) entire.t Latcral toes nearly equal.

G. rex. Pl. Enl. 702.

meruloides. 1ll. Orn. pl. 11.

Myophonus, Temminck. Bill strong, thrush-like; but the upper mandible greatly curved at the tip, and destitute of a notch. Wings rounded; the four first quills much graduated. Tail rather short, convex, even; the tip of the feathers mucronate. Legs lengthened, strong, black. Inner toe slightly shorter than the outer. Tarsal scales smooth and entire.

M. metallicus. P. C. 170 .

nitidus. Gray. (pl. unpub.)

Crnclus, Bechst. Bill moderate, rather slender, very straight, considerably depressed; the tip obsoletely notched; gonys ascending. Nostrils naked, membranaceous; the aperture very small and linear. Wings moderate, rounded; the first quill spurious. Tail very short, even. Feet large, very strong, pale ; the latcral toes equal: the tarsal scales entire and smooth.

C. albicollis. Selby pl. 45*. Pallasii. Gould, C. pl. 24. Americanus. N. Z. Bnn. Asiaticus. N. Z. ii. 174.

Orn. pl. 16. f. 1 .

Sumam. MERULIN E. True Thrushes.

Wings more lengthened, and pointed. Bill notched,

† It appears to me that Charmexa Vig. is more an aberrant species of Grallaria than a distinct type in the genus Potta: the only species known ehiefly differs in having the tail longer, and the lateral scales divided. 
with the culmen gradually curver to the tip, which is bent, but not hooked, over the lower mandible. Feet formed both for perching and walking.

l'etrocrscrs, Vigors. Rock Thrushes. Bill thrushlike: the tip of the upper inandible abruptly bent down, and nearly entirc. Wings moderate; the first quill spurious; the second shorter than the three next, which are equal, and the longest. Tail even. Anterior scales divided. Lateral toes equal. Claws small, but slightly curved.

P. montana. Ois. d'Af. pl. 101.

Petrophila, Sw. Bill thrush-like: the culmen and tip of the upper mandible gradually bont, and entire. Wings and tail as in the last. Lcgs pale: the anterior scales entire. Lateral toes unequal; the inner shortest. Claws moderate, and fully curved.

P. cyanocephala. Gould's Century, pl. 19.

Meruld, Willnghby. 'Bill moderate, straight; the culmen slightly curverl; the tip distinctly notched : the gape slightly bristled. Wings lengthened, pointed; the first quill spurious; the second a little longer than the third, which is longest. Tail morlerate, ncarly cven. Feet moderatcly long. Lateral toes almost equal, but the inner rather the shortest. 'Tarsal scales entire, smooth.

M. nigra. Selby, pl. 45. f. 4. torquata. Selby, pl. 44. f. 2.

Iliaca. Ib. pl 45. f. 3 . cyanotis. III. Orn. pl. 46.

Orphrts, Sw. General structure of Merula. Bill more curved in the culnen; the notch small, or nearly obsolete. Rictal bristles rather strong. Wings rounded; the three first quills graduated. 'Tail lengthened, graduated, or roundel. Inner toe manifestly shorter than the outer.

O. polyglottus. Wilson, pi. 10. f. 1. rufus. Wils. 14. f. 1. curvirostris, PI. Col. 44J.

Cossypha, Vigors. General structure of Orpheus, but the wings morc rounded; and the tail less so. The rictus smooth. Africa only. 


\section{MERULIDE, - CRATEROPODINE.}

leucoceps. W. Af. i. p. 282 vociferus. Z. I. i. pl. 180. albicapilla. Ib. pl. 32. superciliosa. O. d'Af. pl.11l.

Cи жrops, Sw. Bill moderate, thrushlike, notched. Nostrils basal, large, naked, meinbranaceous ; the aperture lateral and linear. Frontal featlers rigid ; the shafts eomposed of bristles. Chin feathers the same, but weaker. Rictus bristled. Wings very short, and rounded. 'Tail rather lengthened, broad, convex, soft, and slightly rounded. Tarsi very long and strong: anterior seales divided. Lateral toes unequal. Claws sinall, obtuse, and slightly curved; the three anterior of equal size. Africa, 1. ( fig. 209.)

C. Burchellii. N. Zool. ii. p. 487. pl. col. 385.

SUbFam, CRATEROPODTNE. Babblers.

Legs remarkably large and strong, with the claws but slightly curved. IVings short and rounded. Tail large, broad, graduated, and very soft. Plumage lax. Bill eompressed, straight, hard; the tip nearly eutire.

Pellolineum, Sw. Bill inoderate, straight, somewhat eonic; the tip notehed: gonys aseending. Frontal feathers small, rigid, directed forwards. Rictus bristled. Wings very short,

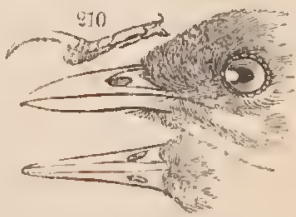
much rounderl. Tail moderate, graduated. Tarsus and middle toe of equal length; lateral toes mueh shorter, and equal; hinder toe shorter than the tarsus. Anterior elaws very small, and but slightly eurved. 'Tarsal scales scarcely divided. (fig. 210.)

P. ruficeps. N. Z. ii. p. 487. 
Crateropus, Sw. Bill nearly as long as the head; more or less straight from the base; much compressed; obsoletcly notched. Rictus bristled. Frontal feathers rigid. Wings slort, rounded. Tail large, broad, soft, and rounded. Feet very large

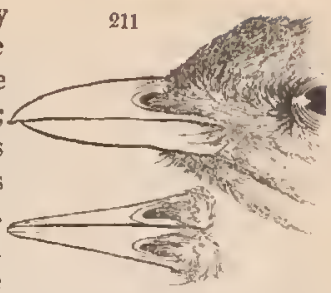
and strong. Tarsus lengthened; the anterior scales divided. Lateral toes nearly equal; hind toe large, nearly as long as the middle toe. Plumage lax, soft. (fig. 211.)

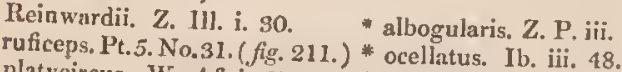

platycircus. W. Af. i. 274. * variegatus. Ib.

atripennis. Ib. 278.

oriolides. Ib. pl. 31 .

* pectoralis. Z. P. iii. 186 .

* erythrocephalus. Ib.

* squamatus, I.of O.ii.pl.4.

* chrysopterus. Z. P. iii. 48 . leucolophus. Lin. 'Tr. xi. pl. 15.* rufo-gularis. Ib.

Grats,ina, Vieillot. $\dagger$ Bill slender, straight, rather cylindrical above; the sides very little compressed; the base broader than high; the tips of both mandibles distinctly notched. Nostrils naked, basal. Rictus with a few bristles. Wings very long; the first and second quills graduated; the four next the longest. Tail lengthened, even. Feet strong, formed for walking, black; the anterior scales divided, the rest entire. Lateral toes equal; the middle toe and claw short, and very little longer than the lind toe. Australia.

$$
\text { G. melanoleuca. Vieil. Gal. pl. } 150 .
$$

Cinclosoma, Horsfield and Vigors. Bill very straight: the culmen and gonys equally curved towards the

* These birds I have not examined; but as' the character of the aupposed new genus, Ianthocincla, under which they have been placed, are (North. Zool. ji. proper group.

+ I have placed this singular type, on account of its very strong Iogs, in the present subfamily; but its precise station requires further analysis: it
is evidently a representation of Enicurus. 
point, which is slightly notched. Wings very short; the two first quills graduated ; the three next longest, and of equal length. Tail lengthened, broad, graduated; the feathers narrowed towards their tips. Under tail-covers excessively long. Feet moderate ; the inner toe longer than the outer. Australia:analogous to Accentor among the Sylviadce.

C. punctata. Shaw, 7ool. of N. H. pl. 9.

Malacocircus, Sw. Bill more or less curved, by being elevated at the base, having the sides much compressed, and the culmen high and arched: the tip almost entire, and not suddenly bent over the lower. Feet very large. Tail soft, graduated, generally lengthened.

Malacocircus striatus. Zool. Ill. ii. pl. 127.

Megalurus, Horsfield. Bill slender. Rictus bristled. Wings very short; the two first quills graduated; the four next all of the same length, and longest. Tail lengthened, graduated ; the feathers narrow. Feet

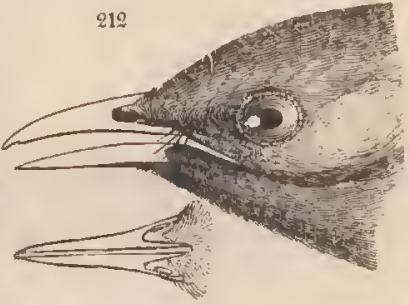
very large and strong. Toes lengthened; the inner toe rather longer than the outer. Claws slender, and but slightly curved. Anterior scales divided; lateral entire. India.

M. palustris. J. T. xiii. 159. cruralis. Ib.228. (fig. 212.) Pomatorhinus, Horsficld. General structure of $\mathrm{Cra}-$ teropus; but both mandibles of the bill are curved and entire, the wings shorter and much more rounded; the four first quills graduated. The tarsal scales entire. Inner toe slightly shorter than the outer.

P. montanus. Horsf. Java ; also Lin. Tr. xiii. 165.

* This, if it really belongs to Megalurus, is a very aberrant species. 
Timalia, Horsfield. Plumage lax. Bill straight, rather short, considerably eompressed: the culmen high, and gradually arched; the tip obsoletely notehed, or entire. Commissure eurved. Wings short, rounded. Tail more or less lengthened, graduated. Feet strong. Lateral toes nearly equal. India, Australia, and $\Lambda$ frica.

thoracica. pl. col. 76 . pileata. Hors. Java.

Aberrant? *

Phosphodes crepitans. Lin.

Tr. xv. 829.
Sphenura Africama. O, d'Af: iii. pl. 11‥ f. 2.

Dasyornis Australis. L. T. xv. 231.

Pteroptochus, Kittlitz. $f$ Feet of extraordinary size and thickness. All the anterior toes of nearly equal length. The claws long, slender, and but slightly curved. Tail rounded, of fourteen feathers, earried erect. Wings very short. Representing Menura and Orthonyx. Western Tropical America only.

P. megapodius. Z.I. ii. pl. II7. ruberula. Kittl. pl. 2. Kittl. pl. 4. albicollis. Ib. pl. 3 .

\section{Sumfair. ORIOLINA. Orioles,}

Bill thrush-like, as long as the head, broal at the base, compressed beyond: the base and the gapc devoid of bristles. Nostrils naked ; the aperture large. Wings lengthened. Rump feathers thick. Lateral toes unequal. Dosaconius, Sw. Habit and general strueture of Cratcropus. Bill lengthened, slenter; the culmen arched from the base; the tip looked and notched. Nostrils large, naked, membranaceous; the aperture large, oval, terminal. WVings remarkably short, and rounded. 'Tail inorlerate, broad, cuneated. Feet very large and strong. Lateral toes equal. Claws slender, acute, slightly eurved. Alneriea only.

D. vociferans. Zool. Ill. ii. pl. 72 .

* Of all these types, or subgenera, there is but a single example of each ; and as the whole of this subfamily requires a proper analysis, I have thought it best not to notice them, for the present, in a more prominent manner. 
Serrculus, Sw. Bill rather stout, resembling that of Oriolus. Nostrils naked. Wings moderate; the two first quills equally graduated; the third nearly as long as the fourth. 'Tail moderate, even. Feet strong, robust. The tarsus much longer than the hind toe; inuer toe shortest. Australia.

S. chrycocephlalus. Lewin, pl. 1.

Oriot,us, Limnæus. $13 i l l$ as long as the head; broad at the base; the tip distinctly notched, and somewhat hooked. Nostrils short, nearly naked; the aperture lateral, large, and oval. Wings rather lengthened; the first quill very short; the second not quite so long as the third, which is usually the longest. Tarsus rather short; longer than the hind toe and claw : the anterior scales divided. The Old World. Galbula. PI. Enl. 26. auratus. W. Af. ii. pl. I. Sinensis. Pl. Enl. 570. coronatus. Part 5. No. 181. melanocephalus. O. d'Af. 263.

Capensis.* O. d'Af.261-2.

IIodsonii. Part 5. No. 30. Zanthonotus. Horsf. Java. brachyrynchus. W. Af, ii. viritis. Ency. Meth. 696 . flavocinctus? L.T.xv. 327. meruloides? Ib. $x$ v. 327. Paradiceus. Elw. 112.

Irena, Horsfield. Bill of Oriolus; but the culmen much raised, and considerably arched from the base, and rather hooked at the tip. Nostrils partly defended by short plunes, which cover the membrane. Rictus slightly bristled. Wings and tail as in Sericulus. Feet small. 'Tarsus very short, scarcely longer than the hind toe and claw ; the anterior and lateral scales entire. Inner toe rather the shortest. Rump feathers very thick, and slightly spinous. India.

I. puella. Horsf. Java. Il. col. 70.

DUL,Us, Vieillot. Bill very sliort, much compressed, but with the culmen elevated and arehed. Conmissure curved. Nostrils as in Oriolns. Wings rather short; the first quill not half as long as the second; the

- The various names given to this species, as bicolor, monachus, and In roatus, being equally applicalle to four others, I have ventured to desigmate it by one which iudicates its peculiar locality. 
third, fourth, and fifth, longest; the secondaries with the tips notched; the tertials lengthened. Tail moderate, slightly forked. Feet as in Oriolus. Claws strong, broad, much curved. S. America.*

D. palmarum. Pl. Enl. 156. f.. 2. nuchalis. Part 5. No. 192. Smmeotumens, Vieill. Bill rather short, strong, par taking of the structure both of Dulus and Oriolus; the base broal, and the commissure straight; gape very wide, reaching to beyoud the eye. Nostrils naked; the aperture large, oval. Rictus smooth. Wings, tail, and feet, as in Dulus. Tarsus hardly longer than the hind toe and claw. Australia only.

S. viridis. Vieil. Gal. pl. 147. canicollis. Part 5.No. 117.

\section{Family SYLVIADA. Warblers.}

Size universally small. Bill very slender, distinctly notclied. Feet formed for walking, perching, or climbing. ' larsus sleuder, lengthened.

\section{Surfay. SAXICOLIN\&. Slonechats.}

Bill depressed at the base : gape with diverging bristles. Feet lengthened. 'Tail rather short. Head large.

Griluivora, Sw. Bill strong, lengthened, straight; the base rather widened; the sicles compressed; the culnen slightly curved from the base; the tip of the upper mandible considerably bent over the lower, and deeply notched: gonys ratlier ascending. Nostrils large, naked, sulcated. Wings noderate, rounded; the three first quills graduaterl. Tail more or less lengthened and rounded ; the feathers broad and obtuse at their tips. Feet strong. Middle toe as long as the tarsus; lateral tocs very unequal, the innert shortest; hinder toe shorter than the middle. India, Africa.

G.intermedia. Zool. IIl.ii.61. Iongicauda. O.d'Af.pl.114. brevirnstra. P'art 5. No.85. ? Capensis. Ib. pl. 184. magnirostra. Ib. No. 33. rosea. Part 5. No. 182.

* The first appparance of this excessively rare type strongly reminds us of the genus Indicator, in the shortness of the bill, which is, however, more compressed; and the feet, of course, are quite different. 
'Гнамловия, Sw. Bill small, slender; base widened; the sides much compressed: culmen slightly arched from the base, but the tip of the upper mandible is reflected and entire: gape smooth. Wings short, much rounded; the primaries hardly exceeding the secondaries and tertials, which are very broad. Tail moderate, broad, and much rounded. Tarsus much longer than the middle and hinder toes. Lateral toes very unequal, the inner shortest. Claws slightly curved.

T. leucoptera. O. d'Af. pl. 188.f. 1. atrata. Part 5. No. 36.

SAxicola, Bechstein. Bill broad at the base, compressed on the sides; the tip inflected, and distinctly notchcd. Wings moderate; the first quill spurious; the second slightly shorter than the three next, which are equal, and longest. Tail short, even, or rounded. Tarsi long. Lateral tocs unequal. The Old World.

S. leucoptera, Part 5. No. 37. rufiventer. Part 5. No. 38. rubecola. Selby, pl. 48 . f. 3,4 .

Eпутнаса, Robins. General structure of Saxicola, but the tail more lengthened, the feathers narrowed at their tips, and sometimes mucronate. Rictus with the bristles few, and very weak.

Erythaca, Sw. Wings rounded; the three exterior quills graduated; the first half as long as the second; the third sligltly shorter than the fourth and fifth, which are cqual, and longest. Bill much compressed. Lateral toes nearly equal.

E. rubecola. Selloy, pl. 46. f. 2.

Sialia, Sw. Bill wider at the base. Wings long; the first quill spurious; the sccond slightly shorter than the two next, which are equal and longest. Tarsus moderate, not longer tivan the middle toe. Lateral toes equal.

S Wilsonii. Wils. pl. s. f. 3. Mexicana. N. Z. p. 202. aretica. N. Z. pl. 39.

l'Erroics, Sw. Tip of the bill abruptly deflexed or 
hooked; the notch very distinct: gape strongly bristled. Wings lengthened; the first quill spurious, the second shorter than the third, the fourth longest. Tail moderate, resembling Erythaca. Tarsus moderate. Inner toe much shorter than the outer. Australia.

P. multicolor. Z. Ill. ii. pl. 36 . bicolor. Z. Ill, ii. pl. 4 S.

Suram. PHILOMELINA: Nightingales.

General structure larger and more robust than the typical warblers. Feet formed more for perching.

Pndenicuna, Sw. Redstarts. Bill very straight and slender; the culmen depressed above the nostrils; the gonys ascending; the commissure inflexed: gape ncarly smooth. Wings moderate; the first quill spurious, the second and the eighth equal, the fourth and fifth equal, and longest. Tail broad, slightly rounded. Tarsi lengthened, slender. The lateral tocs almost equal.

P. rutacilla. Selby, 46. f. 3. calliope. Lath. Sup. Vig. Suecica. PI. Enl. 610, f. 1. atrata. 111. Orn. pl. 86.

Phimomeca, Antiq. Nightingnles. Bill rather strong, short; the culmen straight towards the base, and more than usually curved just at the tip: under mandible nearly as thick as the upper; the gonys ascending; the commissure straight, but not infiexed. Wings moderate; the quills straight and narrow; the first quill spurious; the second shorter than the third and fourth, which are the longest. Feet moderate, stout. The inner toe rather the shortest. The claws short, and fully curved.

P. atricapillit. Selby, 46. f. \&. Orphea. Pl. Enl. 579. f. 1. melanoceplaala. In. O.ii.509. sericea. Tem. Man. i. 197. Luscinia. Selby, 46. f. 1 nisorea. Nau. pl. 33. f. 67. germanica. N. pl. 26. f. 52.

Cunruca, Bechst. Resembling Philomela, but the general structurc is more delicate. Bill lengthened, slender; the culnen gently eurved from the base. Wings 
broader ; the shafts curved ; first quill very minute, the second as long as the third. Tail broad, graduated or cuneated. Feet lengthened, slender. The inner toe much shorter than the outer. The claws long, slènder, and but slightly curved.

hortensis. Selby, 46. f. 4. turdoides. Pl. Enl. 513. cinerea. Jb. 46. f. 6. fluviatilis. Tem. Man. i. 183. locustella. Ib. $45^{* *}$. f. 1. aquatica. Nau. pl. 47. f. 106. pluragmitis. It. $4.5^{* *}$. f. 2. palustris. Tem. Man. i. 193. arundinacea. Ib. $45^{* *}$. f. 3.

Branyptetus, Sw. General size and habit of Curuca. The bill distinctly notched. Wings short; the three first quills equally graduated. Tail rounded; the feathers remarkably broad and soft. Feet large, strong, and robust; the lateral toes equal. Claws slender, slightly curved. Africa.

\section{B. platyurus. Ois. d'Af. pl. 122.}

Agrobates, Sw. Bill thrush-like; the sides much compressed; the tip bent and entire: gape smooth. Wings and tail as in Plilomela. Feet very strong. Tarsus lengthened. 'Toes short ; the inner shorter than the outer. Claws slender. South of Europe, Africa.

A. galactotes. Tem. Pl. Col. 251. f. I.

Surans. SYLVIAN无. True Warblers.

Size very small. Structure weak. Bill very slender, straight, and with the under mandible much thinner than the upper.

ORтнотомеs, Horsfield. Bill straight, lengthened; the tip entire; the gonys only lialf the length of the under mandible. Wings excessively short, and rounded; the three first quills equally graduated. Tail typically short, rounded, or graduated. Tarsus lengtliened. Inner toe shorter than the outer. India.

O. longirostris. Pt. 5. No. 183. sphenurus. Ib. No. 184. N.B. Prinia familiaris Horsf. is prohably an aberrant species. MaLuius, Vieill. Bill short. Wings considerably rounded. Tail lengthened, graduated, generally soft. Legs large. 
Hemipteryx, Sw. Bill of Drymoica. Wings excessively short; the tertials as long as the primaries; the first quill minute; the second hardly shorter than the four next, which are equal, and longest. 'Tail very short. Feet as in the next, but the inner toe is longer than the outer. Africa, $3 \mathrm{sp}$.

Le Pinc-pinc. Ois. d'Af. pl. 131.

Drymoica, Sw. Bill entire, short. The rictus bristled. Wings very short, and rounded ; the three first quills equally graduated; the foirth and fifth longest; the primaries hardly longer than the other quills. Legs pale. 'The lateral toes equal. Tail graduated; the feathers obtuse. Africa, South of Europe.

D. cisticola. PI. Col. 6. f.s. Le capocier. O. d'Af. pl. 129. Melizophilus, Leach. Upper mandible distinctly notched; rictus slightly bristled. First quill spurious; the second shorter than the three next, which are the longest. Tail lengthened, rounded; the feathers narrowed towards their tips. Legs moderate. Lateral toes equal. Claws sinall, and slightly curved. Europe.

M. provincialis. Sellyy, pl. 46. f. 6 .

Malurus, Vieillot. Rictus with stiff bristles. Wings short; the first quill half as long as the second; the two next slightly graduated. Tail lengthened, graduated ; the tips broad and truncate. Legs large, long, and slender; inner toe much shortened. Australia only.

M. cyanens. Lath. Gen. Hist. pl. 106.

Sruvis, Latham. Wings long. Claws much curved. Tail moderate, even, or slightly forked.

Sylvia. Tail slightly forked; the feathers not mucronate. Wings long; the first quill minnte, the second and fourth equal, the third longest. Tarsus moderate. The immer toe much shorter than the outer. Europe. S. Hippolaïs. Selby, pl. 47. f. I. trochilus. 1b. pl.47. f.3. Aeanthiza, IIorsfield and Vigors. Wings moderate or lengthened, rounded; the first quill half as long as 
the second, which is shorter than the four next; the third, fourth, and fifth longest, and nearly equal. Tail moderate, either slightly forked, or slightly rounded; the tips sometimes ending in mucronate points. Feet moderate. The inner, toe shortest. Australia.*

A. nana, Lin. Tr. xv. 226.

Regulus, Ray. Tail slightly forked, ending in mucronate points. Wings long; the first quill spurious; the second much shorter than the third, fourth, and fifth. Feet as in Sylvia.

K. auricapillus. Selby, pl, 47. f. 4.

Cyanotis, Sw. Habit of Regulus. Wings slightly rounded; the first and second quill very little shorter than the third. Tail rounded, obtuse. Feet uncommonly large and slender. Inmer toe much shorter than the outer. Claws very long, and but slightly curved.t Brazil.

R. omnicolor. Vieil.

Culicivora, Sw. Bill somewhat lengthened; the base depressed; the sides compressed ; the culmen arched frorn the base; the tip notched. Rictus with distinet bristles. Wings very short; the two first quills only equally graduated. Tail slender, graduated, and generally lengthened. Tarsus long, slender. Inner toe shortest. Claws small, fully curved. America only.

C. atricapilla. Zool. III. ii. pl. 57.

Praticolia, Sw. $\ddagger$ Aspect of Anthus. Culmen not depressed before the nostrils. The upper mandible notched; the margins not inflexed. Frontal feathers

* We may account for the great variation in this very natural group, by supposing it is that which connects Sylvia to Malurus.

$t$ This seems the tropical reprosentation of Regulus: it is at once known by its disproportionutely long toes and claws. It is the Rig. Byronensis of Griff: Cuv.

I Although this extraordinary form has all the aspect of an Anthas, I cannot but think that this is merely its disguise, and that its natural afini. ties are in this group. It has a strong resemblance to Aconthiza, and more to Orthotomus, in its tail and wings. I have therefore placed it as the representation of Anthus in this group, until its affinities are better understood. 
rigid and semi-setaceous. Wings very short and rounded; the two first quills equally graduated; the five next of equal length, and longest. Tail moderate, graduated; the feathers broad, the tips oval. Legs very large and strong. Tarsus and middle toe equal; hinder toe and claw rather shortcr; lateral toes equal. Claws slender, and but slightly curved; hinder claw large, and as long as its toe. Australia.

P. anthoides. Part. 5. No. 185.

\section{Subram. PARIAn 2 . Titmice.}

Bill either entire, or very slightly notched, more or less conic. Tarsus never shorter than the hind toe, which is large and strong. Lateral toes unequal.

Setopiaga, Sw. Bill depressed, resembling that of a Muscicupa. Rictus bristled. Wings moderate, somewhat pointed; the first quill slightly shorter than the second, the third quill longest. Tail somewhat lengthencd, rounded; the feathers terminating in soft points. Tarsus slender, lengthened. (fig. 213,a,b)

S. ruticilla. Wil. pl. 6. f. 6. miniata. Part 5. No. 40. canadensis. Ib. pl. 26. 2. auricapilla. Ib. No. 41. cucullata. Ib. pl. 26. f.3. rufifrons. Ib. No. 42. rubra. Part 5. No. 39.

SylvicoL^, Sw. Fly-catching Warblers. Bill slender, notched a little way from the tip. The rictus weakly bristled. Wings long; the first quill nearly, or fully, as loug as the others. Feet slender.

Dumecola, Sw. $(c, d)$ Bill small, widened at the base; the sides compressed. The first quill, and sometimes the second, slightly shorter than the following. Tail even, or slightly rounded; the tips mucronate. Tarsus longer than the lind toe. Inner toe shortest. D. ruficauda. N. Z. 489 . caniceps. Braz. B. pl. 49. Sylvicola, Sw. Bill very slender, acutely conic; the tip of the upper mandible with an obsolete notch; 

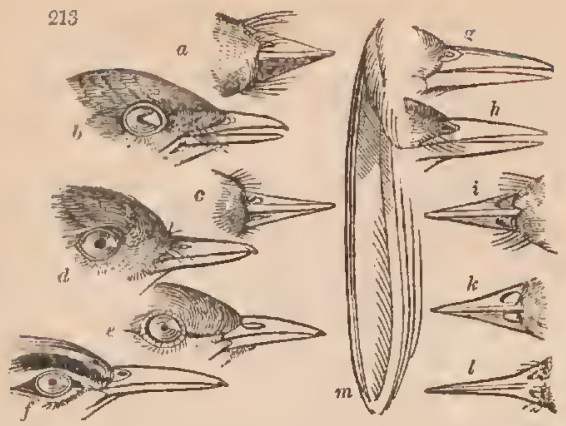

base with a few weak bristles. Wings lengthened, pointed; the three first quills nearly equal. Tail nearly even; the feathers ending in soft points. Feet as in Setophaga. (fig. 213. m. 214. $a, f$ )

S. pusilla. Wil. pl. 38. f. 3. minuta. Z. Ill. i. pl. 139.

Vermivora, Sw. (fig. 213.g) Bill rather lengthened, acutely conic, entire. Wings and tail as in Sylvicola. Middle toe as long as the tarsus; lateral toes slightly unequal. Legs pale.

fulvicapilla. Wil. pl. 24. f.4. (g) pinus. Ib. pl. 19. f.4. $(h, i)$ Mniotilta, Vieillot. $(f, l)$ Bill rather lengthened: culmen slightly arched : gonys straight; the margins inflexed: upper mandible obsoletely notched. Wings lengthened, pointed. Tarsus and middle toe of equal length; inner toe shortest; hinder toe lengthened, nearly as long as the tarsus; its claw much curved.

M. varia. Wilson, pl. 19. f. 3.

Zosterops, Horsficld and Vigors. $(e, k)$ Bill rather stouter than in Sylvicola, acutely conic, almost entire. Rictus smooth. Wings moderate, pointed; the first quill rather shorter than the three next. Tail as in Sylvicola. Feet strong. Tarsus longer than the middle toe; lateral toes unequal. Eyes encircled 
with compact white feathers. India, Africa, and Australia.
Z. dorsalis. Z. Ill. i. 165. Hava. West Af. ii.
pallida. Part 5. No, 43.
cinerea. Part 5. No. 44. ambigua. Ib. No. 45.

PArus, Linnæus. Bill stronger. Wings with the threc first quills graduated. Feetstrong. Inner toe shortest. Claws broad, and much curved.

Ägithina, Vieillot. Bill lengthened, rather stout: culmen very slightly curved; the sides somewhat cylindrical : the upper mandible notehed. Wings

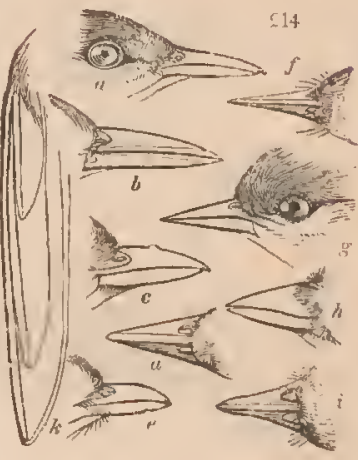
short; the first quill shorter than the second. (Vieillat.) (fig. 214.b)

A. leucoptera. Vieil. Ois. d' $\Lambda$ m. ii. pl. 84.

Egithalus, Vigors. (fig. 214.g) Bill very straight; the form acutely conic; sides compressed; tips entire. Riçtus smooth. Wings short, rounded. Feet robust. Tarsus short. Anterior toes nearly equal.

T. Capensis. Ill. of Orn. iii. pl. 113. f. 1.

Parus, Linn. Bill rather short, strong, conic; the sides compressed; tip entire. Tail rather lengthened, convex, even, or more or less rounded. Feet large and strong. Middle and hinder toes equal; lateral toes unequal. ( $f i g, 214, h, k$ )

P. major. Selb. pl. 51. f. 1. biarmicus, Selb. pl. 51. f. 6 . caudatus. Ib. pl. 51. f. 5 . leucopterus. West. Af. ii.

Parisoma, Sw. Bill very short, straight; sides considerably compressed: upper mandible arched from the base, and notched; lower thick: the gonys 
ascending. Rictus with a few weak bristles. (fig. 214. $e, i)$ Lateral toes equal. Africa.

1. rufiventer. Ois. d'Af. $\mu$ l. 126.

Hylophilus, Temminck. Bill stout, conic: both mandibles of nearly equal thickness; the upper one slightly notched, and both acute: gonys ascending. Wings rather short, rounded. 'Tail modcratc, rounded. Feet as in Parisoma. (fig. $214 . c, d$ ) America.

H. poicilotis. B. 13. ii. 89. f. 1. thoracicus. Ib. ii. f. 2.

Acoentor, Bechstein. Bill rather strong, conic; the base widened, the sides compressed : both mandibles equally thick; the tip of the upper entire; margins inflexed. Wings long, pointed; the first quill hardly shorter tham the second and third, which are the longest. 'Tail slightly forkerl. Feet large, stroug. Tarsus longer than the middle toe, which is shorter than the hinder. Lateral toes almost equal. Europe. A. alpinus. Il. Or. pl. 68. modularis, Selby, 43. f. 4.

Seiurus, Sw. Bill with the upper mandible notcled. Tail even. Middle toe inuch longer than the hinder. America. Annectant to Trichas.

S. auricapillus. Wils, pl. 14. f. 2 . aquaticus. N. Z. pl.49. Tricras, Sw. Bill somewhat conic, compressed; the base a little widened: both mandibles equally thick; the upper very slightly bent and notehed: gonys ascending. Rictus bristled. Wings short; the first and sccond quills slightly graduated. Tail roundcd. Fcet large, slender. Tarsus long. Middle toe shorter than the tarsus; lateral toes equal.

T. personata. W. i. pl. 6. f. 1. superciliosa. Sw.Part 5. No.46. velatit. Zool. Ill, i. pl. 174.

\section{SUBram, MOTACILLINA. Wagtails.}

Bill lengthened; very straight and slender. Legs long, formed for walking. The hind toe much longer than the rest. Wings pointed, Tail narrow, and much lengthened. 
Lessonia, Sw. Bill depressed, resembling that of a flycatcher. Rictus with weak bristles. Wings long, pointer; the first quill scarcely shorter than the second and third, which are the longest. Tail moderate, divaricated or even. Tarsi and toes very long and slender. Lateral toes equal. Claws acute, slightly curved; the hinder much lengthened, and almost straight. South America.

L. erythronotus. Sw. N. Zool. ii. 490. PI. Enl. 738. f. 2.

Budy tes, Cuv. Bill weak and slender; very strait. Gonys slightly ascending: upper mandible notcher. Rictus smooth. Wings pointed; the three first quills nearly equal. Legs large, and very slender. 'Tarsus and middle toe equal. Lateral toes equal, but the inner claw longer than the outer; hind toe as long as the tarsus. All the claws slender, acute, and but slightly curved.

B. flava. Selby, 49. f. 3.

MотаспlLa, Linnaus. Bill, wings, tail, and general structure of Budytes. Middle toe shorter than the tarsus. Lateral toes equal; their claws ncarly so: hinder toe as long as its claw; the latter not lengthened, and only half as long as the tarsus.

M. alba. Selby, pl. 49. f. 1 . boarula. Selby, 49. $\mathrm{f} .2$.

Exrcunus, Temminck. Bill rather strong, lengthened, very straight, abruptly bent, and notehed. Culmen straight from the base. Gonys thickened, ascending. Rictus bristled. Wings rather short; the three first quills graduated. Tail lengthened; deeply forked. Feet strong. Tarsus lengthened; the scales entire. Middle toe shorter than the tarsus; outer toe longest. Legs pale.

E. speciosus. Horsf. Java. Pl. Enl. 113.

Anтиus, Bech. Bill very slender; the sides compressed: the upper mandible longest, with the tip deflexed over that of the lower, and distinctly notched. Wings moderate; the four first quills ncarly equal; tertials obtuse, lengthened. Tail moderate, slightly forked. 
AMPELIDF⿻ - LEIOTRIOHANA. - VIREOIN F. 249

Legs slender, black. Tarsus and middle toc equal. Lateral toes and claws of the same length and sizc.

A. aquaticus. North. Zool. pl. 44.

FAMLY AMPELID现. Fruit_eaters, or Chatterers. Bill short; basc broad; sides compressed; the tip notched and sometimes hooked. The gape very wide, opening beyond the eyes. Fect short, or long and very weak: the tocs morc or less united; the soles flat. Inhabit Tropical Ameriea only.*

SUbast. LEIOT!RICHANA. Sillyy Chatterers. ?

Legs large, robust, syndactyle. Hlind toc longer than the outer. Wings short, and rounded. Bill strong: the gonys ascending.

LeIoThRIX, Sw. ( fig. 215.) Bill much compresscd. Culmen gradually curved. Nostrils large, nembranaceous. Tail moderate, deeply forked.

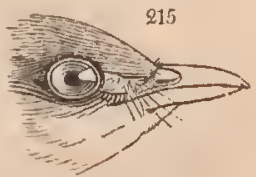

L. furcatus. Pl. Col. 287. f. I. Ludia.

Prerutinus, Sw. (fig. 216.) Bill short, compressed, thick; the tip slirike-like, hooked: culmen arched : gonys ascending. Nostrils basal; the aperture round. Gape wide. Rictus

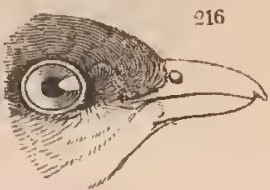
slightly bristled. Wings very short, rounded. Tail short, broad, rounded; the tips obtuse. Tarsi smooth, pale.

P. erythropterus. Gould's Cent. pl. 11. India.

SUnfarr. VIREOINA. Grecnlets and Thickheads.

Bill generally lengthened, moderately strong, eompressed; somewhat shrike-like: the gonys ascending; the tip hooked. Nostrils and mouth with setaceous hairs. Wings more or less pointed. Tail moderatc, even, or

* Excepting Pardalotus, the Leiotrichana, l'achyccphalus, and Calyptomina. 
divaricated. Feet rather strong. Inner toe shortest. Obs. The large species resemble thrushes; the smaller, warblers. The tenuirostral type.
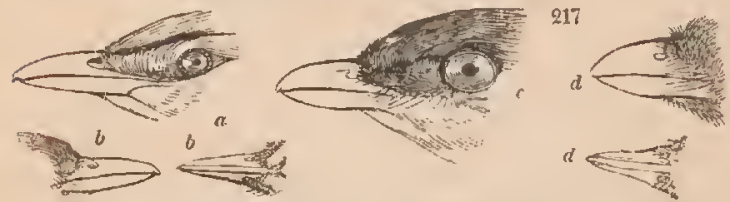

Vireo, Vieil. (fig. 217.a) Greenlets. Sect. 1. Stature small, sylviform. Bill strong, resembling a Myothera; but the base broad. Wings long. Claws large, much curved. Plumage, above, green. $r$.olivaceus.

Sect. 2. Wings shorter; the first quill nearly spurious. Tail rounderl. (b)

V. olivaceus Wils. pl. 12. f. S. $(a)$

Pachycephala, Sw. (fig. 217. c, d) Thickhead. Bill eitlier like $V$ ireo, or short, thick, and somewhat conic. Rictus strongly bristled. Under mandible strong. Wings moderate: the three first quills graduated. Tail broad, cven, mucronate. Feet strong. The outer toe connected as far as the first joint; inner toe short. Anterior scales divided; lateral entire. Australia only.

P. fusca. Lin. Tr. xv. 240. (c)

Eopsaltria, Sw. (fig.218.) Bill as in Pachyccphula, but more lengthened, straight; the tip abruptly hooked. Gonys straight. 'The rictus slightly

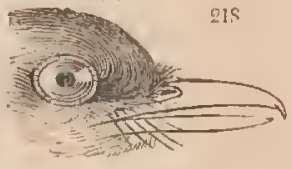
bristled. Wings rather lengthened. Legs slender. 'Tocs long. Tail divaricated. Australia 1.

E. flavicollis. Lewin, pl. 23.

Pruconlonis, Sw. Lunet. Bill as in Vireo (Sect. 1.). The front, nostrils, and rictus strongly bristled. Wings long; the third quill longest. Tail rather short, slightly rounded; the feathers mucronate: tarsi moderate, longer than the hind toe. Toes subsyn- 
daetyle: lateral toes nearly equal ; middle toe shorter than the hallux. Claws fully eurved.

P. lunatus. North. Zool. ii. p. 492 . Braz. B. pl. 95.

\section{Surfam. BOMBYCILLIN 疋. Swallow Chatterers.}

Wings muel lengthened and pointed; the first quill equal, or nearly so, to any of the others. Bill short, strong, broad: under mandible strong: the gonys aseending: gape smooth, very wide. Nostrils partly protected by velvety feathers. Feet robust. Tarsi short. Lateral toes nearly equal. Phibalura, Vieil. ( $f i g$. 219, 220.c) Bill remarkably short, but rather strong. Culmen arched. Nostrils conceal-

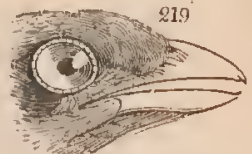
ed. Gape enormous; the sides smooth. Feet pale. Anterior scales transverse; lateral seales minute, reticulate. 'Tail lengthenerl, decply forked.

P. cristata. \%ool. 111. i. pl. 31.

Bомвуеццц, Briss. (fig. 220. a) Plumage soft, silky. Wings loug ; the greater quills graduated from the first; the lesser nearly of equal length. Tarsi feathered below the knees. Hind claw shorter than the lateral toes, which are nearly even. 'Tail short, even.

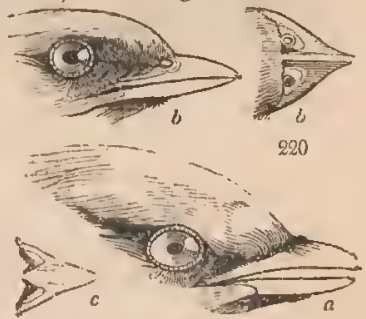

B. garrula. Selby, i. pl. 34.*

Proontas, Hoff. ( $f g .220, b$ ) Bill very broad; the sides infleeted; the tip not hooked. Nostrils nearly naked. Wings pointed; the three first quills longest. Inner toe shorter than the outer. Tail slightly forked.

P. ventralis, Zool. Ill. i. pl. 21.

* In colour, and in the iunate marks upon the breast, this species closely resembles Btcchropus. 
Subam. AMPELIN A. The Typical Chatterers. Middle-sized. Feet short, robust. Bill weak; the gonyx not ascending. Nostrils large, membranaceous; the aperture terminal. Rictus smooth. Soles of the feet broad, flat. Lateral toes unequal; outer connected to the middle. Lateral scales of the tarsus numerous, small, reticulate. Wings moderate, ample; the first quill shorter than tlie second.

Caly ptomina, Raffles, (fig.221. $a, b$ ) Bill nearly hid by an erect compressed crest, lying over the basc; the
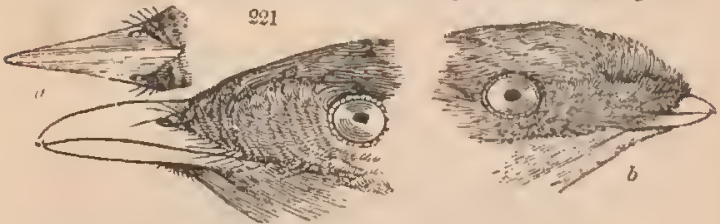

tip hooked. Wings large, very broad ; the first quill shortest, the third longest; the lesser quills emarginate at their tips. Tail very short. Feet short. Hinder toe as long as the tarsus; outer and middle toe connected as far as the second joint.

C. Rafflesia. Sw. PI. Col. 216. caudacuta. Part 5. No. 50. Chrysopteryx, Sw. (fig. 221.a) Size large. Bill lengthened, strong, thrush-like, the sides inflected. Culmen elevated and arched. Gonys not short, inclining upwards. Nostril defended by short weak bristles. Wings and feet as in Casmorhynchus. Tail longer, broad, and even at the ends.

C. erythrorhynchus. Sw. N. Zool. p. 492.

Casmorhyncius, Tem. ( fig. 222. a) Size large. Face
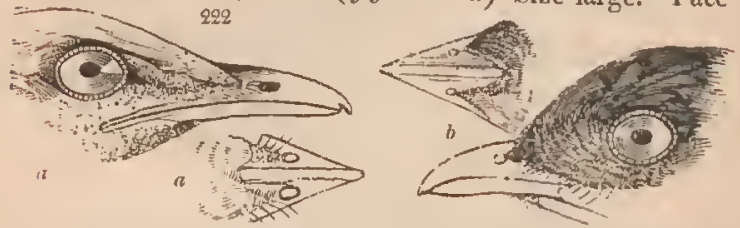

and throat frequently bare of feathers, covered with 
a naked skin, or furnished with wattles. Bill very wide at the base ; the horny portion very short: under mandibte weak, the gonys remarkably short. Nostrils naked, very large, medial between the front and the tip of the bill. First and second quill short, third quill longest. Tail short.

$$
\text { C. nudicollis. PI. Col. } 968.389 .(a)
$$

AMpeirs, Linn. (fig.223.) Plumage brilliant, glossy. Nostrils partly covercd by setaceous feathers. Wings ample; the first quill hardly shorter than

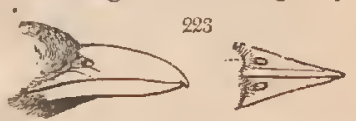
the thrce next. Tail short. Lateral toes almost equal.

\section{A. Cayana. PI. Enl. 624.}

Sect. 2. Smaller. Head feathered. Nostrils plumed. Tail longer. (fig. 222. b)

P. melanocephalus. Z. I. j. pl. 25. cucullatus. Z. I. j. pl. 37.

Rupicola, Briss. Head with an elevated compressed crest, advancing on the front, and partly concealing bill. Bill strong, robust. Feet large, strong. Tarsus partly covered with feathers. Toes syndactyle : outer toe connected to the middle toe beyond its second joint. Wings short, rounded.

R. Cayana. P1. Enl. 39. Peruviana. Pl. Enl. 745.

Subram. PIPRINE. Manakins. Subtypical,

Size small. Fcet lengthened, slender, weak. Bill very short: the upper mandible much curved.

Phomacirous, Sw. (fig. 224.) Size and habit of Ampelis. Bill small, rather wcak. Wings very short, convex, rounded; the three first quills narrow, and of equal length; the fourth much shorter, and ending in a point. Tail broak, evell. Feet short, strong. Toes syn-

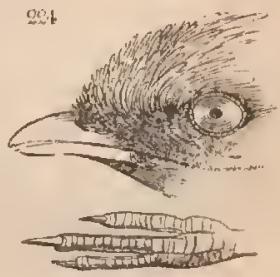


dactyle. Tarsi feathered, on their inner sidc only, as far as the toes. Claws strong, curved.

P. carnifex. Edwards, 1. 59. militaris? O.d'Amer. pl. 25. nigricollis. Spix, ii. pl. 5.

Prpra, Lin. ('fig. 225.) Manukins. Size very sinall. Bill weak: the upper inandible bent over the lower, which is flattened and nearly straight: notch

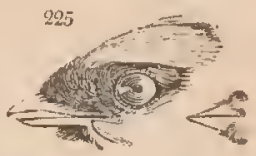
simall. Wings more or less rounded. Tail short, even. Toes syndactyle.

P. strigilata. Brazil. Birds, w1. 25.

Metopia, Sw. (fig. 226.) Front with an elevated compressed crest. Wings lengthened, very broad. Tail broad, lcngthened, rounded.

M. galeita. Braz. B. i. pl. 23.

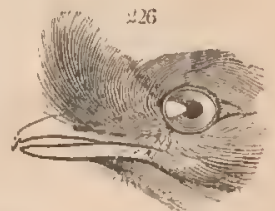

Calyptura, Sw. Bill short, strong, robust, shrikelike; the sides somewhat gibbous: the notch deep and tooth-like. Uncler mandible strong. Wings short, rounded. 'Tail remarkably small, almost concealed. Feet lengthened, slender; toes syndactyle: Brazil, 1 .

C. cristata. Brazil. Birds, pll. 24.

Pardalotus, Vieil. ( $f$ ig. 227.) Billas in Calyptura. Wings long, pointed ; the three first quills of equal length. Tail short, cven. Feet strong; lateral toes free and equal. Australia, 3.

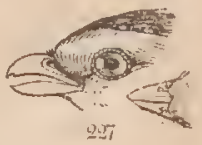
P. punctatus. Pl. Col. 78 .

Family MUSCICAPIDAE. Flycutclers.

Stature small. Bill considerably depressed its entire length, broad: the clge of the upper inandible folding over that of the lower; the tip abruptly bent and notched. Rictus wide, defended with strong rigid bristles 
pointing forwards. Feet almost always short*, small, and weak. Feed solely upon insects captured during flight. Habits sedentary.

\section{Surfam. QUERULIN AE.}

Bill strong, broad, mueh depressed; gape wide. Rictus with strong bristles. Feet short, resembling those of the typical Ampelina. Lateral scales minute.

Querurs, Vieil. Bill large, broad, strong. Gonys long, straight. Nostrils concealed by incumbent reflected feathers. Wings long, broad; the fourth quill longest. Toes unequal; inner toe shortest, of equal length with the hind toe. Tail even.

Q. rubricollis. Vieil. Gal. pl. 115.

Laturis, Sw. Bill weaker. Gonys short, straight. Nostrils large ; the opening apparent, but defended with setaceons bristles. Wings moderate; the quills narrow. Feet weak. Iateral toes equal. In general structure closely resembling the tyrants, except in the feet, mouth, and bill. Brazil, 3 sp.

\section{I. cincrea. Le Vieil. Am. pl. 44.}

SURAM. PSARIANR. Black-Caps.

Bill large, thick, subcylindrical. Culmen convex, and without any ridge; the tip abruptly bent and notched. Head large, depressed. Mouth very wide. Feet weak: Lateral toes unequal. Anterior scales of the tarsi trans. verse; lateral scales small, numerous. Wings long.

PSaris, Cuv. Bill large. The rictus smooth, often naked round the cyc. Wings lengthened; the first quill equal, or longer than the fourth. Tail short, even. Inner toe shorter than the outer.

P. Cayanensis. 11. Enl. 377 semifusciatus. Ill. of Orn. erythrogenis. 1. O. i. 10. Guianensis. Part 5. No.17. Braziliensis. Jb. No. 18. Natterii. Ib. No. 19. Jardinii. Z. III. ii. pl. 35. cristatus. Ib. ii. 41. strigatus. Part 5. No. 21. Selbii. Ib. No. 20.

Pacexrnyenus, Spix. Stature smaller. Wings more

* Except in the rasorial types, where of course they are longer. 
rounded; the first quill shorter than the fourtl. Tail lengthened, rounded. Lateral toes equal. Brazil.

P. Cuvieri. Zool. Ill. i. 32 . pectoralis. Part 5. No. 25. castaneus. I.O.pl,10.f.1. leucogaster. Ib. No. 26. megacephalus. Part 5. albifrons. Ib. No. 27.

No. 22.

ruficeps. Ib. No. 24.

Spixii. Ib. No. 28.

niger. Ib. No. 29.

SunfaM. FLUVICOLIN F. Water-Chats.

Legs formed for walking. Tarsi lengthened, strong. Inhabit the sides of marshes and rivers in Tropical America. Seisura, alone, is Australian.

Guberneres, Vigors. Tail very long, excessively forked; the first quill nearly as long as the three next. Lateral tocs equal. Claws long, acute, and slightly curved.

G. forficatus. Zool. Journal, ii. pl. 4.

Arectunus, Vieil. Tail compressed on the sides, erect, broad, with the shafts of some of the feathers naked and lengthened. Head very large. Bill short, strong, triangular, depressed, without a culmen. Feet large. Wings roundcd.

\section{A. psalurus. Pl. Col. 286}

Fuuvrcola, Sw. Bill somewhat lengthened, sinooth and convex above, generally without any culmen. Feet strong, large; the transverse anterior scales enveloping the tarsus. Wings long, pointel; the second quill longest. Tail even or rounded. Plumage varied with black and white.

F. cursoria. Sw. Zool. Ill. ii. pl. 47.

Blechropus, Sw. Bill short, triaugular, somewhat conic, but repressed. Culmen obsolete. Nostrils round, pierced in the substance of the bill. Wings moderate; the third quill longest. Feet small, weak. N. B. The bill much resembles that of Pachycephala. Plumage more or less black. Pepoaza Azara.

No species figured.

Sersura, H. and V. Bill lengthened, much depressed, 
with an elevated straight eulmen; near the tip eompressed. Wings long; the first quill spurious; the fourth and fiftl longest. Tail lengthened; the sides rounded. Feet moderate, slender, resembling those of Muscipeta. Inner toe shortest; outer toe conneeted to the middle at the base. Crape with short bristles. Australia.

S. volitans. Xin. Tr.xv. 250

Perspicicla, Sw. Bill long, compressed on the sides. Nostrils uaked. Wings rounded, broad; the scapular quills as long as the primary quills. Tarsi very long, smooth. Tail rather short. S. America.

1. leucoptera. Sw. See cut in Vol. 1. p. 30.

Surram. :MUSCICAPINT. Flycalchers.

Feet weak, formed only for perching, generally short (exeept in Tolus), but always very slender, and often syndaetyle. Bill more or less depressed. Grape with stiff bristles. Claws small, considerably curved. Lateral toes unequal. Inhabits warm and tropieal latitudes; but exeluded from North Ameriea.

Rhipidura, Horsfield and Vigors. Meal very large. 'Tail long, broad, fall-shaped, mucli rounded. Bill small, short, the sides considerably compressed: the bristles of the gape as long, and sometimes longer, than the bill. Wings moderate; the first quill spurious, half as long as the sccond; fourth and fifth longest. Feet slender. Australia, Java, and Indian lslands.

R. Alabellifera. Lin. Tr. xv. 247.

Monacina, H. and V. Bill large, thick. Culmen elevated, and curved from the base; the tip abruptly hooked and strongly notched: under mandible thick, with the gonys aseencling. Gape strongly bristled.

M. carinata. Z, 1. i. pl. 147. niger. Pl. Col. 480. f. 1. velata. Pl. Col, 337. cincrascens. 11. 430. f. 2. Voy. pl. 18. f. 1. trivergata. Ib. 418. f. 1. chrysonela. Ib. pl. 18. f. 2. Megalophus, Sw. IBill large, very thin, wide towards VoL. II. 
the base. Culmen depressed jits whole length; tip abruptly hooked. Feet pale.

M. regius. Braz. Birds, ii. pl. 51, 52.

Tonus. (fig. 228.) Feet very weak. Tarsi lengthened, slender, considerably longer than the hind toe and claw. Anterior toes short; lateral toes unequal, more or less uniterl at their base. Bill broad, typically lengthened, boat_shaped, thin, contracting suddenly at the tip, which is gradually hooked. Wings and tail very short, rounded; the latter very slender. The following appear to be subgenerie types.

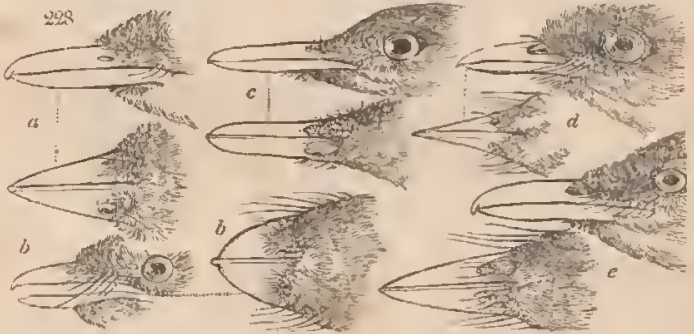

Conopophaga, Vieil. (fig. 228. $a$ ) Head very large. Tail excessively short. Bill short, gradually narrowing to the tip. Gronys ascending : front with setaceous plumes, but without bristles. Feet and toes long and slender; the inner shortest; the outer united as far as the first joint.

C. ruficeps. B. B. ii. pl. 72. collaris. B. B. ii. pl. 74.

Platyrhynchus, Desm. (fig. 228. b) Bill very short, broad, and weak; the sides dilated: under mandible very weak and flat. Bristles at the gape longer than the bill. Tail and wings as in Conopophage. Feet small. Tarsi and toes very slender; the latter short and syndactyle; lateral toes unequal.

Todus, Lin. (fig. 228. c) Bill lengthened, broad throughout, contracting surldenly at the tip, very flat. Bristles short, weak, or none. Tail short, very slenter. rounded. Legs long, weak. Toes short; the 
outer more or less united to the middle toe. Tropical America only.

T. viridis. Jin. Zool. Ill. ii. pl. 66.

Lepturus, Sw. (fig. 228. $d$ ) Bill triangular, gradually narrowed from the base, culminated. Wings excessively small, and very much rounded; the lesser quills being nearly as long as the primaries. Tail lengthened, very slender. Feet large, much developed. Claws slender, and but slightly curved.

L. fulviceps. Braz. Birds.

Platystera, Jard. Selby. (fig. 228.e) Bill somewhat lengthened, boat-shaped: culmen sharp. Wings moderate, rounded; the first quill almost spurious. Tail broad, short; the sides rounded. Tarsi lengthened. Africa only.

P. lobata. Ill, of Orn. i, pl. 9.

Muscicara, Linn, (fig. 229.) Feet very small. Tarsi short, not mueh longer than the hind toe and claw (except in Mrecicnpa proper). Bill broad at the base, gradually narrowing towards the tip, where it is compressed on the sides; the tip abruptly hooked. Wings and tail somewhat lengthened and rounded, but both fully developed; the first quill of the wing is always spurious.

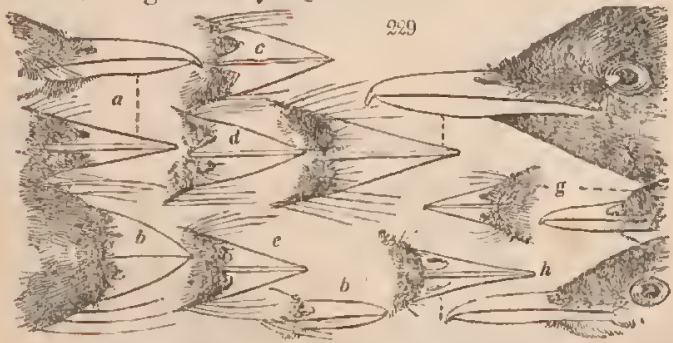

* Cryptolopha, Sw. (fig. 229.a) Bill short, triangular, resembling that of Lepturus. Rictus with lengthened

* We propose substituting this name for Seicircus, used in the former part of this volume, to avold any confusion of this group with those of Seistura and Seiurus. 
bristles. Wings moderate; the first quill short, spurious, and only half as long as the second; the third shorter than the fourth. Tail moderate, rounded; the tips suldenly narrowerl and mucronate. Tarsus lengthened, slender, nearly twice the length of the hind toe. Lateral scales entire. India only?

C. auricapilla. Part 5. No. 186.

Muscipetn, Cuv. ( (fo. 229.f) Bill large, rather lengthened, broad at the base, and gradually narrowed to the tip. Feet short, weak. Lateral toes unequal. Wings moderate; the three first quills graduated. Tail rather long, rounded, graduated, or cuneated.

M. rufiventer. West. Af. ii. Puradisea. Auct.

Myäagra, Horsf. Vig. (fig. 229. b, c, d, e) Bill large, short, broad, sudilenly narrowed at the tip. Wings and feet as in Muscipeta. 'Tail moderate, even.

M. plumbea. Lin. Tr. xv. 254.

Muteicupa, Lin. (fig. 229.g) Bill smaller, triangular, and not much dilated at the base. Wings more pointed ; the first quill very small and spurious; the second not much shorter than the third and fourth, which are the longest. 'Tail rather short or inoderate, even, or slightly forked. Feet stronger than in the two preceding types. The tarsus and the middle toe lengthened; inner toe almost as long as the onter.

M. grisola. Selby, 49*. f. 1.(g) luctuosa. Selby, 43*. f. $2,3$. IIyliota, Sw. (fig. 229.h) Bill lengthened, very slightly widlened at the base, and much compressed beyond the nostrils. Rictus nearly smooth. Wings, tail, and feet as in Muscicapa; but the midlle toe is shorter, and the claws are broader, thicker, and much more curved. $\Lambda$ frica : representing Platystera.

H. flavigaster. West. Af. ii.

Surfam. EURYLAIMINAE. Broad-Bills.

Size large. Structure powerful. Bill short, excessively broad: the upper mandible convex above, dilated at 
its base, and the margins folding over those of the under mandible: the tip abruptly hooked. Wings rather short. Fect strong, moderate. The outer toe connected for half its length to the middle toe; hinder toe long; inner toe shortest.

Euny Lainus, Horsf. (fig.14.4.p.81.) Bill broader than the head: under manulible very thin, particularly at the base. Nostrils basal, transverse, oval; the aperture naked. First quill slightly, second almost imperceptibly, graduated. Tail short, rounded. The pre-eminent type.

E. Horsfieldi. 11. Cul. 130, 31. Sumatranus. 1b. 297. ochromalus. Ib. 261.

Cymbiryncuus, Vigors. Bill thicker, subconic, and more powerful; the hase with a thickened margin: under mandible strong, equally deep with the upper. Gonys angulated and aseending. Nostrils naked, placed in the middle of the bill. Tail rather lengthened, graduated. The sulbtypical type.
C. nasutus. Pl. Col. 154.

Platystomes, Sw.* Bill as broad as the head; the base encircled by a thickened margin: the cutting edge of the upper mandible not dilated or folding over that of the under. Rictus strongly bristled. Nostrils basal, oblong, naked, and without a membrane. Wings lengthened, pointed; the outer quills graduated; the fourth and fifth quills equal, and longest. 'Tuil moderate, forked. Feet as in Eurylaimus, but the tarsus is shorter. The fissirostral type.

P. Blainvillii. Less. Voy. Coq. pl. 19. f. 2.

Psarisonus, Sw. $\dagger$ General structure of Eurylaimus; but the bill is small, and only of an ordinary size. Tail rather lengthened.

P. Dalhousix. Wilson. Ill. of Zool. ?

* M. Lesson places this and Cymbirynchus, in his genus Erolla.

+ Never having seen a kpecimen, 1 ean only judge of this remarkable type by the figure in Dr. Royle's work on Ilymalayan Natural History. Its striking resemblance to a Psnris, and the smalluess of its bill, makes me conclude it is the most aberrant, or tenuirostral type. 
Serrophus, Sw. Bill smaller. Head with a procumbent crest of silky feathers. Nostrils as in Eurylaimus. Rictus smooth. Wings moderate; lesser quills emarginate at the tips. Tail short, rounded; the tips of the feathers, together with those of the four first primaries, terminated in soft slender points. The rasorial type.*

S. lunulatus. Zool.. Tr, i. pl., 25.

Tribe II. CONIROSTRES.

Bill more or less conic; slightly notched.

Famir CORVIDAE. Crows.

Size large. Bill thick, strong; the upper mandible with a very slight notch. Nostrils eovered or defended by incumbent bristles ar feathers. Feet strong.

Subram. CORVIN A. Typical Crows.

Stature large. Form robust. Feet formed for walking : the lateral toes of equal length. Wings lengthened, pointed.

Corvus, Linn. Bill somewhat lengthened, strong: tip of the upper mandible slightly inflexed over the lower; obsoletely, or not at all notched: culmenelevatcd, and slightly curved from the base. Nostrils

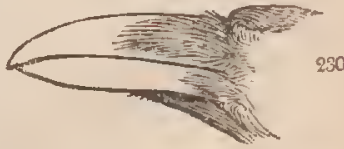
covered and concealed by stiff, lengthened, incumbent bristles. Wings long, pointed; the first, second, and third quills graduated. Tail various.

$$
\text { C. corone. Selby, pl. } 28 .
$$

Pica. Brisson. Magpie. Tail lengthened, and considerably graduated.

Corvus pica. Selby, pl. 31. f. 2.

- It is by this beautiful type, and Megalaphus regius, that I consider the Eurylaimino and the Muscicapince are united. 
Nucifraga. Brisson. Nutcracker. Bill perfectly straight, and conic; the base dilated, and dividing the frontal feathers.

guttata. Vieil. Selby, pl. 33 *. hemispila. Gould, C. pl.36.

Barita, Cuv. Shrike-Crows. Bill very straight, compressed, lengthened; the culmen not curved; the tip

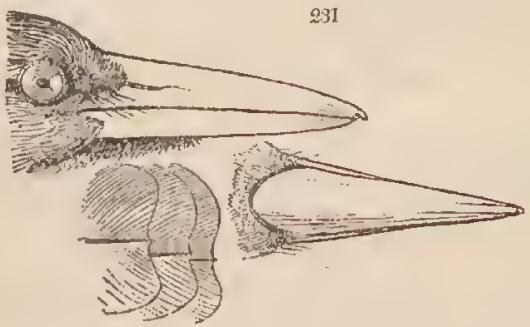

only bent down, with a distinct notch or tooth in the upper mandible. Frontal base of the bill thick, broad, and dividing the frontal feathers. Nostrils naked, linear, pierced in the solid substance of the bill. Outer toe connected to the middle nearly as far as the first joint. Fcet strong, robust, formed for walking. Latcral toes almost equal.

Tibicen. Freyc. Voy, pl.20. graculina. White, Voy. pl.36.

Vanga, Buffon. Tip of the upper mandible forming an abrupt hook, and armed with a prominent tooth. Rictus strongly bristled. Wings pointed; the two first quills graduated; the primaries considerably longer than the secondaries and tertials. Tarsi rather short. Middle and linder toe of equal length; inner toe much shorter than the outer, which is connected to the middlc toe. Claws much curved, very acute. Tail even.

V. destructor. Tem. Pl. Col. 273.

Platylophus, Sw. Bill intermediate in form between Vanga and Garrulus. Culmen slightly curved: gonys 
ascending, curved. Front of the head and nostrils defended with stiff setaceous feathers. Nostrils oval, basal. Rictus bearded. Wings rounded; the primaries not much longer than the scapulars. Tail rounded, terminating in setaceous points. Feet moderate. Hinder toe and claw very strong; longer than the middle, which is short; lateral toes equal. Claws acute.

\section{P. galericulatus, N. Zool. ii. 482.}

Phonygama, Lcsson ( $f i g$. 232.) Bill large, strong, considerahly compressed ; very high at the base, gradually narrowing towards the eud; the front advancing on the crown of the head, and considerably dividing the frontal plumes: upper mandible distinctly notched. (a) Nostrils very large, placed in a deep de-

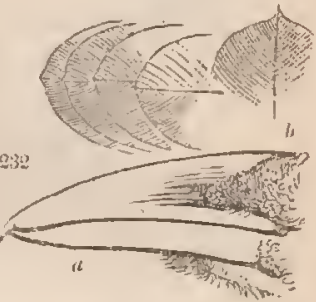
pression of the bill; the aperture large, oval. Frontal feathers short, reflected forwards. Wings __? Tail moderate, rounded; the feathers broad, truncate, and ending in setacious points. (b)

P. Lessonia. Less. Voy. pl. 13. chalybea. PI. Enl. 634.

\section{Surfar. GARRULIN 2 . Jays.}

Stature smaller. Structure less robust. Feet formed for grasping. The lateral toes unequal. Wings shorter, more rounded. Colours bright.

Gannouus, Willughby. (fig. 233.) Bill with the gonys as much curved towards the tip as is the culmen; commissure straight. 'Tip of the upper mandible distinctly notched, and rather

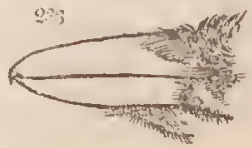
suddenly bent over the lower. Nostrils hidden by incumbent bristles. Wings moderate, rounded; the 
four first quills graduated. Tail rouniled; the tips mucronate. Legs moderate; the inner toe and claw shorter than the outcr.

G. glandarius. Selby, pl, 32. lanceolatus. Gould's Cent. bispecularis. It. p. 38 . pl. 39.

Cyanurus, Sw. (fig. 234.) Feet black, and very large. The latcral toes typically equal. Nostrils partially hid by the frontal plumes, which are directed forwards. Bill crow-like; tle

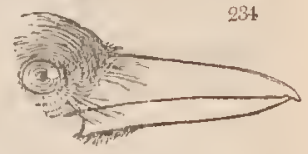
notch almost or quite obsolete on the upper mandible, and the tip not suddenly bent over the lower. Culmen more arched than the gonys; commissure curved. Wings and tail rounded; the tips of the latter not mucronated.

cristatus. Wilson, pl.1. f.1. Stelleri. N. Zool, ii. pl.54. sordidus. Zool. Ill.ii. pl.86. cristatellus. PI. Col. 193. erythrorynchus. Gould's Cent. pl. 41.
Floridanus. Bon. Am. Orn. coronatus. Ill. of Orn. 64 . cyanopogon. Pl. Col. 169. pileatus. Ib. 58. azureus. Ib. 168. formosus. Ib. 436 .

Dysorniturs, Sw. Bill very short, conic; the base wide, the sides compressed, the tip slightly bent and notched. Gonys ascending. Rictus with stiff bristles, half the length of the bill. Nostrils concealed by incumbent feathers. Tail moderate, graduated. Tarsi moderatc. Inner toe shortest. Claw of the hind toe but slightly curved. Feathers of the back very long and soft.

D. Canadensis. Wilson, 20. f.1. brachyrynchus. N.Zool.ii. infaustus. M. Carls. pl. $76 . \quad$ pl. 55.

\section{Subam. GLAUCOPINIE. Wattle Crows.}

Bill short; the culmen elevated, and curved from the base; the upper mandible entire; the gonys straight; the commissure considerably curved. Rictus smooth. Wings short, rounded. Tail lengthened, graduated, or cuneated. 
Crypsirina, Vieillot. ( $f g .235$. ) Bill shorter than the head, much compressed; the culmen considerably arched, and curved from the base. Nostrils small, basal, concealed by incum-

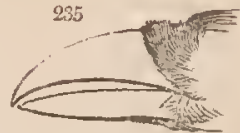
bcut feathers, which are either soft or setaceous. Wings short, much rounded; the primaries hardly longer than tlie secondaries. Tail feathers broad and obtuse. Feet noderate, arboreal. The middle toe and claw short, but as long as the tarsus ; lateral toes unequal; lind toe and claw slıorter than the tarsus. India. rufa. Ois. d'Af. pl. 59. vagabonda. Gould's Cent. leucoptera. Pl. Col. 265. pl. 42. temnura. Ib. 337.

Sinensis. Gould, C. pl. 43. leucogastra. Zool. Tr. pl.12. temia. V. G. pl.106. (fig. 235.)

Pricostonus, Sw. Bill as in Crypsirina. Rictus hristled. Wings morlerate, slightly rounded; the third, fourth, and fifth quills longest. Tail long, cuneated; the feathers lanceolate. Feet very strong and robust. Tarsus lengthened, longer than the middle toe and claw: lateral toes short, and of equal length. $\Lambda$ frica.

P. Senegalensis. West. Af. i. p. 135. Ois. d'Af. pl. 54.

Braorystoma, Sw. (fig. 236.) Bill very short, entire, resembling Glaucopis: the culmen elevated, convex, and considerably dividing the frontal feathers: commissure curved, and somewhat angulated in the middle : under mandible slightly ascending. Nostrils basal, naked; the aperture large and round. Wings and tail moderate, rounded; the latter with broal obtuse feathers. Feet arbo-

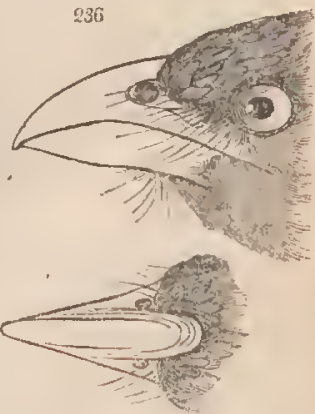
real: the middle toe much shorter than the tarsus, 
and but slightly longer than the hind toe; lateral toes unequal, the inner shortest. Claws strong, and much curved. Australia.

\section{B. cinerea. Part 5. No. 51.}

Guaucopis, Forster. Bill short, strong, robust: the culmen elevated and curved from the base: upper mandible destitute of a notch; under mandible straight (on the gonys), the margin covered by that of the upper, and furnished at the base with two fleshy wattles. Nostrils basal, lateral, partly closed by a large membranc. Feet very strong, formed for walking. The tarsus longer than the middle toe : lateral toes short, of equal length, and divided to their base; hind toe strong, armed with long curved claw. Wings short. Tail rather lengthened, rounded; the feathers ending in setaceous points.* Pacific Islands.

\section{G. cinerea. Gm. Voy. Astrolobe. Ois. pl. 15.}

\section{SubFam. CORACINÆE. Fruit Crows.}

Bill thick, strong, hard, angulated, straight, depressed and widened at its base, compressed beyond: the culmen slightly bent towards the end: the tip of the upper mandible slightly, or not at all notched; inferior mandible with the gonys straight and flattened. Gape with a few strong bristles. Nostrils basal, round, open in front, and either partially or entirely covered with feathers dirccted forwarls. Fect short, strong, arboreal. The tarsus shorter than the middle toe: the three anterior tocs nearly of the same length; the lateral ones slightly connected at their base to the middle toe. Wings long; the third, fourth, and fifth quills longest. Tail short. South America only.

Conacrina, Vieillot. (fig. 237. $a, b$ ) Front and base of the bill protected by short thick-set feathers.

$$
\text { C. scutata. Pl. Col. } 40 \text {. }
$$

* Some of these characters, not inserted in my own notes, rest on the authority of the Manuel d'Ornith. B. Analyse, p. 51 . 


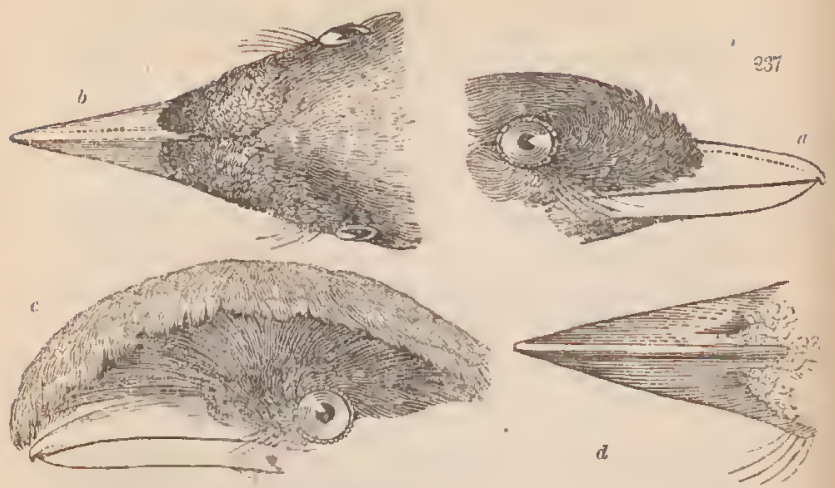

Cepraloptenus, Geoffroy St. Hilaire. (fig. 237. c) General structure of Coracina, but with an enlarged crest on the head, which advances in front, and overshadows the bill.

C. ornatus, PI. Col. 255.

Gxmoceprulus, Greoff. ( fig. 237. d) Head and base of the bill entirely naked.

G. calvus. Le Vaill. Ois. de l'Am. pl. 49.

\section{Surfan. FRIGILINIE. *}

Bill rather lengthened, slender, tapering to a point, subfalcate, and more or less arched. Notch of the upper mandible obsolete. Nostrils basal, lateral, oval, open, entirely concealed by having the frontal feathers

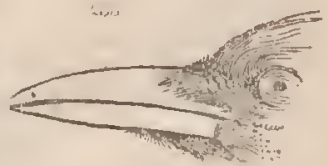
directed forwards. Feet strong, robust. The length of the tarsus variable. Wings long, somewhat pointed; but the three first quills graduated; the fourth and fifth being longest.

F. pyrrhocorax. PI. Enl, 531. erythropus. P1, Eul, 255.

* This subfamily nt present contains but two European birds, which almost appear to be types of as many genera; the above characters are more strictly applicable to the first. 


\section{Family STURNIDÆ. Starlings.}

Size smaller. Stature less robust. Bill angulated at the base; the upper mandible entire. Lateral toes equal.

SUBFam. STURNINR. Typiral starlings.

Bill in the form of a lengthened cone; longer than the hearl : the commissure with an acute angle at the base.

Sturnus, Lin. Bill depressed from the base as far as the tip, which is slightly inflexerl, and obsoletely notched.

Culmen convex and rounderl. Wings lengthened, pointed; the first quill minute and spurious; the second and third longest. Tail short, divaricated. Fect moderate, teirestrial. 'I'he lateral toes equal; the niiddle toe as long as the tarsus; hinder toe shorter. The conirostral type.

S. vulgaris. Selby, pl. 36. f. 1.

PAston, Temminck. (fig.239.a) Bill depressed only at the base, compressed beyond ; culmen slightly bent. Tip of the upper mandible decply notched. Commissure distinctly angulated at the base. Nostrils large, featherer. IVings moderate in length, anple in breadth ; first quill

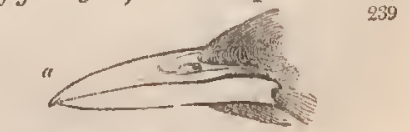
very mimute; the second nearly equal to the third. Tail short, broad, roumled. Feet very large and strong. Midule toe as long as the tarsus; hinder shorter; lateral toes cqual. Claws somewhat slender, acute, but not much curved. Warm latitudes of the old World. The dentirostral type.

P. roseus. Selby, pl. 36. f. 2.

Gracura, Auct. Bill short, stout, not so long as the 
head ; entirely compressed. Frontal feathers advancing far upon the base, but not dividing the front. Cul-. men gradually curved from the base to the tip, which is distinctly

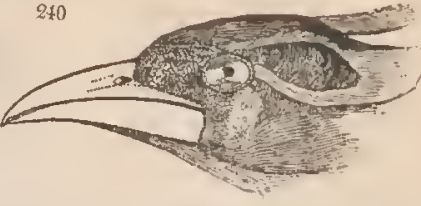
notehed. Commissure but slightly angulated. Under nandible with the base broad and dilaterl. Nostrils basal, naked, round, sunk in a depression. Frontal featlers short, velvety. Hcad with naked wattles. Wings as in Pastor. Tail short, even. Feet rather short, very strong. Tarsus and middle toe equal; linder toe shorter; inner toe almost equal to the outcr toe. India. The fissirostral type.

G. religiosa. Pl. Lnl. 268. Dumonti. Lesson. Voy. pl. 26. Acrimothelks, Vicill. General strueture of Pastor; but the whole of the head is entirely naked, and furnished with fleshy crests and wattles. Nostrils large, naked. Fect moderate. Tail even. Bill very wide at the base. (fig. 239. b, c) The tenuirostral type.
A. carunculitus.
O. d'Af. pl. 93, 94 .

Oxystonus, Sw. Bill much lengthened, longer than the head; the sides eompressed. Culmen flattened, nearly straight, and augulated on eaeh side ; the base advaneing very far upon the head, and dividing the frontal feathers. Nostrils placed in a large depression towards the base of the bill. Wings very short, and considerably rounded. Tail moderate, rounded; all the feathers, and the secondary quills, ending in setaceous points. Legs long, and robust. Tarsus much longer than the inisldle toe: lateral toes unequal, the inner shortest. Pacific Islands. The seansorial type.

O. carunculatus. Lath. G. Hlist. pl. 79.

Sunfar. LAMPROTORNIN J. Grakles.

Bill thrush-like, compressed; the culmen curved from the base. Lateral tóes unequal. 

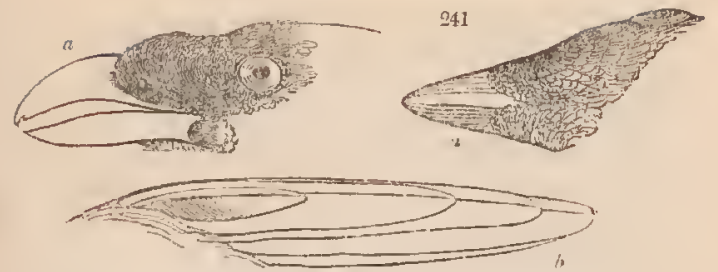

Ptruonoryncruve, Kuhl. (fig. 241.) Size large. Bill short, very thick, convex above $(a a)$ : both mandibles distinctly notched. Nostrils placed half-way between the gape and the tip, partly conccaled by the short thick-set feathers of the front, which lie on the basal half of the bill. Wings ratlier short, rounded; the first and sccond quills graduated; the third slorter than the fourth and fifth, which are longest $(b)$. Tail moderate; the feathers broad, their tips truncated. Feet ambulating, large, and very strong. Middle toe and tarsus of equal length; hinder toe very strong, but much shorter; lateral toes unequal, the outur longest, and united to the middle as far as the first joint. Australia.

P. holosericeus. Pl. Col. 395. 422.
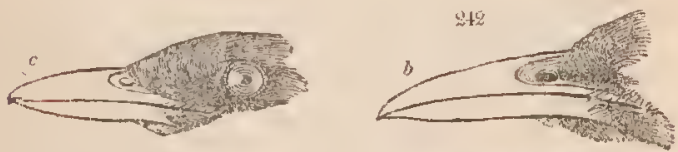

Lamprotornis, T'emminck. Gralkle. (fig. 242.) Bill thrushlike, compressed its whole length. Cul-

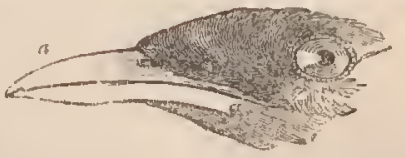
inen curved from the base to the tip. Upper unandible notched. Commissure slightly curved. Nostrils midway between the tip and the gape, naked, but with the frontal feathers rcaching to their base. Wings 
long, amplc; the first quill spurious; the third, fourth, and fifth of equal length, and longest. Tail short, even, rounded, or (as in the rasorial type (b)) considerably lengthened, and cuneated. Feet very large and strong. Middle toe and tarsus equal; hinder toe strong, but much shorter; lateral toes unequal.

L. ptilonorynchus. West. rufipennis. Ois. d'Af. pl, 83, Af. i. 140. (fig. $242 . a)$ 84. (b)

chrysonotis. Ib. i. pl. 6. albiventris. Part 5. No. 53. cyanotis. Ib. i. 146. (c) fulvipenuis. Part 5. No. 54. rufiventris. Ib. i. 151. melanngaster. Part. 5. No. 52. leucogaster. Ib. i, pl, 8. longicauda. IV. Af. i. pl.7.(b)

\section{Subram. SCAPHIDURINAE. Boat-Tails.}

Bill of a very lcngthened conic shape, entire, and compressed: the culmen slightly curved. Tail graduated, the sides reflected upwards, or boat-shapal. Feet strong.

Astrapia, Vieillot. General structure of Lamprotornis; but the tail excessively long and boat-shaped.* A. gularis. Vieil. Gal, pl. 107.

Scaphioura, Sw. Bill longer than the head, conic. Both mandibles equally thick. 'The base of the culmen broad, flattened, and advancing very far on tle front of the head. Commissure angulated at the basc, and sinuatcd on the sides. Nostrils basal, placed in a small triangular lollow on the sides: the membrane obsolete. Wings lengthened, pointed; the first quill longest. 'Tail morlerate, grarluated, boat-shaped. Feet strong. Middle toc and tarsus of equal length ; hincler toe much shorter; inncr toe hardly shorter than the outer. South America.

S. barita. Part 5. No. 62. crassirostra. Ib. No. 63. Quiscalus, Vieillot. Bill longer than the hear, com. pressed. Both mandibles equally thick. Culmen slightly curved, and compressed from the base, where it simply divides the frontal feathers, without being

* Not having a specimen of this excessively valuable bird to examine, I am unible to add its full characters: and nothing essential can be learned from II. Vieillot's cietinition. 
dilated. Commissure considerably sinuated. Nostrils basal, naked; the aperture round. Wings moderate, somewhat pointed; the two first quills slightly shorter than the third and fourth, which are the longest. Tail rather lengthened, much graduated, boat_shaped; tips of the lateral feathers truncated. Feet large, strong. Middle toe and tarsus equal; hinder toe shorter; inner toe scarcely shorter than the outer. America.

Q. versicolor. Part 5. No.55. tenuirostris. Part 5. No. 58. purpuratus. Ib. No. 56. macrourus. Ib. No. 59. lugubris. Ib. No. 57. corvinus. Ib. No. 60 . inflexirostris. Ib. No. 61 .

Scolecophagus, Sw. Bill shorter than the head, straight, slender; the margins inflexed, but not sinuated. Wings moderate, pointed ; the first quill rather sliorter than the secoul. Tail divaricated, flat, and slightly rounded. Legs lengthencd, slender, formed for walking. Middle toe and tarsus of cqual length; linder toe shorter; lateral toes of equal length. Claws slender, acute, slightly curved.

S. ferrugineus. Wilson, 21. f. 3. minor. Part 5. No. 65.
Mexicanus. Part 5. No. 66.

Subram. ICTERIN ZE. Hangnests.

Bill completely conic, entire, rather shorter than the head, either straight, or with both mandibles slightly bent. Feet formed for grasping: the claws thick, broad, and much curved.

Cassicus, Daudin. Cassicans. Bill rather longer than the head; the basc thick, very convex, and enlarged into a broad oval plate, which advances very far on the front, and divides the frontal feathers. Nostrils oval, nakcd, basal, pierced in the solid substance of the bill, and close to the margin of the upper mandible. Commissure straight, but angulated at the base. Wings rather long; the first and second quills graduated. Tail graduated. Feet short, very strong. 
Hind toe and elaw nearly as long as the tarsus. Tropical America.

C. cristatus. Br. 13irds, pl. 32. icteronotus. Br. Birds, pl.3. hemorrlous. Ib, pl. l. nigerrimus. Ib. pl. 4. affinis. Ib. pl. $2 . \quad$ coronatus. Ill. Or. 45.

Zantuornis, Cuv. Bill not longer than the head, generally shorter; perfectly straight; the culmen not dilated at the base, but simply dividing the frontal feathers. Wings moderate, pointed; the first three or four quills generally or nearly equal. Tail moderate, rounded. Feet moderate, but with the hinder toe manifestly longer than the tarsus; lateral toes unequal. America.

\section{Z. Baltimorii. Wils. pl. 1. f. 3 .}

Icterus, Cuv. Bill somewhat lengthened, as long as the head, or longer : hoth mandibles slightly eurved, and considerably attenuated. Nostrils basal, rather large, eovered above by a membrane; the aperture lateral and oval. Wings moderate; the first and second quills rather shorter than the third. Tail somewhat lengthened, graduated. Feet moderate. Inner toe shorter than the outer; hinder toe shorter than the tarsus.

I. castaneus. Wils. pl. 4. f.1-4. tibialis. Part 5. No. 67.

Chrysonus, Sw. (fig. 243.) Bill resembling Zanthor nis; but the margin of both mandibles inflexed. Wings moderate; the first quil rather shorter than the second. Tail rounded. Fect formed for walk. ing. Toes large, very

243

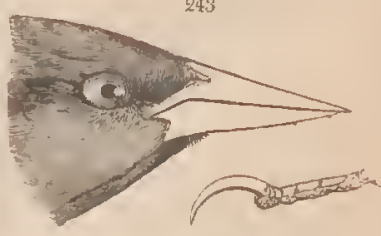
long, and slender: middle toe longer than the tarsus; lateral toes equal; hinder toe shorter than the tarsus. Claws long, very slender, and but slightly curved.

icterocephalus. Edw.p1.323. zanthopygius. Part 5. No. 190. 
SubaM. AGLAINA. Maizers.

Bill short, thiek, entire, eompletely conie, sometimes depressed, and rounded at the tip. Culmen rather broad, and flattenfel at the base. Legs long, slender, formed for walking.

Dourcionyx, Sw. Bill very short, finch-like, eonic, entire, shorter than the head; the commissure sinusated. Wings pointed; the first and second quills longest, and nearly equal. Tail slightly graduated, subseansorial; the tips aeuminated, and somewhat rigid. Legs long, slender. Middle toc longer than the tarsus; latcral toes unequal, the inner longest; hind toe of equal length with the tarsus. Claws long, very slencler, and slightly curved.

D, oryzivora. Wils. 12 . f. 1,2 .

Ageraius, Vieillot. Bill short, very conic, entire ; the tips compressed; thic culmen flattened towards the base; sides of the mandibles inflexed. Wings lengthened; the two first quills longest. Tail sliglitly rounded. Legs long, slender. Middle toe nearly as long as the tarsus; lateral toes equal; hinder toe not so long as the tarsus. Claws long, very slender, and but slightly eurverl. Amerien.

A. phenicaes. Wils. pl.30.f. 1. pustulatus. Part. 5. No.70. ruficollis. Part 5. No. 68. xanthocepialus. Bon. Orn. sulcirostris. Ib. No. 69 pl. 3. f. 1. 2.

LEistes, Vigors. Bill lengthened, conic, very straight; the culmen depressed from the hase to the tip, which is flattened. Wings moderate; the first quill rather shorter than the three next, which are the longest. Tail rounded. Juegs large, strong. Middle toe longer than the tarsus; hinder toe shorter; lateral toes unequal, the outcr one shortest. Anterior elaws slender, and but slightly curved; the outer one smaller than the inner; hinder elaw mueh stronger and more curved than the middle one.

I. erythroceplaalus. Zool. Miss. tenuirostris Part 5. No.7s. i. pl. 36 . niger. Ib. No. 74 . oriolides. Part 5. No. 71. unicolor. Ib. No. 71. brevirostris, Ib. No. 72 . 
Mocothrus, Sw. Cowpen. Bill very short, thick, finchlike, conic, entire ; the culmen not flattened, but slightly arched from the base, which is rather elevated. Wings lengthened, pointed; the first quill longest. Tail slightly rounded. Middlc toe as long as the tarsus; lateral toes of equal lcngth; hind toe shorter than the tarsus. All the claws rather small, and fully curved.

M. pecoris. Wilson, pl.18. brevirostris. Part5. No. 76. f. 1-3.

Sturnflua, Vieillot. (fig. 244.) Bill long, equal to the length of the head, conic, much depressed towards the tip, where it is broader than high : culmen dividing the fron tal feathers, where it is depressed and flattencl Wings moderate; first

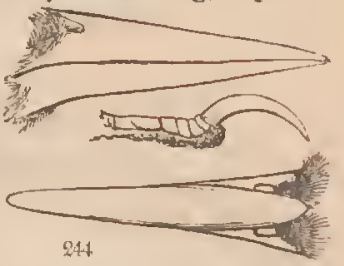
quill rather shorter than the second. Tail short, rounded; the feathers rather narrow. Feet large, but slender. Tarsus longer than the middle toe. Lateral toes unequal, the inner shortest; hind toe not much shorter than the middle. Anterior claws small, and of equal size; hinder claw (typically) twice as large as the others.

S. collaris. Veill. Wilson, militaris. PI. Enl. 113. pl. 19. f. 2. ( fig. 244.)

\section{FAmLY FRINGILLID A. Finches.}

Size generally small. Bill more or less short and conic, not so long as the head, and very thick at its base.

SubaM. COCCOTHRAUSTIN年. Hard-Bills. Bill pre-emincntly large, strong, and conic ; the curvature of both mandibles towards the point being more or less equal: the culmen rarely arched, or bent down at the tip. Upper mandible either entire, or with a very slight and almost obsolete notch. 
Cuccoturaustes. Size moderate. Bill very conic. Wings without a small spurious quill.

Pyrenestes, Sw. Bill enormous, perfectly conic ; the two mandibles equal, or the lower somewhat thicker: upper mandible with an obsolete tooth at its base; the tip entirc; the commissure straight. Wings and tail rounded; first quill very small, spurious. The Old World.

P. sanguinea. W. Af. i. pl. 9. frontalis. Part 5.No. 116. Coccoborus, Sw. ( $f i g .245$.$) Bill very large, almost$
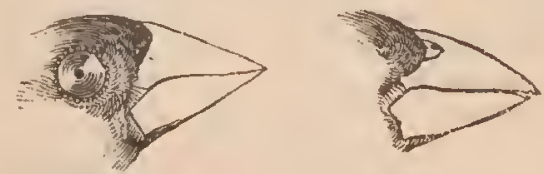

perfectly conic; the two mandibles equal; the upper sinuated in the middle, the tip rather exceeding that of the lower, and with a very slight notch: commissure sinuated. Wings and tail more or less rounded ; the first quill nearly as long as the second. America only.

C. cærulea. Wilson, pl. 24. f. 6.

Coccothraustes, Briss. Bill very large, rather imperfectly conic; the upjer mandible much thicker than the under; the tip entire; the commissure simply arched, without undulations. Wings long; the first, second, and third quills ncarly equal. 'Tail short, more or less forked. Northcrn America, Europe, and temperate Asia.

C. Europiseus. Selby, pl.55. f.1. vespertina. N.Z.ii. pl.68.

Spermophaga, Sw. Bill moderate, conic, but rather lengthened; upper inandible thicker than the under; the tip entire; the commissure sinuated. Wings and tail much rounded; the first quill fully developed, but only half as long as the fiftl. Africa.

S. cyanorynchus. West. Af.i. 164. Vieil. Ois, Chant. pl.67, 68. 
Dertroides, Sw. Bill lengthened, conic, compressed: the basal part of the culmen swollen, elevated, and advancing on the front of the head; the rest slightly curved. Nostrils entirely naked, basal, pierced in the naked substance of the bill. Commissure sinuated. Under mandible thinner than the upper. WWings and tail round; first quill spurious, but lalf as long as the second. Feet strong. Lateral toes equal.

D. albirostris. West. Af. i. 169. Pl. Col. 446.

Puocnus. Weavers. Size small. Bill conic, but with the the culmen slightly bent, and the tip en tire. Under mandible less thick than the upper. Claws large, very long. (fig.246.a) Wings pointed; but the first quill remarkably short and spurious. The Old World only. Vifua, Cuvier. ( $f g .246$.$) Bill short. Wings length-$
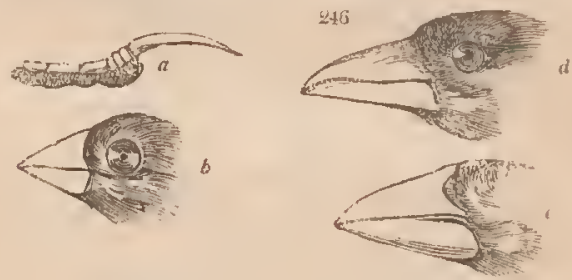

enerd; the second, third, and two following quills longest, and of equal length. Tail boat-shaped: males with the two middle feathers excessively elongated, generally broad and convex.

V. rufitorques. W. Af. i. 174. (c) chrysnotus. W. Af. i. 174.(d) erythrorynchus. Ib. (b) paradisea. Ib. pl. 11.

Eruplectes, Swains. (fig. 247.) Bill shorter than the head. Nostrils round, partly concealed by the frontal feathers. Wings short; the second quill shorter than the third; tertials as long as the primaries. Tail short, even, or very

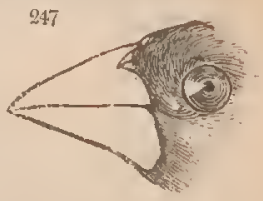
slightly rounded. Feet large, gracile. 'Toes very 
long and slender; the lateral of equal length. Claws slender, very slightly curved. (c)

E. ignicolor. Ois. Ch. pl. 59. melanogaster. Brown, Ill. flamuniceps. W. $\Delta$ f. i. pl. 13. pl. 24. f. 2. oryx. O. Cliant. F]. 66. albirostris. Part 5. No. 88. sanguinirostris. Ib.pl.22. lepidus. Ib. No. 89.

Capensis. P. E. 101. f. 1. flaviceps. Ib. No. 90.
(fig. 247.)
Philippensis, Ib. No. 91.
rubra. Part 5. No. 87. aurinotis. Ib. No. 92.

Ploceus, Cuv. ( fiy. 247.) Bill considerably lengthened, as long as the hearl. Nostrils almost naked. Wings moderate; the second, third, fourth, and fifth quills nearly equal; ter-

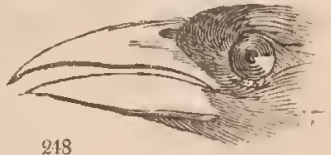
tials shorter than the primaries. Tail short, even. Feet large, thick. Tocs robust; the lateral equal. Claws strong, thick, fully curved. (fig. 248.)

P. textor. Zool. 111. ii. pl. 37. personatus. Part 5. No.81. brachypterus. West. Af. i. melanotis. Ib. No. 82 . pl. 10. cristatus. Part 5. No. 77. cucullatus. Ib. No. 84 . rubricollis. Ib. No. 78. ruficeps. Ib. No. 85. niger. Ib. No. $79 . \quad$ erythrocephalus. Ib. No.86. aurantius. Ib. No. 80. auricapillus. Ib. No. 195.

Symplectcs, Sw. (fig. 249.) General structure of Ploceres; but the bill is nore compressed, the commissure curved, but neither sinuated nor toothed. Wings short, rouncted; the first quill

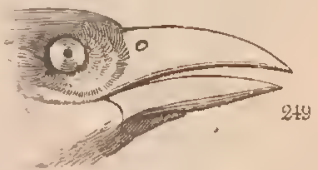
half as long as the second, which, with the third, is graduated; the three next are nearly equal, and are the longest. Tail moderate, cven. Feet strong. The middte toe abbreviated; imer lateral toe shorter than the outer; hinder toe long, equal to the middle toe.

S. chrysomus. West. Af. i. 170.

Aradiva, Swains. Bengaly. Sizc very small. Bill very short, conic. Wings pointed. Spurious quill minutc. 
Feet moderate, or small. Tropics of the Old World only : represented by Tiaris in America.

Estrelda, Sw. Bill small, moderate. Tail lengthened, graduated, or rounded. Fect moderate. Tarsus longer than the hallux.

E. melanogaster. W. Af. i. 194. phocnicotis. Ib. pl. 14. cærulescens. Ib. i. 195.

Amadina, Sw. Size larger. Bill short, very thick and broad at the base. Tail short, rounded, or even. Tarsus longer than the hallux.

- A. fasciata. West. Af. i. pl. $15 . \quad$ nitens. Ib. i. 199. spermestes, Sw. Bill short, thick. Feet very large. Tous and claws long and slender. Tail short, even. Chiefly India.

S. cucullata. West. Af. i. 201.

Erythura, Sw. Bill thick, lengthened, resembling that of Extplectes. Tail very long, acuminated.

E. viridis. Pl. Col, 96.

Pytelia, Sw. Bill slender, conic, much lengthened. Tail short, even. Feet very small.

P. phonicoptera. West. Af. i. pl. 16.

T1A11s, Swains. Crestlet. Bill perfectly conic, entire: commissure sinuated, and conspicuously angulated. Nostrils almost naked, round. Wings moderate ; first quill rather shorter than the second, third, and fourth, which are equal, and longest. Tail even, or slightly rounded. Feet moderate. Middle toc and tarsus of equal length; lateral toes equal ; hinder toe much shorter than the tarsus. Claws small, fully curved.y Head crested. South America only.

T. or aatus. Pl. Col. 208.

Carnueurs, Briss. Goldfinch. Bill lengthened, conic, compressed; the tip much attenuated and acute; the gonys straight; commissurc slightly sinuated. Wings lengthened, pointed; the first, sccond, and third quills nearly equal, and longest. Tail moderate, slightly forked. Feet short. Middle toe longer than the 
tarsus, which is equal with the hind toe; lateral toes short, equal. Anterior claws small ; hinder one long; all slender. Europc, Afriea, Ameriea.

C. Europæus. Selby,pl.55.t.819. Americanus. Wils.pl.1.f.2.

LinaRIa, Briss. Bill very short, conic, thick at the base ; the sides of the upper inandible rather gibbous; the margins inflexed. Commissure not sinuated. , Wings long, pointed. Tail forked. Fect short. Tarsus shorter than the middle toe. Lateral toes equal; hinder toe nearly as long as the tarsus.

Linaria. Linnets. Claws very slender, slightly curved, and much lengthened. The hinder toe of equal length with the claw.

L. eanabina. Selby, i. pl. 55. f. 3.4.

Leucosticte, Sw. Bill tumid. Commissure regularly curved. Wings much lengthened. Tarsus lengthened, slender. Hind claw very long.

L. tephrocotis. N. Z. pl. 50.

Chloris. Greenfinch. Bill larger and stronger: the commissure straight. Claws smaller, and more curved.

C. flavigaster. Selliy, i. pl. 54. f. 3.

SUrras. TANAGRINA. Tanagers.

Bill unequally conic ; the upper mandible more or less arehed, and very distinctly notched. Feet formed for pereling. Claws broad, and fully curved. T:ARDivola, Sw. Bill lengthened, conie, somewhat slender; the sides not gibbous; the commissure slightly or not at all sinuated. Wings very short; the first quill shorter than the four ncxt, which are equal and longest. Tail lengthened, euneated or gra-

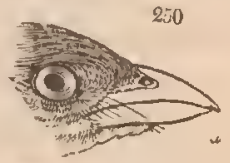
duatcd. Feet large. Tarsus and toes long. Outer toe rather shorter than the inner. Claws slender, slightly curved. ( $f i g .250$.)

T. sphenura. Pl. Col. pl. 114, f. 2. ( $\alpha)$ 
Tanagra, Linn. Bill very short, thick, strong; the commissure slightly sinuated; the sides swollen.
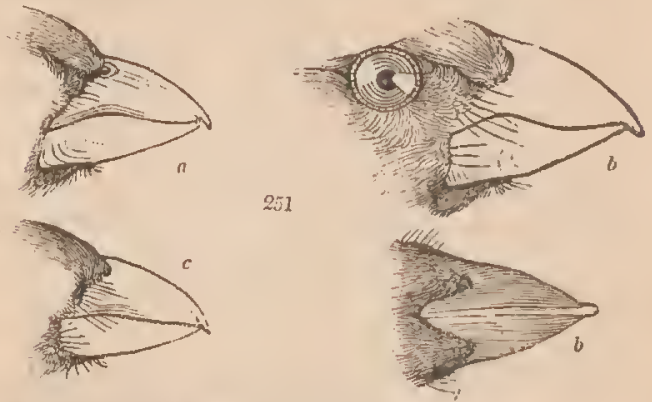

Pitylus, Cuvier. (fig. 251.) Bill very large, short, subconic. Mandibles equally thick: the upper mandible swelled on the sides; the tip reflected, and distinctly notched; the margin strongly sinuated in the middle. Wings sliort, rounded; the three first quills slightly graduated; the fourth and fifth equal, and rather longer than the third. 'I'ail mode-

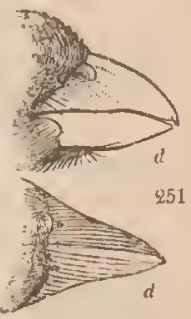
rate, rounded. Feet moderate strong. Lateral toes equal; hiuder rather short. Tarsus and middle toes equal. Claws sinall, fully curverl.

P. picatus. V. G. pl. 140. (d) superciliosus. Sw.sp.nov. $(a)$ atricullis. Spix,ii.pl.56.f.2. erythrorynchus, 11l. of Orn. capistratus. Ib. ii. pl. 54. pl. 3. (b) f. 1. (c)

Tanagra, Linn. (fig. 252, 253.) Size smaller. Bill not
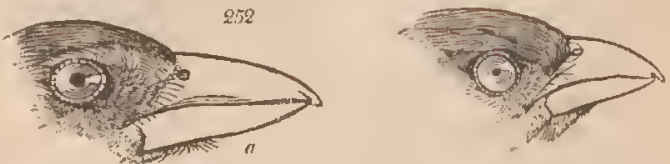

swollen on the sides; the commissure very slightly or not at all sinuated in the middle. IVings some- 
what pointed; the first and second quills searcely shorter than the third, which is the longest. Tail moderate, even. Middle toe and tarsus of equal length; lateral toes unequal, the imner sliortest.*

olivacea. Vieil. G.p.77. ( fig. 252, a) serioptera. Parı 5. No. 99.

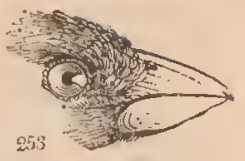

Ramphopis, Vieillot. (fig. 254.) Bill rather short: the under mantible more or less thicker at its base than the upper, and gencrally eonsiderably dilated and flattened; the margins inflexed. Commissure simply eurved. Nostrils basal, partially naked; the aperture

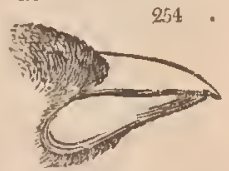
round. Wings short; the two first quills slightly graduated ; the third, fourth, and fifth equal, and longest. Tail much rounded. Feet slender, moderate. Tarsus and middle toe of equal length; lateral toes the same. Claws slender, curved.

atrococcincus. B. 13ds. pl, 20. nigrogularis. Ib. pl.17. coccineus. Ib. pl. 18, 19 .

Pucnisoma, Sw. Bill lengthened, conic. The upper mandible strongly sinuated or obsoletely toothed in the middle of the commissure.

Lamprotes, Sw. (fig. 255.) Bill lengthened, subconic, compressed from the base. Commissure simply curved. Gonys straight. Culmen arclied. Nostrils eutirely naked; the aperture round, simple. Wings rather lengthened, somewhat pointed; the

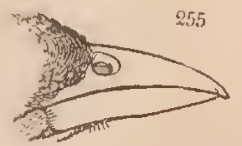
first quill hardly shortened; the second longest. Feet very short. Tail even. Middle toe longer than the

* I find it impossible to determine, at this moment, which are the precise species of the other exarnples here figured of this intricate genus. They will, however, illustrate the forms between Pitylus and Ramphopis, which is the most material object I have had in view. 
tarsus; lateral toes unequal; hinder toe as long as the tarsus.

L. rubrigularis. Spix, ii. pl. 58. f. I.

Phanisoma, Sw. ( $f i g$. 256.) Bill lengthened, subconic, cylindrical, or sometimes with the base broader than high; the tip reflected and notched: the margin of the upper mandible with an angulated or toothlike lobe in the middle, and folding over the edge of the lower mandible. Nostrils small, concealed by the short frontal feathers. Wings lengthened, and pointed; the first quill hardly shorter than the second, which is the longcst. Tail moderate, even, or
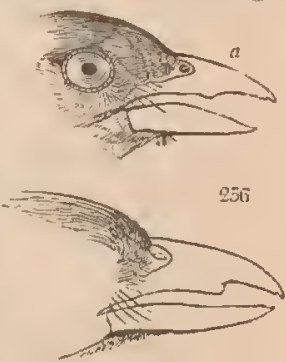
slightly rounded. Feet very short. Middle toe longer than the tarsus; inner toe ratler shorter than the outer; hind toe not quite so long as the tarsus. (Pyranga, Vieillot.)

P. rubra. Wilson, pl.11. f. 3. (a) astiva. Ib. pl. 6. f. $3,4$. Tachyphonus, Vieil. (fig.257.) Bill lengthened, subconic; the sides compressed; the tip reflected and notched. Margins of both mandibles reficcted inwards:
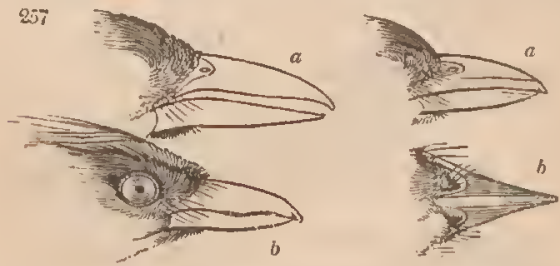

the commissurc sinuated, and often toothed in the middle of the upper mandible. Wings moderate, rounded; the third and fourth quills longest. Tail rather lengthened, rounded. Feet moderate, slender. 
The middle toe and tarsus of equal length; lateral toes cqual.*

nigerrimus. Pl.Enl.179.f.2.(a)

cristatus. Ib. 7. f. 2. (b)

Leucopygia, Sw. (fig. 258.) Bill entire, neither mandible being notched; somewhat slender, much compressed. Commissure sliglitly or not at all sinuated. Rictus smooth. Nostrils naked. Wings modcrate. Tail rounded. Feet very strong. Lateral toes equal. Claws fully curved.

L. ruficollis, Part 5. No. 97.

Nemosid, Vieillot. (fig. 259.) Bill slender, rescmbling that of a Sylvia, but stronger, more lengthened, and with the commissure very slightly sinuated: base of thc under inandible as thick, and sometimes thicker, thian that of the upper. Wings rather lengthened; the first quill auricapillus. Sw. Monog. (c) phonicius. Part 5. No. 93.

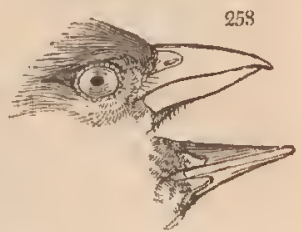
hardly shorter than the three next, which are the longest. Tail even. Feet small. Lateral toes equal. N. flavicollis. Vieil. G. pl.75. pileata. Pl. Enl. 720. f. 2. ruficapilla. Ib. (plate without a number.)

AgLAïA, Sw. ( $f(j) .260$.$) Size$ small. Bill short, slender, notched; the base with thick-set feathers, which more or less cover the nostrils. Wings rather lengthened ; the first, and sometimes the second, quill slightly abbreviated. Tail short, even. Feet rather

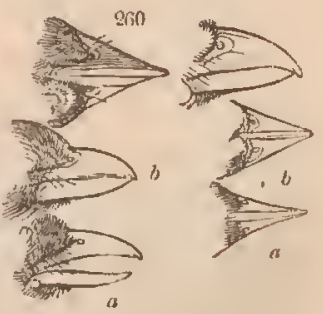

* In $T$. nigerrimus the feet are strong, and the inner toe much shorter. This species scems to me intimately connected with the subgenus Lamprotes. 
small. The inner toe shorter than the outer. Claws broad, and fully curved. paradisea. Pl.Enl.127.f.l. cucullata. Braz. Bds. pl. 7. gyrola. Zool. Ill.ii.pl.28. cyanoptera. Ib. pl. 8. (a) cyan oceplath. Braz. B. pl.5. flava. Zool. Ill. pl. 31. citrinella, Ib. pl. 6. ehrysoptera. Pl. Lnl.133.f.2.

Euphonia, Vieil. Bill very short, broad, and triangular : tip of the upper mandible with one or two notches. Wings lengthened; the first and second quills longest. Tail short, divaricated. (fig. 260.6.)

I. caculcocephala. Nob. P. kinl. 809. f. I.

Tanagrelln, Sw. Bill very slender, compressed, and much lengthened. The lateral toes equal.

T. multicolor. Nob. Part 5. No. 98. Pl. Enl. 669. f. 3. ? Pirırıo, Vieillot. (fig. 261.) Bill conic, finch-like, hard: the upper mandible but slightly notched; the tip not bent downwards; and the culmen very slightly arched, having a slight gibbosity at its base, close to the front: commissure much sinuated, and often angulated: the margins inflexed. Wings short; the two first quills graduated. Tail large, broad, lengthened, rounded, generally tipt witl white. Feet very large and strong. The inner toe shorter than the outer. Thle claws slender, and but slightly curved. erythropthalmus. Vieil.G. fusca. Part 5. No.197. pl. 80.

maculata. Ill. 0.pl.31,32. aretice. N.Zool. ii. pl. 51 . matronyx. Part 5. No.196.

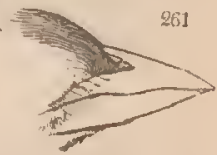

Arremon, Vieil. 13 ill short, conic, finch-like; the sides compressed; the tip of the under mandible very slightly notcher, but not inflected over the lower; the commissure straight, the edges inflected. Nostrils small, basal, concealed by the frontal plumes. Wings very short, rounded; the threc first quills graduated. Tail moderatc, considerably rounded; the feathers narrow, and obsolctely pointed. Fcet large, slender. 
Tarsus longer than the middle toe. Lateral toes equal. Claws slender, and but slightly curved.

A. torquatus. Vieil. G. pl. 78. flavirostris. Part 5. No.198.

Subfam. FRINGILLINA. The Cround Finches.

Bill short, in general very conic, obsoletely notched or entire. The culmen not curved. Feet formed for walking.

Prraita, Antiq. Sparrow. Bill unequally conic, short, thick: sides of the upper mandible swollen; the tip notched: the base of the culnon rather broad and convex: the commissurc straight. Wings moderate; the three first feathers longest, and of equal length. Tail moderate, even, divaricated, or very slightly forked. Tarsus shorter than the middle toe. Lateral toes nearly equal. Claws fully curvel. The old World.

P. domestica. Sel. pl. 54. f. 4, 5. simplex. West. Af. i. 208. arcuata. 1. Enl. 230. f. 1. indica. Ill. Orn. iii. pl.118. Aimophila, Sw. Bill morc lengthened, unequally conic, compressed: the base of the culmen elevated and dividing the frontal featlicrs. Upper mandible slightly notched at the tip, and thicker at the base than the under onc: commissure sinuated: culmen slightly arched froin the base. Wings slort, rounded; the two first quills graduater. T'ail moderatc, rounded; the fcathers rather narrow. Feet strong. The lateral toes nearly equal. Claws slender, slightly curved. America only. G.rufesecns. Part 5. No. 102. superciliosa. Ib. No.101.

Leucophrys, Sw. ( $f(y .262$. Bill unequally conic ; the sides not swollen; the tip entire. Nostrils naked, round. Wings lengthened; the first quill spurious, the three next almost equal. 'Tail rather sliort, even; the covers very long. Feet

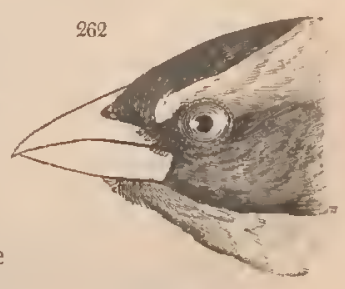


strong, robust. Lateral toes unequal, the inner shortest. Claws strong, and fully curved. Africa.

L. pilentus. Part 5. No. 199.

Frinfirua, Linn. Bill lengthened, conic; the culmen not curved; the tip slightly notched, but not reflected. Commissure straight. Claws small, slender, but slightly curved.

Passerella, Sw. Bill short and perfectly conic, thick at the hase, and rather abruptly pointed at the tip, which is entire. Culmen perfectly straight. Both mandibles of equal thickness. Wings moderate; the first quill shortcr than the second, third, and fourth, which are the longest. Tail morlerate, broad, and nearly evcn. Feet large, strong. Middle toe longer than the tarsus; inncr toe much shorter than the outer. Claws long, slender, and but slightly curved; hinder claw as long as the toe. Ainerica.

P. Iliaca, Wilson, iii. 22. f. 4.

Fringilla. Bill forming a perfect, slightly lengthened cone, with both mandibles of equal thickness; the uppcr one sliglitly notched, but not inflexed at the tip: the commissure straight. IVings lengthened, pointed; the first quill always longer than the fifth. Tail moderate, forked ; the outermost feathers the longest. Legs slender. Tarsi moderate. Latcral toes equal ; middle toe very long. Europe and America.

F. coelebs. Scl. pl. 54. f. 6, 7. hyemalis, Wils. ii. 16 . f. 6 . montifringilla. Ib. f. 8,9 . grnminea. Ib. $31, \mathrm{f} .5$.

Zonotrichia, Sw. Bill as in Fringilla: the commissure straight. Wings not lengthened; the first quill shorter than the four next, which are of nearly equal length. 'Tail rather lengthened, slightly divaricated; the outermost feathers shortened. Lateral toes slightly unequal. Tarsus and middle toe of equal length. America only.

leucophrys, Wils. iv, 31, f. 4. albicollis. Wils. pl. 22 . f. 2. Pennsylvanica. Ib. iii.5. f. $2 . \quad$ subtorquata.* Sp. ii. 53. f. 3.

* The specific name of graminer, given by Spix to this bird, had been previously used by Wilson for another. 
Ammodramus, Sw. Bill with the commissure sinuated, and the tip slightly inflexed. Wings very short, reaching only to the base of the tail ; the five first quills of equal length, and scarcely longer than the sccondaries. Tail moderate, very slencler, and graduated; the feathers narrow, lanceolate, and somewhat rigid. Feet slender. Lateral toes equal; hind toe and claw longer than the tarsus. Claws very slender, and but slightly curved.

A. caudacuta. Wils. pl. 34 palustris. Wils. pl. 22. f. 1. maritima. Ib. 34. f. 2.

Chondestes, Sw. Larkfinch. (fig. 263.) Bill resembling Passerella, but the tip slightly inflexed and notched: the commissure consiclerably sinuated, and lobed in the middle. Wings lengthened, rather pointerl; the three first quills ncarly equal. Tail

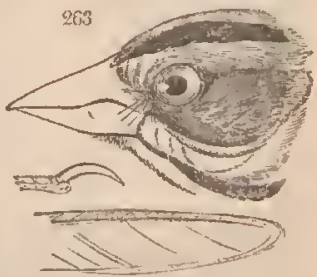
much rounded; the fcathers broad, and the three outer graduated. Feet modcratc. Hinder toe and claw much longer than the lateral toes, which are equal.

C. strigata. Sw. Syn. Mex.; also Bon. Am. On. i. pl. 5. f. :3. Esmeriza. Buntings: Bill conic. Culmen nearly straight. Under mandible thicker than the upper, which is furnished with an internal knob; the tip with an obsolete notch: the margins of both mandibles inflexed. Hinder and inner toe of equal length. Claws slender, curved. Tarsus and middle toe equal. Emberisa, Linn. Wings moderate; the first quill shorter than the four next, which are the longest. 'Tail forked; the feathers narrow, and somewhat lanccolate. Lateral toes unequal, the inner shortut; middle toe lengthened. Europe and America.

E. schœniculus. Selby, pl. $52 . \quad$ Causadensis. Wil. ii. 163. f. 5,6 .

socialis. Wil. ii. 18. f. 5

Fringillaria, Swains. Bill with upper mandible entire. voL. II. 
Wings short; the primary quills not much longer than the tertials. Tail moderate, eithor quite even, or very slightly rounded. Lateral toes small, equal. All the claws small and short. Africa, also India? F. capensis. Pl. Enl. 664.2. rufa. Part 5. No. 10.3. striolata. Rüp]). Atl. 10. a, vittata. Ib. No. 104. cxsia. Ib. 10. b. anthoïdes. Ib. No. 105.

LePronyx, Sw. Bill intermediate between Emberiza and Ammodramus. Culmen slightly arched from the front. Under mandible rathcr thicker than the upper, which is notched: commissure sinuated and angulated at the base; the margins inflexed. Wings short; the three first quills nearly equal. Tail moderate, graduatcd. Feet as in Ammodramus; but the hind claw as long as its toc.

$$
\text { L. melanotis. Part 5. No. } 100 .
$$

Melophus, Sw. General structure of Fringillaria; but the uppor mandible is notched near its tip. Hinder claw lengthened, but rather shorter than its toe. Lateral toes equal. Tail even. Head crested. Tertials not lengthencd.

M. erythropterus. IIl. of Orn. pl. 132.

Pumctrominanes, Meyer. Bill very conic; the tip perfcctly entirc: the under inandible thickest, with the general structure of Emberiza. Lateral toes equal. Claws nearly straight. Hind toc and claw longer than the lateral toes; the claw much lengthened. Wings long, pointed.

Miliaria, Sw. Bill of Emberiza. Wings moderate, pointed ; the threc first quilis the longest, and nearly of equal length. Tarsus short, strong. Middle toe much lengthened, and longer than the tarsus; lateral toes short, perfectly equal. Hinder claw rather shorter than the toe, and slightly curved. Europe.

M. Europaa. Sel. pl. 52. f. 1. citrinella.* Ib. f. 2, 3.

Plectrophanes, Meyer. Bill of Emberiza. Wings

* The yellowhammer is, no doubt, an aberrant species, indicating that the group hetween this and our Eimberiza, has the upper mandible faintly notched. This group seems represented iy Melophus. 
long; first quill longer than the second, the rest graduated. 'Tarsus short. Middle toe and elaw moderate, not longer than the tarsus; lateral toes short, perfectly equal. Hinder elaw as long as its roe; anterior elaws sinall, and all of them nearly straight. Ainerica and Europe.

P nivalis. Selby, pl. 52. f. 7. I.apponica. N. Z. ii. pl. 48. Wilson, iii. 21. f. 2. picta. Ib, ii. pl. 4!

Agnophilus, Sw. Bill resembling Chondestes; but the upper mandible is entire, and the base of the culmen far advaneed between the frontil feathers. Wings somewhat lengthened; the first quill

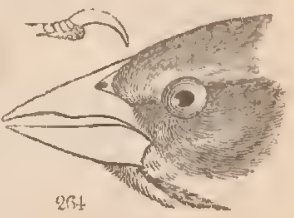
spurious, and not half so long as the seeond; fifth and second equal, third and fourth longest. Tail moderate, slighttly rounded. Feet large and strong. Mildle toe ratler longer than the tarsus; lateral toes equal, but shorter than the hinder. All the elaws strong, and fully curved. (.fig. 264 . )

A. superciliosus. Rüpp. Atlas, pl. 15. West Af. i. 209.

\section{SugFam. ALAUDIN EE. Larks.}

Bill more lengthened than in any of the Fringillide; the tip entire, or obsoletely notched. Tertial quills con. siderably lengthened, pointed, and gencrally as long as the quills. Claws very slight tly curved; the elaw of the outer toe always shorter than that of the inner toe; the hinder elaw eonsiderably lengthened, and either nearly straight, or very slightly curved.

Alauna, Linn. Bill eylindrical. Nostrils eoncealed. Wings very long; no spurious quill ; the first, second, and third quills longest, and nearly equal ; the rest considerably graduated; tips of the lesser quills emarginate. Tail forked. Ilead crested. Europe and America. The fissirostral type.

A. arvensis. Selby, 50, f. 1. cornuta. Wils. pl. 5. f. 4. 
Calenduxa, Linn. Bill thick, much compressed; the

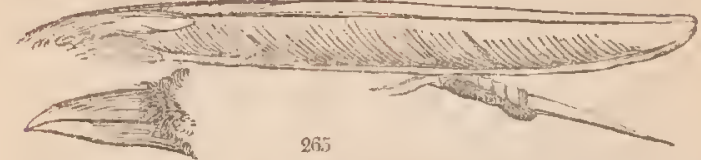

culmen curved and convex; the commissure arched ; the tip of the upper mandible wide above, and inflexed. Wings long, or moderate; the first quill very small and spurious; the sccond nearly equal to the third and fourth; lesser quills short, emarginate. 'Tail slightly forked. Lateral toes equal. Africa. The dentirostral type. (fig. 265.)

C. magnirostris, Ois. d'Af. pl. 193.

Myrafra, Horsf. Bill as in Calendula. Wings short, rounded; greater quills hardly longer than the secondaries and tertials; the first quill spurious, half the length of the second, which is shorter than the third; the third, fourth, fifth, and sixth equal, and longest. 'Tail short, even. Legs long.

M. Javanica. Lin. Tr. xiii. 159.

Braconyx, Sw. (fig. 266.) Bill as in Calendula. Hinder claw very short. Wings and tarsi much lengthened. $\Lambda$ frica.
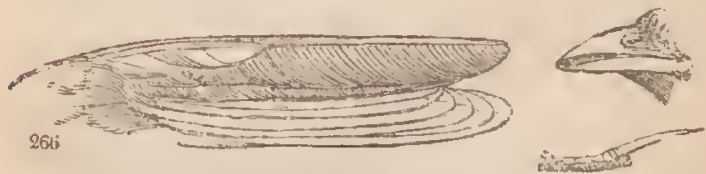

Agromizos., Sw. (Anihus pars Auct.) Bill slender, considerably compressed: both mandibles of equal length ; the tip of the upper one not reflected over the lower, and with a small notch, almost obsolete. Wings long; the four first quills nearly equal; the rest rapidly diminishing, and emarginate at their tips; tertials lengthened, pointed, as long as the quills. Tail moderate, even. Legs pale, long, 
slender. Tarsus longer than the middle toe. Lateral toes equal, but the outer claw shorter than the inner. Colour brown: lark-like. Distribution universal. The insessorial or pre-eminent type.

rufescens. P. E. 661.f. 1. bistrigata and Australis. Mart 5. >o. 107,108 .

Macronyx, Sw. (fig. 267.) Bill slender, compressed, thrush-like, entire. Nostrils large, naked, the aperture lateral. IVings short; the primaries not longer than the tertials,

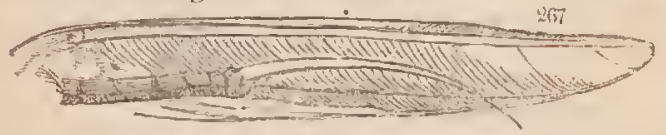

the four first of equal length; secondaries long, emarginate. Tail moderate, even. Feet enormous. Tarsus and hinder toe very long, and of equal length. Lateral toes unequal, the inner shortest. Africa. 'The rasorial type.

M. Alavicollis. O. d'A.pl.195. flavigaster. Sw. W. A. i. 215. Certhilauna, Sw. Bill slender, lengthened, more or less curved. Nostrils round, naked. Wings very long; the first quill spurious; the three next nearly

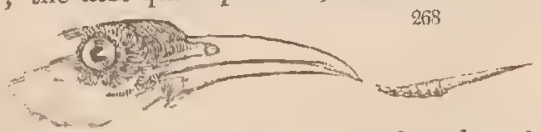

equal. Tail moderate, even. Feet lengthened. The lateral toes equal. Length of the hinder claw variable, although typically short and straight. Africa. The tenuirostral type. ( fig. 268.)

longirostra. Ois. d'Af. 192.

bifasciata. Rupp. Atlas, pl. 5.

Subam. PYRRHULIN K. Bulfinches.

Bill very short, thick, entire: the upper mandible arched both on the culmen and commissure. Wings with the four first quills of nearly equal length. 
Pyrreurauda, Smith. Bill short; the sides much compressed; the tip entire; the culmen arched: commissure straight. Nostrils concealed by the frontal feathers. IVings moderate; the first quill very small, and spurious; the three next equal, and longest. Tail moderate, slightly forked. Feet blzek. Tarsi moderate. Toes very small. Latcral toes equal. Hinder elaws lengthened, slightly curved.

leucotis. Pl. Col. 269. f. 2. melanosoma. Part 5. No. 108. cruciger. Ib. 269. f. 1.

Pvrnhula. Bill remarkably" short, swelled on every side: the upper mandible smaller than the under, and considerably wider above than it is high: culmen arched from its base: commissure curved. Wings modcrate; the four first quills of nearly equal length, and longest. Tail moderate, even, sometimes divaricatcd. Lateral toes unequal, the inner shortest; middle toe and tarsus cqual.

\section{P. vulgaris. Selby, pl. 54. f. 1, 2 .}

Crithagra, Sw. Bill short, resembling that of Pyrrhula. Wings moderate; the tlree first quills nearly cqual. Tail moderate, slightly forked. Tarsus shorter than the middle toc. Latcral toes equal. Claws lengthened, sleuder, acute, and but slightly curved; the hinder as long as its toe. Africa, India.

C. sulplsurata. I. O.109. f. 1 . cinerea. Part 5. No. 115. strigilata. Ib. No. 111. canicollis. Ib. No. 110. flava. Ib. No. 114. canaria. Part 5. No. 113. chrysopyga. W. Af. pl. 17. ruficandic. Part 5. No. 109. bistrigata. Ib. No. 112.

Spermophila, Sw. General structure of Pyrrhula. IBill less swclled. Tail rounded. Wings sliorter and nore rounded. Lateral tocs equal; middle toe longer than the tarsus. America only.

S. rubiginosa. Spix, ii. pl.59. f.1. albogularis. Sp. ii. 60. f. 1 . cinereola. Pl. Col. pl. 11.

Psittinostra, Temm. Bill sliort, much hooked, slightly swelled at its base: upper mandible with its tip curved over the lower, which has the tip rounded 
and obtuse. Nostrils basal, lateral, partly eloser by a membrane eovered with the frontal feathers. 'Tarsus longer than the middle toe. Lateral toes equal; all the toes divided to their base. Wings with the first quill wanting*; the seeond shightly shorter than the third. ('Tem. Manuel, 71.)

L. psittacia. Lath. Syn. 3. pl, 42.

Corythus, Cuv. Upper mandible projeeting and eurving over the tip of the lower. Tarsus much shorter than the middle toe, but longer than the hind toe. Lateral toes unequal, the inner shortest. Claws slender, attenuated, aeute, and not much eurved. Tail broad, and slightly forked.

\section{C. enucleator. N. Zool. pl. 53.}

HAmornous, Sw. Bill rather more lengthened than in Pyrrhula: the commissure sinuated. Wings lengthened, pointed. Tail forked. Feet short, robust. Middle toe mueh longer than the tarsus; inner toe rather shorter than the outer. Claws short, and fully eurved; the hinder shorter than its toe. America. II. purpureus. Wils. i. 7. f. 4 . frontalis. Bon. Am. Or. i.

Loxıs, Linn. Bill somewhat lengthened, muelı eompressed. Under mandible erossed at its tip over the extremity of the upper; the tips of both entire. Nostrils defended by ineumbent setaceous feathers. Wings long, pointed; the first quill longest. Tail very short, forked. Tarsus very short. Toes and claws large, robust; lateral toes short, unequal, the outer longest; hinder toe longer than the tarsus. All the elaws fully eurved.

L. pinetorum. (Meycr). Selby, curvirostra. Fdw. 305. pl. 53**. f. 1.

\section{Fanily MUSOPHAGIDA. Plantain-enters.}

Bill short: upper mandible high; the eulmen arehed; the margins either serrated or entire: the under man-

* 1re remige nulle. - Tem. This requires explanation, but we have not a specimen of this exceedingly rare bird. 
dible very thin. Feet short, formed for clinging. The toes various.

\section{SURFAM. PHITOTOMINE. Plant-cutters.}

Bill serrated, but not swollen. Feet with two or three toes forward, and one backward.

Prхтотоза, Molina. Bill short, compressed, the base widened; high at the base, and gradually curved: the lower mandible much weaker, straight: the commissure slightly archetl, with the margins crested. Tongue short, pointed. Nostrils basal, small, rounded. Wings moderate; the two first quills graduated. Tail moderate, even. Feet strong. Lateral toes unequal, the inner shortest. Claws slender, slightly curved.

P. rufescens. III. of Orn. i. pl. 5 .

Hxreus, Stevens.* Bill more lengthened, nearly as long as the head; the margins serrated. Tail forked. Toes only three, two before and one behind.

H. Abyssinicus. Lath. Syn. Sup. ii. pl. 133.

\section{Sueram. COLIN E. Colies.}

\section{All the four toes placed forward.}

Conus, Linn. Bill short: the upper mandible widened at the base, but very convex above : culmen elevaterl, and arched downwards : commissure entire : the margin of the upper mandible folding over the edges, and almost hiding the lower, which is very thin and straight. Nostrils large, basal, naked ; the aperture linear, oblique, and a little removed from the base of the bill. Wings rather short, pointed. Tail very long, cuneated ; the feathers very narrow, and somewhat rigid. Feet strong, four-toed. The exterior toe and the hallux (placed on the inner side) inserted in an oblique direction. Claws slender, rather acute, not much curved.

* Imperfect as is the above account, taken from the obscure description and rude figure of Dr. Latham, I feel filly persuaded that this is a perfectly distinct type from the true phytutome of the New World. The difference of food alone fanctions me in this opinion, if, as it is stated, the first lives upon the roots of plants, and the latter upon kernels of fruits. 
C. Senegalensis. O.d'A.pl.258. striatus. Ois. d'Af. pl. 256. leuconutus. 1b. pl. 257.

SURA MU. MUSOPAGINAE. Plantaineaters.

Three toes forward and one backward; the outer toe placed obliquely.

Conythaix, Illiger. Bill short, rather small, high, and greatly compressed. The frontal feathers reposing over and conccaling the nostrils. Culmen high, curved to the tip. Lower mandible narrow: both mandibles distinctly notched at the tip, and fincly serrated. Wings short, rounderl ; the three first quills graduated.' 'Tail long, broad, rounded. Feet short, strong. Middlc toe longer than the tarsus; lateral toes equal; hinder shortest; external toc capable of being turned a quarter of the way backward. Claws short, thick, and much compressed.

C. Persa. Pl. Enl. 601. erythrolophus. Pl. Col. 23. Buffoni. Edwards, pl. 7. leucotis. Rüppell. MSS.

Senegaleusic, West. Af.

pl. 31. (head.)

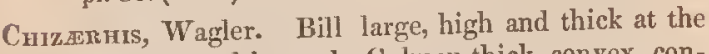
base, compressed beyond. Culmen thick, convex, considerably arched. Lower mandible not half so high as the upper: the tips of botll deeply notched, with their margins finely crenated. Nostrils basal, placed close to the top of the bill, naked, lunular, and pierced in the substance of the bill. Wings lengthened; the four first quills graluated. Tail lengthened, slightly rounded ; the tips very obtusc. Feet as in Corythaix. C. variegata. W. Af. i. pl. $20 . \quad$ zonura. Rüpp. MSS.

Musophags, Isart. Bill resembling that of Chizarhis : but the base enormously dilated, so as to spread like a casque or lielnet over the fore part of the head as far as the crown, where its thickened sides form a semicircle. Nostrils naked, oval, opcn, placed nearer to the tip than to the eyes, and pierced in the substance of the bill. Wings, feet, and tail as in Corythaix.

M. violacea. Isart. West. Af. i. pl. 19. 


\section{FaMILY BUCERID E. Hornbills.}

The eharacters of this family are those of the only genus. Buceros, Linn. Bill enormous, generally furnished with protuberanees of different shapes at the base of the upper mandible, beyond whieh the bill is much compressed, and both mandibles eurved downwarls; the margins entire. Nostrils lateral, basal, very small, oval, or round, and almost naked. Wings short or moderate, rounded. Tail rather lengthened ; the featleers narrow at their base, and obtuse at their tips. Feet short. Middle toe as long as the tarsus; Iateral toes unequal, the outer united to the middle as far as the first joint; hinder toe shortest. Claws short, thiek. The following speeies have been chiefly enumerated' M. Temminck : -

B. rhinoceros. Pl. Enl. 934. cineraceus. Tem. Nepal. monoceros. 1b. 873. lunatus. Pl. Col. 546. cassidix. Ib, 210. Abyssinicus. PI.Enl.779. hydrocorax. Ib. 283. galeatus. Ib. 9.89 . cavatus. Shaw. Malabaricus. Raff. galeatus. L. T. xiv. p. 578. pucoran. Raff. gracilis. Pl. Col. 535. convexus. Ib. 530 . elatus. PI. Col. 521. f. 1. exarhatus. Ib. 211. cylindricus. Ib, 521. f. 2 . sulcatus. Ib. 69. galeritus. Ib. 520. antracicus. Ib. 529. corrugatus Il. 531. comatus. IRaff. Pl. Col. Malayanus. Ib.

buccinator. Ib. 284. Panayensis. Pl. Enl. 780, 781. nasutus. Ib. 890 . erythrorhynchus. Ib. 260. Nepalensis. Hod joson.

\section{Tribe III. SCANSORES.}

Fanity RAMPIIASTIDE. The Toucans. Bill enormous, vascular within; the margins serrated. Wings short, rounded. Feet with two toes before, and two behind.

Rampiastos, Linn. Bill smooth. Nostrils cntirely coneealed, and placed at the edge of the thiekened frontlet of the bill. Wings short, rounded; the four 
outer quills graduated and abruptly pointed. Tail short, rounded.

R. magnirostris. (Toco Auct.) Pl. Tucanus. Pl. Enl. 307. Enl. 82.

Prenocrossus, Illiger. Bill smooth, less compressed. Nostrils vertical, naked, round ; pierced on the upper surface of the bill, on the edge of the frontlet. Wings sliort, rounded. Tail lengthened, graduated. P. aracari. P1. Enl. 166 .

Auracorxncuus, Gould. Bill considerably attenuated; furnished with longitudinal grooves on the sides, Nostrils latcral, placed in a furrow, and on a line with the eyes. Rictus or gapc wide, extending to beneath the eye. WVings rouuded. Tail graduated.

A. sulcatus. Sw. Zool. 11l. i. 44.

Scyтnizors, Latham. General structure of Pteroglossus; but the margins of the mandibles are without teeth. Wings long; the two first quills graduated; the third longest. Tail long, graduated. Australia only.

S. Australis. White's Voy. pl. 5 .

'Family PSITTACIDAs. Parrots.

Bill very short: the upper mandible grcatly curved over the lower, which is considerably shorter.

Surfam. MACROCIRCINZ. Macaus.

Upper maudible greatly hooked; lower mandible much higher than broad. 'Tail very long, cuneated. Macrocurcus, Vieillot. Size large. Orbits, and sometimes the face, destitute of feathers. Nostrils concealed. Notch in the upper mandible obsoletc; the under remarkably short, but very deep.* ( $f y$. 269.)

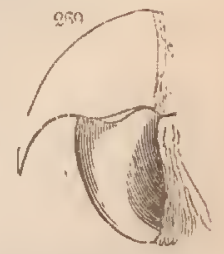

M. tricolor. Kuhl. Le Vaill. pl. 3.

The true characters of the suhtypical group I am not sufficiently acquainted with; but 1 am led to believe it is represented by these macaws which have the upper mandible conspicuonsly toothed, and the cheek: more or less naked. 
Conurus, Kuhl. Size much smaller. Upper mandible distinctly toothed. Orbits naked. Under mandible deeper than in its length. Four first quills the longest. America only.

C. vittatus. Spix, i. pl. 21.

chrysoplarys. Part 5. No. 120. macrognathus. Spix, i. pl. 25. (aberrant.) (fig. 270.)

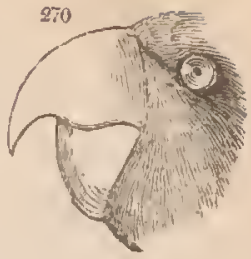

Lвptorynonus, Sw. Bill slender: tle upper mandible very slightly curved, considerably prolonged, and obsoletcly notched. Nostrils concealed. South America.

L. ruficaudus. Lear. Psitt. pl. 11.

Parasonnis, Vigors. Under mandible small, scarcely deeper than it is long; the upper distinctly toothed; the tip acute. 'Tail very long, cuneated; the feathers narrow, almost linear, and with their tips obtuse; the two middle greatly exceeding the others. The Old World.

P. torquatus. Le Vaill. pl. 22.

Sunfan. PSITTACINA. Parrots.

Upper mandible very distinctly toothed; lower mandible longer than it is high. Tail short, even or rounded. Envтunosтonus, Sw. Tail rather lengthened, graduated, or rounderl; the feathers broad. Wings moderate, resembling those of the next genus; but the tertials are not longer than the secondaries. Asia, Anerica.

macrorynchus. LeVaill.pl. 35. cyanogaster. Part 5. No. 180.

CHrysotrs*, Sw. Amazonian P'ar rots. Face plumed. Wings rather short; the first and second quills graduated, and shorter than the third and fourth, which are the longest; all these have the inner web

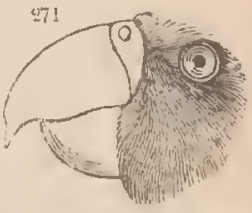

- In allusion to the yellow colour on the ears or face of nearly all the specier. 
sinuated in the middle: tertials very long. Tail short, longer than the wings, broad, with the tips rounded. America only. (fig. 271.)

Amazonicus. LeVail. pl. 84. restivus. Le Vail. pl. 110.

Dufresnii. Ib. 91. pulverulentus. Ib. 92. ochropterus. Ib. 98. zanthocephalus. 1b.98.bis. sordidus. Ib. 104. signatus. Ib. 105. cyanotis. Ib. 106. leucocephalus. Ib. 107. autumnalis. Tb. 111. Havanensis, Ib. 122. festivus. Ib. 129. cyanoceptal us. Ib. 135 . columbinus. Spix, i. 37. Xanthops. Ib. i. 26. menstruus. Ib.114. (aberrart.) And several new species.

Psittacus*, Linn. Wings lengthencd, nearly as long as the tail. Face (typically) naked. 'Tail even; the feathers rounded. 'The old World.

P. erythacus. Le Vaill. pl. 99.

Agafornis, Selby. Size diminutive. Under mandible very thick. Wings long, but shorter than the tail ; the three first quills equal and longest. Tail short, rounded; the feathers lanceolate, pointed. South America only.

A. cyanopterıs. Purt 5. No.118. Guianensis. Part 5. No. 119.

Porcephurues, Sw. Wings vary long, reaching to the end of the tail; the first quill scarcely shorter than the second ; the inner web of the threc first primaries suddenly narrowed beyond the middle, and then obliquely truncatcd at the tip. Tail very short, even; the feathers broad, truncate, but the shafts prolonged into mucronate points. Tropies of the Old World only: representing Palcornis.

Senegalensis, LeVail. pl. 116. aureus. Le Vaill. pl. 138. Geoffroyi. Ib. 112. melanocephalus. Ib. 119. pileatus. Ib. 1.9s. Barrabaudi. Ib. 134. Swinderianus. Lear. Psitt. pl. 42. torquata. Ib. 40. taranta. Ib. 39.

* In this genus, which I think is the most typical of the Psiltacina, I propose to retain, for the present, all those parrots of the Old World, which will not arrange under the next group. 


\section{Subam. PLYCTOLOPHIÑ⿺. Cockatoos.}

Head large, ornamented with a folding or procumbent crest. Bill short, very broad; the culmen remarkably curved. Tail rounded, lengthened, broad; the feathers not narrowed.

Plyctoloruus, Vieil. Head with a folding crest. Base of the under mandible (fig. 272.b) frequently concealed by ficathers, which theu makes it appear higher tlian it is
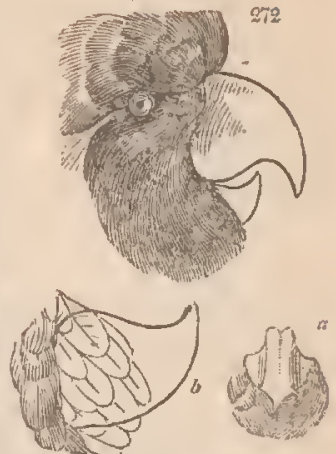
long $(a a)$. Wings long; secondaries, tertials, and sometimes the tail feathers, mucronate. India, Australia. Subtypical.

P. erythropterus. Lear. pl.5. galeritus. Ib, 3. sulphureus. Ib. 4. galeat us, Lath. G.II.pl, 28. rosaceus. Lear. pl. 2.
Cookii. Kuhl. pl. s.

Banksii. White's Voy.

Solandri. Lin. Tr. xiii. 113. funeralis. Shaw. N. M. 186.

? Baudinii. Ĺest. pl. 6.

Lrcmeris, Wagler. General structure of Plyctolophus, with the bill of Leptorynchus. ${ }^{*}$ The tenuirostral type.

L. tenuirostris. Kuhl. Pl. Col.

Microguossus, Geoffroy St. Hilaire. Cheeks naked. Heal large. Crest of narrow procumbent feathers. Bill very large ; the upper mandible enormous, doubly sinuated, and prolonged into un acute hook; the lower very short, but of great depth: the culmen almost perpendicular. Tail short, even. Tongue retractile, small, cylindrical, terminated by a thickened gland. India. Typical.

M. aterrinus. Le Vail. pl. 12, 18. griseus. Le Vail. pl.1!.

* Not having a specimen of this bird before me, I merely indicate the typical characters. 
Centrourus, Sw. Size large. Bill as in Microglossus; butsmaller. The under mandible is horizontal and porrect, as in Lorius, with the gonys not curved. Nostrils tumid, naked; the aperture central and round. Tail rather short, cren, or slightly rounded. The feathers broad, but ending abruptly in a lengthened, soft, acuminated point. 'The rasorial type.

Australis. Shaw. M. L. p. 87. ? dasyptilus. Les. Ill. pl. 1.

SUbFam. LORIANAr. Lories.

Bill but slightly curved: the margin of the upper mandible sinuated; the notch obsolete: lower mandible slender, conic, much longer than high: the gonys (typically) straight.

Brotogeris, Vigors. Bill as in Trichoglossus: the commissurc sinuated; but the margins without teeth. The lower niandible perfectly straight, conic, and without any curve on the gonys. Tongue tipt with a circle of rigid filaments. Head generally crested. Wings very long and pointed, reaching to the tail; the first quill rather shorter than the two next, which are equal and longest; the rest rapidly diminishing: scapular quills shorter than the secondaries. Tail moderate, graduated; the feathers broad; the tips narrowed. Size small. Australian Islands only?

sappherinus. LeVail. pl.65. Kuhlii. Zool. Jour, i. pl. 16. (Sparmanni, theyoung of do.) pyrrhopterus. Ib. ii. 394. porphyrocephalus. Shaw.

Le Vail. p.. 7 i.

Pstrmacur.rs, Khul. Upper mandible distinctly notched, much prolonged, and very slightly curved; under mandible short: the gonys curved. Wings pointed; the first quill longest. Tail very short, even; the feathers broad, and their tips obtuse.

P. vernalis. Z. Ill. ii. pl. 1.* rubrifrons. Lear. Psitt. galgulus. Pl. Enl. 192.f.2. pl. 41.

* 'The bill in this species is bright red, in galgulus it is deep black. 
'Trichoglossus, Vigors. ( $f i g$. 273.) Bill compressed : the upper mandible much hooked; the margin without a notch: under mandible lengtlened; much longer than decp. Wings pointed ; the three first quills equal; tertials longer than the secondaris. Tail long, cuncated ; the feathers narrowed throughout. T. Swainsonii. Le Vaill. pl. i. pl. 24. Zool. Ill. ii. pl. 92. Lorivs, Brisson. Bill as in Trichoglossus. Wings pointed. The two first qullls the longest. Tail moderate, rounded, or graduated; the feathers broad, and hardly narrow at their tips.
L. garrulus, Z. IIl. ii. pl. 12.
Isidorii. Z. III. ii. pl. 8

Prranodes, Sw. Bill and general structure of Lorius. Tail cuneated, very long; the feathers narrow and pointed; the two middle pair greatly exceeding the others. Indian Islands: representing Palcooruis.

P. papuensis. Le V:till, i. pl. 77.

Sumam, PLATYCERCINE. Loriets.

Tail long, very broad, considerably cuncated. Bill strong, thick, toothed: the culmen very convex. Under mandible deep, but very short: the gonys eurved. Feet and toes slender. Tarsus longer than the hallux.

Vigonsis, Sw.* General structure of Platycercus. Orbits naked. 'Tail lengthened, even, or slightly rounded; the feathers broad throughout. Rasorial.

V. vasa. Le Vaill. pl. 8I. niger. Le Vaill. pl. 42.

Pratycencus, Horsfield and Vigors. Tail cuneated, re-

- I wish to name this interesting group, of which I only know the tynical diatiuctions, in eonmemoration of the excellent ornithologist who first defined, and ably illustrated, many of the groups in this family; and whese efforts towards determining their nalural arrangement have been conducted on sound philosophical princlples. I hare adopted nearly all the genera proposed by Mr. Vigors, simply because I have found them natural. Those of M. Wagiler I have totally rejected : they are not betier than $\mathrm{M}$. I.esson's, and have llacteforc no claim lo a preference, evell on the score of bare priorty: they seen to me, in short, highly artificial and altokether inadmissible. I suspect that in Vigorsia the tail fenthers terminate in fine noints (althouph I have not a spetimen fo refer to), bpeause I view it as the rasorial typc of this circle, rcpresenting the Plycloiophinct 
markably broad; the feathers wide, slightly narrowing towards their tips, which are obtusely rounded. Wings rather short, eonvex; the outer web of four of the primaries suddenly dilated near their base. Under mandible somewhat angulated.

P. scapulatris. Zool. IIl. ii. pl. 26.

Naxodes, Horsfield and Vigors. 'Tail cuneated; the feathers narrow and pointed. Wings rather lengthened ; the first quill equal to, or rather longer than, the seeond; the others rapidly diminishing; tips of the secondaries obliquely truncated. Under inandible not angulated. Fect as in Platycircus. Subtypical. N. discolor. Z. Ill. i. pl.69. venustus. Z. Ill. ii. pl. 21 .

Leptozoputs, Sw. TVings very long; the first quill rather shorter than the seeond, whieh is the longest; the rest rapidly diminishing. Tail long, very broad; the lateral feathers narrowing at their points, but the two middle considerably pointed, and extending much beyond the others. Tarsus shorter than the hallux. Nostrils large, tumid, naked; the aperture round. The fissirostral type.

L. auricomis. 'Zool. I1l. ii. pl. 112. Lear. pl. 27.

Pezoponus, Illiger. Upper mandible with the margin arched and entire; lower much thieker and stronger. Tail long, cuneated; the feathers narrow and pointed. Tarsus much lengthened. Claws very slender. The grallatorial type. (fig. 274.)

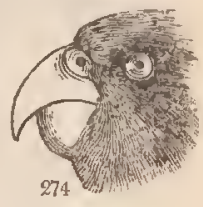

P. formosus. Shaw's Zool. of N. H. pl. 3.

FanmY PICIDEA. The Woodpeckers.

Bill straight, more or less eonie. Toes placed in pairs.

Sublam. PICIANZE. The True Woodpeckers.

Bill wedge-shaped. Tongue vermiform.

Picus. Typical Woodpeckers. Bill perfeetly wedge-shaped, eylindrieal: the culmen straight: lateral ridges re-

voL. II. 
moved from the culmen. Versatile toe always longer than the anterior.* ( $f g .275$.
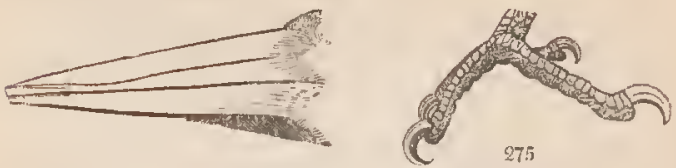

Picus, Sw. Lateral ridge situated nearer to the edge than to the culmen. Bill with the sides compressed. Neck long, and thin. Versatile toe considerably lengthened. America and India.

P. robustus. Spix, pl. 44. principalis. Wilson, 29. f. 1. Hemicircus, Sw. Tail excessively short, and very broad. Neck short, very slender. Bill straight, considerably compressed. Lateral ridge slight, near to the margin. Nostrils concealed. Feet very large. Versatile toe always longer than the anterior. Wings nearly as long as the tail. India.

\section{II. cuncretus. Pl. Col. 90.}

Dendrobates, Sw. Lateral ridge close to the margin. Sides of the bill much compressed; the base wide. Versatile toe usually longer than the anterior. Plumage, olive above, generally spotterl or banded. Africa only *, excepting two species from Tropical America. D. fulviscapus. Ois. d'Af. pl, 253.

Apternus, Sw. Lateral ridges close to the margin. Bill rather broader than high. Feet three-toed; the two anterior nearly equal, the posterior much longer. Arctic

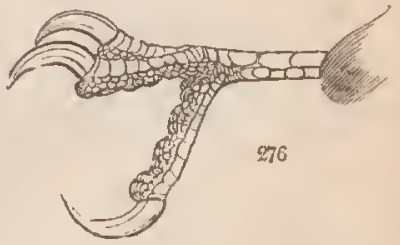
regions. ( $\mathrm{fg} .276$.

A. Americanus. N. Zool. pl. 56.† arcticus. N. Z. pl. 57.

* I use these terms for the sake of brevity: the versatile toe is the outer posterior toe, and the anterior is the outcr fore toe, corresponding to the midile vie of ordinary peckers.

+ I: being now ascertained that this is a distinct species from the Luropean tridaclylus, another name is necessary to desiguate it. 
Dendrocopus, Sw. Lateral ridges close to the margin. Bill as broad as it is high, the sides not compressed. Versatile toe much longer than the anterior, which latter is but slightly longer than the inner toe. Plumage black, spotted, or banded with white above, and plain bcueath. Universal.

D. major. Selby, pl. 38. f. உ. brunifrons. Gould's Cent. minor. Ib. pl.s8. f. 3. Marattensis, \&c. \&c.

Macei. Pl. Col. 59. f. 2.

Curysoprruus. Green Woodpeckers. Versatile and anterior toes of equal length. Lateral ridge nearest to the culmen, which is sharp, and either quite straight or very slightly bent. Bill depressed or widened at the base. Colour green, banded or spotted with black. Subtypical genus.*

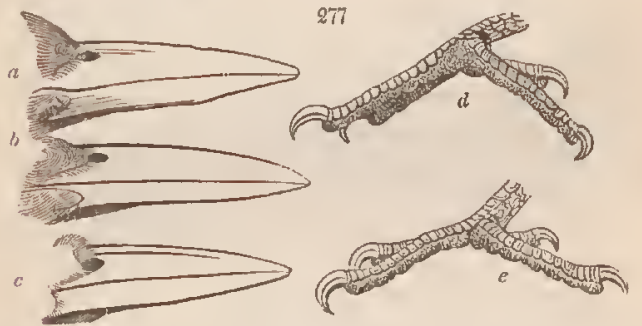

Dendromus, Sw. Lateral ridge slight, very close to the culmen, which is perfectly straight. Sides of the bill compressed. Plumage olive. Africa and India. D. brachyrynchus. W, Af, ii. punctatus. Wagler. sp. 37.

Chloronerpes, Sw. Lateral ridge strong, well defined, and placed nearly half way between the culmen and the margin. Culmon quite straight. Versatile toe shortel

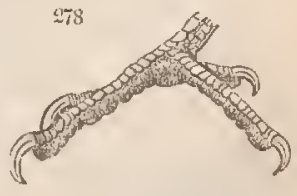

* I do not frel confident that the subgenera in this division are placed in their true series; but Dryotomus certainly enters into this, rather than into the last genus; and 1 look upon the $l$. Cimpestris as naturally allied to this group, rather than to Colaptes. 
shorter than the anterior. ( $f g .278$.) Neck slender. Tropical America only.

C.rubiginosus. Z.I.i, pl.14. macrocephalus. Spix, 53. f.2.

Dryotomus, Sw. Lateral ridge nearer to the culmen than to the margin. Bill very straight, widened on the sides, and broader than it is high. (fig. 279.)
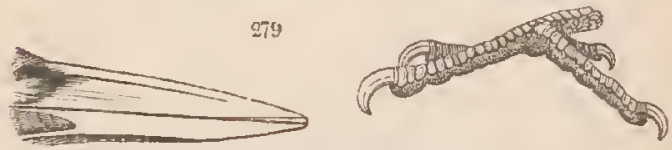

Versatile toe much shorter than the anterior. America and Europe. P'lumage black and white: representing Picus.

D. pileatus. Wilson, pl. 29. f. 2. lineatus. Spix, pl. 48.

Chrysoptilus, Sw. Lateral ridge slight, very close to the culmen, which is somewhat curved. Versatile toe as long as the anterior. Tropical America.

C. Cayennensis. P. Enl. 613. guttatus. Sp. i. pl. 53. f. 1. Campestris. Spix, pl. 46.

Malacolophus, Sw. Rasorial Woodpeckers. Versatilc toe shorter than the anterior. Culmen eurved. The lateral ridge (except in the typical group) wanting. Tarsus shorter than the versatile toe. Hind head with a crest of very soft feathers.

Brachylophus, Sw.* Nostrils covered. Neck thick. Bill widened its whole length. Under mandible thickened at the base, with one or more slightly elevated lines (representing the lateral ridge) close to the culmen, which is arched. Gonys very slort. Hind bead with a shortened, narrow, pointed crest. Versatile and anterior tocs nearly equal. Tarsus shorter. 'The Old World only. Rasorial.

B. viridis. Selby, pl. 38. canus. Edwards, 65. miniatus. Auct. occipitalis. Gould, Cent. pl.47. squamatus. Ib. 48 . dimidiatus. Pl. Col. 501 .

* Connected to Chrysmptilats by B. puricerts, and to Chrysonotus by B. he. mipodius (Bengalensis Auct.), which completes the circle. 
Hemilophus, Sw. Size large. Neck long and slender. Lateral ridge prominent and close to the culmen, which is very sharp and slightly arched. Gonys hardly half the length of the under mandible. Anteterior toe much longer than the versatile one. Hind head with a short compact crest. Wings and tail long, India only. Typical.

1. pulverulentus, Pl. Col. 389.

Malacolaphus, Sw. Neck slender. Head with a lengthened crest of soft, loose, long feathers. Nostrils naked; the aperture oval. Bill broad at the basc, mucli compressed beyonel. Culmon curved, and very sharp. Lateral ridge (typically) wanting. Anterior toe longer than the versatile toe. Tropical Ancrica only. Subtypical. ( fig. 277. $a, d$ )

M. cinnamomeus. PI. E. 524 . castaneus. Spix, i. pl. 47. ochraceus. Ib. 51. f. 1 .

flavicans, Pl. E. 599.* flavescens. Spix, i, pl. 49. undatus. Edw. pl. 332.

Meiglyptes, Sw. Bill thick and broad at the base, as in Melurerpes. Culmen considerably arched; the sides much rounded, and somewhat cylindrical. Lateral ridge wanting. Wings long. Versatile and antcrior toes equal. Tarsus slightly shorter. India. Fissirostral.

$$
\text { P. poicilophus. PI. Col. 197. f. } 1 .
$$

Chrysonotus, $\cdot \mathrm{Sw}$. Bill as in Brachylophus; but the sides compressed, and the lateral ridge entirely wanting. Fect with only three toes. India only. Grallatorial: representing Ayternus.

C. tridactylus. Lin. Tr. xiii. 177. (P. tiga $\Lambda$ uct.)

Colaptrs, Sw. Tarsus leugthened, and equal to the versatile toe; which latter is shorter than the anterior. Bill broader at its base than it is high; the sides compressed : the culmen considerably curved from its base; the lateral ridge either obsolete, or entirely wanting. Nostrils partially defended by feathers. Geocolaptes. Burchell, MSS. Bill as in Colaptes,

* The connecting link to ILmilophus, as having the lateral ridge of that group. 
but with a faint lateral ridge close to the basal half of the culmen. Tip of the upper mandible wide and depressed. Wings very short. Tarsus, anterior and Fersatile toes, all of the same lcngth. Africa only.

G. terrestris. Burchell. Ois. d'Af. pl. 264.

Colaptes. Bill considcrably compressed. Culmen arched from the base. Lateral ridge entirely wanting. Tarsus longer than the versatile toe. Wings long. (fig.277.b,e) C. auratus. Wils. pl. 3. f. 1. Mexicanus. N. Zool. ii. 315. Metanenpes, Sw. Bill straight, more or less cylindrical : base wide: the ridge of the culmen slightly bent, but not very prominent: the sides rounded; the lateral ridge slight, and placed near, but not close to, the culmen. Gonys very long, as in the typical group. Nostrils nearly concealed. Wings long; the first quill spurious, or very small; the second nearly as long as the third. Toes various. Habits gregarious and migratory. Colours black, varied with white and red. The fissirostral type. America only.

Centurus, Sw. Cronys angulated, half as long as the under mandible. Lateral ridge alsont half the length of the culmen, which is gently curved. Sides of the bill compressed. Tarsus shorter than the versatile toe; the antcrior rather longer. Plumagc, above, black banded with white. (fig. 277.c)

C. Carolinensis. Wils. 7. f. 2. brachypterus. Sw. sp. nov.

reuconerpes, Sw. 13 ill as in Melanerpes. The base wide, but the sides much compressed. Lateral ridge placed half way between the culmen and the margin. Wings long. Versatile toe shorter than the anterior. Tarsus sliorter than either.

L. candidus. Zool. IHI. i. pl. 38.

Melanerpes, Sw. Bill straight, the base wide; the sides not compressed. Gonys long, and equally curving to the tip with the culmen. Versatile and anterior toes equal. Tarsus much shorter. Wings long, reaching almost to the end of the tail.

M. erythrocephalus. WiIs. 9. f. 1. torq̨uatus. Ib. 20. f. 3. 
Tripsurus, Sw. Bill as in Leuconerpes; but the nostrils are thickly covered with incumbent bristles, as in the typical genus Picus. Feet very large; but the versatile and the anterior toes are of the same length. The tarsus considerably shorter than either.*

T. flavifrons. Spix, pl. 52.

Sturam. BUCCOIN $\mathbb{E}$, Barbuts.

Bill surrounderl with long bristles. Tail short, soft.

Asthenurus, Sw. Bill short, compressed, very straight. Rictus smooth. Wings with the three first quills graduated. Tail moderate. Versatilc and anterior toes nearly equal. Tropical America.

A. exilis. P. Col. 371, f. 2 . cirratus. P. Col, 371 . f. 1.

Picunnus, Tem. IIabit of Asthenurus; but the rictus is bristled; the tail very short, and not projecting beyond the wings. Tropical Asia.

P. abnormis. Pl. Col. 371. f. 3.

Bucco, Linn. Bill straight, strong; the base very broad, dilated, and surrounded with long and very rigid bristles. Tarsus shorter than the versatile toe. 'The old World.

B. philippensis. P1. Enl. 381. chrysoptera. Part 5. No. 125.

Micropogon, Tem. General structure of Bucco; but the gape smooth. The three first quills only graduated. South America only.

II. Cayennensis. Pl. Enl. 206. f. 1.

Pogonias, Ill. General structure of Bucco; but the margin of the upper mandible distinetly toothed. Africa only.

P. sulcirostris. Z. Mis. pl.76. (lavirostris is the young bird.)

Yuxx, Linn. Bill short, slender, very straight; base widened. First quill nearly as long as the second.

* This type is united to that of Dendrocopus by means of $D$. varia, - a * This type is united to that of Dendrocopus by means of D. and which
bird which has the bill of Dendrocopus, and the teet of Tripsurus, a Melaner-
thus closes the circle of the Piciune. The tenuirostral type of Micus meropes I have not seen; but I have little doubt of its being the Picts meropirostris of Wagler, sp. 65. 
Feet as in Bucco. Tail moderate, broad, even. The Old World.*

Y. torquilla. S.1by, pl. 38. f. 4.

Oxyrynchus, Tem. Bill as in Iunx; but the culmen more, and the gonys less, curved. Wings lengthened, pointed; the first quill nearly as long as the second, with the outer web crenated. Feet short, insessorial. Lateral toes equal. Tail moderate, even. South America.

O. cristatus. Zool. Ill. i. pl. 49.

\section{Famis CERTHIADA. Creepers.}

Bill much compressed, entire. Feet insessorial. Toes greatly developed, and generally united at their base; the hinder always lengtliened. Tail cuneated, rigid.

Sublam. CERTHIAN E. True Creepers.

Bill generally curved, and greatly compressed. The anterior toes more or less united. Tail rigid, with the shaft projecting beyond the webs. The typical division. Centrira, Linnæus. ( $f g$. 280. $a, b$ ) Bill lengthened,

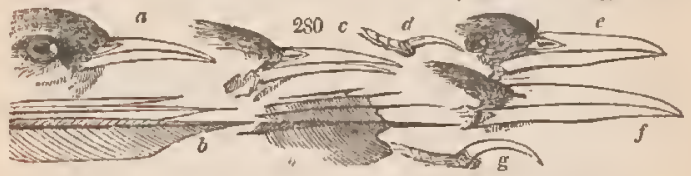

slender; both mandibles curved, entire. Wings rather lengthened; the three first quills grarluated; the two next equal and longest. Tail lengthened, graduated, and divaricated; the feathers only slightly rigid, lanccolate, and acutcly pointed; the tips not very stiff. Legs short, slender. The middle toe longest; the inner much shorter than the outer; hinder toe longer than the tarsus, the claw very long, and but slightly curved. All the claws vcry slender. The fissirostral type. Europe, America.

C. familiaris. Selby, pl. 39. f. 2 .

* This and the next genus appear representatives of two subfamilies. 
Oxyurus, Sw. (fig. 280.c) Bill short, straight, very slender, resembling that of a Sylvia; the sides compressed, and the margin inflexed: the tips entire. Wings rather lengthened; the outer quills graduated, the fourtl and fifth equal. Feet large. Middle toe of the same length as the hiniler ; lateral toes unequal, the outer connecterl to the middle as far as the first point; inner toe shortest. Tail graduated, rigid: the inner web broad, and abruptly sinuated at the end $(h)$; onter wcb very narrow : tips of the shafts hard and naked, as in Dendrocolaptes. S. America. O. ornatus. Part 5. No. 181. australis. Lath. Syn. iv. pl. 52.

Dennnocondptes, Illiger. Bill of various forms. Feet short (fig.75. Vol. 1. p.139.). The outer and middle toes of equal length, and connected to the first joint; inner toe much shorter, almost free; hinder toe equal to the inner. Anterior claws equal; hinder larger. Tail euneated, very stiff; the tips of the shafts hard, horny, and aeute. Tropieal America only.

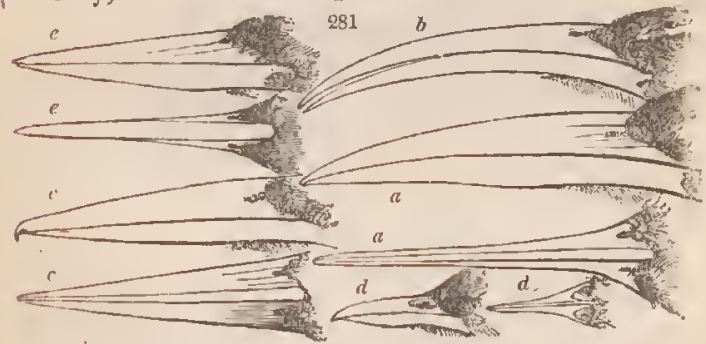

Dendrocolaptes proper. (fig. 281. a) Bill lengthened, strong. Culmen slightly arched, and gradually inelined to the tip; the sides compressed the whole length from the nostrils. 'Tarsus short, strong. 'Two external toes longer than the tarsus; linder toe slightly shorter. The eonirostral type.

D. decumanus. Spix, i. 37 .

Ziphorynchus, Sw. (fig.281.b) Bill lengthened, slender; both mandibles considerably eurved, typically falcated ; 
the sides compressed from the nostrils. Wings rather lengthencd; the second quill hardly shorter than the third. Tarsus short, slender, of equal length with the two external toes. Hinder toe shorter than the tarsus. Tongue cartilaginous, flat, as long as the bill. The fissirostral type.

Z. procurvis. Pl. Col. 23 . birittatus. Spix, i.90. f. I.

Dendrocops, Sw. ( fig. 281.c) Bill lengthened, nearly straight; the sides widened, quadrangular; the base broader than high: the tip of the upper mandible abruptly deflexed over that of the lower, and obsoletely notched. The dentirostral type.

D. platyrostris. Spix, i. 89.

Sittasomus, Sw. (fig.2S1.d) Bill short, weak, resembling that of a Sylvia; rather willened at the base, beyond which the margin of the upper mandible is inflected. The hind claw is longer than the toe, and nearly straight. The tenuirostral type.

$$
\text { S sylviellus. PI. Col. 72. f. } 1 .
$$

Dendroplex, Sw. (fig. 281.e) Bill moderate, very straight, perfectly conie in profile; the sides much compressed. Tongue very long, vermiform; extending, when thrown out, to more than twice the length of the bill; the tip hard, acute. The scansorial type.

1). guttatus. Spix, i. 91. f. 1.

Sct.frurus, Sw. (fig.76. Vol. I. p.42.) Bill lengthened, compressed. Commissure and under mandiblestraight. Culmen of the upper mandible bent towards the tip, and reflected over the lower, where it is distinctly notched. Wings moderate, rounded; the first and second quills graduated; the three next equal, and longest. Tail very broad, soft, and rounded; the tips obtuse, but with the shafts very rigid, and slightly projecting. Feet large, ratlıer strong. Middle toe longest, united to the outer for half its length; inner toe much shorter than the outer, connected at the base to the middle toe; hind toe and tarsus 
equal. Anterior elaws fully curved; hinder claw long, more straightened. South Am.

S. albogularis. Braz. B. ii. pl. 78 . ruficollis, Ib, ii. pl. 79. Funnarius, Vieillot. ( $f g .280 . f, g)$ Bill lengthened, more or less curved, muel compressed; the margins infleeted in the middle: the tip of the upper mandible bent over the lower, and entire, or with an obsolete notch. Commissure slightly curved. Nostrils large, depressed; the aperture naked and oval. Frontal feathers advaneing very far on the bill. Gape smooth. Wings rather short, rounded. Tail rounded, broad; the tips sometimes euspidate, rarely pointed, but always soft. Fect large, strong, ambulating. Lateral toes cqual, or very nearly so, and with all the joints frec. Claws noderatcly curved. Hinder toe and claw very strong; much longer than the lateral toes. South America only.

F. melanotis. Part 5. No. 132. leucopus. Part 5. No. 133.

griseus. 1b. No. 134 .

Subram. ANABATIN正. Tree-Runners.

Bill rather short, strong, straight. Tail cuneated and stiff; but the tips of the shafts do not project beyond the webs. Toes moderatc: middle toe always longer than the lateral; and all are more or less free. 'The subtypical division. S. Ameriea only.

Geовати, Sw. ( fig. 280.d,e) Bill short, straight, entire, resembling Synallaxis. Wings rather lengthened; the first quill rather shorter than the three next, which arc cqual, and the longest ; tertials broad, lengtliened, nearly as long as the primaries. Tail short, rounded. Feet slender, ambulating. Tarsi lengthened. Claws small, and but slightly eurved ( fig. 280. d). Lateral toes unequal; the inner shortest, and cleft to the base; the outer united to the middlc for half its length; hallux, or hinder toe, of the same length as the outer toe.

N. B. - The structure of the feet separntes this type from Furnarivs, which it seems to represent in this group.

G. brevicauda. Part 5. No. 126. 
Synar.uAx1s, Vieill. ( fig.282.b) Bill short, rather strong,

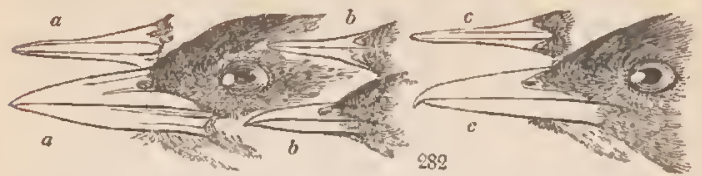

straight: both mandibles of equal thickness, entire, and much compressed ; the margins of the upjer inflexed beyond the nostrils. Frontal feathers rather rigid. Wings very short, and much rounded; the primaries scarcely exceeding the tertials. Tail broad, more or less lengthened, and either graduated or cu. neated; the webs soft and loose, but the shafts rather rigil ; the tips lanceolate. Feet very large. Tarsus lengthened. Niddle toe longer than the hinder; lateral tocs equal. Claws slender, acute, and but slightly curved; the three antcrior rather small.

S.garrulus, Z. Ill.i.pl.138. cinnamominus. Spix, i.pl.85.f.2.

Dennnoma, Sw. (fig. 282. c) Bill straight, entire, much compressed; the culmen straight, but the tip suddenly bent down and inflexed over that of the lower mandible. Wings moderate, rounded. Tail somewhat stiff, lengthened, graduated, and very obliquely pointed. Tarsus longer than the middle and the hind toes. Lateral toes unequal, the inner shortest; hind and middle toes of equal length. All the claws moderate and broad, and fully curvel. The toes more or less free.

D. caniceps. Braz. Birds, pl. 80.

Anarates, Temminck.* ( fig. 282. a) Bill strong, very straight, greatly compressed, conic when viewed in profile: the tip not inflexcd: the culmen and gonys equally inclining towards the tip. Commissure straight. Wings very short, rounded. Tail somewhat stiff, lengthened, graduated; the feathers broad, but with the tips pointed. Tarsus shorter than the

* This is not strictly Anabates of Temminck, who includes under that name three out of the live genera of this subfamily. 
middle and hind toes, which are of equal length. Lateral toes unequal, the inuer shortest, and both (typically) clcft to the base. Hinder claw very large; and all the rest fully curved.

\section{A. subcristata. Sw. Braz. Birds, pl. 81.}

Zenops, Illiger. (fig.74. Vol. I. p. 137.) Bill short; the culnen very straight; but the commissure, and particularly the under mandible, curving upwards. Wings rather lengthened, rounder. Tail moderate, rounded, slightly stiff; the feathers olstusely pointed. Tarsus very short. Middle and hinder toes longer than the tarsus; lateral toes uncqual, the inner shortest, and both slightly connected at their base; hinder toc shortcr than the middle; its claw shorter than the toe. The fissirostral type.

Z. genibarbis. Zool. Ill. i. pl. 100.

\section{Surfam. SIT'TIN AL. Nuthatches.}

Bill very straight, more or less cylindrical. Wings long, pointed; the first quill liardly shorter than the sccond. Tail very short. Hind toe as long as the middle. The fissirostral division.

Sittella, Sw. Bill very straight; the gonys curving upwards; the sides greatly compressed: tip of the upper mandible distinctly notched. Wings longer than the tail. Tail very short, even. Feet large, resembling those of Sitta. Australia.

S. chrysoptera. Lath. Supp. 2. pl. 127.

(ivosita, Sw. (fig. 283.) Bill longer than the head, trigonal at the base, cylindrical beyond. Culmen rounded. 'The tip' of the upper mandible entire, broader than high, and slightly bent over the lower. Wings long, pointed; the first quill nearly equal to the second and third, which 
are longest ; tertials lengthened. Tail slightly forked. Feet slender. Anterior toes rather short; the lateral ones unequal, the claws small; hind toe as long as the middle toe, but shorter than the tarsus; the claw much lengthened, and slightly curved. Chili.

\section{G. anthoïdes, Part 5. No. 129.}

Srrta, Linnæus. (fig.72. Vol.I. p. 136.) Bill moderate, very straight, cuneated, somewhat cylindrical ; the tip not deflexed, and entire. Nostrils entirely concealed by tufts of incumbent feathers. Wings long; the first quill spurious; the second slightly shorter than the third, fourth, and fifth, which are equal, and longest. 'Tail short, soft, even. Feet short, strong. Claws very large, particularly the hinder one; the tluree antcrior cleft to their base. Lateral toes very uncqual ; the outer one not much shorter than the middle, the inner very short: hinder toe much longer than the middle, and equal to the tarsus; the claw much shorter than the toe. All the claws strong, broad, and fully curved.

S. Europrea. Selby, pl. 39. Canadensis. Wils. 2. f. 4. Caroliuensis, Wils. 2. f.2. pusilla. Ib. 15. f. 2.

Dendropurua, Sw. General structure of Sitta; but the nostrils are large, oval, open, and almost entirely naked; the lase of the bill wiclenel; and the tip of the culmen is inclincd downwards. India only." D. Havipes. Part 5. No. 130. frontalis. Zool. I11. i. pl. 2. Cumacteks, Temminck. (fig. 73. Vol. I. p.136.) Bill moderate, very slightly bent, compressed, entire. Wings lengthened, rounded; the first quill spurious, the second and third graluated, the fourth longest. Tail very broad, soft, slightly rounled; the feathers obtuse. Feet short. Toes cnormously long : middle

* I do not believe that either of these two birds exhibit, in perfection, the typical characters of this genus, which, from theory, I suppose to intervene between Climacteris and siuta. I have, therefore, had some hesitation in proposing the group. The weaker structure of the bill, however, and the nakedness of the nostrils, prove that the habits of these Indian birds must be different from those of the more, powerful nuthatches, where the culmen is straight even to its very tip, and the nostrils are entirely concealcd. 
toe equal to the hinder; outer toe shorter than the middle, and connected to it at its base; inner toe much the shortest, almost frec. All the claws slender, and much curvied. Australia, 2.*

C. auricomis. Pl. Col. 281. mystacalis. PJ. Col. 335. f. 2. male; 1 . female.

Su BFAM. TROGLODY'TINAs. Wrens.

Feet with the tarsus longer than the hind toe, which is but slightly developed. Lateral toes nearly equal, and cleft to their base. The tennirostral division.

Pcatyunus, Sw. Bill mollerate, straight, compressed; very high at the base of the culmen, which is there slightly gibbous, and divides the frontal feathers. Upper mandible distinctly notcherl. Nostrils very large, basal, protectcd by a scalelike convex membrane. Frontal feathers stiff, setaceons, narrow, and sonetimes reflected forwarls. Wings remarkably short and rounded, very convex. Tail (typically) lengthened and graduated; the feathers very soft and broad. Fect very large. Middle toe as long as the tarsus; Iateral toes equal, and cleft at thcir base; hind toe shorter than the tarsus. All the claws compressed, and but slightly curved; the three anterior small; the posterior twice as long. South America.

P. conniculatus, Braz. B. pl.55. rubecola, Braz, B. pl. 14. affiuis. Ib. pl. 57 .

niger. Part 5. No. 128. lepturus. Kittlitz. pl.5.

Thevotuunus, Vieillot. Bill lengthened, much longer than the hcad, compressed, straight, or very slimhtly curved: the tip of the upper mandible slightly reflexed, and obsoletely notched; the base rather broad. Wings and tail moderate, rounded. Fect large, strong. 'Tarsus lengthened, much longer than the hind toe, but cqual to the midlle one. Lateral

* The authors of the $\mathrm{Pl}$. Col. have been singularly unfortunate in illustrating this genus : their $C$. scandens ant picumnus are only the sexes of one species (my auricontis); while their Melighaga mystacalis luas all the characters of a true climacteris. 
toes equal. Hind claw nearly double the size of the anterior ones: all the claws fully curved. America. Ludovicianus. Wils.pl.12.f.5. rutilans. Braz. B. pl. 14. striolatus. Braz. B. pl. 16. Mexicanus. Z. 11l. ii.pl. II. rectirostris. Z.11l. i. pl. 140. genibarbis. Part 5. No. 12\%

'Trogconytes, Linn. (fig.71. Vol. I. p.135.) Bill short, slender, compressed, like that of a Sylvia. Both mandibles entire. Wings vcry short, and rounded. Tail short, narrow, rounded. Legs moderate. 'Toes long; middle toe as long as the tarsus; lateral toes equal; hinder toe shorter than the tarsus. Anterior claws small, equal; posterior claw mucl larger: all the claws broad, and fully curved. Europe, America. T. Europaus. Selty, pl.47. f.5. equinoctialis. Braz. B.pl.13.

Loouma, Sw. Bill moderate, nearly straight; the culmen gently inclining towards the tip, which is entire; the gonys straight. Wings short, rounded ; the first and second quills graduated. Tail soft, short, slender, rounded; the tips ovate, but, with thc shaft, forming a fine soft point beyond the webs. 'Tarsus lengthencd. Middle toe longest; lateral toes much shorter, and very unequal ; the outer longest, and slightly connected to the middle; inner toe shortest, and cleft to the base; hinder toe shorter than tlic tarsus. All the claws slightly curved. Brazil. L. squamulata. Sw. Braz. Birds, i. pl. 33.

Trcnonroms, Illiger. Bill very long, slightly arched, cylindrical; the base angulated; the tip deprcssed. Nostrils naked. Feet long and slender. Exterior toe united to the base of the middle; hincler toe, with the claw, vcry long. Wings lengthened, broad; the first quill spurious, the second and third graduated, the tliree next longest. Tail short, round, broad, and soft. Europe.

T. muraria. Pl. Enl. 372.

SUвFAM. BUPIIAGINA. Oxpecker.

Bill very short. Tail moderate, rigid. Wings moderate. All the toes divided to their base. The scansorial division. 
BupnagA, Latham. Oxpecker. Bill thick, strong, slightly compressed: the inferior mandible much thicker than the upper, particularly at its base, where it is somewhat dilated. Culmen slightly elevated, and gradually arched from the base. Frontal feathers advancing to one half the length of the upper mandible. Wings rather long, and pointed. Tail cuneated; the feathers lanceolate and stiff. Feet strong (fig.78. Vol.1. p. 144.). Tarsus very short. Lateral toes equal. All the claws large, broad, and remarkably hooked. Afriea only.

B. Africana. Pl. Enl. 379 . erythroryncha. P. Col. 465. Ontuonvx, T"emminck. (fig.77. Vol.I. p.143.) Bill very short, straight, but the culmen arched from the base; the sides considerably compressed. Nostrils large, basal. Wings moderate, but considerably rounded; the four first quills graduated, and shorter than the fifth. Tail rather lengthened, rounded; the feathers very broad, and the webs soft, but the shafts stiff, very rigid, and terminating in naked points. Feet enormously large and strong. The outer toe rather longer than the middle, which is again longer than the inner toe; hinder toe shorter than the middle. Tarsus longer than either of the toes. Claws strong, very slightly curved; the anterior all of the same length; the hinder one longest. Australia only.

o. spinicaudus. I'. Col. 428,429 .

\section{Famity CUCULIDAs. The Cuckows.}

Bill slender. The external hind toe capable of being brought half way forward.

\section{Sobram. CUCULINA. Parasitic Cuckows.}

Wings pointed. Nostrils round. Bill slender, convex above. The tarsus very short. ( $f$ g. 284. )

Cuculus, Linn. (fig. 284. a) Bill broad at the base; the upper mandible obsoletely notched: culmen convex. Nostrils circular. Wings long, pointed; the third vol. 11. 


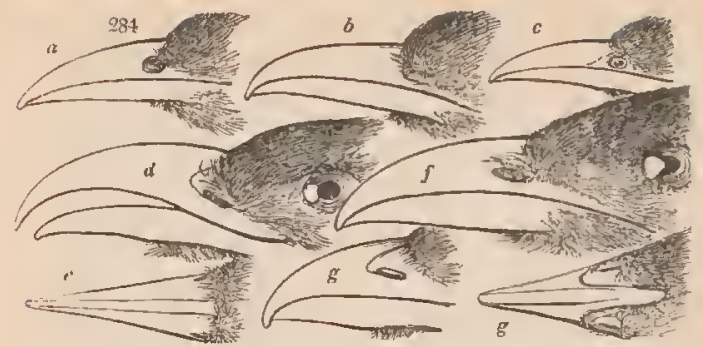

quill longest. Tarsus very short, feathered. The Old World.

C. canorus. Selby, pl. $45^{\text {****** }}$ f. 1.

Oxy Lophus, Sw. (fig. 284. b) Head erested. Bill slender, considerably and suddenly compressed from the nostrils, which are ovate: upper mandible entire. Wings moderate, rather pointed; the fourth quill longest. 'Tropics of the Old World.

O. Vaillantii. Z. Ill. ii. 13. edolius. O.d'Af. ₹. 207.

ERyтhropinvs, Sw. Head not crested. Nostrils oval. Wings lengthened, pointed, extending beyond the tail covers; the third quill longest; the seeond much shorter than the fourth. Tarsus moderate, naked. America : rear their own young.

E. Carolinensis. Wilson, iv. 23. f. 1.

Chadcres, Lesson. (fig. 28\% c) l'lumage shining metallic green. Bill and general strueture of Cuculus Tarsus very short, almost entirely plumed. Rump and upper tail eovers soft. The Old World.

C. auratus. O. d'Af, v. p. 210,211. Vaillantii. W. $\Delta$ f, ii.

Eunvasys, H. and V. Bill strong, thiek; the under mandible not eurved: the gonys distinctly angulated: upper mandible entire. Wings pointed. Feet very strong. 'The Old World.

E. orientalis. Pl. Enl. 274. f. 1. australis. Part 5. No. 189.

SurFam. COCCYZIN尼. Hook-billed Cuclows.

Wings short, rounded. Nostrils linear. Bill curved. 
Margins of the upper mandible dilated. Tarsus naked, lengthened. Tail very long, cuneated. Serisomus,Sw.( fig.285.)

Bill short, strong: the gonys thick, ascending, and angulated: the culmen thickened and arched. Tarsus and middle toe equal ; lateral toes unequal. Claws short. Africa.

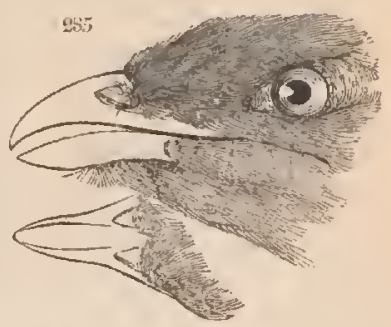

S. cristatus. Pl. Enl. 589.

Zanclostomus, Sw. ( fig. 284. $d, e)$ Bill much compressed its whole length. Gonys curved downwards. Culmen and upper mandible greatly curved; the basal margin considerably dilated. Wings, tail, and feet as in the last genus, but the lateral fore toes are nearly cqual. Tropics of the Old World.

Z. Javanicus. Horsf. Java.

Coccrzus, Vieillot. (fig. 284. $f$ ) Bill moderate, thickened at the base, compressed. Gonys straight. Basal margin of the upper mandible not curved outwards, and scarcely dilated. 'Tarsus and middle toe of equal length. Lateral fore toes unequal. America only.

C. cayanensis. Pl. Enl. 211.

Ptrolaptus, Sw. Wings very long. Bill intermediate in form between Coccyzus and Centropus. Nostrils long, linear. Feathers of the head and neck slender and rigid. Tarsus and middle toe equal; lateral toes unequal. All the claws curved, and of equal size. Tail of eight feathers. Habits terrestrial. Soutl America.

I'. cristatus. Vicil. Gal. pl. 44. ?

Centropus, Illiger. $(f i g .284 . g)$ Bill strong. Tarsus and middle toe equal. Anterior claws sleuder, slightly curved; hinder one very long, and nearly straight. C. Sencgalensis. Pl. Knl. 3932. Burchellii. Part 5. No. 128. 
SubFar. CROTOPHAGIN E. Hornbill Cuckows.

Crotopraga, Linn. Bill very broad on the sides. The culmen ligh, and forming an elevated ridge or keel which divides the frontal feathers.

sulcirostra. Part 5. No.124. rugirostra. Ib. No. 123.

levirostra. Ib. No. 122.

semisulcata. Ib. No. 194.

DAsvuophus, Sw. ( fig. 286. a) Bill rather large, compressed its whole length. Gonys angulated. Culmen convex, gradually arched. Frontal feathers incumbent, and concealing the nostrils. Feathers before the eye erect, forming a double crest.

D. superciliosus. Sw.

Phwnicopmaus, Vieillot. (fig. 286. c) Bill large, very thick, smooth, resembling that of a toucan in miniature. Face naked. Nostrils basal, oval, close to the rictus. placed in a groove of the bill, and defended by stiff erect bristles.

P. viridis. O.d'Af.pl.225. pyrrhocephalus. Vieil.Gal. pl.37.

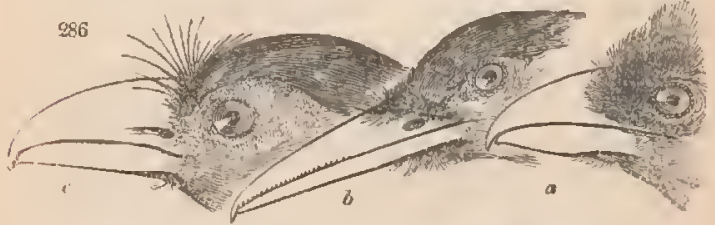

Surpan. LEPTOSTOMINA. Long-billed Cuckous.

SArrothers, Vieillot. (fig. 286. b) Bill lengthened, longer than the head, straight, except towards the tip : the culmen convex. Gouys straight. The upper mandible with its margins finely crenated. Orbits naked. Wings moderate; the second and third quills the longest. Feet slort. (Vieillot.)

S. velata. Vieil. Gal. pl. 38.

Anadenus, Sw. General structure of Saurothera; but the upper mandible is only notched at the tip: the margins entire. Wings much rounded; the four first quills grarluated. India.

A. rutescens. Part 5. No. 193. 
Leprostoma, Sw. Bill very long, entire. Wings very short, and rounded. Tail long, cuneated. Tarsus much longer than the toes. (fig. 172. p. 40.)

L. Longicauda. Sw. (1824). ? the Sauroth. Botte Blainv.

Surrasr. INDICATORINR. Honey Guides.

Bill short, subconic. Feet very short.

Inntcaton, Le Vaillant. Bill straight, filch-like; the base triangular; the sides compressed. Culmen and gonys equally inclined towards the tip; gonys angulated. Wings lengthened, pointed. Tail moderate, rounded. Fect short. Middle toe much longer than the tarsus.

I. major. O. d'Af.241. f. 1, 2. minor. Ib. 242.

flavirostris. I'l. Col. 367.

flavicollis. Vieil. Gal. 46.

Opistnoconus*, Hoffmanseg. Bill thick, robust, short, convex; the base laterally dilated ; the sides abruptly compressed : the under mandible strong. Gonys angulated. Nostrils placed in the middle of the bill, membranaceous. Feet robust, muscular. 'Tarsus shorter than the middle toe. Lateral toes long, equal, entircly cleft to their bases. Soles of the feet flat. The toe bordered by a rudiment of a nembrane. Wings moderate; the first quill very short, the four next graduated, the sixth longest. South America. (Tem.)

O. cristatus. ['l. Enl. 337.

Tribe IV. TenUiRostres. Suctorial Birds.

FamiLy MELIPHAGIDA:. Honey Suckers.

Bill the strongest in this tribe, having the upper mandible distinctly notched. Fect large, strong: the hinder toe much developed. Tongue extensible, generally ending in a bunch of filaments.

* The situation of this singular genus is very uncertain. From not having a specimen for close inspection, I have taken the above characters fron $\mathrm{M}$. Temminck. 
MelipinagA, Lewill. Bill moderate or short, weak: the under mandible not thickened. Lateral toes unequal; the inner the shortest. Tail rounded or graduated. Tongue bifid; each division ending in numerous filaments.

Meliphaga. Bill lengthened, as long or longer than the hearl. Wings rounded; the sixth quill longest. Middle toe longer than the hallux; the inner toe considerably shorter than the outer. Tail rounded. * M. barbata. Ois. dor. pl. 57. A ustralasiana. Ib. pl. 55.

Ptilotis, Sw. Bill short. Lateral toes almost equal. Tail slightly rounded, sometimes nearly even. Leads to Glyciphila.

P. Lewinii. Lew. Bds. pl. 5. lencotis. Lew. Bds. pl. 20 . Zanthomiza, Sw. Bill moderate, much curved: the culmen considerably arched. Face naked. Middle toe longer than the hallux. The tcnuirostral type.

Z. Phrygia. Shaw. Zool. of N. H. pl. 4.

Anthochtro, Horsfield and Vigors Size large. Bill short. The nostrils extending half way from the base. Lower jaw with naked caruncles. 'Tail long, graduated. Middle and hinder toes of equal Icngth. The rasorial type. $\uparrow$

\section{A. curunculata. White's Voy. pl. 6 .}

Guctenlis, Sw. Habit of Meliphaga. Bill either shorter; or slightly longer, than the head: the notch in the upper mandible far removed from the tip. Tongue rather short, terminated by numerous filaments. The third and three following quills longest, and nearly equal. Lateral toes cqual. Tail even.

G. fulvifrons. Lewin, N. H. Birds, pl. 22.

An'ruomiza. Habit of Meliplaga. Bill rather short. Tongue ——? Wings much rounded; all the

* The Certhia Nove Hollandice of the old a uthors, and of which the modern Meliphaga sericea, I am led to believe, is but a sexual difference.

+ I hardly think it advisable to discriminate these subordinate types by subgenerie names; but as that of Anthocharc has been already done, I have designated what appear to me to be three of the others : the ifth I am un. acquainted with. 
quills more or less terminating in points. Tail forked. Lateral toes equal. 'The fissirostral type.

A. coruleocephala. Mus. Carl. i. pl. 5.

Leprogrossus, Sw. Habit of Cinnyris. Bill remarkably long, slender, and curved. Tongue retractile, long, bifurcated, as in Trochilus. Lateral toes unequal. Tail nearly even. The tenuirostral type.

L. cuculkatus. Ois, dorés. pl. 60.

Pricoturus, Sw. Bill much lengthened, slightly curved: the upper mandible dilated, and folding over the base of the under; the margins of both inflected towards their tips. Nostrils lengthened; the aperture linear. Wings moderate, rounded: the first quill spurious; the four next very broad at their base, and cinarginate at the inner web. Lateral claws unequal. Tail very long, graduated; the middle feathers lax, and narrow. The rasorial type.

P. Capensis. Le Vaill. Af. vi. pl. $287,288$.

Maxonina, Vieillot. Bill short, robust: the under mandible thickened. Culmen arched, and much elevated from the base, considerably compressed its whole length. Commissure curved. Upper mandible notched near the tip.

M. viridis. Ill. of Om. pl. 78 .

Gymophrys, Sw. Bill short, subconic: the culmen scarcely curved; the sides compressed; the commissure straight. Notch in the upper mandible remote from the tip. Tail cven; lateral. Claws unequal.

G. torquatus. Lewin, N. H. Birds, pl. 24.

Eidopsarus, Sw. Bill moderate, subconic, depressed its whole lengtl, asin Sturvus. Culmen flattened, with the base advancing very far on the front. Commissure straight, bnt angnlated at its base.

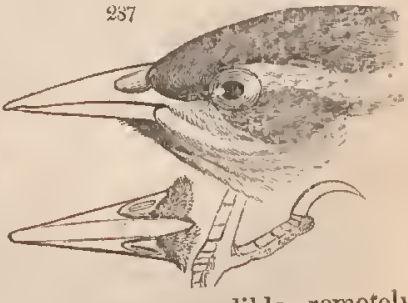

Upper mandible remotely y 4 
notched. Tail even. Legs pale. Lateral claws nearly cqual. Tongue as in Meliphaga proper. (fig. 287.) E. bicinctus. Part 5. No. 188. (fig. 2857.)

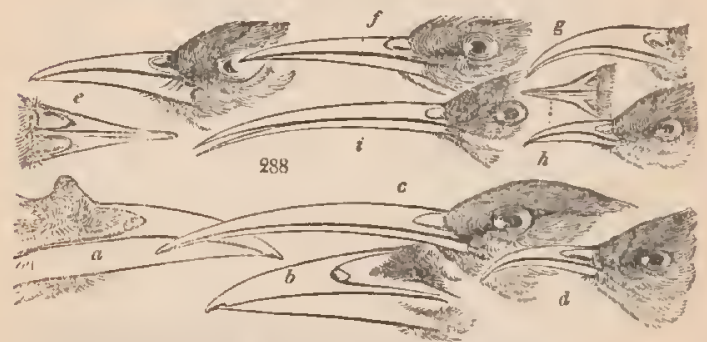

Evтомiza, Sw. (fig. 288. b) Bill strong, moderate: culmell inucl elevated. Nostrils large, naked; the aperture large, oval, and placel in the middle of the bill, at the termination of the naked membrane. Culmen obtuse, convex. Frontal feathers small, compact. Hind toe and claw very large, and as long as the midrlle toe.

E. cyanotis. Lewin, N. H. Birds, pl. 4.

Phulenos, Cuvicr. (fig. 288. a) Culmen sharp, carinated. Head and face naked. Front with an elevated protuberance. Hind toc and claw shorter than the middle. P. corniculatus. White's Voy, pl. 16. buceroïdes. Part 5.

Myzomela, Horsficld and Vigors. (fig.288.d) Bill with both mandibles very considerably curved; the sides broad, and nuch compressed. 'l'ongue and nostrils as in Meliphaga. Wings Icngthened ; the third, fourth, and fifth quills equal. 'Tail short, even. Middle toe mucl longer than the hinder lateral toes equal.

M. cardinalis. Lewin, N. H. Birds, pl. 19.*

Arachnoturra, Tem. (fig. 288. e) Bill very long, more or less curved : the upper mandible large, folding over and partly concealing the base of the lower mandible: the base broad, and three-sided; the tip

* Can this be the fifh subgenus of Meliphoga? or an aberrant Melthreptes? 
entirc. Nostrils small, oval, completely covered by a membrane, which only opens by a lateral semicircular slit. Wings long; first quill spurious, second and third graduated. Tail short, even. Legs large; strong. Lateral toes unequal. India only

A. flavigenis. Pl. Col. 388, f. 1.

\section{FamiLY CINNYRIDEE. Sunbirds.}

Wings with the outermost quills more or less shortened or graduated. Bill more or less curved, generally entire. Nostrils sliort, oval, membranaceous, opening by a lateral slit. Fect modcratc. Bill entire.

Mentmreprts, Vieillot. ( fig. 288.g) Bill long, sicklcshaped; the sides considerably compressed: the culmen elevated, and the tips entirc. Nostrils very short, opening by a semicircular slit. Tongue long; the tip only terminated by a bunch of short filaments. Wings moderate; the three first quills nearly equal. Feet robust, long. Lateral toes equal. Tarsus almost twice as long as the hind toe. Pacific Islands.

M. pracifica. Ois. dorés, pl. 63.

Cinnyres, Cuvicr. ( fig. 288. i) Bill long, slender; the tips very acute and entire; the margins minutely denticulated: base of the upper mandible folding over, and partly concealing that of the lowcr. Nostrils short, oval. Tonguc retractile, simply forked. First quill spurious, second shorter than the third. Tail even or rounded. India and Africa.

C. chalybea. Zool. 111. i. 95.

Anthrestes, Sw. ( fig. 288. $f$ ) Bill moderate, rather strong, slightly curved; widening towards the base, which is mucli broadcr than it is high. Base of the under mandible thickened, and not partially covered by the upper. Wings, feet, and tail as in Cinnyris.

A. Javanica. Zool. Ill. i. pl. 121.

Nectarin1a, Illiger. (fig. 288.e) Bill in general shorter than the head, wide at the base, compressed from the 
nostrils. ' $\Gamma$ ip of the upper mandible with a distinct notch; the margins entire. Wings long; the three first quills nearly equal. Lateral toes unequal. South Amcrica only.

N. cyanocephala. Zool. Ill. i. pl. 117.

Dicrum, Cuvier. (fig. 288. h) Bill short, remarkably broad at the base, and suddenly compressed beyond; the tips entire; the margins minutely denticulated. Nostrils triangular. Wings, fect, and tail as in $\mathrm{Nec}$ tarinea. Indian and Australian Islands.

D. sanguinea. Lewin, N. II. Birds, pl.7.

\section{. FAMtry 'TROCHILIDA.* Humming Birds.}

Wings excessively long, falcated. Feet very small.

LAMPonnis, Sw. Bill straight, or very slightly bent; generally pale; considerably depressed for its whole length, but more especially at the base. Wings reaching to the end of the tail, which is short and even.

L. mango. Brazil Birds, i. pl. 27, 28.

Trochros, Auctorum. Bill very straight, long, cylindrical, or rather broader than high. Tail generally even, but sometimes slightly forked.

T. longirostris. Auct.

Crnantuus, Sw. Bill cylindrical, more or less curved. Tail forked.

\section{C. forficatus. Auct.}

Phamernis, Sw. Bill considcrably compressed, generally curved from the base. Tail graduated, or cuneated. Colours lcss brilliant. The rasorial type.

P. superciliosus, Auct.

Campylopterus. Sw. Bill curved. Shafts of the quills dilated. Tail graduated. $\uparrow$

C. recurvirostris. Zool. Ill. i. pl. 105.

- The typisal aharaters alone are given of what I consider to be the primary groups ; but as the circular accession of the sulggenera in cach is a sulject which requires more investigation than I have yet been able to give it, 1 shall not attempt to impose names upon the minor groups, which cannot as yet be properly demonstrated.

+ The rank of this group is very uncertain. I am inclined to think that the "rrochilus recurzirostris is the type of the grallatorial division of this ifamily; but this is mere conjecture. 
SubaM. PROMEROPIDA. Hoopoes.

Feet syndactyle. The outcr toe united for half its length to the middle. Bill very long, greatly compressed.

Promerops, Brisson. Bill with the under mandible, at its base, thicker than the upper; the margins acute. Nostrils comeous; the aperture lateral and oval. Hind claw curved. Tail long, cuneated.

P. erythrorynchus. Ois. dorés, pl. 6.

UpupA, Lin. Bill lengthencd, greatly compressed Nostrils round, destitute of any membrane either above or behind. Hind claw nearly straight. 'Tail short, even.

\section{U. epops. Selby, pl. 40.}

Epimachus, Cuv. Bill resembling that of Promerops; but the margins are ohtuse, and somewhat inflexed. Wings, tongue, and feet unknown. Tail very long. Side feathers of the body greatly developed.

E. superbus. Ois. dorés, p. 18.

Sunfam, PARADISIADE. Paradise Birds.

Bill generally notched. Size large. Hypochondrial feathers greatly devcloped.

Prilonis, Sw. 13 ill greatly curved. Nostrils basal, plumed; the aperture linear. Wings rounded. Tail short, even. Tarsi short. 'Toes as in Meliphaga: hallux very strong, equal to the tarsus, and to the middlc toe. Soles flat and broad.

P. paradiseus. Zool. Ill. i. 481. Ill. of Orn. pl. 43, 44.

Paradisia, Sw. Bill strong, conic. Culmen convex, the sides compressed, the tip notched. Nostrils apparent. Feet strong, syndactyle, resembling those of Promerops. Tarsus short. Outer and middle toe ncarly of the same length; inner toe very short, but longer than the hallux, which is also shorter than the tarsus. Claws very strong, and hooked.

P. rubra. Vieil. Gal. pl. 99.

Cicinnurus, Vieill. Bill less robust; the tip notched. 
Nostrils entirely concealed by incumbent feathers. Hypochondrial feathers broad, compact, with truncated ends. Feet ㄴ.?

C. regius. Vicil, Gal. pl. 96 .

Parotia, Vieil. Bill slender, covered by soft feathers, directed upwards, for near two thirds its length. Nostrils concealed. Fcet and wings unknown.

P. sexsetacea, Vieil. Gal. pl. 97.

Lophorina, Vieil. Interscapulars excessively developed. A very doubtful type.

L. superba. Vieil. Gal. pl. 98.

Tribe V. FISSIROSTRES. Fissirostral Birds.

Feet of different constructions, but always short, and generally very weak and imperfect. Gape of the mouth very wide. Feed upon insects, caught during flight.

\section{Famut MEROPIDA. Bee-eaters.}

Wings loig, pointed; the first quill as long, or nearly so, as ally of the others. (fig. 289.)

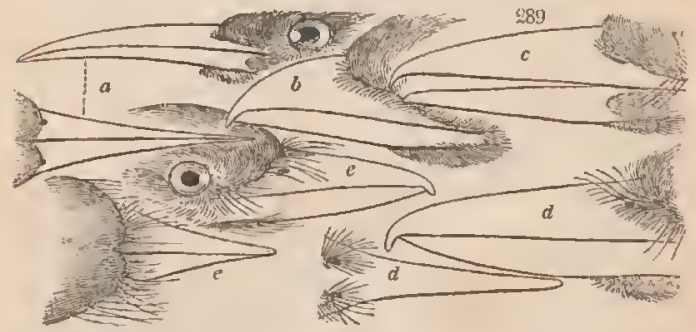

Merops, Lin. (fig.289.a) Bee-eater. Bill very long, slender, slightly curved, compressed : the culmen carinated; the tip entire, sharp, and not bent downward. Wings long, poiuted; the tips of the lesser quills emarginate. Tail lengthened. Feet gressorial. 
M. apiaster. Selby, pl. 41. Javanica. Horsf. urica. Zool. 11. i. pl. 8. Savignii. West. Af. ii.

Nycriornis, Sw. Bill considerably curved, very long: the culmen with a parallel groove on each side. Wings rounded, convex. Plumage lax. Feet short, insessorial, resembling those of Prionites.

N. amictus. Zool. Ill. ii.pl.56. cxruleus, Ill. Orn. ii. pl. 58.

(oractas, Lirn. Roller. (fig. 289. c) Bill moderate, straight; the sides broad, but much compressed. The tip of the upper mandible bent over that of the lower, which is obliquely truncate. Nostrils basal, oblique, linear. Gape very wide, extending beneath the eye; the sides bristled. Feet insessorial, very short. All the toes cleft to their base; inner toc much the shortest. Wings moderate, pointed.

$$
\text { C. Abyssinica. P1. Enl. 626. }
$$

Eurystomus, Vieil. (fig. 289. 6) Resembling Coracias; but the bill is shorter and wider, and the wings longer. Nostrils very long. Rictus smooth.

E. Orientalis. Part 5. No. 137. Australis, Part 5, No. 136.

Cinloropyur , Sw. General form between Tamatia and Coracias. Bill short; the tip not abruptly bent. Rictus bristled. Nostrils basal, linear, oblique. Wings short, convex, reaching only to the rump. The two first quills much graduated; the four next nearly equal, and longest. Tail clongated, rounded, and broal. Feet as in Coracils. Madagascar.

C. leptosomus. Lesson, III. Zool. pl. 22.

Leptosonus, Vieillot. Bill about the length of the head, robust. The upper mandible curved, and notehed near the tip. Gonys straight. Nostrils oblong, oblique; the margins clevated, naked, and placed towards the middle of the upper mandible. Feet short. 'Toes in pairs, as in T'amatia. Wings lengthened, pointed; the first and second quills longest. Tail moderate, even. Madagascar, 1.

L. viridis. Vieil. Gal. 40. Pl. Enl. 587. 
Family HALCYONIDAs. Kingfishers.

Wings rounded, not formed for rapid flight. Feet very feeble. Toes ju pairs.

TаматтA. Bill straight, compressed. Nostrils defended by long, stiff, incurved feathers and bristles. Rictus strongly bristled. Toes versatile, as in Cuculus.

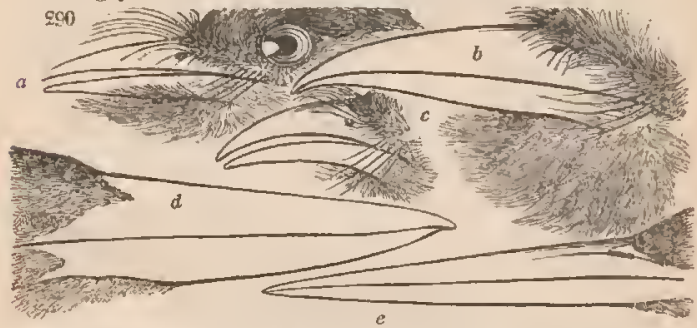

Tamatia, Cuv. (fig.289.e) Bill moderate, thick, conic; the tip but slightly bent. Tail narrow. Conirostral. T. maculata. Braz. B. pl. 11. bitorquata. Part 5. No. 138. Capito, Vieil. ( fig. 289. d) Bill long; the tip abruptly bent, so as to form a hook. Tail narrow. Dentirostral. C. leucotis. Braz. Bds. pl. 12 . somnolentus. Ib. pl. 9.

Lypornix, Wagler. (fig.290.a) Bill moderate, defended by very long bristles. Both mandibles nearly equal. Wings very short, rounded. Tail narrow. Tenuirostral. L. striata. Braz. Bds. pl. 34 . rubicula. Ib. pl. 35.

Monassa, Vieill. (fig.290.b) Bill as in Iypornix, without the basal bristles, but with short setaceous feathers. Wings short. 'T'ail lengthened, and very broad. Scansorial.

M. leucops. Brazil. Birds, pl. 12.

Brachypetes, Sw. (fig.290.c) Bill as in Lypornix, butshorter, higher, and more curved; the margins greatly inflexed. Wings long. Tail short and even. Fissirostral. (fig. 291.)

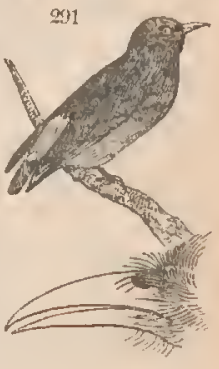

B. tenebrosa. Braz. Birds, pl. $\$ 5$. 
Hatcyos, Sw. Bill long, very straight, cylindrical ; the sides widened; the base more or less depressed. Gonys ascending. Feet syndactyle.

Dacelo, Leach. Margin of the upper mandible considerably sinuated near the tip. Wings lengthened; the quills slightly mucronate. 'Tarsus covered with rough scales. Australian range.

D. gigantea. White's Voy. pl. 2.

Halcyon, Sw. (fig. 290.d) Bill long, straight, broad, nearly quadrangulär. Culmen slightlyinclining towards the tip, ncar which the margin is slightly sinuated. Gape smooth. Wings broad, short, rounded. Tail very short. Fect syndactyle. Scalcs of the tarsus obsolete.

II. cinnamomina. Z.Ill.i.67.

diops. Pl. Col. 272.

melanoryncha. Ib. 391.

omnicolor. 1b. 135.

Smyrnensis. P. E. 894.

ruficollis. Sw. Ib. 232.

concreta. Ib. $346 . "$ lilacina. Sonn. Voy. pl. 218.

atricapilla. Pl. Enl. 673.

capensis. Ib. 590 .

collaris. Z. Ill. i. pl. 27.

sanctius. Lin. Tr. xv. 206.

leucocephala. P. Enl. 757. chlorocephala. Ib. 783. f. 2.

Syma, Lessol1. Differs from Halcyon in having the margins of both mandibles, for two thirds of their length, armed with numerous slarp and strong teeth. $\dagger$

S. Lessonia. Sw. (S. torotoro. Voy. Caq. 31. bis. 2.)

Todiramphus, Lesson. Habit of Halcyon. Bill broad, and greatly depressed its whole length ; the tips rounded, obtusc, and not inflexed. Gonys ascending, but without a ridge. Culmen obsolete. Commissure perfectly straight. Nostrils, wings, tail, and feet as in Halcyon; but the scales are distinct. South Seas.

T. sacer. Less. Mém. Soc. d'Hist. Nat. iii. pl. 11.

Ceyx, Lacepede. Bill and general strueture of Dacelo; but the inner fore toe is wanting.

$$
\text { C. tridactyla. Somu. Voy. pl. } 32 .
$$

A Lceno, Linn. Bill very straight, compressed its whole length: the tip of both mandibles acute, and the * Add to these the species deseribed in West. Af. Birds, vol, ii. + This type 1 have never seen, and am, therefore, unable to add its other eharacters, or to determine whether it enters into this circle or the next. † This type I have never seen. 
upper one not inclined. Commissure perfectly straight. Feet syndactyle, all the tarsal scales obsolete. Aleedo. (fig. 290.c) Tail very short. Feet with three toes before, and one behind. (laws simple. Culmen of the bill sharp, carinated, and simple. Inner and hinder toes of equal length. Inhabits only the Old World.

A. ispida. Selby, pl. 40. f. 1. Asiatica. Z. Ill. i. pl. 50. semitorquata. Z.11.i.151.

Ispida, Sw. Habit of Alcedo. Culmen obtuse, somewhat flattened, and margined on each side by an indented groove. Tail lengthened, rounded. Inner toe much longer than the hinder. Claws either deeply notched, or cleft so as to present two acute unequal points, Chiefly the New World.

I. alcyon. Edw. pl. 11.5. gigantea. West. Af. ii.

bitorquata. West. Af. ii. torquata. P1. Enl. „284.

Tanysipter $a$, Vigors. Bill depressed. Tail cuneated : the two middle tail feathers much elongated, with their tips spatulate. India.

T. Dea. Vig. Pl. Enl. 116.

Alcyone", Sw. Bill as in Alcedo; but the feet with only three toes. Australia.

A. Australis. Zool. Il], i. pl. 26.

LAmprotrla, Sw. l'lumage metallic green and gold. Bill very broad, dilated : the conmissure and culmen curved; the upper margins folding over the lower. Nostrils membranaceous; the aperture round, protected by fcatlers. Wings as in Galbula, but longer ; the third and fifth quills equal.

L. platyryncha. Vicil. II is. Nat. Jacamars. pl. 6 .

Galbura, Linn.† Plumage metallic. Bill very long, perfectly straight, greatly compressed: the culmen sharp; the tip not bent. Wings short. T'ail lengthened, graduated. Toes in pairs, or with the hallux wanting. Nostrils with a few strong bristles.

- As this is the only group in omithology wherein mythological names have been tolerated, I have ventured to entinue the netaphorical connection in this instance.

+ I comsider the threetoed speenes are the most typical, and that the whery are aberrmut, leasling to Limprotala. 

$\begin{array}{ll}\text { G. armata. Part 5. No. } 144 . & \text { viridicauda. Part 5. No.140. } \\ \text { lugubris. Ib. No. } 145 . & \text { lcptura. Ib. No. 141. }\end{array}$ paradisca. Edw, pl. 10. albiventer. Ib. No. 142. ruficauda. Part5. No.139. flavirostra. Ib. No. 143.

Family TROGONID A. The Trogons.

Bill short, triangular, strong; the tips, and generally the margins, toothed. Wings very short. Rasorial. Trogon, Linn. Both mandibles with their cutting margins serrated. The two anterior toes united as far as the first joint. Nostrils concealed by bristles. Tarsus entirely feathered. Tropical America. The dentirostral type.

melanurus. Part 5. No. 146. auratus. Ib. No. 147. purpuratus. Jb. No. 148. chrysogaster. Ib. No. 149. leucurus. Ib. No. 150. Mexicanus.Z. I.ii.pl.81.107. lepturus. Part 5. No. 151. meridionalis. Ib. No. 152. melanopterus. Ib. No. 153 . elegans. Gould, Mon. ambiguus. Ib.

melanoceplaala. Ib.

Harpactes, Sw. Bill stronger: both mandibles deeply notched at their tips, but the margins smooth. Nostrils partially naked. Tarsus only half feathered. The anterior toes less united. Tropical Asia. The conirostral type.

Malabaricus. Gould, Mon. erythrocephalus. Ib. Gouldii. (Sw.) P. C.121.

Temminckii. P. Col. 321.

Duraucellii. Ib. 291.

Diardii. Ib. 54.

Apaloderma, Sw. Bill as in Trogon, but the dentations almost obsolete. Feet stronger. The two anterior toes cleft to their base. Africa. The tenuirostral type.

A. Narina. Ois. d'Af. 228. Reinwardii. PI. Col. 124.* Temnurus, Sw. Bill as in Trogon. 'Tail feathers forked at their tips; the points diverging. South America. Feet-? the fissirostral type.

T. albicollis. Pl. Col. 326.

Calurus, Sw. Bill destitute of serratures. Head (typically) with a compressed and elevated crest. Upper pically) with a compressed and
feet; 1 am, therefore, doubtful if this is its true situation.

YoI. 11 . 
tail covers enormously developed, and hiding the tail. South America. The rasorial type.

C. resplendens. Gould, Mon. pavoninus. Spix, i. pl. 35 .

Crxpticus, Sw.* General structure of Prionites; but the bill excessively broad, flattcned, and dilated at the base. Culmen arched, grooved in the middle; the cutting margins minutely and regularly serrated.

C. platyrynchus. III. of Orn. iii. pl. 106.

Prionires, Illiger. Both mandibles slightly curved and compressed; the margins with strong denticulations. Tongue long, slender; the sides ciliated. Wings short, rounded. Tail lengthened, cuneated. Feet gressorial, as in Merops.

P. Braziliensis. Il. Pl. E. 370.

Bahamensis. Part 5. No. 154.

ruficapillus. Illiger.
Mexicanus. Zool. III. ii.

Martii. Spix, i. pl. 50.

Dombeyii. Le Vaill. pl. 39.

\section{FAmIY CAPRIMULGIDA. Nightjars.}

l'lumage lax, soft. Bill exceelingly small : gape enormous. Feet very short, weak: the hallux directed forwards. $t$

Ponargus, Cuv. Size large. The middle claw not serrated. The hallux not directerl forward.

Podargus proper. Bill large, very strong: the tip and margins of the upper mandible folding over those of the lower. Culmen elevated and arched. True rictal bristles none. Tongue very thin, entire. Tarsus short. Australia.

P. humeralis. Lin. Tr. xv, 198.

Egotheles, Horsf. Vig. Bill weaker, depressed. Tarsus lengthened. Middle and outer toes nearly equal ; inner much shorter. Australia.

IE. $\Lambda$ ustralis. Sw. White's Voy. pl. 29.

* It is by this form, as I suspect, uniting to Lamprolila, that the circies of the Holcyonide and the Trogonide are comnected.

t Until this family, and the next, are hetter understond, both in regard to the species, and the subordinate forms, I have thuught it best not to attempt their natural arrangement. 
Nyctibius, Humboldt. Bill small, as in Caprimulgus : the upper mandible with a projecting tooth. Feet broad, flat.

\section{N. grandis. Vieil.}

Caprnulgus, Lin. Bill remarkably small and weak; the sides inflexed, and sometimes gaping. Tarsus short. All the toes directed forwards; the inner and outer toes equal: the millde claw pectinated.

Caprimulgus. Gape strongly bristled. Tail lengthened, rounded. Lateral toes equal.

\section{Europaxus. Selby. i. pl, 42*.}

Psalurus, Sw. Gape strongly bristled. 'Tail excessively long, and very decply forked. Brazil. P. macropterus. Pl. Col. 157. bifurcatus. Sw. Sp. Nov. Chordeiles, Sw. Gape perfectly sinooth. Wings very long, equal to the tail, which is slightly forked. North America.

C. Americanus. N. Zool. ii. Wilson, 40. f. 1, 2.

Scortornis, Sw. General structure of Caprimulgus; but the outer lateral toe is shorter than the inner.

Scortornis. Rictus strongly bristled. Tail lengthened, graduated, or rounded.

S. climacterus. West. Af, ii. Vieil. Gal. 122.

Macrodipteryx, Sw. Rictus strongly bristled. Wings long, equal to the tail, and with a lengthened remiform feather in each. Tail even. Africa.

M. Africanus. Sw. West. Af. ii. Shaw, N. Miss. pl. 265.

Proithera, Sw. Rictus almost smooth. Wings very long, equal to the tail, which is short and even. Tarsus very naked. America.

P. diurnis. Pl. Col. 182.

FAMiLY HIRUNDINIDE. Swallows.

Plumage compact, glossy. Bill very sinall and triangular.

Crpseisus, Aristotle. Margins of the bill inflected and slightly gaping. Gonys ascending. Wings excessively long, curved. Feet sinall, weak. 'Tarsus very shori. 

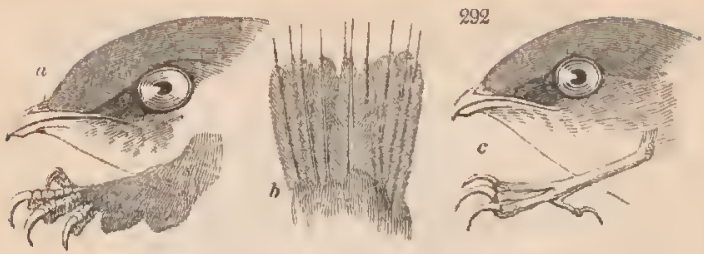

Cypselus. (fig. 292. a) Tarsus thickly feathered. All the four toes directed forwards; the two middle equal. The hallux, or inner toe, shorter than the exterior. Tail forked or even.

$$
\text { C. apus. Selby, pl. 42. f. } 4 .
$$

Macropteryx, Sw. (fig. 292.c) Tarsus remarkably short, naked. Anterior tocs long; the outer scarcely shorter than the middle; the inner shortest ; hinder toe very short. Tail long, forked. India.

M. Iongipenuis. Zool. Ill, ii. mystaceus. Less. V. C.pl, 42. pl. 47 .

comatus. Pl. Col. 268 .

Chetura, Stevens. ( $f$ ig.292.b) lieet as in the last, but the tarsus longer than the iniddle toe. Tail short, cren; the shafts prolonged into acute points.

C. macroptera. Zool. III. ii. pl. 42 . Hurunno, Limn. Bill flattened its wholc length ; the margins not inflected. Rictus sinooth. Feet insessorial. Lateral toes equal; middle toe longer than the tarsus. (fig. 293.)

H. rustica. Selby, pl. 42. f. 1.

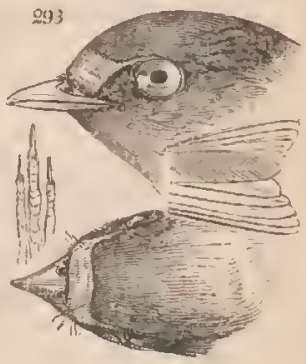

\section{Order RASOrES. Rasorial Birds.}

Fanily PAVONIDAs. Peacocks and Pheasants. Tail very much developed. Tarsus of the males gene rally armed with spurs. Hinder toe elevated. 
Pavo, Linn. Upper tail covers excessively developed : tail capable of being spread like a fan. Head plumed and crested. Tarsus spined.

P. cristatus. Pl. Enl. 433. muticus. Vieil. Gal. 202. Argus, Tem. Tail horizontally compressed; the two middle feathers excessively long. Wings with the secondary covers much longer than the primaries. Head and neck bare.

A. giganteus. 'Tem. Vieil. Gal. 204.

Polyplectron, Tein. (fig. 294.) Tail long, flat, rounded. Tarsus long, slender; armed in the male with several spines. Claws small; that of the hallux very short.

P. bicalcaratus. やl. Enl. 492 .
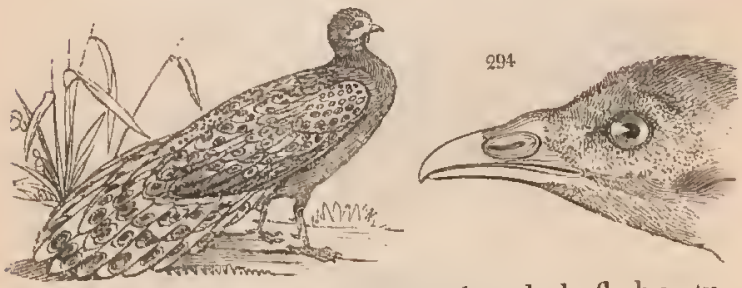

Melengris, Linn. Head and neck naked, fleshy, tuberculated; a fleshy caruncle in front. Tail round, capable of expansion.

M. gallopavo. Pl. Eul. 97.

Prasianus, Linn. Tail narrow, slender, graduaterl. Bill short, strong.

Phasianus. (fig. 295.) Hear and neck feathered. Orbits naked, warted.

occllata. Pl. Col, 112.

P. colchicus. Auct. The common pheasant.

Nycthemerus, Sw. Head furnished with naked wattles.

N. pictus. Pl. Enl. 217. N. argentatus. PI. Enl. 123. Cerionnis, Sw. Head partly naked; with fleshy hornz 3 
like caruncles over the eyes. Crown with a pendant crest.* (fig. 296 . a)

C. macroloplous. Less. Dict. des S. N. pl. 29.
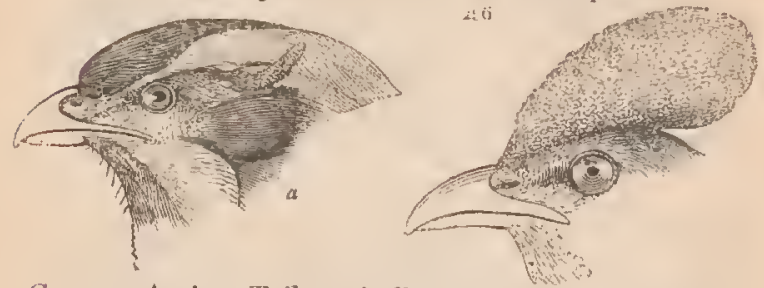

Galus, Antiq. Tail vertically compressed and carried erect; the middle feathers long, and arched. Bill moderate, strong. Crown with a fleshy naked crest. The mouth furnished with wattles. (fig. 296. b)

Lopnopuonus, Tem. Bill rather lengthened: the upper mandible very much curved, and projecting beyond the lower. Head featherel. Crown with a lanceolate crest. Tail even, straight. ( fig. 297.)

L. refulgens. Pl. Col. 507. leucomelanus, Pl. Col.pl. ].

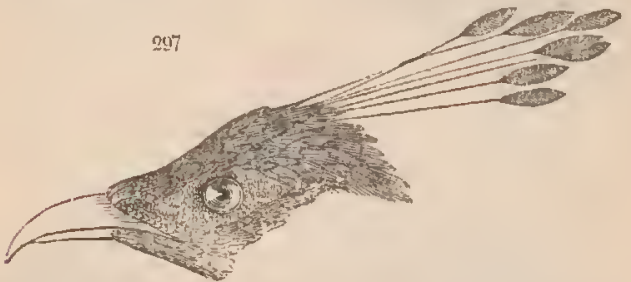

Numina Guinea-fowl. Bill short, strong. Nostrils lateral, placed in the cere. Head naked, surmounted by a callous crest. 'Tail short, bent downwards. Africa. ( $f i g .298$. )

N. meleagris. PI. EnI. 108. mitrata. Pall. Spi. 3. f. 1. cristata. Vieil. Gal, 209. maculipenuis. $W$. Af. ii. ptyloryncha. Mus. Paris.

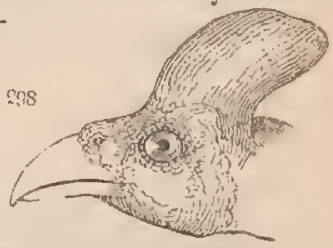

* M. Lesson's expressive name of Salyrus seems to have the priority, but it has long been used in Eintomology; and that of Tragopan is in every way objectionable. 
FAmL TETRAONIDA. Partridges and Grouse. Bill and tail very short. II allux elevated.

Cryptonyx, 'Tem. Bill short, thiek; the mandibles of equal length. Nostrils placed in the middle of the bill, and covered by a long naked membrane. Feet large. The hinder toe elevated, and without" a elaw. . Head conspicuously crested.

C. coronatus. Mus. Carl, pl, 64 .

Odontopronus, Vieil. Bill naked at the base, eonvex above, much eompressed, and with a double tooth near the point. Orbits and lores naked.*

\section{Tocro of 13 uffon.}

Orтуяs, 11l. Bill moderate, slcnder, straight. Nostrils lateral, linear, placed near the middle of the bill. Feet three-toed, slender. Hind toe wanting. Wings and tail very short; the latter nearly eoncealed.

O. nivosus. Zool. 111. i. pl. 163.

Texna0. Grouse. Bill short, very thick. Tarsus feathered. Four-toed. Eyebrows naked. Tail moderate, of twelve feathers. Wings short.

Tetrao, Linn. The tarsus feathered, but the toes naked. Sides of the neek, in the male, often with clongated feathers. Tail even. Eyebrows plumed.

T. Scoticus. Selby, pl. 59. f. 1. urogallus. P. Enl. 73.

Lagopus, Willughby. Bill with the base thiekly feathered. Eycbrows naked and sinooth. Tarsus and toes thickly eovered with feathers.

L. mutus. Selby, pl. 59. f. 2 .

Iyrurus, Sw. Toes naked. Tail lyre-shaped.

I. tetrix. Selby, pl. 58 .

Pterocles, Tem. Sand Grousc. Toes naked. Bill slender; the base thickly eovered with featliers. 'The hind toe very slort, or entirely wanting. Wings long, pointed. Tail graduated or cuneated. P. arenarius. P1. Col. 52. paradoxus. P1. Col. 95.†

* 1 have not been ahle to examine accuratcly these first two genera.

t I consider this bird as the real type of the whole group. 
Centrocircus, Sw. Tail feathers lanceolatc, ending in naked points.

C. urophasianus. N.Z. ii. pl.58. phasianellus. Edw.117.

Pernix, Briss. Nostrils and tarsi naked. Bill with the general structure of Tetran; short, strong, and very convex; the tip broad. Wings generally rounded. Tail very short.

Perdix. Partridge. Frontal feathers advancing in front between the nostrils. Tarsus smooth; posterior tarsal scales large, transverse, strong, in two rows, and nearly equal to the anterior scales. Inmer toe much shorter than the outer; hinder toe very small. Claws very broad, and nearly straight. Tail even, or very slightly rounderl. Universal.

\section{P. cinerea. Selby, pl. 61.}

Chatopus, Sw. Francolin. Frontal feathers divided in front by the base of the bill. Tarsus generally armed with spurs in the male: posterior tarsal scales, small, hexagonal, much smaller than those in front. Inner toe equal, or ncarly so, to the outer. Claws compressed. Tail very short, often nearly hidden by the covers. Chiefly Tropical $A$ sia and $A$ frica.

C. Adansonii. West. Af. ii. Vaillantii. Pl. Col. 477 .

Pondicerianus. PI.C.213.

Coturnix, Briss. Quatls. Stature small. W'ings with the first quill as long as the otliers. 'Tail very short, fasciculated, conecaled by the covers. Universal.

$$
\text { C. Europaus. Selby, pl. 62. }
$$

Ptilopachus, Sw. Bill small, slender. Nostrils naked, very large, occupying one half the length of the bill. Wings rounded. Tail broad, rounded, larger and longer than in Perdix; the feathers very soft. Feathers of the back and rump with the shafts thickened, and apparently spinous, as in Ceblepyris. Tarsus shorter than the middle toe. Lateral toes nearly equal. Africa and India.

$$
\text { P. erythrorynchus. West, Af. ii. }
$$


Ortyx, Stevens. Bill short, very high ; the culmen considerably elevated and curved: the tip hooked: the gonys thick and ascending. Nostrils large, naked. Varsus smooth. Lateral toes unequal ; hinder toe none. Tail moderate. America only.

o. Borealis. Wil. 47. f. 2. malurus. Spix, ii. pl. 76. a.

Crypturus, Ill. Tirnamm. Bill slchder, weak, lengthened, as long as the head. 'The base of the culmen broad and flattened. Nostrils vcry long; the aperture naked. Gonys excessively short. Feet smooth. Inner toc shortest. Tropical America.

Crypturus. Bill slightly depressed. 'The aperture of the nostrils large, oval, and placed in the middle of the bill. Tail feathers firm, but concealed and confounded with the upper covers. Hind toe minute, not longer than its claw.

C. lepidotus. Zool. 11l. i. pl. 19. serratus. Spix, pl. 76.

Nothurus, Wagler. Bill very wide at the base. Frontal feathers alvancing to the aperture of the nostrils. Tail feathers none; the upper covers soft and loose. Hinder toe longer than its claw.

N. rufescens. Spix, pl. 76. a. minor. Sp. pl. 82. P. C. $\$ 16$. PI. Col. 412. maculosus. Spix, pl. 80.

Family STRUTHIONID无. Ostrich.

Stature very large. Wings short. Often incapable of flight.

Otıs, Linn. Bustards. Bill short, straight; the base depressed ; the sides compressed and conic. Feet long, naked above the knee. 'Toes three, directed forwards, short, with a connecting membrane. Wings moderate; the third quill longest.

O. tarda. Pl. Enl. 24.5.

Strutulo. Ostriches. Wings abortive. Bill much depressed.

Struthio, Antiq. True Ostrich. Wings short. Head naked. Feet with only two unequal toes, placed in front. S. camelus. Pl. Enl. 457 . 
Casuarius, Ray. Cassowary. Bill strong, emarginate. Head and neck naked; the former with an elevated protuberance, the latter with wattles. Feet threetoed, all placed forwards.

C. galeatus. Pl. Enl. 313.

Dromiceus, Vieil. Emu. Head smooth, feathered. Bill short, depressed, resembling that of Platyrynchus. Under mandible serrated. Nostrils naked, linear, placed in the middle of the bill. Throat naked. Feet with three toes, placed forward. Tarsus strongly serrated behind. The rasorial type. Frugivorous and herbivorous.

D. Australis. White's Voy. pl. 1.

Apternyx, Shaw. Kiwi. Bill slender and considerably lengthened. Feet short, with three toes before, and a spur, representing the hallux, behind. The tenuirostral type.*

A. Australis. Zool. Trans. i. pl. 10.

Rhea, Brisson. Bill straight, depressed; the tip bent down and hooked. Head feathered. Feet with three toes before, and a callous protuberance behind. Wings developed, but too slort for flight. Insectivorous. The fissirostral type.

R. Americana. Auct.

Famity COLUMBIDA. Pigeons.

Feet very short. Wings long.

* There is scareely any bird out of the grallatorial order, which so beau. tifully represents it as this. BIr. Yarrell is even struck by the resemblance of the bili to "tline of an ibis." Although, perliaps, the resemblanee of this part, from its thickened termination, is much moresinular to Scolopns.

$\uparrow$ So far as I have yet proceeded in the analysis of this groum, I have formed the following npinions:-1. That the true pigeons eonstitute nuly one of the five primary rivisiolns; just as the true woodpeckers (Picinnit) form only one group lin the circle of Picinde, so that both are of equal rank and value. 2. It consequently follows that the four other divisions of the $C 0$. numbilce are either represented by birds which have not been yet diseovered, or by types very neculiar in their general appearance. 3 . Of this latter I consider that Opisthocomus couneets the Cotumbide with the Megalopide, by means of Dicrolophus, and that Clionis is the grallatorial representative, Of the two remaining types, one of which is the fissirostral, I am guite iknorant: I think it more than probable, however, that the true pigeous forn one circle, and not twa. 
Surfar. COLUMBIN As. True Pigeons. Bill lengthened, slender; the base soft and tumid. Wings long. Feet very short. Rump feathers thick, rigid, and apparently spinous, as in the Ceblepyrince.
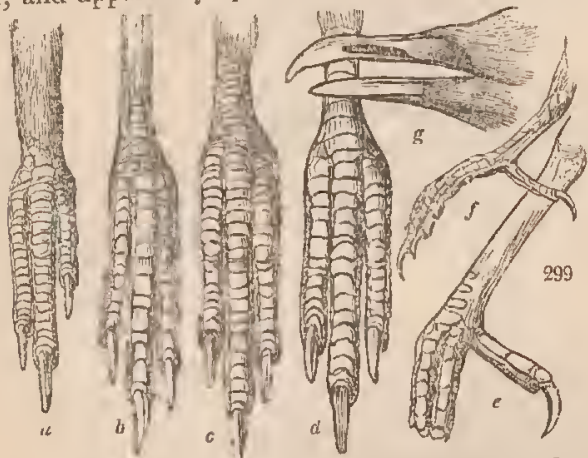

l'Tulonopus. (fig. 299. a. 300. $e, d$ ) Tarsus short, feathered. Toes cleft to the basc; the inner shortest. Bill short: the extremities of the two mandibles of equal thick ness. The gonys very short, strong, and forming an ascending angle. Tropics of Asia and $\Lambda$ ustralia.

Ptilonopus, Sw. Bill slender. IVings moderate; the first quill shorter than the second, and generally narrowerl ; primaries not inuch longer than the tertials. Tail moderate, rounded. purpuratus. Nat. Iib.v.pl.3. monachus. P1. Col. 253. lencogaster. Nat. I ib.v. pl.5.

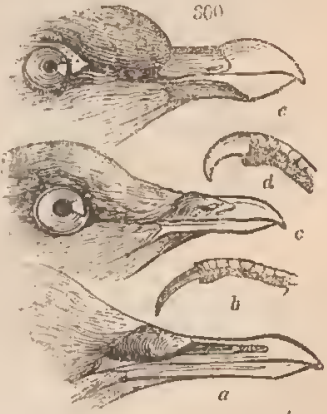

bypogaster, Pl. Col. 25 ?. flavigaster. Ib. 254. erytlirocephalus. 1b. 106 . maguificus. Pl. Col. 163.

Vinago, Cuv. (fig. 300.e) Bill very strong. Wings pointed; the three first quills nearly equal, and much longer than the others; tertials short. 
V. calva. Tem. Pig. i. 63. olax. Pl. Col. 241. aromatica. Pl. Enl. 163.

Sphenurus, Sw. Habit of Vinngo; but the tail long and graduated; the two middle feathers greatly narrowed, and projecting considerably beyond the rest. Fissirostral type.

S. semitorquatus. Pl. Enl. 240.

Lophorynchus, Sw. Bill strong: the base of the under mandible considerably thickened. Nostrils surmounted by a compressed and recurved crest advancing on the basal half of the culmen. Wings very long; the two first quills slightly graduated. Tail long, even. Australia. Rasorial type.*

L. dilophus. Shaw's Zool. X. H. pl. 5.

Columba, Linn. Bill slender. Feet formed both for perching and walking. The tarsus not longer than the hallux; the lateral toes equal. ( fig. 299. d)

Columba. Wings rather lengthened and pointed; the three first quills nearly equal, and longest. Tail rather short, even, or sliglitly rounded. Hinder toe longer than the tarsus.

C. palumbus. Selby, pl. 56. f. 1.

Geopelia, Sw. Size small. Wings short, rounded; the three first quills graduated, the first generally narrowed towards the tip. Tail lengthened, graduated, obtuse. Hinder toe shorter than the tarsus. India. The tenuirostral type.

G. Tineata. Mus. Carl. pl. 67.

Ectopistes, Sw. Wings very long, pointed; the two first quills the longest. Tail cuneated; the four middle feathers lanceolate. Hinder toe and tarsus equal ; the latter half-plumed. The fissirostral type. ( fig. 299. c,g)

E. migratoria. Wilson, pl. 44. f. 1.

Macropygia, Sw. Wings moderate, rounded; the first and second quills graduated, and much shorter than

* The Columbr oceanica and arner, which thave not examined, may possibly represent the remaining, or tenuirnstral type; in which case thev can bear Mr. Selby's cxcellent name of Carpophagr. Vide Nat. Lib. v. p. 117. 
the third. Tail long, graduated; the feathers very broad and obtuse. The rump feathers very thick set. Bill short: the gonys angulated. Tarsus plumed. Hinder toe longer than the tarsus.

M. phasianella. P1. Col. 100. infuscata. Lich. (Brazil.)

Reinwardii. Ib. 218.

'l'urtur, Selby. Turtles. Bill slender. Tarsus naked: the tarsus and hallux of equal length. The outer toe shorter than the inmer.

Turtur. Wings rather lengthened; the two first quills slightly gradnated. 'Tail moderate, even, or rounded. T. migratorius. Selhy, 56. f. 2. risorius. Pl. Enl. 244. Ena, Selby, MSS. (fig. 299. $f$ ) Wings lengthened; the first three quills nearly equal, and longer than the others. 'Tail long, cuneated; the two iniddle feathers narrowed. Feet very small. Represents Ectopistes. Africa.

O.Capensis. Selby, Ois. d'Af, 273.

Chamepelia, Sw. Wiugs short, rounded; the four first quills nearly equal, and not mueh longer than the tertials; the feathers very broad. Tail moderate, rounded. A line of feathers on the tarsus. America.

C. cinnamomina, Spix, ii. 75. a. f. 1 .

Leptotila, Sw. (fig. 299.b, c. 300.b) First quill suddenly narrowed; the fourth longest. Tarsus lengthened, and much longer than the hallux. All the toes long and slender. Knees naked. America only?

P. rufaxilla. Nat. Lib. v. pl. 24.

Perister A, Sw. ( $f y$. . 299. b, e. 300. a) Bill lengthened, slender. Wings pointed ; the second quill longest. Tail moderate. 'Tarsi rather short. Lateral toes equal; hinder toe very short, not more than half the length of the middle toe. Austratia only.*

P. calcoptera. Nat. Lils. v. pl. 21. scripta. Pl. Col. 187. Ptrlopuyrus, Sw. Crownbird.t Size large. Wings

* As the bronze-winged pigeons of New Holland appear to me the true aples of this genus, I have retained to them, as is usual in such cases, the subgeneric name; but not having finshed the analysis of this family, I do not venture to characterise the other subgenera: tlie snme vibservation is applicalle to the next genus.

+ See Vol. 1, p, 233. 
short. Tail long, rounded. Tarsus much lengthened. Head with an elevated compressed crest.

P. coronatus. Ois. d'Af. pl. 280.

Cinonis, Forster.* Bill short, strong, compressed, entire. Nostrils tubular, protected by hard, elevated, and complicated folds, which envelope the hase. Front of the head, and part of the face, naked. Wings very long. Feet very short, strong. Tarsal scales small, rough. Outer and inner toc slightly connected; the inner shortest, and cleft at the base: hinder toe short, not elevated, and placed

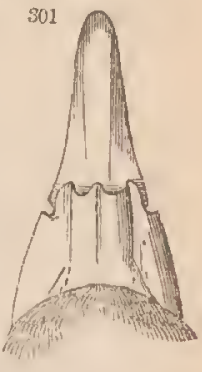
on one side, as in the genus Colius: middle toe lengthened. Claws moderate; much worn by walking.

C. vaginalis. P1. Col. 509 .

\section{Famix MEGAPODINZ.t Greatfoots.}

Size large. Feet remarkably developed, very large. The hinder toe lengthened, and on the same plane with the others.

Menura, Shaw. Bill moderate, depressed at the base, straiglit; the tip obsoletely notched. Nostrils naked, and placed near the middle of the bill. Feet very large, strong, and robust. Nearly all the anterior toes equal. The claws enormous for the size of

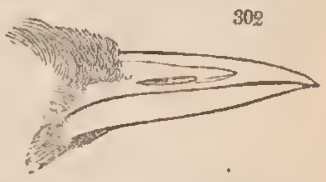
the bird, obtuse, and slightly curved. Wings short. Tail very long, lyre-shaped; the feathers singularly

* As some explanation of the station I have now assigned to this remarkable type, it must be remembereri, that as the Columbicte are the most aberrant of the rasorial order, so is Chronis the inost aberrant of the Columhida. The exprienced ornithologist will diacover many beatiful unalogies resuling from this arrangement. The above generic characters have been drawn up from a cureful exanination of a speciuen in the British Museum.

+ As I have every reason to believe, from an attentive study of this fanily, that Cras is an aberant genus, I have thought it better at once to correct my former error, and to name the whole from that group which is one of the chief types. 
developed. The typical or conirostral form of the whole family. Australia.

M. paradisea. Vieíl. Ois. dor, ii. pl. 15, 16.

Megapodius, Gaimard. Bill small, very short, compressed. Culmen arched, and curved fron the base: the base not wider than high. Nostrils as in Menura. Feet strong,

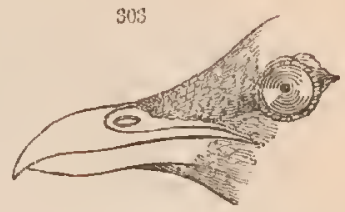
enormously large, resembling those of the last. Wings moderatc. Tail very short.

M. Freycinetii. Pi. Col. 220.

Pafamenis, Linn. Bill short, compressed; the base high, and the point considerably curved. Feet large, thick, naked just above the knee. The claws very long. The lateral tocs equal; the middle lengthened. Claws moderate ; the hinder one longer, and nearly straight. Wings moderate, very broad. The carpus armed with bony spines. Tail short. America. Subtypical. P. cornuta. Pl. Enl. $451 . \quad$ cristata. Pl. Col. 219.

Dicholoptius, Illiger. Bill longer than the head, thick, and strong; the base depressed; the tip compressed, and curved downwards. Nostrils very large, membranaceous; the aperture in the middle of the bill. Feet long, slender. The three anterior toes very short and thick. The hinder much raised, and not touching the ground. Claws short, strong. Wings moderate, much rounderl. (Temminel.) The rasorial type. South America.

\section{D. cristatus. Pl. Col. 237.}

Psopirs, Linn. Bill slort, compressed: the culmen curved from the base, and of the true rasorial structure. Nostrils large, naked, basal; the aperture oval. Feet long, slcnder. The outer and inner toc very slightly connected; the inner cleft. Wings short, concave. Tail very short. The grallatorial type. S. America.

P. crepitans. Pl. Enl. 169. 
Crax, Linn. Bill various. Wings short. Taillengthened. Feet rather large. The hind toe long, and placed on the same plane with the others. Claws curved.

Crax,Linn. (fig.304.) Bill moderate, compressed : the eulmen curved from its origin ; the base covered with a cere, in whieh are the naked nostrils, having their aper-

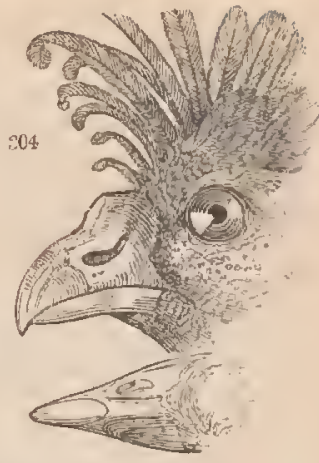
ture long, curved, and linear. Head crested.

C. globifera. I'L. Enl. 86.

Ourax, Cuvier. Front 305 plumer. Bill very short, asligh as it is long, greatly eompressed, without a cere. The nostrils transverse, nearly hid by the frontal feathers. (fig. 305.)

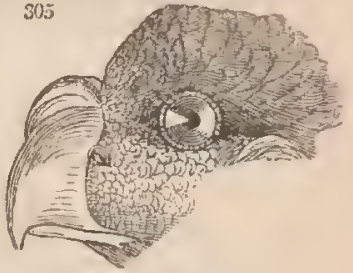

- O. erythrorynchus. P1. Col. 153.

Ortalida, Merrem. Bill short, high; the culmen much arehed. Cheeks nakel, warty. The throat with a naked stripe on eaeh side.

\section{O. garrulus. Pl. Enl. 146.}

Penelope, Limn. Bill small, slencler, mueh longer than high; the base straight, but the eulmen eurved beyoud. Nostrils very large, naked, half the length of

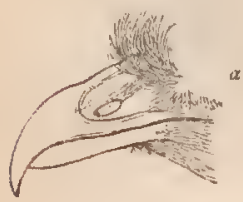

306

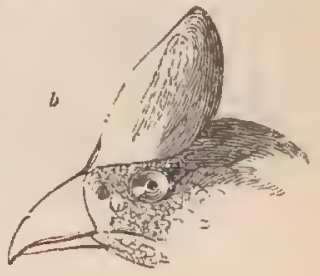


the bill. Face and sides of the chin naked. Lateral toes equal. ( $f i g .306 . a$ )

P. cristata. Edwards, pl. 13.

Lophocerus, Sw." Front of the head with an elevated, pear-shaped, horn-like protuberance. Bill intermediate in shape between Crax and Ourax. Cere small. Nostrils basal, oval or round. ( $f i g .306 . b$ )

C. galeata. Lath. Pl. Enl. 78 .

Order GRALLATORES. Waders.

FAMILX ARDEAD西. Herons and Cranes.

Size large. Bill long, conic, very hard, straight, and compressed. Hind toe moderate, and placed on the same level as the others.

ArDEA, Linn. Bill long, very straight throughout, conic, compressed from the base. Middle claw serrated.

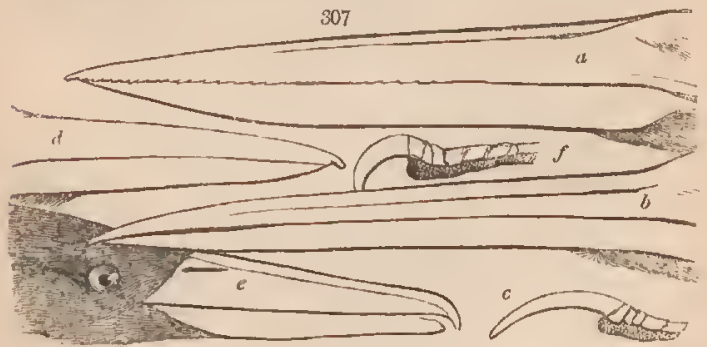

Ardea, Linn. Herons. (fig. 307. a) Bill very strong, perfectly straight; the tip not bent downwards; the margins serratel : the gonys strong, and ascending. Scapular feathers long and linear. Legs long. Thighs naked a considerable distance from the knee.

* By this form I cousiler the rircit of the Rasores is elosed; the genus Crax thus blending into that of Numila in the family of Pawonida.

VOL. II.

A $\mathrm{A}$ 
A. cinerea. Selby, ii. pl. 2. palliata. Spix, pl. 90. Herodias. Wil. 65. f. 2. pacifica. Ill. Orm. pl. 90. Egretta, Brisson. Egrets.* (fig. 307. b) Bill more slender : the culmen iuclining towards the tip, and bent downwards : the commissure slightly gaping towards the end; the margins serrated: the gonys short, slender, and not ascending. Scapular feathers (typically) very long, and divided into detached filaments, Legs long. Inner toe shorter than the outer.

E. Americana. Wil. 61.f.4. cerulea. Wil. 62. f. 3. alha. Nauman, 46. f. 91. nigerrima. Wagler, 22.? Ravirostris. Wagler, 9. Lurloviciana. Wilson, 64. f. 1. Garzetta. Auctorum.

* Aberrant, leading to Butor. candidissima. Wil.62. f. 4. scapularis. P1. En1, 908. Part russata. Pl. En]. 910. comata. Selby, ii. pl. 6. 5. No. 155 . Agami. Pl. Enl. 859. gularis. West. Af. ii. unicolor. Ib. ii. virescens. Part 5. No. 156. Javanica. 1b. No. 158. thalassina. Ib. No. 157. plumber. Ib. No. 159.

Butor, Antiq. Bitterns. Bill as in Ardea. Face naked. Legs almost or quite feathered to the knees. Inner toe cunsiderably longer than the outer. Claws long, slender, very slightly curved (fig. 307.c). An terior scales transverse. The grallatorial type.

B. stellaris Selby, ii. pl. 8 . exilis. Wilson, 6.5. f. 4. Americaua. Wil.pl.65.f.3. minutus. Selby,ii.pl.6. f̌. 1,2.

Tigrisonn, Sw. Tiger Bitterns. Bill as in Ardea. Face, and sometimes the chin, naked. Legs almost feathered to the knces. Inner toe rather shorter than the outer. Claws short, stout, regularly curved $(f y .307 . f)$. Anterior scales reticulate or hexagonal. The rasorial type.

'I. linenta. Pl. Col. 860.

Nyctinrdea, Sw.t Night Herons. Bill rather short, broad, stout. Culmen curved from the base; the tip bent, and deeply notched; cutting margins curved,

* I have consiricrably extended the limita of this subgenus, which the prince of Musiguano restricts to the white egrets only.

t Nycticorar, implying a resenblance altogether lalse, I have ventured to propose the true meaning of the vernacular name by which these birds are so well known. 
sharp, entire. Gonys long, and nearly straight. Feet as in Tigrisoma. Anterior scales partly hexagonal, and partly transverse. Inner toe shorter than the outer. The fissirostral type.

N. Europæa. Selby, ii. pl. 7. violacea. Wil. pl. 65. f. 1. leuconotus. Wagler, sp. ? pileata. P1. Enl. 907. 33. (fig. 307. d)

Caxcroma. Linn. Habit of Ardea. Bill short, excessively broad, and boat-shaped. The upper mandible folding over the cutting edges of the lower.

C. cochlearia. Pl. Enl. 38.

Puatalea, limn. Bill long, depressed, very flat, and spoon-shaped, the tip being consilerably dilated.

P. leucorodia. Selloy, ii. pl. 10.

Ciconia, Brisson. Bill much lengthened, perfectly straight, and somewhat conic: the culmen more or less dcpressed in the middle. Nostrils placed in a groove which extends to half the length of the bill. Ilead more or less nakcl. Feet four-toed. The middlc claw not serrated, or the hind toe elevated. N. B. The subgeneric types require investigation.

$$
\text { C. alba. Pl. Enl. } 366 .
$$

Mycteria, Limn. Size gigantic. Bill strong, long, conic : the culmen perfectly straight : the gonys recurved. M. Americana. Pl, Enl. 817. Australis. Lath. Syn. pl.138. НжMatopus, Linn. Bill long, very straight, contracted in the middle as in some of the Ciconia; the tip wedge-shajed. Feet three-toed. The grallatorial type.

H. ostralegus. Selby, ii. pl. 33. f. 1, 2.

Scopts, Brisson. Umber. (fig. S0T.e) Bill straight, broad, much compressed: the tip of the upper mandible abruptly hooked, and of the lower truncated. Culmen and gonys carinated. Nostrils lincar, clused. Wings long. 'Tail short. Legs moderate. All the toes united by a mcmbrane; the inner slortest.

S. umbretta. P1. Eul, 796 .

$$
\text { A } \mathbf{A} 2
$$




\section{Famex TANTALIDA. Ibis.}

Size large. Bill hard, considerably lengthened, cylindrical, and curved from the base. Face or head more or less naked. Hinder toe on the same plane as the others. Plunage metallic. 'The tenuirostral family. Axsstonus, Illiger. ( $f g .308$.) Openbeak. Bill straight, hard, heavy, solid, compressed, marked with longitudinal wrinkles. Upper mandible very straiglıt; the base thickence at the top,

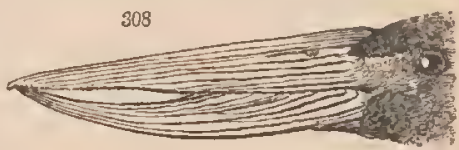
and as high as the crown; the tip notched; the margin dentated: under mandible greatly curved upwards, and only touching the upper at the base, and at the tip.

A. lamelligerus. PI. Col. 236.

TAxtalus, Lim. Bill nearly as thick, at the base, as the liead; cylindrical and attenuater towards the tips, which are slender and slightly bent: inargins entire. Upper mandible notched. Nostrils naked, vertical, basal, oval-oblong. 'Toes counected at the base.

T. loculator. Wilson, pl. 66. f. 1.

Iвıs, Antiq. Bill much more slender; cylindrical, and arched from the base. Nostrils basal, lateral. Wings broad, ample : the second and third quills longest.

I. ruber. Pl. Iinl. 80,81 .

Aramus, Vieil.* Bill lengthened, slightly curved towards the point, which is entire and inflexed. Under mandible curved from about the middle, and angulated. Furrow of the nostrils long. Nostrils lateral, remote from the base, longitudinal. Feet long. Hallux elevated. Anterior toes divided at their base. Wings moderate; the two first quills shorter than the third, which is the longest. America.

A. scolopacius. Pl. Enl. 848.

* This type I have not examined: the above characters are those of H. Temminck. It seems related, either by analogy or affinity, to the rails. 


\section{Famuly RALLID五. Rails.}

Feet very large. Bill in general short, and greatly compressed. Tail excessively short, nearly hidden by the covers. Hinder toe elevated.

Parra, Linn. Jamana, or Spur-wing. (fig. 309.) Bill straight, slender, moderate. Feet very long. Toes and claws of enormous length; the latter straight or re-

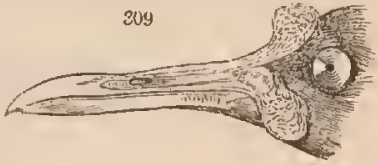
curved. Carpus generally armed with acute spurs. Typical.

P. Africana. Zool. Ill. ii. pl. 6.

Porpirmo, Briss. Sultana. Bill short, strong, high ; the base dilated into a flat plate on the front of the
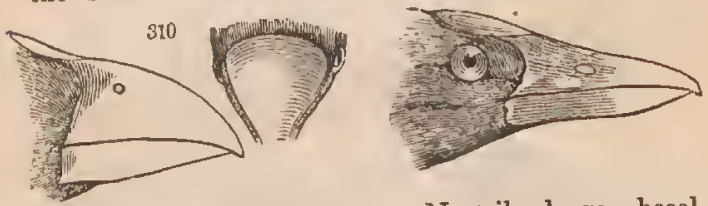

head; the culmen arched. Nostrils large, basal, covered by a membrane, naked; the aperture terminal, and oval. Feet very large. Toes without any lateral membrane. Claws large, slightly curved. Subtypical. ( fig. 310.)

P. smaragnotus. Tem. Man. Americanus.* Wil, 75. f. 2. ii. p. 700 . albus. White's Voy. pl, 27.

Fubica, Linn. Coot. (fig.311.) Bill as in Porphyrio, but more slender : the base straight: the gonys short and angulated. Feet very large. The toes margined with

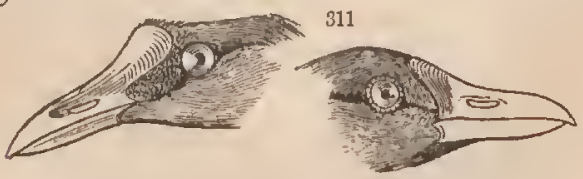

- The Gallinula Martinica of Iatham, but a true Porphyrio.

A $\mathbf{A} 3$ 
a lateral membrane, which is either narrow, and of equal brcadth, or dilated into lobes. The natatorial type.

* F. Chloropus. Selby, ii. pl. 31. atra. Selby, ii. pl. 39. Ratudus, Linn. Rail. Bill lengthened, slender. Both mandibles, in general, slightly curved, and with

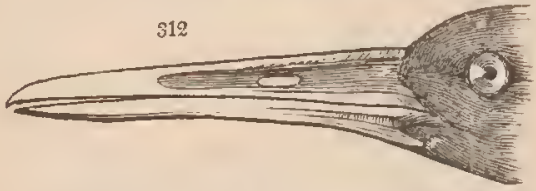

thcir margins considerably inflected beyond the nostrils. The tenuirostral type. (fig. 312.)

R. cæsius. Part 5. No. 162. neglectus. Part 5. No. 164. sanguinolentus. Ib. No. brachypus. Ib. No. 165.

161.

Lewinii. Ib. No. 166.

superciliosus. Ib. No.163. albiveuter. Ib. No. 167.

Galinula, Auct. Water-Hen. Bill short, straight; the margins not inflexed. The cutting edges of

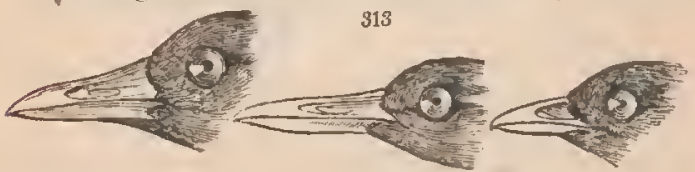

the upper mandible folding over the lower. Gonys very short, angulated. Toes simple, without any marginal membrane. The rasorial typc. (fig.313.) immaculata. Part 5. No.168. ecaudata. Part 5. No. 200. curvirostrit. Il). No. 169. flavirostra. Ib. No. 170. modesta. Ib. No. 201 . leucosoma. Ib. No. 202. albifrons. Ilb. Nc. 171.

Alecthelia, Lesson. 'Tail feathers obsolete, or confounded with those of the rump, some of which are laterally compressed, and all are long, lax, and very soft. $t$

A. lineata, Part 5. No, 172.

* I consider this as only an aberrant species, with the lobes not so muen developed, just as we see among the phalcropes : it may be placed, indeed, with Porphyrio, but has no connection whatever with Gallinula.

+ This extraordinary form is, in all probability, the true type of Galli. nula. 
Family SCOLOPACIDA. Sundpipers and Snipes.

Wings long, much pointed. Tail very short. Bill very long, slender, soft, cylindrical: the culmen straight its whole length. Hinder toe generally present, elevated above the others.

Evrypvara, Illiger. Bill resembling Gallinula, but larger: the nasal groove very deep, and long. Wings long, rounded. Tail large, broad.

E. Helias. P1. Eri. 782.

Scolopax, Linn. Bill straight, very. slender, narrow, soft, but depressed and dilated close to the tip: the margius not inflexed: the nasal groove reaching to the tip.

Rynchaa, Cuv. Bill much lengthened: the upper

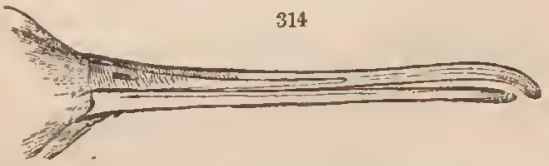

mandible thickened and curved at the tip. Tarsus not longer than the middle toe. Rasorial. (fig. 314.)

R. Capensis. Pl. Enl. 270.

Scolopax, Linn. Bill very much lengthened, straight, and the tips rough, with excavated spots: the tip of

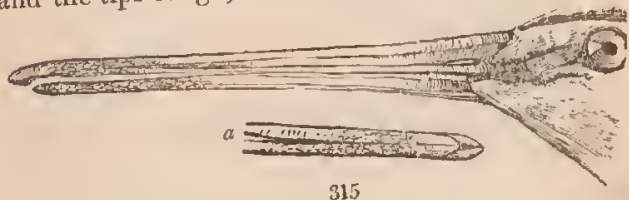

upper mandible thickened and projecting beyond that of the lower, which it receives in a groove. ( $f g .315 . a$ ) Middle toe much longer than the tarsus. ( $f g .315$. S. major. Selby, pl. 23. f. 2. rusticola. Selby, 23. f. 1. griseus. Ib. pl. 24. f. 2.

Limosa, Brisson. Bill very long, either straight, or 
inclining a little upwards; flattened towards the tip, which is mere or less dilated, always smooth, and that of the upper mandible never thickened beneath.

Tarsus longer than the middle toe. Anterior toes semipalmate, flattened, with a marginal membrane on each side; hinder very small. (fig. 316. 317.a)

L. melanura. Selby, ii. pl. 21. fedoa. Wilson, pl.56. f. 4. Phalaropus, Brisson. Bill remarkably slender and flexible; the nasal grnove extending only half way Tarsus short, not longer than the hind toe. Anterior toes semipalmated, and margined either by a narrow and simple, or a lobed and more dilated, membrane. The natatorial type.

Hyperborea. Selby, pl. 28. f. 1, 2. Wilsoni. N. Z. ii. pl. 69. Tringa, Linu. Bill moderate, generally straight, soft and flexible; the tip dilated and smooth. Tarsus longer than the inidale toe. Anterior toes generally cleft to their base, flattened, and with a marginal membrane; hinder toe very small, sometimes wanting. The grallatorial type. (fig.317.) C. arenaria. Bon. Syn. 320 . canutus. Selby, ii. pl. 27. f.1.3. Humantopus, Brisson. Bill straight, very slender, narrow; hard, the outcr half not depressed, but rounded, the margins being inflexed. Nasal groove extending only to half the length of the bill. 
Recurvirostra, Linn. Bill flattened; flexible, the tip narrow, very thin, and curving upwards. Legs very long. Anterior toes conspicuously semipalmated. The natatorial type.

\section{R. avosetta. Selhy, ii. pl. 20.}

Himantopus, Brisson. Bill very narrow and slender; the base depressed, but the outer lalf cylindrical and slightly inclining upwards. Tarsus excessively long. Anterior toes semipalmated; the inner shortest; the hinder toe wanting.

H. melanopterus. Pl. Enl. 878.

Totanus, (fig.

318.) Bech-

stein. Bill

rather strong,

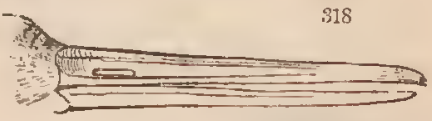

either straight or inclining upwards ; the sides, at the base, much compressed, but eylindrical beyond. Anterior toes slightly semipalmate; the lateral toes equal; hinder toe slender, rather longer than usual.

T. fuscus. Selby, pl. 15. f. 1, 2. semilalmatus. N. Z. pl. 67.

Machetes, Cuvier. Bill straight. Feathers of the neck, in the males, much developed. Anterior toes considerably semipalmated. The rasorial type?

\section{M. pugnax. Selby, pl. 25.}

Falcinellus, Cuvier.* Bill more or less arched. The hinder toc wanting. (Tem. Man.)

Strepsilas, Illiger. Turnstone. Bill short, very straight, conic, compressed its whole length: the gonys bent upwards: the nasal groove hardly extending be-

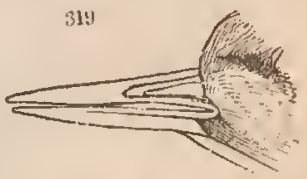
yond the aperture of the nostrils. Tarsus not longer than the middle toe. Anterior toes cleft to their base, and margined; hinder toe moderate. The natatorial type.

S. interpres. Selby, pl. 33. f. 1, 2, 3. (fig. 319.)

- Of this type, if sueh it be, I know nothing, cxcept from the descriptions of Cuvier and Temminck. 
Numenius, Brisson.* Bill long, considerably arched, strong, hard: the upper mandible broader than high. Nasal groove extending the whole length. Nostrils lateral. Tarsus lengthened. The anterior toes margined and semipalmated; the hinder one raised.

N. arquata. Selby, pl. 13. Phropus. Ib. pl. 14.

\section{FAMIIY CHARADRIADE. Plovers.}

Bill short; the basal half soft, the remaining portion hard: the culmen suddenly elevated and curved. Nasal groove deep, extending to half the length of the bill. Feet long. 'The three anterior toes cylindrical; the hinder generally wanting.

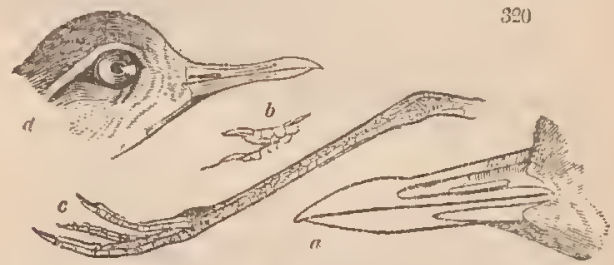

Sevatarola, Cuvier. Bill typical. Feet as in the Scolopacida. The anterior toes margined, flattened, and semipalmated; the linder toe very minute. The natatorial type? ( fig. 320. $a, b$ )

S. melanogaster. Pl. Enl. 853, 8.54. 923.

Charadrus, Linn. (fig. 320, d) Size small. Wings very long, and pointed; the first quill longest. Hinder toe always wanting.

C. morinellus. Selby, ii. pl. 59. f. 1, 2.

VANELlus, Brisson. Lapwing. (fig.321.a) Size large. Wings loug, ample; the four first quills nearly equal. Spines on the carpus, and naked lobes on

- It is obvious that this is the representative only of Tantalus; but whether it is one of the primary divisions, or merely a subgenus (in conjunction, perhaps, with Falcinelus), in the circle of llimantopus, must remain undetertmined, until we know more of the form of Oreopholus, and of the aftinities of Tachydromus, \&r. 

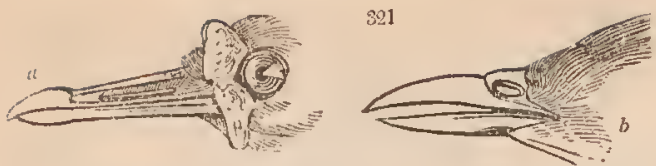

the head, arc on many of the species. Tarsus sometimes with a small hinder toe. (fig. 320.b)

V. cristatus, Selby, ii. pl. 34 .

EDicnemus, Thick-knee. Culmen scarcely depressed in the middle, hard and strong, its cntire length. Nostrils large, inembrana-

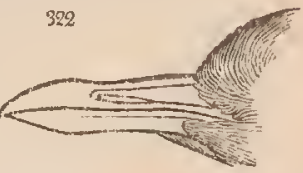
ceuus, not placed in a groove; the aperture large, oval, terminal. Tail longcr than the wings, rounded or graduated. Feet thrce-toed. The rasorial type. ( $f i g .322$.

O. crepitans. Pl. Enl. 919. Americanus. Part 5. No.203.

Tacnynrosus*, lliger. Courier. Bill short, slender. Nostrils short, membranaceous, not placed in a groove, naked; the aperture oval and lateral. Culmen straight as far as the nostrils, but curved beyond. Wings pointed. Feet three or four toed. The toes not flattened or margined.

Grarfola, Linn. Pratincole. Bill much compressed: culmen elevated and convex : gonys straight. Feet four-toed. Middle toe and claw very long; the latter greatly developerl, slightly curved, dilated, and obsoletely serratcl; inner toe shortest; hinder toe elevated, but touching the ground. Connected to Tachydromus by Tach. chalcopterus, Pl. Col. 298.

G. torquata. Selby, ii. pl. 63.

Tachydromus, Illiger. Courier. (fig. 323.) Bill broader than high at its base : both mandibles often curved : the

* There scems to me little doubt that these threc subgenera, however widely auart they have bitherto been placed, are closcly united; but the nutural affinities of the group, whether with the bustards or the plovers, is by no means determined. Is it not a fissirostral type? 
culmen slightly indented at the termination of the nostrils : gonys ncarly straight. Feet long, three-toed. The lateral toes very

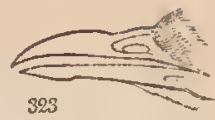
short; the outer connected by a membrane to the base of the middle toe; the latter very long, and the claw serrated.

T. isabellinus. Pl. Enl. 795. Burchellii. Part 5. No. 174. Orientalis. Part 5. No. 173.

Ammoptila, Sw. Bill lengthened, conic: both mandibles of equal thickness : gonys ascending; the cutting margins considerably inflected. Feet moderate, three-toed. Lateral toes and claws equal; middle toe rather short, the claw entire.

A. charadroïdes. Pl. Enl. 918. ( fig. 321.b)

\section{Order NATA TORES. The Swimmers.}

FAmiLx ANATIDA. Ducks.

Bill very broad; the sides furnished with lamellar plates.

SubFax. PHCNICOPTINA.

Legs very long. Grallatorial.

Phonncopterus, Linn. Flamingo. Size large. Bill thick, cylindrical, slort, abruptly bent from the middle: the under mandible considerably thicker than the upper, which is greatly depressed; the margins lamellar.

P. Europæus. Pl. Enl. 68. Americanus. Wilson, 66. f. 4.

Surfam. ANSERINE. Geese and Swans. +

Feet lengthened, moderate. Rasorial.

Cygnus, Antiq. Swans. Size large. Base of the bill tumid, fleshy, and naked. Neck remarkably long. Feet short. Hinder toe simple.

S. Bewickii. Selby, pl. 47*.

+ The subgenera of this group have not yet been determined. 
Anselk, Antiq. Geese. (fig. 324.) Size moderate. Base of the bill feathered, and considerably elevated in

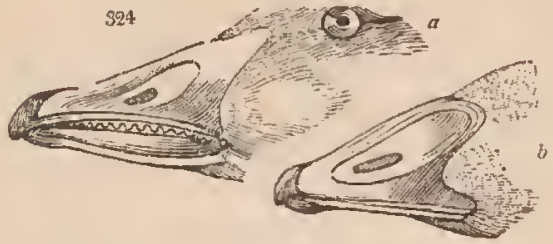

front. Nostrils large; the aperture central. Legs lengthened, placed in the equilibrium of the body.

A. Hyperboreus. Wilson, pl. Bernicla. Selby, pl. 44.

$$
\text { 68. f. 3. (a) }
$$

(b)

Dennrocygna, Sw. Tree

Ducks. Bill resembling that of a duck. Nostrils near the basc. Feet lengthened. The toes long, and projecting beyond the membrane. Claws long, slender, and

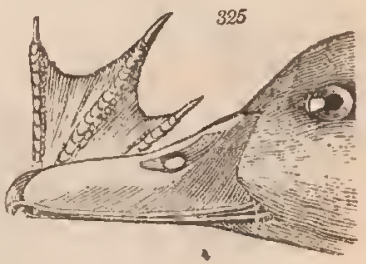
but slightly curved. Hind toe lengthened

D. arcuata. Horsf. Java. (fig. 325.) arborea. Edw. pl. 193.

Plectroptenus, Leach. Size large. Wings armed with naked tubercles or spines. Bill lengthened;

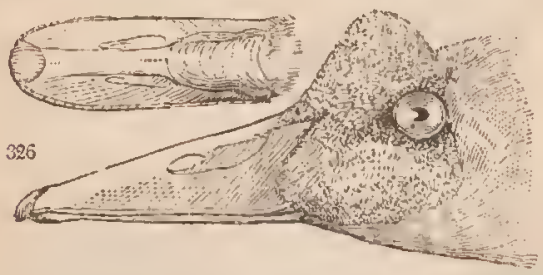

wide at the tip; the base with a naked protuberance. Rasorial.

P. Gambenses. Leach. Gen. Zool. xii. 2. 6. (fig. 326.) 
Cergopsis, Lath. Pigeon Goose. (fig.327.) Bill short, very mucl thickened at its base. Nostrils central. Tarsus with hexagonal scales. 'Toes semipalmated. The grallatorial type. C. australis. P. C. 206 .

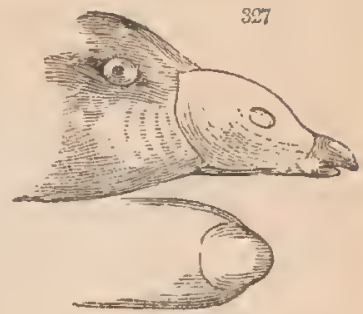

Sunfar. ANATINA, Sw. Niver Ducks.

Bill broad and lengthened Nostrils basal. Legs very short. Hinder toe sliglitly lobcd. (fig. 329.d)

Marrca, Leach. Wirlgeon. Bill very short and small, of equal breadth throughout; the tip not narrowed. Tail long, pointed.

M. Americana. Wilson, pl. 69. f. 4.

Dennronessa, Sw. Tree Ducks. (fig.328.) Bill small, short, rather compressed; the tip contracted. Nostrils towards the middle of the bill. Head crestcd.

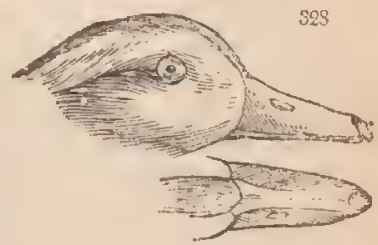
Tertial quills rccurved.

D. sponsa. Wilson, pl. 70. f. s. galericulata. Edx: pl. 210. ANas, Linn. Typical Ducks. Bill flattened trom the base, longer or as long as the liead; the tip broad, and never contracted.

Chauliodus, Sw. (fig. 330.b) Bill of equal breadth throughout. The lamina fine, but not much projecting beyond the margins.

C. Strepera. Selby, pl. 51.

Malacorynchus, Sw. ( fig. 329. a) Bill like the last; but the substance soft, and the tips of the upper mandible furnished on each side with a loose angular skin. Australia. 

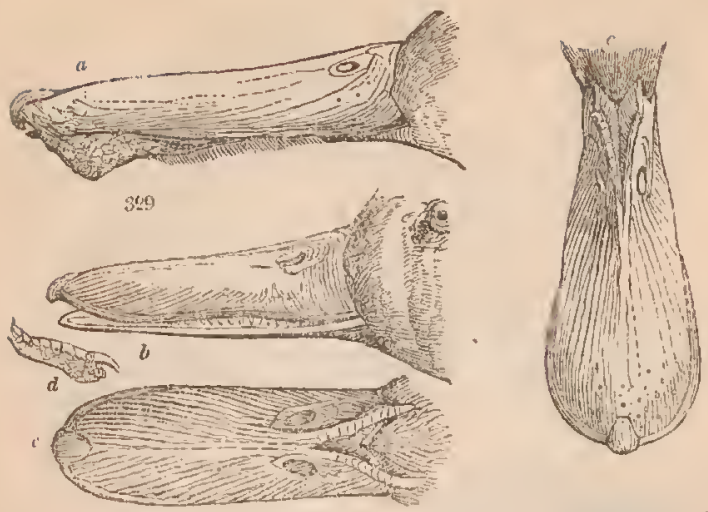

Anas, Linn. (fig. 329. c.330. c) Bill excessively broad towards the tip, narrowed at its base. The laminæ of the upper mandible slender, and consiclerably prolonged beyoud the margins. A. clypeata. PI. Enl. 971. Boschas, Sw. (fig. 329. $b, c)$ Bill of cqual breadth throughout. The laminaquite concealed. Nape of the neck crested. Tertial quills generally curved upwards.

B. domestica. Selby, pl. 50. 1.

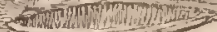

3.30
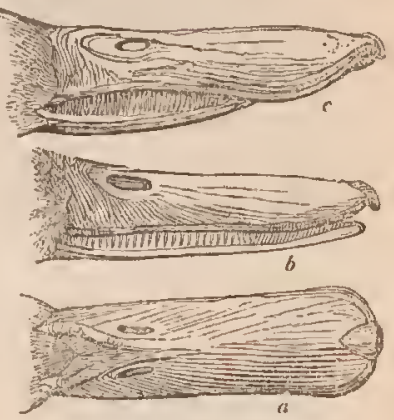
circia. Ib. pl. 53. crecea. 1b. pl. 54. carolinensis. Auct. discors. Auct. glocitans. Selby, pl. 55.

Dafila, Leach. ( fig. 330. a), Bill and neck very long. Lamina almost entirely concealed. Tail much lengthened and pointed.

D. caudacuta. Selby, pl. $51^{*}$. f. 2 .

Ts norxa, Leach. ( fig. 331.) Base of the bill considerably 
elevated, and somewhat tumid; the tip broad: the lamina not projecting.

T. Bellonii. Selby, pl. 48 .

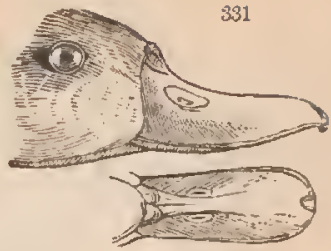

Subfam. FULIGULIN疗. Sea Ducks.

Hinder toe very broad. ( $f g .333 . d$ )

Somateria, Leach. ( $f g$. 332.) Base of the bill enlarged into compressed and elevated lobes. Tertial quills curved.

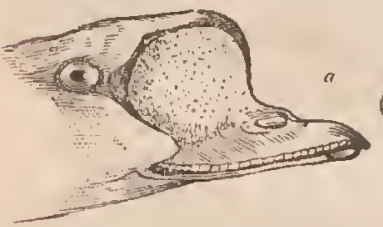

332

T. spectabilis. Selby, pl. 71. (a) mollissima. Ib. pl. 70.(b) Ordenia, Flem. (fig. 333.) Base of the bill high and turnid, but not forming lobes; the tip contracted. Tertials simple.
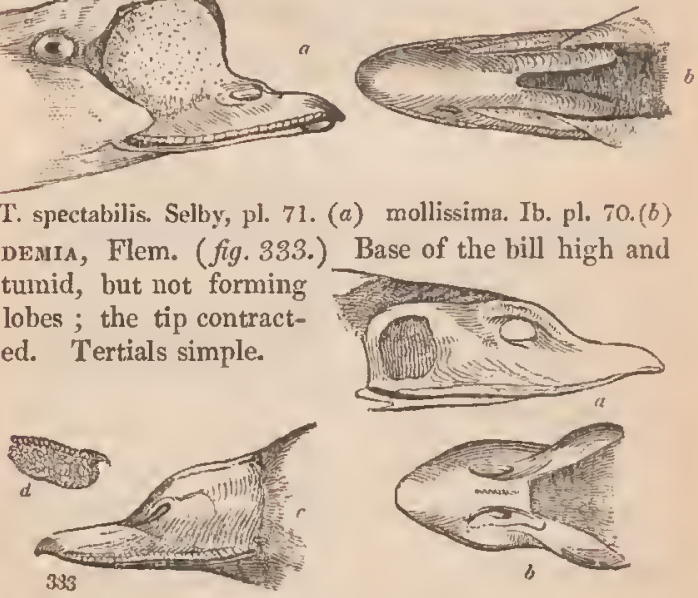

O. perspicillata. Selby, 69. (a) Fuligula, Ray. (fig. 334.) Bill depressed from the base; the tip abruptly and obtusely rounded, but not contracted.

F. Ferina. Selby, pl. 63. f. 1 . marina. Ib. pl. 66. (a)

nigra. Ib. pl. 68. $(b, c)$ 334

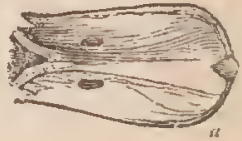


Clanguta, Flem. Bill elevated at the base, short, compressed; the tip roundci and contracted. Nostrils nearly 'central. Wings very short.

vulgaris. Sel. pl. 62. (fg. 335.)

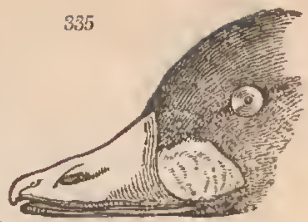

Haramda, Ray. Bill short, cylindrical ; the base not elevated; slightly narrowed towards the tip. Upper lamina remote, and rather projecting. Nostrils basal, large; the aperture long, oval. Tail cuneated. The two midde feathers very long. Probably enters the next subfamily.

II. glacialis. Edwards, pl. 1.56. Selby, pl. 61.

Subfam. MERGANID IE. Mergansers.

Bill long, narrow; the tip abruptly hooked. Fissirostral.

Mergus, Linn. (fig. 336.) Bill straight, slender, wide at the base, cylindrical beyond; the tip abruptlyhooked: the margins of botls mandibles serrated. Feet sliort, placed

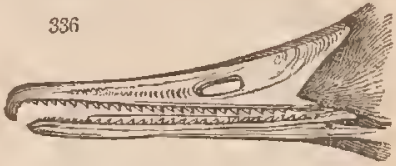
behind the equilibrium. Toes fully palmated. M. merganser. Sclby, pl. 57.

\section{Family COLYMBID E. Grebes.}

Bill more or less conic. Feet with the toes partly webbed and partly pinnated. Tarsus compressed. l'onlcers, Latham. Bill long, conic, very straight, acutely pointed. Nostrils in the middle of the nasal groove. Tail none.

P. rubricollis. Selby, pl. 72 . cristatus. Ib. pl. 53. f. 1,2.

Dasyrtilus, Sw. Bill short, strong: the culmen arched; the tip bent. Under mandible with the Vor. II. 
gouys very short and angulated. Quills internally cmarginated. Tail none.

D. poliocephalus. Ill. of Orn. i. pl. 13.

Podoa, Illiger. Bill moderate: the culmen curved towards the tip, which is notched. Wings moderate,pointed. Tail remarkably broad, and rounded. Rasorial. (fig. 337.)

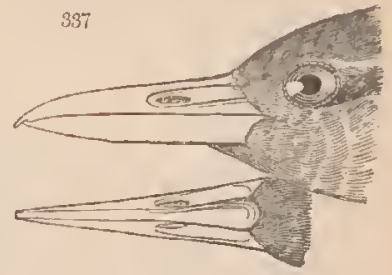

P. Suriuamensis. Pl. Col. 893.

Corvubus, Linn. Diver. Bill rather long, straight; the tips acute; the margins inflexed. Nostrils half closed by a membrane. WVings short, pointed. Feet with four toes, all connected by a palmated membrane, which is not lobed. The natatorial type.

C. glacialis. Selby, pl. 76 .

\section{Fanily ALCAD更. Autes.*}

Bill with the culmen more or less arched; the sides compressed. Feet entirely webbed. 'The hinder toe minute, or wanting.

UR1A, Brisson. Guillemot. Bill moderate, slender. Froutal pluines advancing far upon the nostrils, but divided by the culmen. Feet slencler, threc-toed. 'Tenuirostral.

'Troile. Pl. Enl. $903 . \quad$ 13runnichii. Tem. Man. ii. 926. Arca, Linn. Auk. Bill compressed and grooved as in the last genus, but longer than broad. Nostrils placed towards the middle of the bill. Wings abortive, fin-shaped.

A. impennis. Stluy, pl. 82.

Mormon, Illiger. Puffins. Bill short, very high; the sicles generally sulcaterl: the culmen strongly arched,

* The individuals in this group are so few, that I have not considered it expedient to adopt the sulagenera particularly as their natural series has not been worked aut. 
the tip hooked, and the gonys ascending. Wings and tail very short; the former capable of flight. M. Alle. Pl. Enl. 917. aretica. Sulby, pl. 83*. cirrhata. Pl. Innl. 761. Tordis. [1. pl. 83.

Cumenina, Fischolt\%. Bill. compressed, smooth; base naked; the tips notched. Upper mandible with an elevated, compresserl, hornlike protuberance above the nostrils. (Esch.)

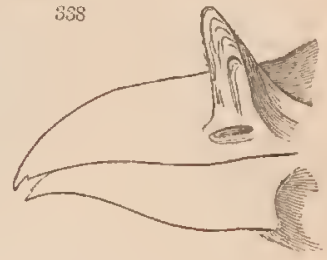

C. cornuta. Esch. Zool. Atlas. p]. 12. (fig. 337.)

Pharmerıs, Temminck. Bill short; the base depressed; the sidles nearly quadrangular. The tip notched. Feet short, three-toed. Claws much curved. Wings with the first quill longest. Rasorial.

P. cristatellis. 1'. Col. 200.

Aptenonytrus, Forster. Penguin. Bill long, slender; the base of the under mandible considerably thickened. Plumage scale-like. Wings resembling fins. lism sirostral.

A. Patagonica. Pl. Enl. 759.

Subar. Plizicanide. Pelicans.

Bill long; the base wide; the tip of the upper mandible suddenly and considerably hooked. Face more or less naked. Wings very long. Feet exceedingly sliort. All the four toes united. Fissirostral.

Plotus, Linn. Darter. Ncck excessively long. Bill perfeetly strait, and acutely pointed; the inargins finely dentated. Fissirostral.

P. Americamus. Wilson, 74. f.1,2. Africanus. Pl. Eni.107. Fachyeres, Vicil. Frigate-bivd. Bill with the tips of both mandibles curverl. Wings excessively long. 'The tail deeply forked.

T. aquilus. Pl. En\}. 961.

Canbo, Meyer. Cormorant. Bill resembling Tachy B $\mathrm{B} 2$ 
petes; but the under mandible is straight to the end, where it is truncated. Wings short. Tail hard, arıd rounded.

Cormoranus. Selby, pl. 84. cristatus. Ib. pl. 86.

Perroanus, Linn. Pelican. Bill long, straight, depressed; the tip greatly hooked. Chin naked, forming an extensible pouch. Middle claw entire. Rasorial.

P. onocrotalus. PI. Enl. 87.

Dvsporus, lliger. Gannet. Bill entirely straight; the base thick; the tip acute and compressed; the upper mandible sulcaterl. Culmen convex. Wings long. Middle claw serrated. Tenuirostral.

D. bassanus. Selby, p]. $86^{*}, 87$.

Strast. LARIDAE. Gulls.

Feet lengthened, formed both for walking and swimming.

Stwrna. Terns. Feet short. Wings and tail excessively long; the latter generally forked. Bill straight at the tip. Fissirostral.

Sterna, Linn. Bill slender, very straight: the culmen and gonysequally curved towards the tip. Conmissure straight. Nostrils basal, long, linear. Feet small, weak. Tarsus much shorter than the middle toe. Finder claw curved.

S. Hirundo. Sulby, pl. 90. f. 1. nigra. Ib. pl. 91. Thulassites, Sw. Bill strong: the culnen curved from the base: the gonys short, and hardly angulated: the commissure curved. Nostrils towards the middle of the bill, oval. Feet strong. Tarsus longer than the middle toe. The hinder claw straight.

T. magnirostris. Spix, pl. 104.

Pheton, Linn. Tropic-birk. Bill as in the last, but the margins dentated. 'Tail short, but the two middle feathers excessively long and filiform. Feet very short, natatorial: all the toes connected by a membrane.

P. phanicurus. I'l. Enl. 979. 
Rynchops, Linn. Bill cxcessively compressed: the upper mandible much shorter than the under.

R. niger. Wils. 60. f, 4. melanurus. Part 5. No. 175.

Gavia, Brisson. General structure of Sterna; but the tail is even or rounded.

G. leuroceps. PI. Lnl. 997.

Larus, Linn. Gull. Bill much compressed, straight, but the outer half of the culmen much curved. Gonys strongly angulated. Wings very long. Tail short, even. Feet moderate. 'Tarsi as long or longer than the middle toe. Hind toe very short. 'Typical.

L. tridactylis, 1'l. Enl. 387. Sabini. Lin. Tr. xii. pl. 29. rillibundus. Selby, pl. 92.

Llstris, Illiger. Jager. Bill moderate; the base straight, cylindrical, and covered with a cere, beyond which the culmen is arched, and the tip hooked. Gonys angulated. Fect slender, naked above the knec. Claws large, much curved. 'Tail graduated; the two middle feathers lengthenerl. Raptorial.

Cataractes. Selby, pl. 100. Richardsoni. N. Z. pl. 73.

Domevia, Linn. I'ctrels. Bill straight; the end abruptly looked. Nostrils tubular, opening in front, with the sides prominent and convex. Rasorial.

Procellaril. Bill shorter than the head. Tips of the under mandihle straight and truncated. No hind toe, but a short claw. Nostrils simple.

P. Capensis. Edwards, pl. 90.

Diomedia, Linn. Albatross. Bill much longer than the head : the under mandible truncated. Nostrils simple. No hind toe or claw.

\section{D. exulans. PI. Enl. 237.}

Halodroma, Illiger. Bill very short: the under mandible truncated at the tip. Nostrils internally in double tubes. Ficet short. No hind toe or claw. Chin with a dilatable pouch. Natatorial.

H. urinatrix. Pl. Col. 51\%.

Thalassidroma, Vigors. Bill modcrate. Both mandibles в 3 3 
curved at their tips. Nostrils in double tubes. Legs moderate or lengthened. A claw in place of the hind toe. Grallatorial.

T. cinerei. Selby, 102*. Anglorum. Ib. 102. pelagica. Ib. 103. f. 2.

Leachii. Ib. 103. f. 1. oceanica. Pl. Enl. 993. Wilsoni. Wils. 60. f. 6 .

Pachyptila, llliger. Bill broad, and considerably dilated at its base ; the margins with internal laminx. Feet three-toed. Rasorial.

P. Forsteri. Ind. Orn. ii. 827.

Drontas, l'aykull. (1805.) Bill longer than the liead, compressed, very straight, strong, depressed at the base. Gonys strongly angulated. Nostrils large, depresserl; aperture terminal. Feet long, slender, compressed. All the toes articulated on the same plane; the posterior long and free, the anterior palmated as far as their last joint. Claws depressed. Wings moderate, pointed. Affinities uncertain. The grallatorial type?

D. ardeola. Pl. Col. 362.

\section{NOTES.}

Iiv reference to the observations on I.eptostome, page 139., I may observe, that this bird seems to have been described in France (some time after the specimen in question passed into the possession of the Zoological Society) under the name of Saurothera Bottr.

The great delay in determining the apparently undescribed speeies enumerated in the systematic arrangement, and the lateness of their appearance, has prevented me from availing myself of some few ornithological puhlications; as the late Numbers of the \%oological Proceedings, Gould's Ornithology of New South Wales, se.

My suspicions that $T$. orienlalis was a tistinct specios from that foumd in Southern Africa, has been fully confirned by specimens of the latter just brought home by Dr. Sinith. MI. I.ichtensteiu has cvidently mistaken them for one, his measurements being those of the African, which he lias thought to be the same as the Indian. M. Temminck, anil Dr. Latham, have both fallen into the same error. As the easc, therefore, now stamls, I should propose that the Cape species be distinguished by the name of $T$ : Capensis. 
GENERIC NAMES NOT ADOP'TED.

Amblyramphus. Coriphilus. Apales, $S w$.

Ara.

Arara.

Aratinga.

Arinaria.

Artamus.

Bethylus.

Bubatus.

Bubo.

Calodera.

Calopsitta.

Calyptorynchus.

Campicola, $S w$.

Capito.

Cariama.

Cassiculus, $\boldsymbol{S} w$.

Catarrbactes.

Cephus.

Chamæza.

Charmosyna.

Chauna, Ill.

Cissopus.

Coccycua.

Colaris.

Collurio.

Coracopsis.

Coronica.

Corydilla.

Corydon.
Corythus.

Cracticus.

Creadon.

Crex.

Cursor.

Cursorius.

Cyclaris, $S w$.

Cymbops.

Cyphos.

Dasyptilus.

Dendrositta.

Dilophus.

Domicella.

Drepanis.

Edolius.

Eclectus.

Euphemia.

Eurynorluynchus.

Fedoa.

Ficedula.

Figulus.

Fratercula.

Gallinago.

Graucalus.

Guiraca, $S w$.

Hamatops.

Hydrobates.

Hypothymus.

Ianthocincla.

B B 4
Kampylorynchus

Kitta.

Laniarius.

Laniellus, Su.

Laniisoma.

Lanio.

Lobipes.

Lophyrus.

Macrodactylus.

Macroramphus.

Megalotis.

Melias.

Mergulus.

Micropterus.

Mimetus.

Nengetus, $\boldsymbol{S} w$.

Nestor.

Enanthe.

Onocrotatus.

Opœthus.

Ortigometra.

Parulus.

Pelidua.

Phalacrocorax.

Philydor.

Phimis.

Phropus.

Piaya.

Picumnus.

Pionus. 


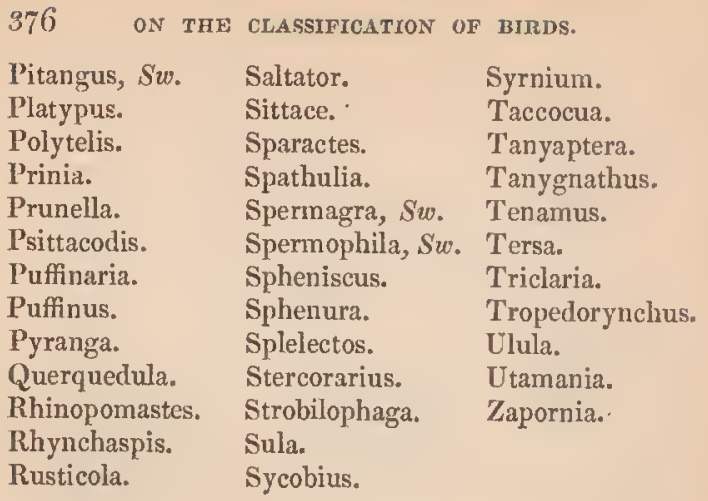




\section{N D E X.}

\section{A.}

ABBreviations, explanation of, 204.

Acanthiza Ilorsf. \& Vig., 62. Sub. generic character and spccies, 242.

Accentor Bechst., generic character ant species, 247. Capabitity of climbing observed in, 42.

Accipiter J'illugh., generle character and species, 214.

Accipitrinis, sublamily character and synopsis, 21.4 .

Acridotheres Vitill., beneric cbaracter and suecies, 270.

Fgithalus Fif.,.sulugeneric tharacter and specins, 246 ,

Eithina Vieill. subgeneric character and species, 246

AEgotheles Horsf. \& Tige, subgeneric character and spocies, $33 \AA$.

African beef-eater, its habits and characters, 103.

African drongos, 8 .

African grouse, 1 tiz.

African honneyguides, 139.

A gapornis satby, generic character and specirs, 301 .

Agelainie, 98 . Scu Maize birds.

Agelaius Fiesll. generic character and species, 275 .

Agelaius leterncephalus, 102.

Agelaius longipes, 101 .

A glais $S w_{0}$, generic charater and species, 285. Its plumage, 113. Charncters, 121.

Aglaina, subtamily, character and synopsis, 275 .

Agrobates Sq $9 ., 63$. (icncric claracter and specties, 24l,

Agrodroma Sw\%. generic eharacter and species, 292.

Arrophilus Srn., generie character and species, 291 .

Aimophíla Sw. subgeneric eharacter and specics, 287.

Alauda lin., generic eharacter and specles, 221.
Alaudina, 109. 124. Subfamily, character aud synopsis, 291.

Albatross deseribed, 373.

Albatrosses, their habits and geo graphical distributioll, 196.

Aleat Lin., 192. Gencric character and species, 370 .

Alculae, 184. 192. Family character and syzopsis, 370 . See Penguins.

Alcedo Iinz, generic clanacter, 335. Subgeneric character and speetes, 336.

Alceto ispids, its hablts, 154.

Alcyone Sw., subgeneric character and species, 336 .

Alecthelia Less., subgenerle chariscter and species, 358.

Alectors, eharacters, habits, and zenera, 162.

Alcetura, 90 .

Alecturus $r$ icill., gencric character and speciss, 256 .

Amadina Sw", gemeric character thd species, 279. Subgencric claracter and spectes, 280 .

American mocking-bird compared with the logecrhoaded shrike, 34.

Amrrican orioles, 101.

American reistart, $\$ 4.60$.

American wrens, 132,

Ammodramus Su, subgeneric character and species, 289 .

Ammoptila Sz\%, tsubgencric chan racter and species, 364.

Ampelida, 70. Taunily cliaracter and synopsis, 249 . ITheir affinities, 77. See Chatterers.

Ampelinne, 71. Subfamily charucter and syuopsis, 252 . Their character and habits, 74 .

Ampelis $L$ in., generic charater and specics, 253 . Its characters, 75.

Ampelis carnifex, 76.

Anahacnus Sw., generie eharacter and species, 324 .

Analuates T'm, generic character and species, 317. 
Anabatinze, 331. Subfamily character unil synopsis, 315 .

Analogies in larcer groutps pass into close aftinities in smallor ones, iff. ; amwue the arders of birds, the tribes of perehers, and the subfatmilies of warthlor, 69.; of rasorid birts, with hootiod quadrupleds, $15 . \%$; of the antthruslies with the oriers of birds, 27.; with the lusessores, 29. : with live Lentirostros, 2!) ; of the ant-chroshes with the Thamnophiltua, 30.; witl the I.aniade, 30 , ; ol tbe atit-klirushes with the trilues of the furcbers, 33.; with the abrikes, 31.; with the honoy-suclsers, 37, : between Chatolslenma atul P'riomups, 1 .; hetwen Falcurculus frontalis and the renas 1"arus, J2,; of the tinclies and starliugs, 109.; of the soitsurkels, 15\%; ; ol the nightingale warblers, fit, ; of the orfoles, 21 . : of tise pigeons with the waders, 170 ; hetwen Pitta cyanura and Cinnyris Scnegallensis, $3 .$, l between the Brachypodiua ind Meliphagidæ, 3\%, ; of the shrikes, J4. between the shrikes and falcons, 3. : nmongst the generd of Syrleoline, the types oi Siylvicolin, and the tribes of Insessores, 55.; of the scarlings, lo3 -107 ; of the Sylviane to the perclit'rs, fis.; of the genus $S y l$. vicola, 51. ; of the sulugenera of Sylvicola and 1'arus, 52. ; of Todus, si. : between the sub. fumilies nt the warblers and the tribes of perchers, 68 ; between the warints and perchers, 179.

Analcipuz Sir., subzenerle character and specles, 221. Plunisge of, 7 .

Auas Lum, generic character and species, 365, stubeutric chatricter and specles, $36 \%$.

Anas clypearn, 189.

Anastomu $1 / 1$, i74. Cieneric charactor aud sjucles, 356 .

Anatida, 18.4. Fuinily character and synopmis, 364. See Irucks.

Anatina, 189. Sinbfimily character and symopsis, 360 .

Andropactus sin, subgrneric cla. racter and species, 227 .

Andropalus familiaris, its fumimiliarity, 21 .

Ani, their habits, 161.

Anser Artiq., 191. Generic character and species, 365 .

Anserina, subfanily.character and synopsis, 364 .
Ant-thrushes, 18, 20. Synopsis of, 229. Characters, habits, and natural arrangement, 24. Analogies of, 27 .

Anthoulaera Horsf. \& Fig., subgeneric eharacter and species, 326.

Anthomyza, generic claracter and species, $327^{\circ}$.

Anthreptes $\$ w$. generic character and species, 32 ?

Anthropoides, 173.

Antluus Bechst., generio character and species, 248. Its eliaracters, analogy, and afinity, 40.

Antlius pars Auct., 292.

Apails, 63.

Apaloderma $S u$, subgenerie character and species, 337.

Aptrnodytes Furst., genelic cha. racter and species, 37 !.

Aptenudytes chrysocoma, its mode cil progression, 193.

Apternus sw., stugeneric cliaractor and specics, 316 .

Apternyx Shaw, subgeweric character and species, 346 .

Aquili, generle character and speries, 20\%.

Aquilinx, subfamily character and syuopsis, 206

Aruchnothera Ton., generie character and spiccios, $32 *$.

Aranus Ditil. generic character and species, $35,60$.

Aretic gulls, I!6.

Arotic puffin, 142.

Arde' $I$ in., generic claracter. 333. Suhgeneric cliaracter and species, 353.

Ardea pavonina, I73.

Ardoadx, 172. Family elinracter and synopsis, 3.73. Sife Iterons.

Argus $l ' m$, subgeneric tharacter and ㅁpecies, 311 .

Argus pheasant, Its plomage, 166 .

Arremon trievl., stibgeneric character and species, 288 .

A sio Antio., gencrle cliaracter and sluecles, 247.

Aster Auct, generic cliaructer and spreeiss, 21.3 .

Astlimurus, Ste., generle tharacter and speciles, 311 .

Astlienurus minutus, 136 .

Astrapla $/ 7$ icill, generic cllaracter and species, $2 ; 2$.

Astrapia mularis, 98 .

Auk dicacribed, 370 .

Auks, synopsis of, 370 .

Aulacorjnchus Gould, generic character and species, 249.

Australian lantails, 54 .

Australian robin, 65.

Australian satin-birds, 99. 
$A$ viceda $S u$, generic character and species, 213.

Avosets, 177.

B.

Babblers, synopsis of, 233.

Baker-bird, 66 .

Balassian swift, I5l.

Barbuts, characters nnd habits, 135. Synopisis ol, 311.

Baryta Cuv., 15. Generic character and species, 263.

Bearded tit, 43.

Bee-eaters, their characters, habits, geogriulical distrihution, and affinities, 15\%. Synoysia of, 332 .

Bengaly deseribed, 270 .

Bentivi tyrunt, plumage and labits or, 12.

Birds, synopsis of a naturnl arrangement of, 201.

Bitterns described, 354 .

Black and white crecper, its chinracters, 4\&. Aftiuity with the pitutcreeping wartler, 49.

B)ackbird, bahits and characters of, 17.24.

Black-capped warbler, 64 .

Blitck-calx, syuupsis of, 253.

Blackpole wartiler, 59 .

black-tord gulls, 196 .

Blechropus Sw.. subgeneric character and species, 250 .

Blue-bird, 65.

Blue yellow-backed warbler, 51.

Boatbills, 173.

liont-tails, their plumnge and geograwhical position, and the origin of their nause, 98. Synoysis al, 272.

Bombycilla Triss., genaric chinracter aud splecies, 251.

Bombycilla garrula, 70 .

Bombycillina, 73. Sulfamily character antu syonopsis, 251 .

Boschas Sw., subgenerice eharacter and suecies, 367 .

Botilbul of Inclia, not the Furopean nightingsile, 20 .

Brachylorluis, Sw", subgeneric character and species, 3108 .

Brachyputes Sw., suhpenteric chil racter and species, 334 .

Brachypoline, 18. 23. Sublimily character and symopsis, 226. See Short-legged 'Thrushes.

Brachypterix Ilorsf.. subgeneric character and species, $22 \%$.

Brachypus Su., i\%. Generic chiracter, 228 . Subgenerie charaeter and sjecies, 227. Plumage of, 19,20 .
Brachystoma Sw., 97. Generic character and species, 266.

Braconyx Sw., subgeneric chisracter and species, 292.

Bradyjterus $\$ w .$, generic character and species, 241.

Brazillitu tiumice, 43.

Bristle-neck descrihed, 228.

Bristle-necked thruslies, 18.

Hroadbills, symopsis of, 260 . Their characters, 81.

Brotogeris Fig.; generic character and epecies, 303 .

Bucco Iin., geueric character and speties, 311 .

Buecoina, 135, subfamily character aud synopsis, 311. See Barbuts.

Buceridat, 93. Family character and syuopsis, 298. "Sec Hornbills.

Buceros Lin., generic claracter and speries, 298.

[suceros galeatus, 129.

Budytes Cav., 40. Generic character und sperins, $24 \mathrm{~N}$.

Bultinches, synopsis of", 293. "Thelr charitete'?, 125.

Buntings deserlbed, 2\$9.

Huphaga f.ath., 103 . Generic character and species, 323 .

Tuphaginz, J31. Subfamily tharater aud synopsis, 320 .

Bush shrikes, 4. Synopsis of, 220. Charater's and hatbits of, 9, 14.

Bush warblers, their eharacters, 46. 48 .

Bustards described, 345 .

inteo Anfig., generic character and syecies, 211.

Buteoninx, subfanily character and symopsis, 210.

Butor Anliq., subgeneric character and species, 353 .

Buzzards, syuopsis of, 210 .

C.

Calendula Jin., generic character and sjecies, 292.

Calurus $S w_{n}$, subgeneric character and species, 337.

Calyptomina Raffles, 75 . Generic character and species, 252.

Calyptura $S w$., generic character and snecies, 254.

Calyptura cristata, 76 .

Campephaga Vicill., generic character and species, 223 .

Camphylojterus S $w$, I48. Generic character and species, 330.

Cancroma lin., 173. Generic character and species, 355 . 
Capita Vieill, subgeneric character and species, 334.

Caprimulgida, family character and synopsis, 338.

Caprimulgus Lims, generie character, 33y. Subgeneric character and sprefes, 339.

Caprinulgus diurnus, its habits, 151.

Carho $M c y \cdot$ generic cluaracter and spicies, 371 .

Carduclis Rriss., generic character and species, $2 \$ 0$ ).

Carduelis Americana, 113.

Casmarinynchus, family, 75. Generic character and spccies, 252.

Cassicans describod, 273 .

Cassicus Doud., gencric character and species, 273 .

Cassowary, 168. Described, 345.

Casuaring Liny, subgeneric charac. ter and species, 315 .

Caternfllar-catchers, 7. Synopsis of, 223 .

Caterpillar-catching shrikes, their strong reseublance to the ortoles, 35 .

Caterulliar-eaters, 4. Characters, labits, and atinitieg of 7.15 .

Cathurtes III, generic character, 205. Subgeneric clatrater and species, 205.

Catheturus $S w^{\prime}$, generic character and species, 206.

Ceblepyrine, 4. Subfunily wharacter and synopsis, 2zis. Sec Caterpillar-eaters.

Cellepyris Ciev., generic eharneter and speries, 223. Its inalogy to Monacha, 83.

Centrecircus $S w .$, suhgeneric character and suecies, 34 .

Centropus IIL. 139. Generic character and specins, 323.

Centrourus $S \%$.. Rentric character and species, 303 .

Centurus \$w. subgeueric character and species, 310.

Cephalopiterus Geoff., goneric chitracter and species, 26s.

Cereopsis Lath. senteric character and species, 360 .

Ceriornis sis., generic chatracter and specirs, 341.

Certhia Lin., 16, fieneric charater and species, 31\%.

Certhia borbonicn, $4 \%$.

Certhia familiaris, 181.

Certhinde, 129. Family charactor and symopsis, 312. See Creepers.

Certhinne, 131. Subfamily character and synopsis, 312 .

Certluilauda Sw., generlc charac- $\because$ ter and spccies, 293. Bill of, 125

Cayx Lacep., subgeneric character and species, 3 tin. $^{2}$

1 Chatneza, plumage of, 25 .

Chrotoblemtna str. \&. in. 13. Generic character and spccies, 219.

Chatops Sw., 24. Generic character and species, 233.

Chatopus Su, subgencric character and species, 344.

Chatura, 152. Subgeneric character and specites, 3ito.

Chalcites Less., generic character and spocies, 322.

Chanepelia Sto., subgertertc charactcr and species, 389.

Chanltodus $5 w_{n}$, subgeneric cliaracter and species, 3 if

Churidriade, 172. Fumily cbaracter and species, 362. See Plovers.

Charadrias Lith, 175. Generic character and species, 3ri2. Its analogy to Blonachii, 83.

Chattorers, synopsis of, 219. Their subfamilies, 7l. 'I'beir characters and habits, 70 .

Chili plant-cutter, its habits, 126. 128.

Chimerina Escholls, generic character aud spectes, 371 .

Chionis Forst, generic character and speeies, $3 \pi 0$.

Chizaerhis Tharl., generic character and species, 297 .

Chloris, subgeneric character and specles, $2 \times 1$.

Chorisoma sw. Eencric character and specics, 230. Characters, ulumage, and affinitics, 2.5 .

Chluronerpes Su., subgeneric claracter and spectes, 307.

Chloropsis ofurd. \& sitlo, 20 , Subsyeneric character and species, 227. Tongur at, 37. 20.

Chloropygit Sm., gencric character and species, 8333.

Cliondestes Str., subgeneric charitcter and species, $2 \times 9$.

Churdeiles Sw., subenactic charuter and species, 339.

Clirysulophus sin., gencric tharacter aul species, y:2.).

Cirrysomus Sw. generic character and speciss 27.1.

Chrysonotus Si"., subgencric character and species, 309.

Chrysopteryx Su., generic character and sperdes, 252.

Chrysoptilus Sw., generlc character and specles, 307. Subreneric elaracter and specics, $3 \cup 8$. Its characters, 134. 
Chrysotis Sul, gencric character ind species, 300.

Cicinnurus Visill, generic character and species, 331 .

Ciconia $B t^{4}$ iss.. generic clatracter and species, 355 .

Ciconia gigantea, 174.

Cinclus Bichst. 25, 27. Generíc character atul species, 231. Anulugies, $25-31$.

Cimuridac, 142. Family charneter ani synopsis, 32\%, Sce Sunbircls.

Cinnvris Cew., goneric character and species, b...

Cinnyris Senegulensis, its plumage and analogy with Pitta cyane'b, 35

Circaictus Ficill, igcneric character and species, 2018.

Ciresis Bechit., gentric eharteter and species, 2 lI.

Cissopus, the mame eancelled, 117.

Clangula Flem., treneric character and species, 3hit.

Climacteris $J^{*} m .$, genorie character and spucies, 318 . Mysticalis, 130.

Climbers, syuopsis of, $2 ! 1 \mathrm{k}$.

Coccoborms Sw., suligeneric charactes and species, 277.

Coccolonis mathentrostris, 111.

Coccothraubl's Briss. generic clatracter and sifectes, 277 . Siubgeneric cliaracter inil species, 277 . Itg sulugenura, I10.

Coccothrausthze, I IN. Sulsfimily cliaracter and sy nopsis, 276. Sec Ilarditilis.

Coccyzina, subfamily character and syntu\}sis, 322.

Coceyzis Fill., 138, Generia character anil species, 323.

Coccyzus Delalanui, 139.

Coccizus Genlfroyt, 139. 162.

Cuck of the rock, 70. 167.

Cockatons, synopsis of, 302.

Colaptes Siw., gemeric character. 3.9. Subzenerie character and species, 310 . Its cliaracters, 135.

Colinix, subfamily character and synopsis, $296^{\circ}$.

Colius $L$ in., generic charmet er ambl species, $2 i 6$.

Collared stirling, 100.

Colluricincla $V$ ig., generic cbaracter and species, 221 .

Collurisoma, 10, 3i.

Columba Lim, generic character, 318. Subgeneric character and species, 348 .

Columbidie, 168. Family character atid synopsis, 316 . See Pigeons.
- Columbinx, sulfamily character and synopsis, 346 .

Colymbida, 184. Family character and synopsis, 302. Their characters, hatits, and geograjhlical distribution, 191. See Divers.

Colymbus I.in., 191. Generic charicter unil species, 370.

Conirnstres, charueters of the tribe, 92. Primary divisions, 93. Variation in size, 129. S'ynopsis of the generil of, 262 .

Conopophaga Ficill, subgenerie character :ud species, 258 . Jts cluaracters, 86 .

Conurus Kuhl. generic character and species, 300.

Coot described, 3.5\%.

Coracias Iin., 152, Generic charister and species, 330. Its true place, 97.

Coraciua Jieill, generic character and species, 257 .

Coracine, U15. Subfamily character and synopsis, 267.

Cormurant deseribud, 371. Its mode of feeding, 18y. Employed in lishing ly the Chinese, 194 .

Corvida, 95. Family charater and synopsis, 262. See Crows.

Corvine, subfamily character and synopsis, 26\%. Their hahits, git.

Corrine shrike, 13.

Corvis Zin., 44, Generic chartuter and suecles, 262.

Corruts grmnocephalus, 97.

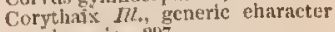
and species, 247 .

Colythiais persth, 161 .

Corythus Cuv.. generic eharacter and species, 295.

Cossypha Fig, subgeneric charucter anil species, 232.

Cotiugtt, 75, 76 .

Coturnlx Briss., subgeneric wharacter and specirs, 344.

Courier rlescribed, 363.

Conriers, 175.

Cowpen descriled, 276 .

Cow-bunting, 102.

Cracidia, 162. See Alectors.

Cranes, 172. Synopsis of, 353 .

Crateropotina, 18, 23, 24, 32, Subfamily charicter anil synopsis, 233. See Long-legged Thrushes.

Crateropus, 23.

Crax Lin, generic character, 352 . Subgeneric character and species, 352 .

Crcevers, synopsis of, 312. Their aftinitios, 130. Geographical clistribution, 131. Subfamilies, 131. 
Crescent larks, their plumase, 124.

Crest-crowned pigeon hen, 169.

Crested turush, 78.

Crestlet described, 250.

Crimson horabill, 94.

Crithagra, $\$ u_{-3}$ sub-generic charace ter and spectes, $3 ! 4$, Its plumage, 126.

Crotophaga $L$ in., generic character and species, 324 . Its habits, $16 \mathrm{t}$.

Crowahird desertued, 349.

Crows, synnpsis of, 262 . Subfamilies ol, 96.

Crypsirina V teill., goneric character and species, 260 .

Crypstrina temmura, 100 .

Crypsirine, 96.

Crypticus Sw., gonoric clnaracter and speesies, 33\%.

Cryptolopha $S \%$, subgeneric cbaracter and species, 250 .

Cryptonyx $T e m$, I $16 l$, Cioneric character aull suecles, 343

Cryptarus $1 / 1$. gencric eharacter, 345. Subgeweric character and speciss, 34 is.

Crytura, 72.

Cuckows, synopsis of, 321. Their habits and genrraphical distribution and atlinitio's, 138.

Cuculida, 129. Fimily character and synopsis, 321 . See Cuckows,

Cuculiua, subfamily, character and syousis, 321 .

Cuculus Lin., genaric character and synopsis, 321.

Culicivora $S^{\prime} w$, 61. Generic etusracter and species, 243 .

Curassows, 164.

Curlews, 176.

Curruct $B_{t} c h$ st., gencric character and species, 204.

Curruca, 63.

Curruca ineruloides, 64 .

Cushews, 164.

Cyanotus $\$ w$. subseneric character nud species, 243.

Cyranurtis Sw., generie claracter and sprecles, 2 ins. $^{\circ}$.

Cyclaris, tho name cancellod, 14.

Cygnus Antig., 191. Cenerte character ard speoios, $3 \%$.

Cymbirynchus Tig., rencrie character and spectes, 2ijl.

Cymiadine, subtamily character and symoysts, $20 \mathrm{k}$.

Cyuindis licill., generic eharacter and species, 209 .

Cynantlus Sw., 147. Tcueric character and spocies, 330 .

Cypselus Arist, 151. Generic chartucter, 339. Suhgeneric character and spccies, 340 .
D.

Dacclo $L$ çach, subgeneric character anal species, 3,55 .

Dacnis, Aij.

Dafila Leach, subgeneric character and spercles, 367.

Darter describued, 371.

Darters, their liabits and geographical distribution, 194.

Dartiond warbler, 62 .

Dasyccphaln Sit.,8. 25. Ceneric chinacter and species, 22\%. Pro. bable hithits, 27. Amalogies ol, $28-31$.

Dusyluphus $S_{k,}$, generic character aud species, 324 .

1) itsyptilus Sit., sencric character and species, $36 \%$.

Demoiselle crane, 173.

Dendrobates Sw., sulngeneric character and species, 306 .

Deudroculaptes $\| l l$. generic tharacter, 313. Subgeneric character and species, $\$ 13$.

Dendrocol's Sw, subgentic character and spocies, 314.

Dendrocopus isu, , sathgtelleric character and specios, 307 .

Dendrocygnit Sw", quueric character and species, $36 i$.

Dendromat Sw., generic character and species, 316 .

Dewdrumus sm., subgenerir character aud species, sth.

Dendronesta siv, generic charatter and species, 3tit.

Dendrophila Sv., generic character and specios, 318.

Dendroplex $S w$. sulogenoric charucter aud species, 314.

Dentirustres, symopsis of, $21 \mathrm{~s}$.

Dertroides \$w., sulngenere charucter and suevies, $27 x$.

Diagram ol the ornithological rir. cie, 200 . Illustratiou of the analogies of the crows and st:trlings. 107 .

Dlceun С" charicter aud species, 330 .

Diculophus Ill., getieric character and species, 351 .

Dicrurina, 4. Sulufamily character and synupsis, 221. See Drongo shrikes.

Uicrurus fricil., reneric character and species, 223.

Diomedia Lin, , 196. Generic character, 373. Subreneric clitracter and species, 373 .

Diver destribed, 370 .

Divers, 191.

Dolichonyx Su., 102, Generic character and species, 275 . 
Domestic fow 1,166 .

Donacobius $S w .$, generic character and species, 236 .

Dromas Payk., 197. Generic character ami speries, 374.

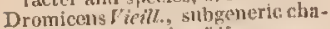
racter and sleccies, 345 .

Drongo shrises, 4. 1\%. Synopsis of, 221 . Characters, hablts, and affinitics of, $7,8,15$.

Drymoica Sw., 62. Subgeneric chararter and species, $24 \%$.

Drynophilin $\$ W_{0}$, situgeneric cliaracter, 230.

Dryotomus Stw subgencric ebnracter aurl specics, 308.

Ducks, syunosis of, 304. 'Their characterk, 188. Divisions, 1N8.

Dulns Vieill., generic character and species, 234 .

Dumccola Sw., 45. 53. 6il. Subgeneric eharacter ant species, 244. How soparuted from the fly-catching warblers, 633 . See Bush warblers.

Dumecola ruficauda, 46 . Its aftinity with Mniotilta varia, 50 .

Dysporus $11 /$., 194. Generic character and sjecios, 372 .

Dysornithia Sw., generic clitricter and species, 266 .

E.

Fagle owls described, 247.

liagles, synopsts of, 207.

lictupistes sw., subgeneric character and species, 348 .

Tdolius Cuv., 8 .

Tigithalus, 43. 45. Its close resemblance to Parus, 57.

Figithina, 43.

F githina lcucoptera, 53 .

legrets deseribed, 353.

Egretta Briss., subgeneric charitcter and species, 354 .

Eiders, $1 \times 9$.

Pidonsarus $\$$ w., subgeneric character nud specics, 327.

Llanus Sar.. snbgenerfe character and speries, 210.

Einberiza Lin., generic cluaracter, 289. Subgeneric charncter aud species, 259.

Linu, I68. Described, 345.

Suglish pullin, 197.

Euicurus Temo, 66. Cieneric character and species, $24 x$. Its plumage, 40.

Entomiza $S t \%$, reneric claractor and succies, 328 .

Entomyra cyanotis, J30.

Eopsaltria Sw., subgeneric character and species, 250.
Epimachis Cuw.,generic character and spccies, 331 . Its true place, 97.

Virucivora $S w$. , generic character and species, 224.

Firythaca ruberoli, 65.

Lrythombrys Sa, generic character and suecies, 322.

lirythrostomus Sw. generic character and species, 300.

Erftura Swo subgeneric character and specics, 280 .

Fistreldil Sw., subgeneric character and spreciss, 280.

Eudynamis llors. \& Fig., generic character and species, 322 .

Espliontia Jitill., subgeneric chnracter and species, $2 \times 0$. Its voral powers, 114. Distinctive characters, 121 .

Euplectes siv., 112. Snbgeneric charater and species, $27 \%$.

Funlertes capensis, 111.

Huropcan lee-cater, its habits, 152 .

Europeatu chatterer, its pliaracters, 74.

Eurylaimina, 80. Subfanily chan racter and synopsis, 260. Sice Broad-bills.

Euryluhnus Ilorgf., 80. Generts: charactes and spencies, 261.

Lurypygia IIl., generic charater tund species, 359 .

Lurystomus Heill., 152. Subgeneric character and specles. 333. Its true place, 97 .

\section{F.}

Friry oriole, its plumage, 22.

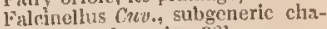
racter and species, 301 .

Falco Auct., generic character aml species, 212.

Falconidac, fmmily character and synopsis, 206. Subtamily charaster and synopsis, 212.

Faleons, synojsis of, $2060.21 \%$.

palcunenus ficill., 8. 13, 14, 13. Generic character and speeies. 219.

Fidcinculus cristatus, plumage of, 12.

Falcunculus frontalls, habits of, 11. Repres'rits the titmice, 12.

lialcunculus Guianerssis, 14.

Fan-tailed Aycatchers, their chararters, 84 .

Fieldfare, habits and characters $0 i^{\circ}$, 17. 24 .

Finch crows of India, 97.

Finch crows of India, 97. . Their analogies, 107. General charac- 
ters, geographical range, and primary divisions, 108 .

Fishl hawks described, 215 .

Fissirostral birds, synopsis of 332.

Fissirostras, 150, Chariteter and synupsis, 3i2. Their characters anit haluits, 151.

Flamingo deseribed, 361 . Its characters and innitogies, 190 .

FIuvleola Sw., 80. Gencric cha. racter and species, $251 f$. Its chariacters, 90 .

17uvlcola curkorial, 90.

Fluvlcolina, 5, 21,89. Subfamily character :mul syuojsis, 256 . Sce Water-cliats.

Fly-cuttchers, 5. Divisions of, 80 . synopsis of, 254. 257. Their characters and liabits, 73. Geographlic rauga, $8(0)$.

Flycatching w relers, their liabits, 53. How ke parated lirom Dumecoln, 33. Wescribed, 244.

Fork-tailed tyrants, 7, 8, $y$.

Francolin rescribed, àts.

Frigate-bird deseribed, :371.

Frigate pelicans. their habits and geocraplicad distribution, 194.

Frigiliue, 96. Sulffanily character and synopsis, 2 tis.

Frigilus, !5.

Fringilla I.tin., generic cliaracter. 288. Subgent:ice character and species, $2 \times s$.

Fringilla Zena, $11 \%$.

Fringillaria Site., generic character and sriecles, $28 \%$.

Fringilide, 107. Famliy character and syoopsls, 276. See Fiorhes.

Fringillinæ, 109. 122. Snbfanlly character and syoopsis, 27 . See Trye finches. 122. See Ground finches.

Fruit crows, synopsis of, 267.

Fruit-caters, synopsis ol, 249.

Fulica l.in., generic character and specics, 3.75 .

Fuligula Ilny, generic character and species, zik.

Fuligulinar, 189. Suthamily cla3racter and sjnopsis, 36*.

Fulmar. 197.

Furnarius Vicill., 6i. Gicneric character and specius, 315.

G.

Galbula Lin., gencric claracter and species, 3336 .

Galbula grandis, bill of, 156

Gallinula $A$ uet. generic character and species, 358 .
Gallus Antig., gencric character, 342.

Gallus Bankiva and $G$. giganteus, procenitors of the common domestic tow l, 160 .

Gampsonyx Ijg., subgeaeric charitcter ind speries, 210 .

Gimnet, 194. Described, 372."

Garrulina, 06. Subfamily claracter and synopsls, stit.

Garrulus IFillagh., generic character and speries, 264 .

Gavin Briss.. subgeneric character and species, 373 .

Geese, 191. Syllopsis of 364. Described, 365.

Cenerlc names not adopted, list of, 375 .

Geobates Sun, subgeneric charac. ter and species, 315 .

Geocolaptes, suhgeneric character And species, 369.

Geopelia Su., subgeneric clarncter and species, $\mathbf{3} 8$.

Grositta sw., meneric clinracter and species, 317 .

G]ireola Lin., 175. Gencric character and species, 363 .

Glasucopima, 96. Subianily cliracter and sy"nopsis, 265.

Glaucouls Forst., 97. Gencric claaracter and spectes, 267.

Gliciphila Sw. generic character stnd species, 32 ij.

Cinat-suappers, character and habits, 61 .

Gold-crests, their hnunts and food, 39.

Golden bird of Paradise, 22.

Golden-crested wren, bi.

Golklen eyes. 1:9

Golicn orlole, lts plumage and bathits, 21. Its nest, 22.

Goldfinch deserlbed, 2kil).

Goshawks deserlbed, 215.

Gracula Auct., generic cluracter and species, 260 . Its true place, 97.

Gricula religiosa, 9\%.

Grakle described, 271 .

Grakles, synopsis of, 27n. Their pectiliar characters amd acographicral range, 90.

Gralliuria rievill. generie claracter and species.231. Its jhmmate, 25.

Grallatores, 33.) 171. Character nnd synopsis, 353. See Waters.

Great auk, 192.

Greater tyrant shrikes, halits of, 6.

Grentinots, strnopsis of, 350 .

Grehes, 191. 'Synopsis of, 360.

Grcenfinch described, 281.

Green swallow of Brazil, 74 .

Greenlets, synopsis of, $24, j$. 
Ground cuckows, their hind claw, 139.

Ground doves, their hahits, 169.

Ground finches, synopsis of $f_{3} 7$. Ilabits aml charater, 12\%. Geugraphic distribution, 123.

Crouse, 166. Synopsis of, 343 .

Cryllivura, 65.

Gryllivora longivauda, 6f.

Gryllivora saulitis, Gi.

Cuans, their characters, 162.

Gubernetes $I_{7 g}, 93$. Generie clizracter and succies, 2515 .

Cubernetes foricatus, !1.

Guillemot described, 3 个3.

Guillemots, 19].

Guinca fowl, 16i, Describet, 342.

Gull descrilued, 373 .

cills, synopsls of, 372 . Their charactcrs, liabits, and geogrtiplical distribution, 195.

Cymnoceplistiss Geqd/., generic chnracter and spocles, 208.

(iymnophrys Sur, subgracic clia. racter and suecios, 327 .

Gypactus Stor\%, gencric character and species, 206.

Gypogeranus IIl., generic claracter and species, 208.

II.

1 lamatopus $L_{i n}$, generic cliaracter and species, 3.55 .

Hamatornis $5 w, 20$, silugeneric characte'r and spectes, 228 .

lizmothous Sil., geberle character and speries, 245

Hitlatrona, 1!ti. Subzeneric ohaand specios, 373 .

Halcyou Sim., generic character, 335. Suhrencric chararter and species, 33.5 .

Halcyonidx, 153. Family churaeter and synopsis, 334. Shed Kingfisliers.

Ilaliæetus sav., generic charucter racter and species, 215.

1 langnest titmiee, 43 .

liangnests, syvopsis of, 273. Their habits, chiracters, and geographical ranye, 102.

Haralda liay, reiseric charactior and speries, $36 \%$.

llard-bill, synupsis of, 276 . Their habits and sharaters, 110.

liarpactes sim., subgencric character and species, 337.

Harpagus fig., generic claracter and spoties, $2 \mathbf{l 3}$.

Harpya Cuv., generic character and species, 207

Harriers «lescribed, 211.
Ilawfinch, its labits, 110. Goographical range, 11 I.

Fawk owls described, 218.

IInwks, synopsis of, 214.

lieliaptex Sw., sulogeneric character and species, 217.

llerwircus Sw., subtrencric cliaracter and species, 306 .

Homilophus Sw., sulygencric character and suecies, 309.

Il'mipolius, its pugnacity. 167.

Homiuterys Sw, subgeneric character and species. 242.

llermit birds, their halits, 254.

Herons, symosis of, 353. Described, 3:3. Their clsaracters, habits, and geographical distrilution, 172.

llimantopus Briss., 75. Cimeric chiracter, 360. Sulvgeneric charactor and species, $3 i i l$.

llimudinida, 151. lamily character and symopsis, 339. Sire Swallow8.

IIrundo Lin., gencric claracter and species, in.

Ioney buzands described, 211 .

lloney guides, synopsis of, 325 .

Honeysuckers, symopsis of, 325. 'Their liabits and afinltirs, 142. Divisions, 142. Remarks on the circle, 144. Their characters, habits, and analogies, 144.

llooked-billed cuckows, symopsis of, 322 .

Houpoes, synopsis of, 331. Thexir characters, habits, allimicies, and geograplical distribution, 143.

lormbill cuckows, sjonnesis of. 324.

Hornbills, syuopsis of, 298. Their attinities, 93 . Habits and 500. graphleal range, 94 Their structure and habits conymurt with those al the motanst, 14 I.

Horned owis deseribed, 217.

flumming-birds, 33 . Synopsis of 330. Aflinities, geographical range, characters, and divioions. 147.

Iyliota Sin., 8. Sulugeneric thisracter and species, $20^{\circ} 0$.

Itylophilus Tcm., 43. Subgeneris cluaracter ind speeics, 2.17 .

Ilypepetes Fig., sulygeneric cha. ricter and species, $22 \%$.

llyreus sho.g generie charater ind spectes, 296.

\section{I.}

Itis Antiq.. generic character and

species, 356 .
Ibises, synopsis of, 356. 'Their

VoIs. 11 . 
habits, strueture, and geographical distribution, 179 .

loycter Yieill., generic character and spucies, 209.

Icterla Vicill, 21. 24. Generic churacter and spocios, 225.

Icteria polyglotta, habits and character, 21 .

Icterinx, ty. Subfanily character and synopsis, 273. See Hanguests.

Icterus Cuv, generic character and species, 274 .

Ictunia Vicill., generic, character and species, 214.

Impeyals pheisunt, its plumage, 166 .

Importan, its familiarity, 21 .

Indian grouse, $16 \%$.

Indicator $L c^{\prime}$ "ikllint. gencric character and species, 325 .

Indietotorine, sulbunily character aud synopsis, 325.

Insessores, syuupsis of the genera of, 218.

löri scapuluris, plumage of, 19. Hahits of, 20 .

Irena Ilursf:, subgeneric character and species, 237.

Irena puello, 22. 36 .

Ispida $S w .$, subgeneric character and spectes, $\mathbf{3 3 6}$.

Ixos of Temininck, remarks ou, 23.

\section{J.}

Jacamars, their habits, 154.

Jacanas, their characters and habits, 178. Geographical distribution, 179.

Jager lescribed, 373.

Jamalı doscribed, 357.

Jays, synopsis of, 26.1 .

Jora, subgeneric character and sleecies, 227 .

K.

Kingfishers, synopsis of, 331. Their characters and habits, 153. Kinglusiters, 154.

King tyrant, 7 .

Kites, synopsis of, $20 \%$.

Kitta, 25.

kiwi described, $34 \%$.

\section{L.}

I.agouts Willegh., suhgeneric claracter and species, 343.
Lampornis $S w ., 148$. Generic character and species, 330 .

Lamprotis $s w .$, its plumage, 119. subgeneric character and species, $2 \bowtie 3$.

Lamprotile $S w^{\prime} .$. generic character and specius, 336 .

Lamprotorniva, 99. Subfamily character and synupsis, 270. See Grakles.

Lamiprotornis $T$ 'm., generic character and siperies. 271.

Laniada, 3. Family character aud syonpsis, 2 \&. Sec Shrikes.

Laniaux, 4. Subfamily charanter ind synopsis, 21\%. Sec True shrikes.

Lanifisuma, 73 .

Linnius Lin,, 11-14. 44. Generie charicter and species, 21s.

Lanius Laroline1sis cumpared with Orpheus polyglottus, 34 .

Lanins collurio, 1.

Lapwing deserlbed, 362.

Laride, 184. 105. Sublamily charactir and synopsls, 372. See Gulls.

I tark finch described, 259.

Larks, their character, 125. Synopsis of, 24l.

Larus, Limo, Igf. Gencric character and species, 373 .

Lathria Sw. generic character and species, 255 .

Leiotirix Sw., its characters, 71. Generic character and species, $24 \%$.

Leiotrichanx, 71. Subfamily charucter and sylupssis, 249.

Leistes V'ig., generie character and species, 275 .

Leptoglossa Sz', generic charzeter and species, 327 .

Leptonyx $S w$, generic charuter and speries, 230 :

Leptolophus Su. generic character and species, 305 .

Leptorytnchis Sim., generic character and species, 330.

Leptosoinus Fieillo, generic charater and species, 333 .

Lejutostoma ive., 161. Generie character and species. 325.

Leptostomina, snbiamily charaeter and sjnopisis. 324.

Leptotila sus., sulogenerit: cha. racter and speetics, 349 .

Lepturus Swl, its characters. 86. subgeneric tharuter and species, 259.

Lesser tyrant shrikes, plumage of, 5 .

Lessonia St.. generic character and species, 24 .

tessonia erythronotus, 41. 
Lestris Ill., 196. Generic character and species, 373 .

Lenconerpes $S^{r} w .$, subgeneric character and specics, $\$ 10$.

Leucophrys Su., subgetieric character thnd spucies, $2 \leq 7$.

Leucopygit Sw., subgeneric that racter and species, 2*5.

Leucusticte si. submennric character and specios, 281.

Licmet is 1 agl., renerle character and species, $30 \%$.

Limusa briss., generic character and speries, 360 .

Iinaria Brixs.., generic character and species, tsi. Situgeneric charactior and spexcies, 281 .

Linnets descrlhed, 231 .

Litcle auk, 142.

Little tyrants described, 225.

Lochmia S $t$-, generic claracter and specius, 320.

Lucust-euters, 6 in.

Loggerheadal shrike compared with the American moeking-hird, 31.

Long-tails, 189.

Long-billed cuckows, synopsts of, 324.

Long-legged chatterers, 71 .

Lonis-legged thrushes, is. 33. Their character 8 fnd habits, 22. Their rescinblance to tlie tyrant shrikes, 36.

Long-tailed locust-euter, 66 .

Iong-tailed tit, $\mathbf{4 3 .}$

Long-winged swillts of India, their characters, 162.

Longshanks, 176 .

Laphocerus Sto.s subgeneric character and species, 343.

Lophophorus Twm, genoric character and spedes, 312.

Lophorina Vieill., goneric charac. ter tunl sutcies, 332 .

Lophorynchus $\$$ sw.4 sulygeneric chatacter and species, 3ts.

Lophotes Iess., generic character and species, 213.

Lorianx, sublimily charactur and synopsis, 303.

Lories, synopsis of, 303 .

Loriets, synulsis of, 304.

Lorius Siriss., generic charicter and spueles, $30 \cdot 1$.

Loxia Lin., goncric character and species, 245 .

Loxia angolensis, 111.

lunet describel, $2: 0$.

Lypornix IVagl, subgeneric character and species, 334.

Lyre-tail, 164.

L.rurus $S w$, subgeneric character and species, 343.
M.

Macaws, syuopsis of, 299.

Machitus Cuv., suhgeneric claracter and specles, 3iil.

Makrocircinat, subtamily character and synopsls, 292.

Blacrodircus lieill., generic character and specles, 299.

Macrodiptery Sw, subguteric character and species, 339 .

Matcronyx sw., generle character itnd specists, 293 .

Macrunyx Capensis, 125.

Mlacropter yx Sw., 152. Subgener!c character and species, 340.

Mikropygin Sw., subgeneric chilritct tir and species, a 48 .

Mingrie described, $26 \%$.

Malno birds, their habits, character, and geographical lange, 110.

Matizers, synopsis of, 175 .

Malucolophus Sim., generie character, 3ts. Subrenerte rbaracter and species, $3 \%$. Its chatructors, 135.

Mialaronotus Sw.. 30. Generic character aul species, 220. Character of, 1\%.

Mabutorynchus Sto., sulggeneric charactor and suecios, 360 .

Malurus Vitill., G2. Generic character and species, 211. Subgeneric charister and species, 242.

Mamakins, synopsis of, 253. Their chiranters and habits, 76.

Mariots, 99.

Manorina Ficill, generic charactor and speries, 327 .

Marici Le'ach, gencric character and species, $36 \%$.

Mlarine dncks, their babits, 189. Genera, 184.

Marylimis yeliow-throat, 54.

Mlegalophus Su.; 82. Gencric eharacter and species, 257 .

Megalotes, name camcelled, 125.

Megonodina, family character und synopsis, 350 .

Mogatyodlus Gains, lfit. Subgeneric character and species, 351 .

Megastoma Sro, subgenerte chariwter and specles 225 .

Meiglyptes, Sw., subgencric character itnd species, 309.

Melinerpes $S 20$. , generic chiracter and species, 310 . Subgeneric character and species, 310 . Its characters, 135.

Molisoma Su"., generic character and species, 221. 
Meleagris Lim., subgeneric character and species, 341.

Meleagris ocellata, I65.

Meliphaga Levoir, xeueric character, 33ts. Sinhgeneric character and speciss, 320 .

Meliphrgitas, 142. Family character and synopsis, 8uin. Sice Honeysuckers.

Melithreptes Fitill., gemeric character and spectes. $32 \%$.

Melizophilas leruch, sulugeneric chareteter and species, 242 .

Melophus Su., suhgeneric character and species, 290.

Menura Shaw. Iris. Its hablts, 165. Generic charanter and species, 350 .

Merginidie, suhfamily character and synupsis. 3\%\%.

Mergatisers, synopsis of, 369 .

Mergulis, 192.

Mergus Lim., gencrle character and species, $30 \%$.

Meropida, la\%. Fanily cliaracter and synopsis, 332 . Siee IBeeeateris.

Merops Lin., gemeric character and species, 333 .

Merops apiaster, 150.

Mernla fillugh., 2t. fiencric claracter and piccies, got?

Merulide, 3\%. lamily character and syuopsis, ext6. General characters of $17.5 \mathrm{w}$.

Merulina, 17, 13. 24. Subfamily character and Bynopsis, gijl.

Metopia Siv, 7i. Subgeneric character and species, $25 t$.

Microglosus Geoti, generic character alud species, sut.

Microprogon Tems. subgeneric character and ijuecieg, 311 .

Microus Sit., 19. (iveleric character and spectics, 226 .

Migniotle of Let Vaillant, 8f.

Miliaria Sw. subgeneric charac. ter and species, cyyo.

Milvulis Sw., subgencric sharacter and spectes, $2: 5$.

Milvus Amiq.. generic character and spectes, 211.

Mnintilta fikill., In. 45. Subgeneric character and species, 245. see Crecjung warlolers.

Mniotilta varis, it charaeters, 48 , 49. Affinity with 1)mnecola rum ficauda, 50 .

Nocking-biril, 24.

Molothrus Sis., gencric character and specics, 976 .

Molotlirus nectris, 102.

Monacha Ihursf. \& V'g., 63. 82. Generic chntacter and Epecies,
257. Its characters and analogies, 83.

Monacha chrysomela, 83.

Mouscha telascophthalmus, 83 .

Monassa Vivill, 1.24. Subyeneric character and species, 33 .

Mormon $1 / 2$., generic character and species, 570 .

Motacilla Lin., 40. Generic character and epecics, 448 .

Motacillina, 89. Sntlanily clitracter and synopsis, 24\%. Soe Wagtails.

Mother Cary's ehickens, $19 \%$.

Motmots, their structurcand habits compared with those of the tulcals and lornbills, 1t. 1 .

Muscicapa Lin., 30. Generic character and species, 259 subgclleric cliaracter and species, 210. It characters and divisions, 84.

Muscicapa Dinps, 46.

Museicapa grisola, 8\%.

Muscocapa leucocilla, 90 .

Ifuscicanida, 5, -8. Family claructer and s) nopsis, 254. Sec Flycatchers.

Muscicapina, 81. Subfamily cliaracter and sjuopsis, $6 \pi$. See IIy-catchers.

Mnscipeti Cuc., 84. Subgeneric character and sirecies, 200 .

Muscovy duek, 18?.

Musophaga Isart, generio character and species, 297 .

Musopliagida, 126. Family tharacter and synonsis, 295. Sux: Plantain-f'aters.

Musopllagina, subfamily character and synopsis, gat.

Myeteria Lin., lit. Sulsgeneric ehatrateter and species, 3.j.j.

Myïugra llorsf. \&" Vik., 8t. Sub getreric eloaracter and species, L्रे०.

Myociucla Stu., subgencric character snd species gizo.

Myoplonus $T e m$, generic charatcter and species, 23 I. Analogries of, $25-31$. Jumage of, 25.

Myothera IIl., gencrir cliaracter, 209 Subgencric character, 250). Aftinities of, 27 . Aualogies of, 28-31. Charactors, plumage, and hobits of, 95,960

Myotherinze, 18. 94. Subfamily character and synopsis, zeng. 'Their strong reserublance to the Sylviaux, 69.

Myrafra llorsf, slbugeneric character and species, 192.

Myzomel7, IIorkf. \& rig., gencric charieter and species, 328. 
N.

Nanodes Hor.f. \& Tig., generic character and species, :3i)s.

Natatores, 183. Synu characters and babita, 184. I'amilies, 181, A salugies, 184.

Nauclerus $/$ is, guteric charater and species, 2109.

Nectar birds, bill of, 14ti. Geographical distribution, $14 \mathrm{t}$.

Nectarinia, $I h$, gelseric cluracter aud specice, 3.30 .

Nemosia l'zicill, gencric character and specics, 285 . It characters, 190.

Neophron Snu., genaric character and species, got.

Nicobar pigeon, 165.

Night herous descrihal, 354 .

Nightingale, 63.7

Nightingale warblers, their habits, 63.

Nightingales,synopsis ol, 240. Their haunts atmi food, $3^{4}$.

Nightjars, synopsis of, 338.

Vilaus Sw, 12, 1.3. Geuterie chnracter and biecles, 219.

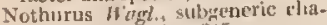
racter and syecics, $\$ 45$.

Nucitraga brisf, subfumily character aud sprecics, $\$ 6,3$.

Numenits liriss. 17\%. Generic cligracter and succies, 362.

Numida, renoric charucter and species, $34 \%$

Nutcracker described, 243.

Nuthatch, 131.

Nuthatcles, symopsis of, 317. Their listinctive characters, 131.

Nycthemerus $\$ w$, stogeneric character and sprecies, 34].

Nyctia Sul., geberic claaraeter and species, 217 .

Nyetiarden Sin. subgencric uharacters ani species, 354.

Nyctibius Iusnb., subgeneric character and specics, 339.

Nyctiornis Sw., 153. Generic character and species, 533.

Nyctipeics Siv, gencric character and species, 218.

O.

Ocypterus Cu., 8. Generic character amal species, $00 \%$.

Odontopliorus ficill, generic character and species, 343 .

CEdicnemus, 176. (ieneric character and kpecies, 365.

CEna Sclly, sutgeneric character and sycries, 329
Oidemia Flem, generic character and species, 368 .

Oper-bill, 174.

Opisthocomus Hefm, generic character and species, 325 . Its characters and habits, 163 .

Oriental J'itte, 30 .

Orioles, synopsis of, 286. Affinities and analogies of, 21 . 'Their strong rescmblance to the cater. jillar-cukthing slirikes, 35.

Oriolinte, 32 . Subtanily character and synopsis, ost. Sec Orioles.

Oriolus Lin., generic chracter and spceies, 237. Its analogy to Monacha, 83.

Orjolus galbula, 21 .

Oriolus paradisus, 20.

Orplueus Sw. 24, Generic charac. ter and species, 232.

Orplicus polyglottus compared with Imius Carolinensis, 34.

Ortilioa Mer. subgencric daracter and species, $35 \%$

Orthongx Tem, Ift. Generic character and species, 321.

Orthotomus Hor:f., geweric charactic and species, $2+1$.

Orthotomus longirostris, 62 .

Ortygis IIl. getueric character atuu species, 843 .

Ortyx ster., subgeneric cliarat. ter and greeies, 345 .

Ostriches, lis. Synopsis of, $34 \%$.

otis Lin., generic character and species, $5+5$.

Otus Antig., subgencric character ald spexies, 217 .

Ourax Cot., subgencric character and syecies, s52.

Oyster-cateluers, their babits and geograplicil distribution, 175.

Owts, syunsis of, 210 .

Oxpeckerts, synopsis of, 390. Their distinctive charucters, 131.

Oxyfouhus St., gencric character and species, 322 .

Oxyuotus $S_{2 w}, 7$. Generic charac. ter and spocies, 223.

Oxyrynchus Tem., 136. Generic character and species, 312.

oxystomus Sw., generic character and species, 270 .

Oxyurus Sio., generic character and species, 313.

\section{P.}

Pachycephala $\$ w ., 72,73.77$. Generic character and species, 250.

Pachycephalina, 71 .

Pachyptila $I U$. , subgeneric cliarac- 
ter and speeics, 37. Bill of, 197.

Pachyrhynchus Spix, 91 . Generic character and species, 05.5

Palsenris Vig., githeric cliaracter and specics, suo.

Palamedia l.in., generie character and sprecies, S.3.

l'andion Sa\%, generic cliaracter and species, 207 .

Paradise bircts, synopils of, sint. Hahits, characters, geograluical diatribution, and aftinilies, $1+3$. Their true plitce, 97.

Paradise oriole, 37, 38.

Paradisen Sr., generie character and specties, 331 .

Paradisiade, 112. Suhfamily character and syisopsis, 331, Sce Pararlise biris.

Parasitic cuckows, synopsis of, 321.

Parasitic gulls, their characters, haljits, and geographical arrangement. I96.

Pardalotus $V_{i r i l l}, 72.76$. Generic character and snecics, 25.

Parianse, S9. Sulblanily character and synopsis, 24t. See Titmice.

Parisoma Śl, 4,3,4. Sulgeneric character and species, 446 .

Parotia Hith. generic eharacter and species, sis

Parra Lin, 178. Generic character and species, 357 .

Parrots, 13li. I'heir linbits, 137. Divisions, 187. Symopsis रf, 249.

Partritsge, synopsis of, st: Described, SH.

Parus Lin, 12. 42 Generic character and spocies, 216 . Subgeneric: character and species, 24\%. Its close rescmblance to Egithalus, 57.

Parus and Sylvicola, their distinctive characters, $4 i$,

Parus liarmieus, th?

Parus candatus, is

Parus furcatus, 72 .

Passerella Siw, gencric character and spucies, 258 .

Yastor Tem., generic character: and e[teries, gis. Bill of, 100. Locusts destroyed by, 100.

Pastor musicus, 99.

Pavo fins, generic chameter and species, 341 .

Pavonida, family character and synopsis, 340. Typical charicter, 165 .

Peacocks, 16ĩ. Syuopris of, S40.

Pelican described, 372 . Synopsis of, 371 .

Pelicanida, 184. 199. Sulufamily character and synopsis, ST]. See Pelieans.
Pelicans, their characters, habits, and geographical distribution, 193. Synopsis of, st।

Pelicanus lin, gencric claracte: and speries, $37 \%$.

Pellorneum Stw, generic charactez and sprecies, $2 \mathrm{~s}$.

Penelope Lin, 163. Subgeneric character and zpecies, 350.

Penguins, 199. Thicir habits, analogies, and geographical distribution, 193.

Perchers, symopsis of, 218. How comected with the Rasores, 10n).

Perdix Rriss., generic rharacter, S41. Subgeneric character and species, $3+4$.

Peristera, Stt., generie eharacter and species, $\$ 49$.

Pernis Cut, general cluaracter and species, 211 .

Perspicilla, Stw., 90, Generic character and species, 257.

Petit l'ierre, alplication of the niame to the vetrel, 1.17 .

Petrels diescribed, 373. Their characters, habits, and geogrmphical distriburion, 169.

Petrocincla, rig., 24. Generic eharitcter and speeies, 230

Petroicu, (i,j.

Petroica licolor, 66.

l'etroica Lathanoi, its affinities and phimage, $6^{7}$.

retroïca multicolor, its plumage, fî.

Petrophila, Sw., suhgenerie character and species. 232.

Pezoporus III, Reneric character and species, $\$ 05$

Phanicoplieus, bill of, 138.

Phanicorıis, 7.

Phathorris, $14 \%$.

Phaton Lin., 194. Subgeneric chararter and sicecies, $\$ 72$.

Phalaropes, 177.

Phalaropus Boriss., subgenoric character alld spercics, 360).

Phaleris Tem, generic character and species, 371 .

Phasianus Lim, generic character, 8:1. Subgeneric eharacter and spceics, 341 .

Pheasants, lffi. Synopsis of, 3z0.

Phibalurn Iteill., generic character and speries, 25 ?

Phihalura Aavirostris, 74.

Philedon CWv, generic eharacter and species, $30 \%$. It characters and labits, 145.

Plsilomela, 54.

Jhilometilue, 39. 63. Subfamily character and symopsis, 240.

Phonicerens, su., 7to. Generic. character and species, 253. 
Plomicophaus, Vieill., generic character and specics, 324.

Phonicoptering, subfamily character and syousis, ifit.

Phonicopterus $L i m .$, generic character and species, $36 t$.

Plonicormis Sw. subgeneric character and sirecies, 2.24.

Phonicurasio, fit. Fencric cha= racter and species, 240 .

Phoenicoptinte, 19k.

thonisoma, \$ru., generic character and species, 283 . Subgeneriv charicter alli species, 284.

Phothornis Siu., generic charaeter and species, 330 .

Phouygama Less, gencric character and species, 26 t.

Phosphia, 172 .

Phyllastreulus $S w_{3}$, generie cha. racter ant spheses, 228 . Origiti of the same, 19.

Phytotoma Mol., gencric character and species, 816 .

Phytotomina, subfamily character and synopsis, ger.

Pjapec of Senegal, 97.

Pica Briss, sulugeneric character and syexics, $20 \%$

Picianre, 1.5t. Subfinity character and 5ynousis, 305. See 'Irue woodpeck $2^{2}[\mathrm{~s}$.

Picidze, 199. 18\%. Family character and syllopsis, 305 . Sec Woodpeckers.

Picumnus $1 \mathrm{~cm}$, generic cliaracter and species, 311.

Picus Sw reneric cliaracter and species, st6. Its characters, 134.

Picus principalis, 193.

Pigeun goobe described, $36 \%$.

Pigeons, synopsis of, 346 . Their

characters, liahits, and georraphical distribution, 368 . Alialogies, 170 .

Pine-crecping warbler, its habits

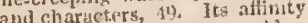
with the blacks and white warbler, 49.; and with the Vermivora, 50.

Pijillo I"icill., generic ehariteter and species, 28 it. Its charucters, 121. True place in a natural arrangement, 901 .

Pipra, Lin., generic eharacter and species, 254.

Pipra pareola, its nest, 76.

Piprina, 71. 76. Subtamily character and synopsis, 253. See Ma nakins.

Pithys Vieill., subgeneric character and species, 2,30 .
Pitta Tem., generic character and species, 2,0. Characters and plumage of, 25 . Analogies of, $28-31$.

Pitta cyanura, its plumage and analogy with Cinnyris Sencgar lensis, 39.

Pittix, 20.

Pitylus, variety in colour and size of the species of, 117.

Pitylus picatus, 117.

plint-eutters, syuopsis of, 226 .

PJ!ntuin-eaters, synopsis of, 205 . Their churacters and habits, 126 . llieir afinities, 127. Their feet, 127.

Plataica Lin., 174. Generic cluam racter and sufcies, S5.5.

Platycercinie, subfomily character and srntupsis, 304.

Platycercus Jorsf. \& Flg., generie tharater alit suecies, 30 .

Platylumbis Sis., 30. Subgenerio cliarsuler and species, 263 . Its asfuet and statiou, 16.

Platyrluchus Desw., subgeneric: claracter and epecics, 258 . Its characters, sô.

platystera fird. \& Sirlh., subgeneric chatacter and species, 259. Its thiracters, 86 .

Platystera lu',ata, 86 .

Platystera syntactyla, 87.

Platy

I']atystomis Sw, generic eloaratetrer and ypecies, 261 .

1) hat yurus is $w$, generic character and species, 310.

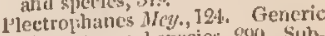
character and species, 290. Subgoneric character and species, (4)

Pectropterus Leach, analogy witl the liallita; 141. Gelueric charactel anil sperier, 365.

ploceus Chr., 111. Generic claa racter, 278, Subgencric charater and spocies, $27: 1$

r'otus fin., 195. Generic character ami specieg, s๊i 1 .

Plovers dascribed, 362. Their cha. ructers and habits, 174 .

Plyctolophine, subfamily chiraster and symopsis, 302.

Plyctoloyhus Vicill., generic cha. racter and species, 502 .

Pochards, 189.

Podargus Cut, generic phacter, 336. Proper, subgeneric cbaracter and sjecies, 338 .

P'odia, 192

Podiceps Lath, 198. Gencric character and species, 369. 
Podoa III, generic character and species, 370 .

I'ogonias $I I l$. generic character and species, 311 .

Poicephalus $s w$, generic cliarac. ter and species, sit) 1.

Polyborus ricill., geheric character and species, 209.

Polyplectron Tim., subreneric character and species, 341 .

Pomatorhinns, 18.8 .

l'orphyrio briss, generic charac. ter and species, $30 \%$.

Praticola Sw., generic character and species, 243 . Described, 363.

Pratincoles, 175:

Prinea, tio

Prionites $I I / .$, setteric character and species, 358 .

Prionites flatyrhyuchus, 1.41 .

Prionops Ficill, S. 30), (iencric character and sprecies, 220). Clia. racters and attinities of. 9. 11.

Prionol1s phomatus, babits of, 9.

I'rocellarin, generic character and specics, 373 .

Procnias $H_{0} f_{*}$, generic character and species, $25 i$.

Procnias ventralis, 74.

Proïthera $S_{i w}$, subgeneric charac. ter and species, 33 .

Promeropide, 112. Sinfamily character and synmusis, 331 . See 1 Loppoes.

Promerops, Briss., generic chae racter and suecites, 331 .

Promcrops Cilpensis, ins.

Proineroprs of New tiuinea, 143.

P'salurus Sw, stogeneric character and species, 334 )

l'sariand, sulsfamily character and specics, 205. Their charatters and geagraphical range, 90.

Psaris Cuo., 80. Bs. Generic cliaracter and succies, 255 . Its characters, 91. Its aunlogy to Miouaclia, 8\%.

Psarisosna, its characters, 81 .

Psarisonus, Sw., generic character and speries, fôl.

Psittatuda, 169, Ifwnily character and synopsis, 299. Set Parrots.

I'sittacins:, subfasily chirater and syuopeis, 300 .

Psittactlus $K u h$, generic character anul spcries, sos.

Psittacus Lin, gencric character and species, 301.

Psittirostra, $T_{e m}$, generic character and species, 294 .

Psophia Zihu., generic character and species, 351 .

Pterncles, Trm., sulugeneric cha. racter and species, $\$ 43$.
Pteroglossus $I I l .$. generic character and species, 299.

Pteroptuchus Kitflitz, generic character and species, $256^{\circ}$

Pteruthius $\$ w_{0}$, generic character and species, geg. Its characters, 71.

Ptilothlorus Stv, generic charac. ter aud species, 950.

Ptilogonys $S w, 6$, Generic character and species, 221 .

Ptilotejtus Sat, generic character and species, 323 .

Philorupus, generic character, 3\%. Subgencrlc cluaracter and species, St7. Its characters and geogranhical distribution, IfG.

Ptilonoryncbus $K u h t, 89$. Cieneric character and specles, 271 .

Ptilopachus Su., subgeneric character and species, sit

Ptilophyrus Sw.. gencric character and species, 840 .

rtoloris Sw. zeueric sharacter and specics, 331 .

Ptiloris paradiseus, 144.

Ptilostomus $S_{w .}$ yeneric character and species, 266 .

Ptilotis $S w .$, subgeneric character and species, 326 .

l'tiloturus $S w .$, generic character and species, 327.

Puff.birds, their liabits, 154.

Puftins, 13\%. Described, 30.

Putinus, $19 \%$.

Purjle water-hens, 179.

Pyrenestes Su., 110. Subgeneric character and species, 277.

Pyrgita Antig., 193. Gelleric charanter and species, 287.

Pyrrhodes Su., generic character and species, sils.

Pyrrhula, gencric character and species, 294.

Pyrrbulauda Smith, 125. Gcncric character and spetes, $29 \mathrm{k}$.

Pyrrhulina, 109. 125. Subfamily cliarneter and synopsis, 992. See Bulfinches.

Pytelia $S w$, subgeneric character and species, 280.

\section{2.}

Quails, 166. Described, 44.

Querula Vitill., 80. Generic character and species, 25:1. Its cha racters and habits, 91.

Querulina, 91. Sulfmily character alul synopsis, 255 .

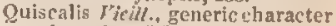
and species, 97 ? 
R.

Rail describer, 358 .

Rails, synopsis of, $85 \%$. Their characters aud habits, 178. Divisious, $17 R$.

Rallide, 172. Family character and synopsis, 357. See Rails.

Rallus $\operatorname{Lin}$. generic character and species, 358 .

Ramphasția:, 129. Jiamily character and syungsis, a98. See Toucans.

Ramphastos Lin., generic character and specics, 298 .

Ramphastos lucanus, 94.

liamphoris rizill., subgeneric character and species, 283.

Ramphopis coceinea, 119 .

Rantores, synopis of the genera

of, 205.
Rasores, $95,52,33.43$. Synupisis of, 340). 'Their utility to mail, 157 . Characters, 158. Habits and economy, 158. Analogles with hoofed quadrupedis, 1.59. Ilow conmeciel with the perehers, 160 . Divisions, 160 .

Rasorial birds, synopsis of, $\$ 40$.

Rasorial crows, 90 Their distinetive characters, 97.

IRasorial woodpeckers described, 308.

Razorbill, 192.

Recurvirostra Lin., 177. Subgencric character and spcries, 361.

lied hirds, 119.

Redbreast, 125 .

Red-eyed fiy-catcher, 75 .

Redstart, 6i.

Redstarts described, 240.

Redtails, their distinctive clonracters, 131.

lieed warblers, their haunts aui food, 39.

Regent wriole, 22.

Regulus liay, auhgenerie charaeter and speries, 210 .

Rhea Briss., subgeneric character and spocies, 346.

Rhipidura Horsf. \& Vig., 5\%. 82 Generic charactor and species. 257. Its characters, 84. 8\%.

Rifle-bird of New Holland, 144.

liver ducks, synopisis of, 566 . their habits, 180.

Rock manakin, 76 .

Rock-thrushes, 24. Described, 232.

Roller describeil, 333 .

Rupicola Briss., 76. Generic character and sjecies 253 .

liusticola, $17 \%$.
Rynchaa Cuy, subgencric character and species, 359.

Rynchops Lin., 195. Subgeneric character and species, 373 .

\section{S.}

Sand grouse described, 343.

Sandpipers, synopsis of, 359. Their characteristies, habits, and geographical distribution, 176 . Genera, 17 i

Sarcoramphus Dum, subgeneric chararter and species, 20.2.

Saurophagus Sw., \&. Generic character and species, 225.

Samrophagus sulphruratus, plumage of, 12.

Saurotliera, ricill., generic character and species, 224 . Bill of, $1 ; 8$.

Saxicola pileata, 65.

Saxicolina, 01. 59.64.

scansires, 3\%. Synopsis of, 298. lieet of, 199. Primary divisions, 1 (it).

Scaphidura, Swu, generic character and species, 272 .

Scaphidurine, 98. Subfamily character and synopsis, 272 . See Boat-tails.

Scherurus, Sw, generic character and species, 51 \%.

Scolecophagus, Su, generic character and species, 273.

scolopacidac, family character and synopsist 359 .

Scoloprax $\mathrm{Lin}$, 177. Generic charater, 359. Subgeneric claracter and species, 359 .

Scops Antiy, subgeneric charncter and splecies, 217.

Scojss owls described, 217.

Sicopus Briss., 174. Generic character and apecies, 355.

seortornis, Su, gencric character, 331. Subgeneric character ant species, 739.

Scoters, 180?

Scotiaptex Sau, subgencric character and species, 216.

Scotophilus Sw., subgeneric character and specics, 217.

Seythrops Iath., generic character and strecics, 299.

Sea ducks, synopsis of, 36 S. $^{\circ}$

Sea swallows, their characters, 10.5 .

Secretary described, 208.

Sedge warblers, their habits, 63 .

Seicercus, 84. Its characters, 89.

Seisura, Horsf. \& Vig., generic character and snecies, $250^{2}$. Its characters, 89. 
Sciurus Sw., subgeneric character and species, $24 \%$.

Seiurus aquaticus, its habits, 42.

Seiurus aurocapillus, 5.5, lts hobits, 4 ? .

Sericulus, generic character and species, 237.

Sericulus chrysorephatus, 22.

Seriloplıs Si., gelveric character and species, $26 \%$. Its characters, 81.

Scrisomus $S e n$, generic character and species, 203 .

Setophaga $\mathrm{Sw}_{.3}, 19.4 \%, 53$, generic character and species, g6t. It:s rank in the circle of the l'ariante considered, fol. Iis conneution with sylvicala, 58. See Fly. catching warblers.

Setophagz Canarensis, in.

Setophaga ruiniata, its julumage, 6.

Setophaga picta, $5 \mathrm{k}$. Its filumage, 67.

Setophaga rubra, 55 .

Setophaga ritisilla, 60 .

Shearwater pefrel, 197.

Sheldrake, 189 .

Shoveller, 189 Short-footed thrushes, synopsis
of, 226 .

Short-legged tirushes, aftinities and analogics of, 18 .

Shrike-crow's descrilued, $26 \% 3$.

Shrikes, 3. Wxternal cliaricters of, 4. 1)ivisions of, 4 . Ie nark on the aberrunt, subfamilles of 8. Analogies of, 14. Synopsis of, 218 .

Siatia, 6.5.

Silky chatterers, synopsis of, 210.

Sitta Lin., generic character aud species, 318.

Slttasomus So., subpcneric cha. racter and species, 314 .

Slttelin S\%o, gencric claturacter and species, 317.

Sittina, 131. Sublaubily character and syllupsis, 317 .

Skimuners, bill of, 194. IIalits, 195.

Snipes, 176. Synopsis or, 3.4.

Somateria Learh, getuerie character and specics, $36 \mathrm{~K}$.

Sparrow deserihei, 287.

Sparrow owl described, 214

Sparrows, 123.

spermestes Su., subgenoric character and species, $2 \times 1$.

Spernophara $S \%$, stogeneric cliaracter aud species, 277.

SpermophilaSw., snbgencric clariteter and species, 294.

Sphenurus Sw., subgtieric character and species, 349.

Splatëtus I'itill., grnoric character and species, $21 \%$.
Spoonbills, 174.

Spotted manakins, their characters and haluits, 76 .

Spur-wing described, 357 .

Siquatarola Cu*., guneric character and splecics, 362 .

Starlings, synnţsis of 200 . Their habits, characters, and prineijyat gromps, 98.

Slema $\operatorname{Lin}, 19 n$. Generio character, 372 . Suligeneric cliaracter and species, $37 ?$

Storks, tlieir utility to man, 174.

Stome-chats, their liasnts and food.

39. Thelr characters and habits, 61. Git.

Strcpstlas IIl., 17.5. Generic character and species, $\% 1$.

Strigide, tamily character and synopsis, 216.

Strix Lim., generic character. 216. Sntggeneric charmeter and specles, 216 .

Struthio, Antiq., generic character. 34.5. Subreneris character and species, 31 \%

Struthlonidie, fimily charncter and synopsis, 3.15. Thelr habits, 163.

Sturnclla tirill., generic flaracter and sperics, 276 .

Sturmella collaris. inot.

Sturnida, 98 . Family character and synopsis, 260. See Starlings.

sturnine. 9\%. Sibfiully charactor and synopsis, 209 . Sce True Starlings.

Sturuus $I_{i n,}$, generic character and speties, 260 .

Sultana describrd, 357.

Summer duclis, 10 ?.

Sunbirds, their characters, affinitles, and goographical distribution, 14.j. Sjzopsis of, $32 \%$.

Snetorial birds, synopsis of, 325 .

Surnla Dum., generic charicter and specics, 218.

Swallow chntterers, syuopsis of, 251.

Swallow plovers, 115.

Swallow rollers, 152

Swallow woodpeckers described, 135.

Swallows, their characters, 151. Synopsis of, 339 .

Swans, synopsis of, 364. Described, 364 .

Swift slirikes, 8 .

Swiminers, synopsis of, 364 .

Sylvia Latham, 44. 6L. Generic ciaracter and species, 212. Subgoneric eharacter and species, 242.

Sylvia galuctntes, 64 .

Sylvia velat $\mathrm{k}, 54$. 
Sylviada, 31. 38. Union of the aberrant groups, 67. See Warblers.

Sylviana, 39, 61. Subfamily character and syuopsis, 241. "Theis strong reseruhlauce to the Myotherina, $b 9$.

Sylvicola $S w, 42.45$, Its divistons, 45. Its subgenera, how distluguished from those at 1'arus, 45. Its connection with Setophatgi, 8. Generic character and sjecies, 244 . Sulveneric chimeter and species, 2.4 . Ser Titnice warblers.

sylvicola and Parus, their distinctive chiracters, 44

Sylvicola Americana, is, 59.

Sylyicola Camadensis, 59 .

Sivivicolit coronita, 59.

Sylvicolina, 80.

Syma Less., subgrneric charneter and species, 335.

Symplectes Sin., subgeneric character and speches, 279.

Symallix is Tieill., generic character and species, 316.

Synopsis of a natural arrangement of birds, 201 .

System of nature, leading principles of, 1

\section{T.}

Tabularview of the analogies of the ant-thrushes with the perchers, 27 . ; witl the tonth-billew birds, 20 . with the bush-slirikes, 30 . with the subfamilies of the shrikes, 3t. : of their five ptithcipal divisious with the urimary orders of lisds, 3z. with the shrikes, 31. with the honeysuckers, 37 : of the ant-tlurushes with the uriters of lirds, by.; among the orders of hirds, the tribes of fuerrlers, anil the subfamilies of that warthlers, (c), ; of the tribes of the porthers and thu" sublamilies of the: warblers, 6x.; of the finches and starlings, (WI).: of the sturlings with the crows, 105. कf the starlings with the perchers, 104. boween the wackers and perchets, 180 . amongst the salbrenera of Sylvicola, the gemeris of P'artiua, and the tribes of Insessores, 55 . of thr reuns Sylvicola, 5l.; of the shrikes, 14, of the Natatores, isi, : of rasoriallirds with hoofed quiuirulents, 150.

Tabulitr vice of the subfamilies of the Sylvladx, 40 ; ol the sub- genera of Todis, the tribes of perchers, and the orders of birds, 88. ; of the subgenera of Sylvicolis and Parus, 52.

Tarhturomus $1 / L$, 175. Geperic eharnetrr, 363 . Sulggeneric character and sriecies, 363 .

Tachyjetes Ficill, generic character and species, $3 i 1$.

Tachyphonus Fitill., subgeneric character and speries, 284.

Tadorna licach, generie chancter and spccies, :37.

Tamatia cuv. l's4. Generic charicter, 334, Subgencrif character and species, 33 !.

Tanbers, synopsis of, $2 \times 1$. Canse of diversity in their hills, 116 . Their aftivities, 137. Aberrant, 120. Their haljits, cliaracters, and geograplieal range, 113. Intermal arrangentut of the groul?. 114.

Tamagrelta Sw, subuenerie chot racter and speries, $246 \%$

Tamarina, lok, Subfomily character and syuopsis, 281 . She T:mnagers.

Taisaliula, 172. Family charicter and synopsis, 356. Slec libises.

Tantalus Lin., generic charater alld species, 356 .

Tanysiptera $l$ ig. subgencrie character amel species, $335^{\circ}$.

Tardivola $S w$, generie charucter and speeles, 281.

Teloghonus $5 w .12$ Cicnerie clinincter and species, 219.

T'elofihnus collinis, 13.

Telofinonus leueogrammicus, 13.

relojhonus lezngirostris, tik.

Temuurus Sw, subgeneric charactor and species, 337 .

Tenuirostres, 33. 142. Syno[sis of, 32\%. See Homey-suchers.

Teuhrodurais Sw. 8. Ceneric charicter and gpecles, 221.

Terus, thelr charncters, 195. Deserihed, 372,

Totrac Lin., generic characer. 343. Subgencric character and s]erjus, $34: 3$.

Tolraniste, famil character and syuofsis, 313 . Their charaters. liahits, and geomraphicul distribution, 116 .

Thalassilroma Jig., 197. Surgeneric character and spectes, 373.

Thalissites $S_{w,}$ subgeneric character aud specios, 372.

Thamnobia, 6 ต็.

Thamnonhitina, 4. Subfamily chnricter and synopsis, 220 , Ser: Hush shrikes. 
Thamnophilus Sw., 30. Generic character and species, 220 . Cliaracters of, 10.15 .

Thicklieads, synopsis of, 249 .

Thicklieided chatterer, its lialuits, 73.

Thick-knee described, 3ri.3.

Thick-kned bistarls, 176 .

Throstle, 24.

Thrush lamily deseribed, 17, Divisions of, I*.

'Thrushi's, synopsis of, 226.

Thryothurus $T$ zeill, gencric clasracter sud species, $31 \%$.

Tiaris Sim., II2. Generic eharacter and species, 2xi).

Ticlodroma $/ l l$, generic character and specles, 320 .

Tiger bitterns, 173. Deserlbed, 354.

Tigrisoun Su., 173. Sulbgeneric charicter aud specles, 3.y.

Timalia Joryf., subseneric character ind species, 23 i,

Timalia thoracica, 23.

Tinnamon described, 31.5 .

Tiunamous, their characters and habits, if $\mathrm{k}$.

Pitlarks, their charneters, $\mathbf{4 l}$.

Titmice, 13. 6s. Symopsis of, 244. Tlieir claracters and habits, 42. Their hamots and food, 39.

Tit-warlilers, their habits, 46 , Slmilarity of their habits to those of the wood-wartuler, tits, and Aly-catcliers, $\mathbf{4} 6$.

Todiramplius $L_{c} x^{\prime} s$, sulogenerie cliaracter and species, 335.

Todus $\not i m .$, goberie clurater and species, 2. Its audugies, 87. lts geograjuleal ranue, characters and hiluts, 85. It suligenera, 85. Its circle oxemplified, 87.

Todus regins, its character, 82.

Totunus Bichst., 177. Suturenerlc elialacter and specics, $3 ; 1$.

Toucan, 53.

Toucans, synopsls of, 291. Their character, hibits, and geographi cal distrlbution, 137. Divisions, 138. Their structure and habits compared with thuse of the motmots, 141.

Touraces birls, their food, 127. Habics and anatomical structure. 128.

Tree ducks deseribed, 365.

Tree-runucrs, synopsls of, 31.5.

Trichas $\$ 2 \%, 42,54,55.61$. Generic character and specios, 247 .

Trichas personatus, 54.

Trichas velati, 72.

Trichoglossus l'ig., generic character and species, 304.

Trjcopliorus Temm., 18. Origin of the name, 19. Generic character and species, 228.

Tringa Lin., subgeneric character and species, 360 .

Tringida, 172. See Saudpipers.

Tripsurus sw., subgeneric chnracter aul species, 311 .

Trochilide, It2. Family clitricter and synopsis, 330. See llumeming-birds.

Trochilis Axct, 147. Cieneric character and speries, 330 .

T'roglodytes $L$ in. generie charac= tor and specios, $3 \% 0$.

Troglodytina, 131. Subfamily charicter and synopsis, 319.

Trogon, generic clmanter and spetics, 337.

Trogonida, 1.7. Family character and symopsis, 337. See l'rogons.

Trogons, synojisis of, 337. Their place in the naturil arrangement, 155. Charueters and luabits, 15n. Affinity to else goatsuckers, 155. To the jucamars anil motmots, 156.

Tropic-lulrds, 194. Describet. 372.

'lrue crevpers, sytugpsis of, 312.

True crows. their hablts, 96 . Cie. nora remuved from, 97.

True curlews, 177 .

T'rut fileons described, 212.

True gerese, 91. Deseribed, 365.

'I'rue gulls, their charmeters, habits, and geograplical allstribution, 1916.

True nstrich descrilhed, 345.

True pelicaus, 193.

True pengtins, 193.

'True petrels, their habits and geographical distribution, 197.

'I'rue pigeons, sytropsis of. 297.

'l'rue plantain-eaters, synopsis of, 297.

I'rue rollers, 152.

'l'rue slirikes, 4. Habits of, 11. Synopsis of, 218.

T'rue starlings, their destructive character, gs. Haljits, 9?. Reserublance to crows, 100 .

True swifts, their cliaracters, 151.

True thrushes, I 2 , Syuopsis of 231. Characters of, 24.

True tyrant shrikes, labits of, 6 .

Truc wurblers, symopsls of, 211.

True woudpeckers, synojsis of

305. 'Ilicir characters, 131.

True wrens, their habits, and station in the natural system, 132.

Trumpeter er:une, $\mathbf{1 7 3}$

Tuited unlyer, 174.

Turkeys, 165.

Turnstume deseribed, 361. Origin of it 5 name, 175.

Turtle described, 349 . 
Turtur Selby, generic characters 349. Subgeneric character and species, 346.

Typical cliaterers, synopsis or, 252.

Typical creepers, their distinctive charact $r, 131$.

Typical cruws, synopsis $n f, 262$.

Typical ducks deseribed, 360 .

Typical owle doseribed, 216.

'lypical st:trlines, syoopsis of, 269 .

Typical tyrants seserlbeul, 225.

"lypical woadpeekers described, 305.

Tyrannine, 4. Subfamily character and symopsis, 224. Sce Tyrant shrikies.

Tyrammila Sw., 80. Cheneric clareter and speclis, 225.

'Tyramula amlulans, 6 .

Tyrannula, 5 .

Tyranuus fichll., goturic chatatter and species, 225 .

Tyrannus intrepidus, 7.

- yrant shrikes, 4. A flinitics of, 5 . 8. 15. Their resemblance to the long-legged thrushes, 36 . Sy* 130 os is of, 224.

\section{U.}

ITmber descrilhed, 35\%.

Upupa lim., grencric cliaracter and speciek, 331 .

Upupa lipops, 143.

[:ria Briss., 192. Ceneric charncter and spectes, 370 .

\section{V.}

Vanellus Priss., generic character and species, $3 ; 0$.

Vanga Buff: sthiteneric character and speries, efis. liemarks on the genus, 1 in.

Vanga destructor, luabits of, 16.

Vormivora Sin., 45 . Sintugeneric character and species, 245. Sies Wormecaters.

Vermivora pinus, its mode of leeding, 51 .

Vermivora solitarit, 50 .

vidua Cho., sulogeueric chararter and sjeries, $27 \mathrm{~s}$.

Yidua phmicoptera, 11 ?.

Vigursia sib., gemerle chiractor and species, 304 .

Viuagu Cav, subgencric character and species, 317 . Its characters, habits and geographical distribution, 16:5.

Violet platicin-sater, it sood, $12 f \%$.
Vireo Vieill., 72. Generic character and specics, 250 . Its characters, 73 .

Vireo favifrons, 73 .

Vireo ollvaceus, 73.

Viresina, subtamily character and synopsis, $24 y$.

Vultur lin., generic character and spacies, 2115.

Vultures, synopsis of, 205.

Vulturida, family character and syonopsis of, 205 .

\section{W.}

Waders, synopsis of, 353 . Their charactors and habits, 171. Finmilics, 172.

Wagtails, synopsis of, 217. Charaters and haloits, 40, Their liavints and fovd, 39.

Walking tyrants described, 225.

VVarblers, characters and habits of the family, "38. 'Talle of subfamilies, 40.

Whter-chats, synopsis of, 256 . "T'beir geographical range, characters, and habits, $\$, \%$. Of Brazil, plumage of, 5 .

Wattle crows, synopsis of, 205

Water-hen described, 358.

Winter-ouscls, characters of, 2.5 .

W cuvers, their habits, 111. Deseribed, 278 .

Wheatear, 65.5 .

Whlmbril, 176.

Whinchat, 65 .

White-eyed warlilers, their characters, 47. Analogy to the honeysuckers, $4 R$.

White-hended tody, 90. Habits of, 5.

White-rump, 65.

White-tluroated warbler, 64.

Widgeon deseribed, 360 .

Wilgeons, 189.

Villow wren, 61 .

Wiuter fauvette, 54.

Woodeneks, 176.

Woudperkers, symopsis of, 305. 'Their vluaracters and habits. 132. Allinitios, 133. Internal relations, 131.

Wiood wirblers, their liaunts and foorl, 3is.

Wood wren, 61.

Worm-caters, their habits, 45.

Wrens, synopsis of, 319, Their distinctive characters, 131.

\section{I.}

Yellow-throats, 54 
Ynambus, their characters and habits, 163 .

Yunx Lim, 136. Generic character and snecies, 311.

\section{Z.}

Tanclostomus SW., ceneric cliaracter and speciss, 323 .

Tanthomiza Sw ., subgeneric character and speries, 326 .
Zanthornis $C u v$, generic character and species, 274 .

Zenops III., generic character and species, 317.

Ziphoryuchus Su., subgeneric character and species, $3 ! 3$.

Zonotrichia sim., subgeneric character und species, 288.

Znsterops Horsf. Vig., 45. 61. Sulgencric character and species. 245 . See White-cyed walblers.

END OF THE SECOYD VOLLME.

\section{L.NBON :}

Printed by A. Sportswoone, New-Streetsquare. 
TIIF

\section{A B I N E T}

\section{OF \\ NATURAL HISTORY.}

CONDUCTEU BY TIE

REV. DIONYSIUS IARDNER, LL.D. F.R.S. L. \& E.

M.R.I.A. F.R.A.S. F.L.S. F.Y.S. Hon, F.C.P.S. \&c. \&c.

ASSISTED BY

FMINFN' SCIENTIFIC MEN.

ON

THF NATURAL HISTORY AND CLASSIFICATION

OF

B I R D S.

$\mathrm{BY}$

WILLIAM SWAINSON, A.C.G. F.R.S. VICE-PRESIDENT OF THE ORNITHOLGICAL SOCIETY, ETE.

VOI. II.

\section{LONDON:}

PRINTED TOR

LONGMAN, REES, ORME, BROWN, GREEN, \& LONGMAN, PATERNOSTER-ROW ; AND JOHN TAYIOOR, UPPER GOWER STREET. 
LoNDON :

Printed by A. SpotTiswoode,

New-Street-square. 



